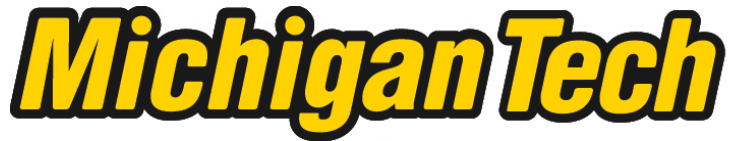 \\ Michigan Technological University Create the Future Digital Commons @ Michigan Tech
}

Dissertations, Master's Theses and Master's Reports - Open

Dissertations, Master's Theses and Master's

Reports

2012

\section{Cold-Start Emissions testing of Snowmobiles Using Ethanol and Gasoline}

Michael David Rittenour

Michigan Technological University

Follow this and additional works at: https://digitalcommons.mtu.edu/etds

Copyright 2012 Michael David Rittenour

\section{Recommended Citation}

Rittenour, Michael David, "Cold-Start Emissions testing of Snowmobiles Using Ethanol and Gasoline", Master's Thesis, Michigan Technological University, 2012.

https://doi.org/10.37099/mtu.dc.etds/488 


\title{
COLD-START EMISSIONS TESTING OF SNOWMOBILES USING ETHANOL AND GASOLINE
}

\author{
By \\ Michael David Rittenour

\begin{abstract}
A THESIS
Submitted in partial fulfillment of the requirements for the degree of MASTER OF SCIENCE

(Mechanical Engineering)
\end{abstract}

MICHIGAN TECHNOLOGICAL UNIVERSITY 2012

COPYRIGHT @ MICHAEL D RITTENOUR 2012 
This thesis, "Cold-Start Emissions Testing of Snowmobiles Using Ethanol and Gasoline," is hereby approved in partial fulfillment of the requirements for the Degree of MASTER OF SCIENCE IN MECHANICAL ENGINEERING.

Department of Mechanical Engineering-Engineering Mechanics

Signatures:

Thesis Co-Advisor

Dr. Scott A. Miers

Thesis Co-Advisor

Dr. Jason R. Blough

Department Chair

Dr. William W. Predebon

Date 


\section{Table of Contents}

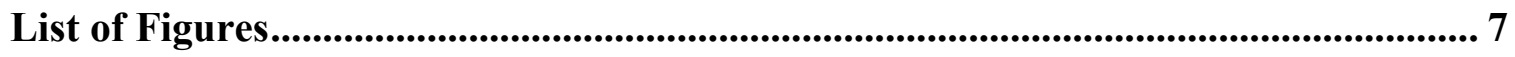

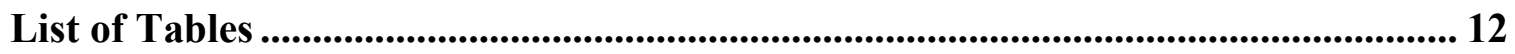

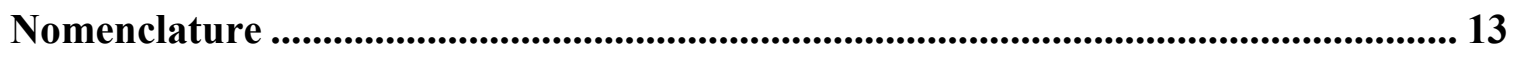

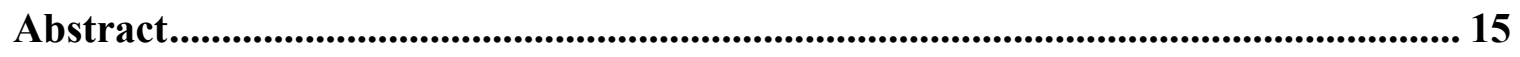

Chapter 1 Introduction......................................................................................... 17

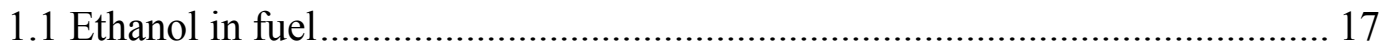

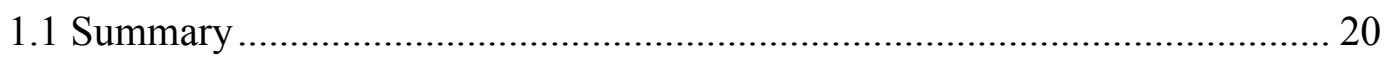

1.2 Research Goal and Objectives .......................................................... 20

Chapter 2 Background/Literature Review ................................................................... 22

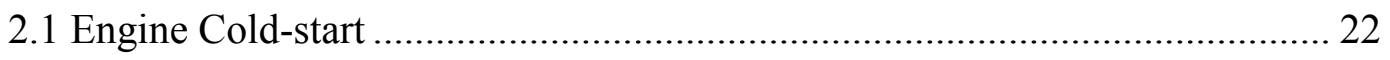

2.1.1 SAE J1635 AUG98 .............................................................. 22

2.1.2 Tsunooka 2007, SAE 2007-01-2036..................................... 23

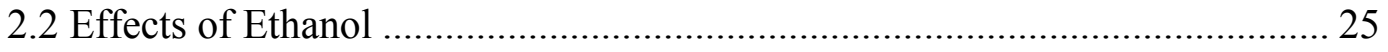

2.2.1 Knoll 2009, SAE 2009-01-2723 …......................................... 25

2.2.2 Bresenham 1999, SAE 1999-01-3345 ..................................... 27

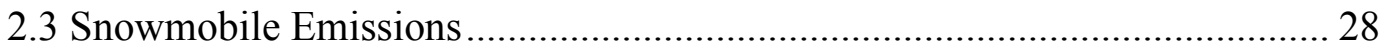

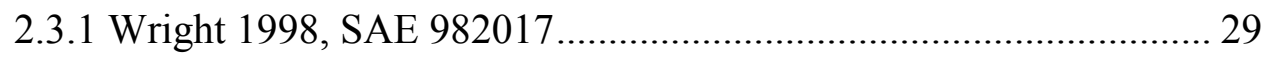

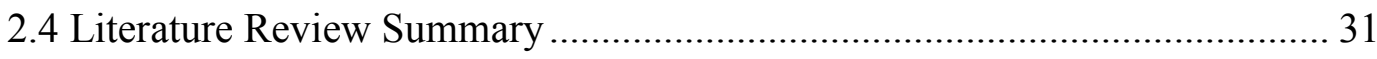

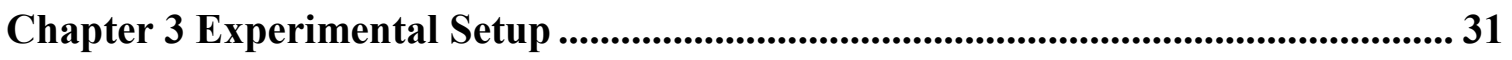

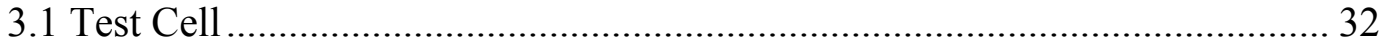

3.1.1 Cold-Start Trailer Layout..................................................... 32

3.1.2 Cooling Ductwork........................................................... 34 


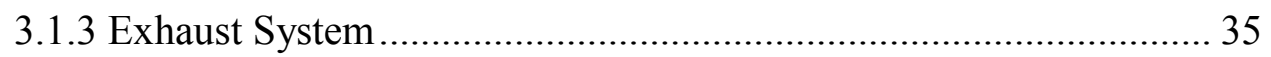

3.1.4 Emissions Sampling Setup............................................................ 37

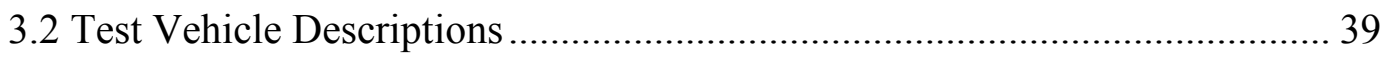

3.2.1 Yamaha FX Nytro RTX................................................................. 40

3.2.2 Ski-doo MX Z TNT 600 H.O. E-TEC ……………………………... 41

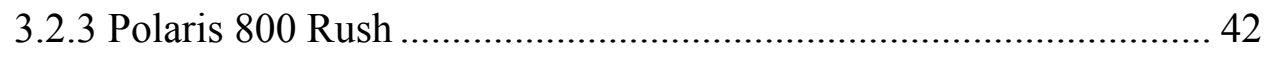

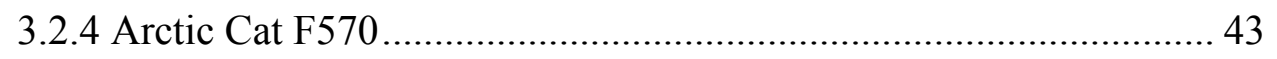

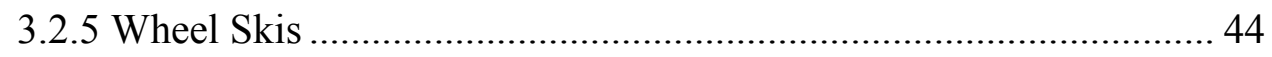

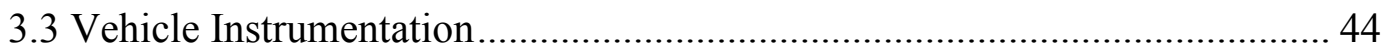

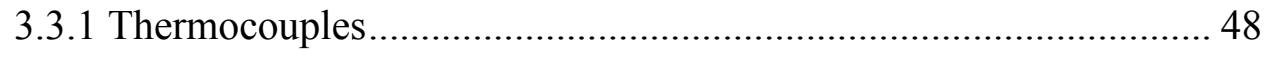

3.3.2 Optical Speed Sensor ..................................................................... 49

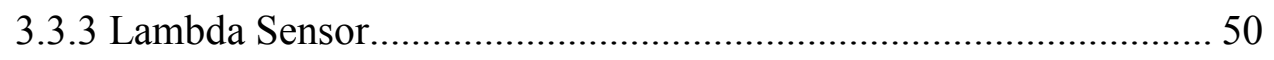

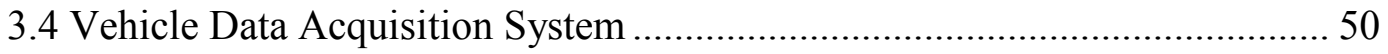

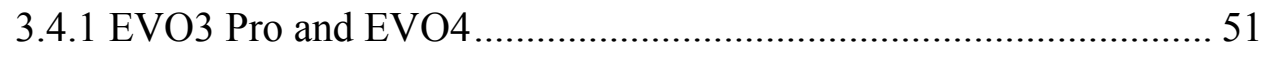

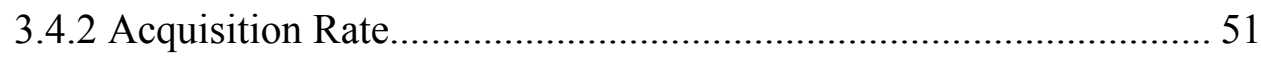

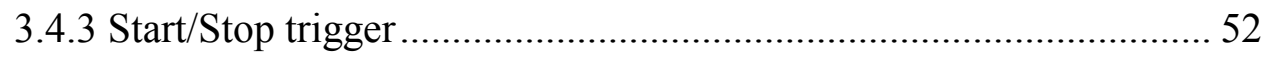

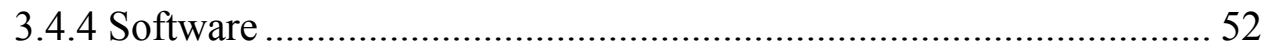

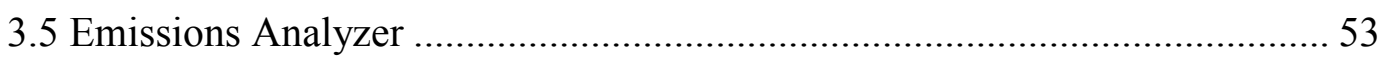

3.5.1 Flame Ionization Detector (Hydrocarbon Measurement) ................. 54

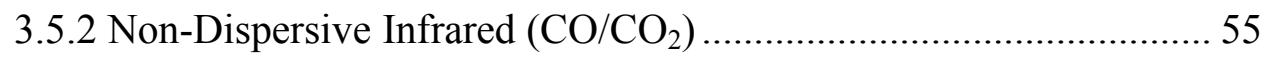

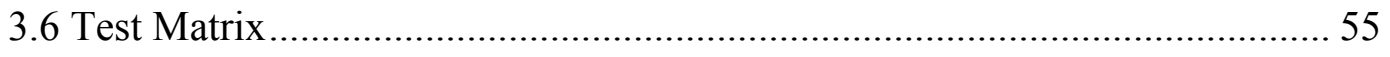

3.6.1 Temperatures and Fuels ................................................................ 56

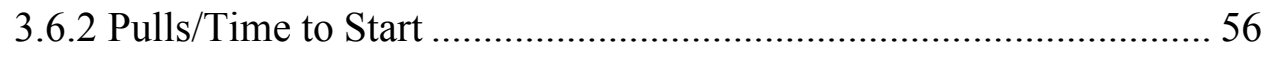


3.6.3 Other Recorded Parameters .......................................................... 57

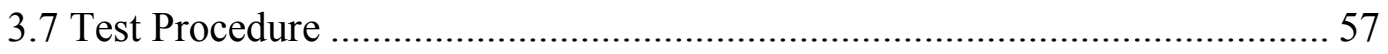

3.7.1 Engine Cleanout ........................................................................ 58

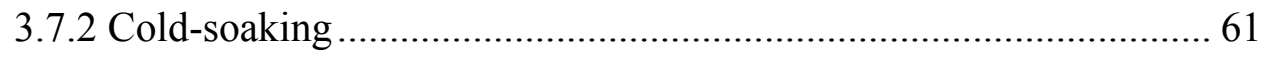

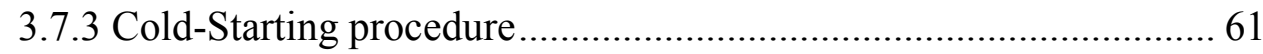

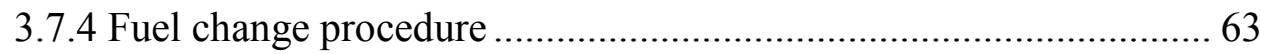

3.7.5 Complications and issues with Cold start testing ……..................... 64

Chapter 4 Results .......................................................................................................................... 67

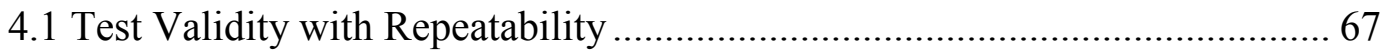

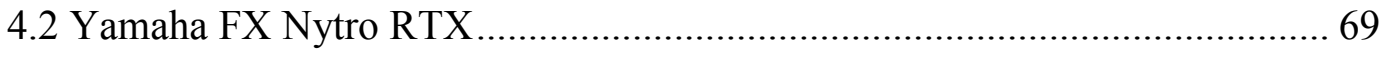

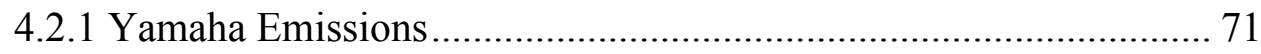

4.2.2 Yamaha Engine Data ..................................................................... 75

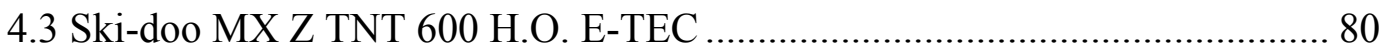

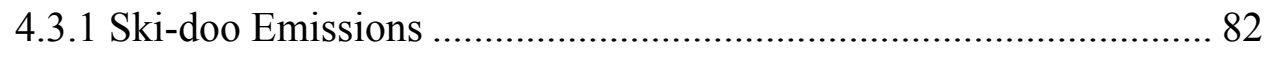

4.3.2 Ski-doo Engine Data ................................................................... 87

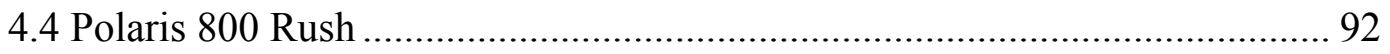

4.4.1 Polaris Emissions ........................................................................... 94

4.4.2 Polaris Engine Data........................................................................ 98

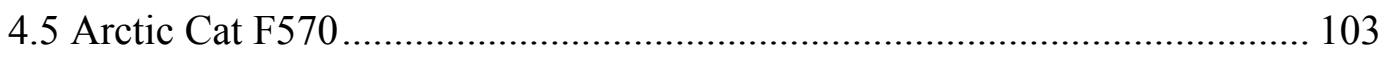

4.5.1 Arctic Cat Emissions.................................................................... 106

4.5.2 Arctic Cat Engine Data ............................................................... 111

Chapter 5 Conclusions and Future Work ......................................................................... 117

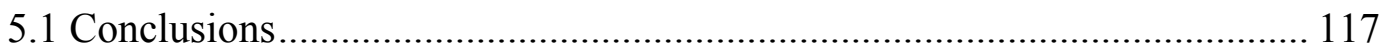




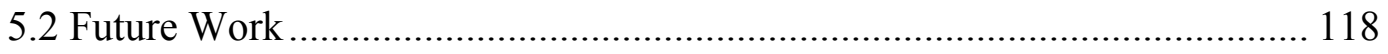

Bibliography ……................................................................................................................ 120

Appendix A ............................................................................................................................... 123

A.1 Note sheet and additional plots ............................................................ 123

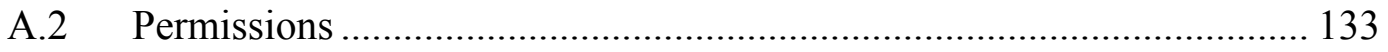




\section{List of Figures}

Figure 1.1: Petroleum production, net imports and consumption (US EIA October 2011)

Figure 1.2: Consumption of fuel in the transportation sector (US EIA October 2011)... 18

Figure 1.3: Usage of ethanol in millions of gallons (US EIA October 2011) .................. 19

Figure 2.1: Vehicle average percent change in composite emissions and fuel economy relative to E0 (Reprinted from SAE paper 2009-01-2723).................................. 26

Figure 3.1: Cold-start test cell trailer layout …………………….............................. 33

Figure 3.2: View from the back of test cell looking forward into the control room......... 33

Figure 3.3: Snowmobile ramp built for easy access in and out of test cell....................... 34

Figure 3.4: Cold air ductwork for test cell................................................................ 35

Figure 3.5: Example of how the engine exhaust was removed from the test cell............. 36

Figure 3.6: Exhaust duct fan and exhaust hose mounted in rear door of trailer ............... 36

Figure 3.7: Example of the emissions sampling probe located in the exhaust ................. 37

Figure 3.8: Semtech heated emissions sample line in test cell ....................................... 38

Figure 3.9: External heated filter with temperature control box....................................... 39

Figure 3.10: Yamaha FX Nytro RTX test snowmobile ..................................................... 41

Figure 3.11: Ski-doo MX Z TNT 600 H.O. E-TEC test snowmobile ............................... 42

Figure 3.12: Polaris 800 Rush test snowmobile.............................................................. 43

Figure 3.13: Arctic Cat F570 test snowmobile …………................................................. 43

Figure 3.14: Custom wheel skis installed .................................................................... 44

Figure 3.15: Data acquisition box placed on top of the hood of the Ski-doo ................... 45

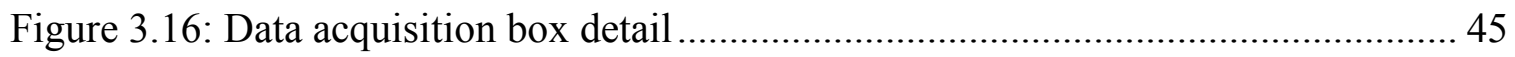


Figure 3.17: Thermocouple installed in exhaust and EGT clamp .................................. 48

Figure 3.18: Ring thermocouple installed on sparkplug................................................. 49

Figure 3.19: Optical speed sensor used to obtain speeds................................................ 50

Figure 3.20: EVO4 and EVO3 Pro Data loggers ............................................................ 51

Figure 3.21 Sensors Inc. Semtech-DS five-gas emissions analyzer ................................ 54

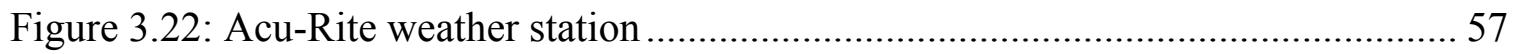

Figure 3.23: Satellite picture of parking lot where snowmobiles were cleaned out ......... 59

Figure 3.24: Example of Yamaha snowmobile using the track-stand .............................. 60

Figure 4.1: Yamaha E15 $-20^{\circ} \mathrm{F}$ individual tests and average of $\mathrm{CO}$ emissions............... 68

Figure 4.2: Yamaha E15 -20 ${ }^{\circ} \mathrm{F}$ individual tests and average of engine speed ................ 68

Figure 4.3: Percent change of Yamaha emissions when changing to E15 ...................... 69

Figure 4.4: Average Yamaha cold-start cranking time required for the engine to start ... 70

Figure 4.5: Average Yamaha cold-start $\mathrm{CO}_{2}$ emissions.................................................. 71

Figure 4.6: Average Yamaha cold-start CO emissions................................................... 72

Figure 4.7: Average Yamaha cold-start THC emissions ............................................... 73

Figure 4.8: Average Yamaha cold-start $\mathrm{O}_{2}$ emissions .................................................... 74

Figure 4.9: Average Yamaha cold-start air-to-fuel ratios ................................................ 74

Figure 4.10: Percent change of Yamaha engine parameters when fuel changed to E15 .. 76

Figure 4.11: Average Yamaha cold-start test cell temperatures ...................................... 77

Figure 4.12: Average Yamaha cold-start engine speeds.................................................. 78

Figure 4.13: Average Yamaha cold-start engine coolant hot temperatures...................... 79

Figure 4.14: Average Yamaha cold-start center exhaust gas temperatures ...................... 79

Figure 4.15: Percent change of Ski-doo emissions when fuel changed to E15 ................ 80 
Figure 4.16: Average Ski-doo cold-start number of pulls required to start the engine .... 82

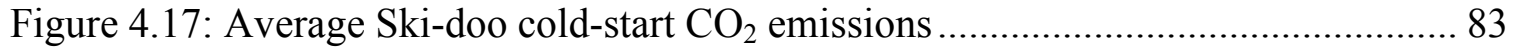

Figure 4.18: Average Ski-doo cold-start CO emissions ........................................... 84

Figure 4.19: Average Ski-doo cold-start THC emissions ........................................ 85

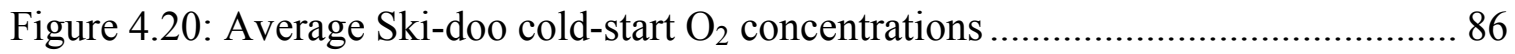

Figure 4.21: Average Ski-doo cold-start air to fuel ratios ........................................ 86

Figure 4.22: Percent change of Ski-doo engine parameters when fuel changed to E15... 88

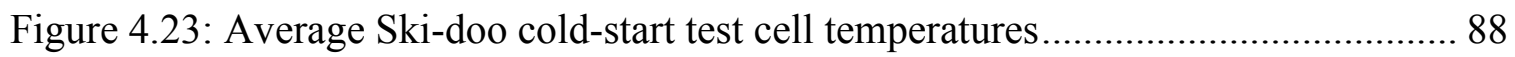

Figure 4.24: Average Ski-doo cold-start engine speeds ............................................ 89

Figure 4.25: Average Ski-doo cold-start engine coolant temperatures.......................... 90

Figure 4.26: Average Ski-doo cold-start MAG head temperatures ............................. 91

Figure 4.27: Average Ski-doo cold-start MAG exhaust gas temperatures ..................... 92

Figure 4.28: Percent change of Polaris emissions when changing to E15..................... 94

Figure 4.29: Average Polaris cold-start number of pulls required to start engine........... 94

Figure 4.30: Average Polaris cold-start CO2 emissions ............................................ 95

Figure 4.31: Average Polaris CO cold-start emissions............................................. 96

Figure 4.32: Average Polaris cold-start THC emissions ......................................... 96

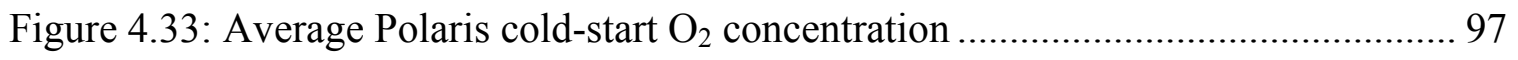

Figure 4.34: Average Polaris cold-start air to fuel ratios ......................................... 98

Figure 4.35: Percent change of Polaris engine parameters when changing to E15 ........ 100

Figure 4.36: Average Polaris cold-start test cell temperature .................................... 100

Figure 4.37: Average Polaris cold-start engine speeds ......................................... 101

Figure 4.38: Average Polaris cold-start coolant temperatures ................................... 102 
Figure 4.39: Average Polaris cold-start MAG exhaust gas temperatures...................... 103

Figure 4.40: Percent change of Arctic Cat emissions when changing to E15 ............... 104

Figure 4.41: Average Arctic Cat cold-start number of pulls required to start engine .... 104

Figure 4.42: Average Arctic Cat cold-start $\mathrm{CO}_{2}$ emissions ...................................... 107

Figure 4.43: Average Arctic Cat cold-start CO emissions ...................................... 108

Figure 4.44: Average Arctic Cat cold-start THC emissions ..................................... 109

Figure 4.45: Average Arctic Cat cold-start $\mathrm{O}_{2}$ concentrations .................................. 110

Figure 4.46: Average Arctic Cat cold-start air-to-fuel ratios.................................... 110

Figure 4.47: Percent change of Arctic Cat engine parameters when changing to E15... 112

Figure 4.48: Average Arctic Cat cold-start test cell temperatures............................... 112

Figure 4.49: Average Arctic Cat cold-start engine speed ....................................... 113

Figure 4.50: Average Arctic Cat cold-start air temperatures .................................... 114

Figure 4.51: Average Arctic Cat cold-start PTO head temperatures ........................... 115

Figure 4.52: Average Arctic Cat cold-start PTO exhaust gas temperatures .................. 116

Figure 4.53: Average Arctic Cat cold-start MAG exhaust gas temperatures ................ 116

Figure A.1: Sample note sheet from cold-start testing .......................................... 123

Figure A.2: Average Yamaha cold-start NO emissions.......................................... 124

Figure A.3: Average Yamaha cold-start relative humidity...................................... 124

Figure A.4: Average Yamaha cold-start ambient pressures .................................... 124

Figure A.5: Average Yamaha cold-start lambda ................................................... 125

Figure A.6: Average Yamaha cold-start DAQ system battery voltage ....................... 125

Figure A.7: Average Yamaha cold-start MAG exhaust gas temperatures..................... 125

Figure A.8: Average Yamaha cold-start PTO exhaust gas temperatures ...................... 126 
Figure A.9: Average Ski-doo cold-start relative humidity .......................................... 126

Figure A.10: Average Ski-doo cold-start ambient pressures ......................................... 126

Figure A.11: Average Ski-doo cold-start lambda .......................................................... 127

Figure A.12: Average Ski-doo cold-start DAQ battery voltages.................................... 127

Figure A.13: Average Ski-doo cold-start cold engine coolant temperatures .................. 127

Figure A.14: Average Ski-doo cold-start PTO head temperatures ................................ 128

Figure A.15: Average Ski-doo cold-start PTO exhaust gas temperatures ....................... 128

Figure A.16: Average Polaris cold-start relative humidity .............................................. 128

Figure A.17: Average Polaris cold-start ambient pressures........................................... 129

Figure A.18: Average Polaris cold-start Lambda ……….............................................. 129

Figure A.19: Average Polaris cold-start DAQ battery voltages ..................................... 129

Figure A.20: Average Polaris cold-start engine coolant cold temperatures .................... 130

Figure A.21: Average Polaris cold-start PTO exhaust gas temperatures........................ 130

Figure A.22: Average Arctic Cat cold-start relative humidity …………………........... 130

Figure A.23: Average Arctic Cat cold-start ambient pressures ...................................... 131

Figure A.24: Average Arctic Cat cold-start lambda ………………………………...... 131

Figure A.25: Average Arctic Cat cold-start DAQ system battery voltages.................... 131

Figure A.26: Average Arctic Cat cold-start fan air temperature in ................................ 132

Figure A.27: Average Arctic Cat cold-start MAG head temperatures ........................... 132 


\section{List of Tables}

Table 2.1: Summary of emissions results with small engines ......................................... 28

Table 2.2: Comparison of J1088 test cycle and proposed snowmobile test cycle............ 29

Table 3.1: Snowmobile Test Vehicle Information............................................................ 40

Table 3.2: Yamaha FX Nytro RTX Instrumentation ....................................................... 46

Table 3.3: Ski-doo MX Z TNT Instrumentation........................................................... 46

Table 3.4: Polaris 800 Rush Instrumentation.................................................................. 47

Table 3.5: Arctic Cat F570 Instrumentation ................................................................. 47

Table 3.6: Semtech DS emissions analyzer measurement ranges, accuracy and resolution 54

Table 3.7: Test matrix of cold-start tests of each snowmobile ......................................... 56

Table 3.8: Quad blend gas used to span the Semtech DS before and after each test....... 62

Table 4.1: Yamaha average results of emissions and starting data................................. 70

Table 4.2: Average engine data of Yamaha ................................................................ 75

Table 4.3: Ski-doo average results of emissions and starting data ................................. 81

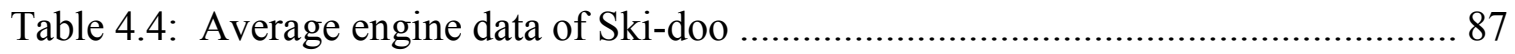

Table 4.5: Average Polaris results of emissions and starting data................................... 93

Table 4.6: Average engine data for Polaris.................................................................. 99

Table 4.7: Average Arctic Cat cold-start results of emissions and starting data ........... 105

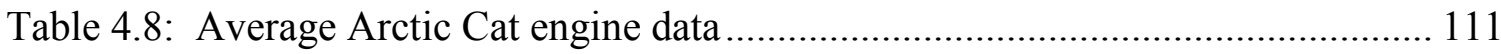




\title{
Nomenclature
}

\author{
AFR: Air to Fuel Ratio \\ CO: Carbon Monoxide \\ $\mathrm{CO}_{2}$ : Carbon Dioxide \\ DI: Direct injection
}

E0: Pure Gasoline

E15: $15 \%$ ethanol and $85 \%$ gasoline by volume

ECU: Engine Control Unit

EGT: Exhaust Gas Temperature

EIA: Energy Information Administration

EISA: Energy Independence and Security Act

EMF: Electro-Magnetic Force

EPA: Environmental Protection Agency

FFV: Flexible Fuel Vehicle

HC: Hydrocarbons

LTFT: Long Term Fuel Trim

MAG: Magneto

MAP: Manifold Absolute Pressure

NMHC: Non-Methane Hydrocarbons 
NMOG: Non-Methane Organic Gas

NO: Nitric Oxide

NOx: Nitric Oxides

NREL: National Renewable Energy Laboratory

$\mathrm{O}_{2}$ : Oxygen

PTO: Power Take-off

RPM: Rotations per Minute

RVP: Reid Vapor Pressure

$\mathrm{R}+\mathrm{M} / 2$ : Anti- Knock Index

SAE: Society of Automotive Engineers

THC: Total Hydrocarbons

US: United States

${ }^{\circ} \mathrm{C}$ : Degrees Celsius

${ }^{\circ} \mathrm{F}$ : Degrees Fahrenheit 


\begin{abstract}
Increasing prices for fuel with depletion and instability in foreign oil imports has driven the importance for using alternative and renewable fuels. The alternative fuels such as ethanol, methanol, butyl alcohol, and natural gas are of interest to be used to relieve some of the dependence on oil for transportation. The renewable fuel, ethanol which is made from the sugars of corn, has been used widely in fuel for vehicles in the United States because of its unique qualities. As with any renewable fuel, ethanol has many advantages but also has disadvantages. Cold startability of engines is one area of concern when using ethanol blended fuel.
\end{abstract}

This research was focused on the cold startability of snowmobiles at ambient temperatures of $20^{\circ} \mathrm{F}, 0{ }^{\circ} \mathrm{F}$, and $-20^{\circ} \mathrm{F}$. The tests were performed in a modified 48 foot refrigerated trailer which was retrofitted for the purpose of cold-start tests. Pure gasoline (E0) was used as a baseline test. A splash blended ethanol and gasoline mixture (E15, $15 \%$ ethanol and $85 \%$ gasoline by volume) was then tested and compared to the E0 fuel. Four different types of snowmobiles were used for the testing including a Yamaha FX Nytro RTX four-stroke, Ski-doo MX Z TNT 600 E-TEC direct injected two stroke, Polaris 800 Rush semi-direct injected two-stroke, and an Arctic Cat F570 carbureted twostroke. All of the snowmobiles operate on open loop systems which means there was no compensation for the change in fuel properties. Emissions were sampled using a Sensors Inc. Semtech DS five gas emissions analyzer and engine data was recoded using AIM Racing Data Power EVO3 Pro and EVO4 systems.

The recorded raw exhaust emissions included carbon monoxide (CO), carbon dioxide $\left(\mathrm{CO}_{2}\right)$, total hydrocarbons (THC), and oxygen $\left(\mathrm{O}_{2}\right)$. To help explain the trends in the emissions data, engine parameters were also recorded. The EVO equipment was installed on each vehicle to record the following parameters: engine speed, exhaust gas temperature, head temperature, coolant temperature, and test cell air temperature. At least three consistent tests to ensure repeatability were taken at each fuel and temperature combination so a total of 18 valid tests were taken on each snowmobile. The 
snowmobiles were run at operating temperature to clear any excess fuel in the engine crankcase before each cold-start test.

The trends from switching from E0 to E15 were different for each snowmobile as they all employ different engine technologies. The Yamaha snowmobile (four-stroke EFI) achieved higher levels of $\mathrm{CO}_{2}$ with lower $\mathrm{CO}$ and THC emissions on E15. Engine speeds were fairly consistent between fuels but the average engine speeds were increased as the temperatures decreased. The average exhaust gas temperature increased from 1.3$1.8 \%$ for the E15 compared to E0 due to enleanment.

For the Ski-doo snowmobile (direct injected two-stroke) only slight differences were noted when switching from E0 to E15. This could possibly be due to the lean of stoichiometric operation of the engine at idle. The $\mathrm{CO}_{2}$ emissions decreased slightly at 20 ${ }^{\circ} \mathrm{F}$ and $0{ }^{\circ} \mathrm{F}$ for E15 fuel with a small difference at $-20^{\circ} \mathrm{F}$. Almost no change in $\mathrm{CO}$ or THC emissions was noted for all temperatures. The only significant difference in the engine data observed was the exhaust gas temperature which decreased with E15.

The Polaris snowmobile (semi-direct injected two-stroke) had similar raw exhaust emissions for each of the two fuels. This was probably due to changing a resistor when using E15 which changed the fuel map for an ethanol mixture (E10 vs. E0). This snowmobile operates at a rich condition which caused the engine to emit higher values of $\mathrm{CO}$ than $\mathrm{CO}_{2}$ along with exceeding the THC analyzer range at idle. The engine parameters and emissions did not increase or decrease significantly with decreasing temperature. The average idle engine speed did increase as the ambient temperature decreased.

The Arctic Cat snowmobile (carbureted two-stroke) was equipped with a choke lever to assist cold-starts. The choke was operated in the same manor for both fuels. Lower levels of CO emissions with E15 fuel were observed yet the THC emissions exceeded the analyzer range. The engine had a slightly lower speed with E15. 


\section{Chapter 1 Introduction}

\subsection{Ethanol in fuel}

The idea of using ethanol as a fuel has been around for many years. In fact, in the late 1800's, Otto Cycle was the first combustion engine designed to use alcohol and gasoline and then Ford Motor company's first car, the Model T, also used an ethanol corn alcohol gasoline for its fuel. Ever since the 1980's, ethanol has been added to gasoline to enhance the octane number. In the last 20 years several Acts and amendments have been put into place to encourage more use of ethanol ("Ethanol Fuel History" 2009). According to the Energy Independence and Security Act, by 2015, 15 billion gallons of renewable fuel, including ethanol, needs to be used (H.R. 6 2007) to help become secure and independent from foreign oil. Currently the ethanol content in gasoline is up to 10 percent by volume but to meet the requirements of this act, the ethanol content in gasoline might need to be increased to possibly E15 or even E20. This means that all vehicles would be running this fuel including cars, trucks, snowmobiles, and other recreational vehicles. Some of the older engine technology that operates on an open-loop control system, such as in most recreational vehicles, cannot compensate for the fuel change. The effects of the blend of ethanol and gasoline on recreational vehicles and small engines are not known.

The fuel used in the transportation sector accounted for a major part of how much petroleum is consumed in the United States. Since the 1950's, the United States has not been able to produce enough petroleum to support its needs so a large part of the petroleum consumed has to be imported. Figure 1.1 and Figure 1.2 are plots of data from the US Energy Information Administration (EIA) Report in 2011 which shows the amount of imports needed and how much the transportation sector depends on these imports. Some of the imports come from areas in the Middle East where a lot of oil is readily available. These countries that the oil is imported from can be economically unstable and being so dependent on foreign oil is not a smart economical decision. 


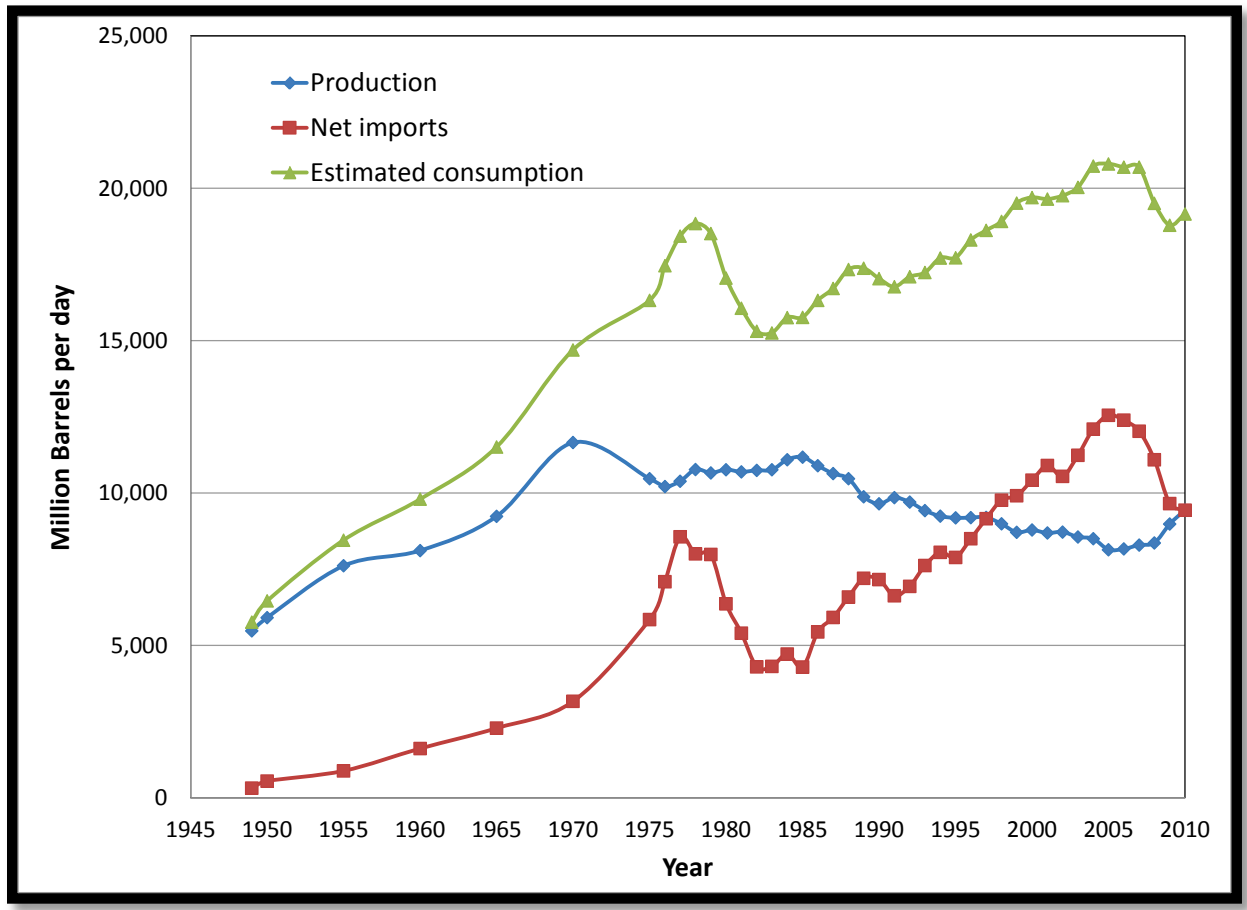

Figure 1.1: Petroleum production, net imports and consumption (US EIA October 2011)

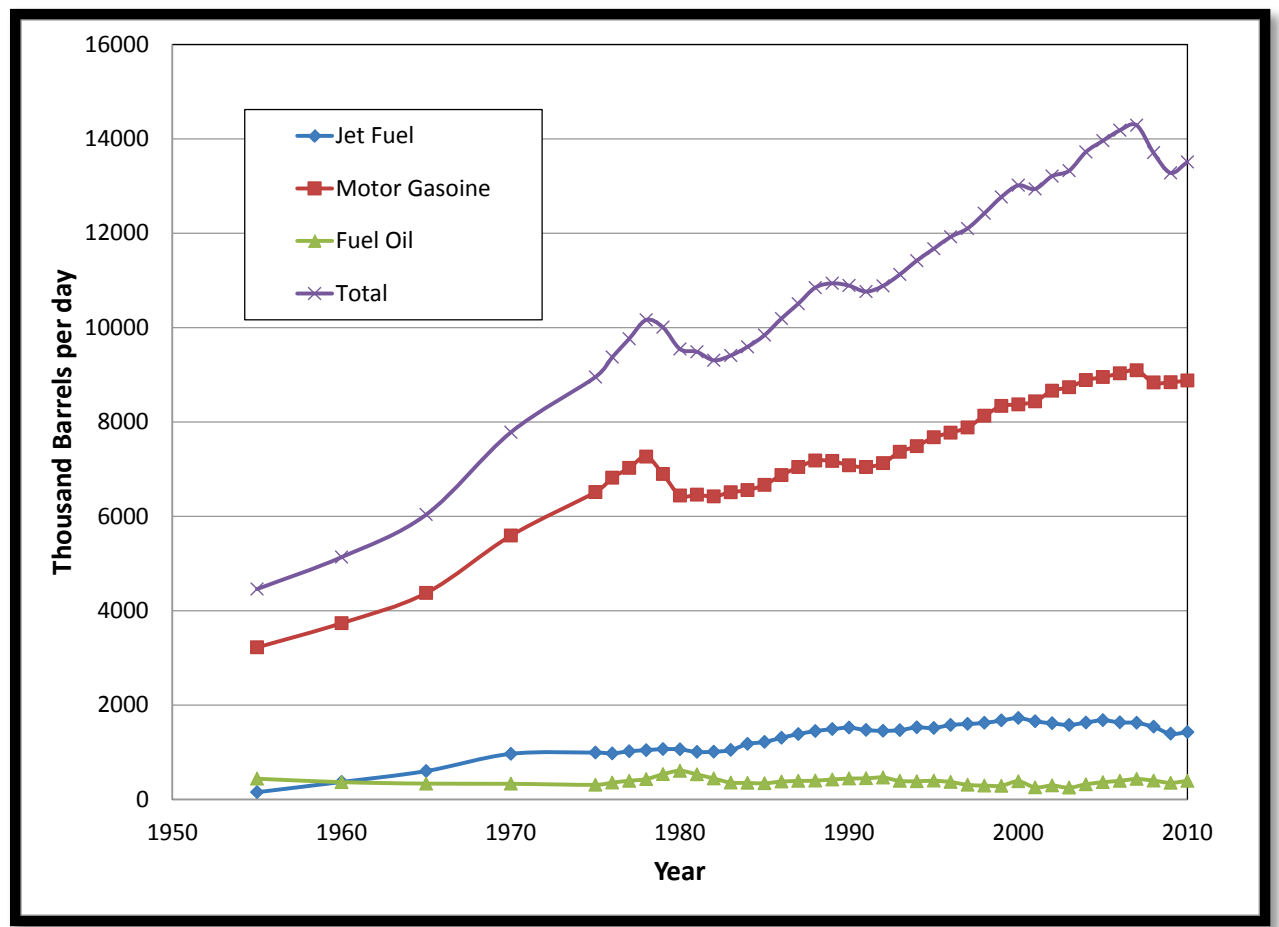

Figure 1.2: Consumption of fuel in the transportation sector (US EIA October 2011) 
The transportation sector has a very large dependence on gasoline and with the instability of foreign imports, finding alternative ways to fuel engines is needed. Adding ethanol into fuel decreases the dependency on foreign oil. Finding different forms of renewable energy has been the focus of the US government because of the decreasing amount of fossil fuels available on earth. Figure 1.3 shows the last 30 years of the usage of ethanol. The increase in usage is to meet the standards of 15 billion gallons by 2015 . If the government regulates the content of ethanol in gasoline to reach the 15 billion gallons, legacy utility engines and recreational vehicles will have to run the higher content ethanol. There has been very little research done in the area of utility (small engines) and recreational vehicle areas so the effects of higher ethanol blends are unknown and should be researched to gain more information about emissions and durability.

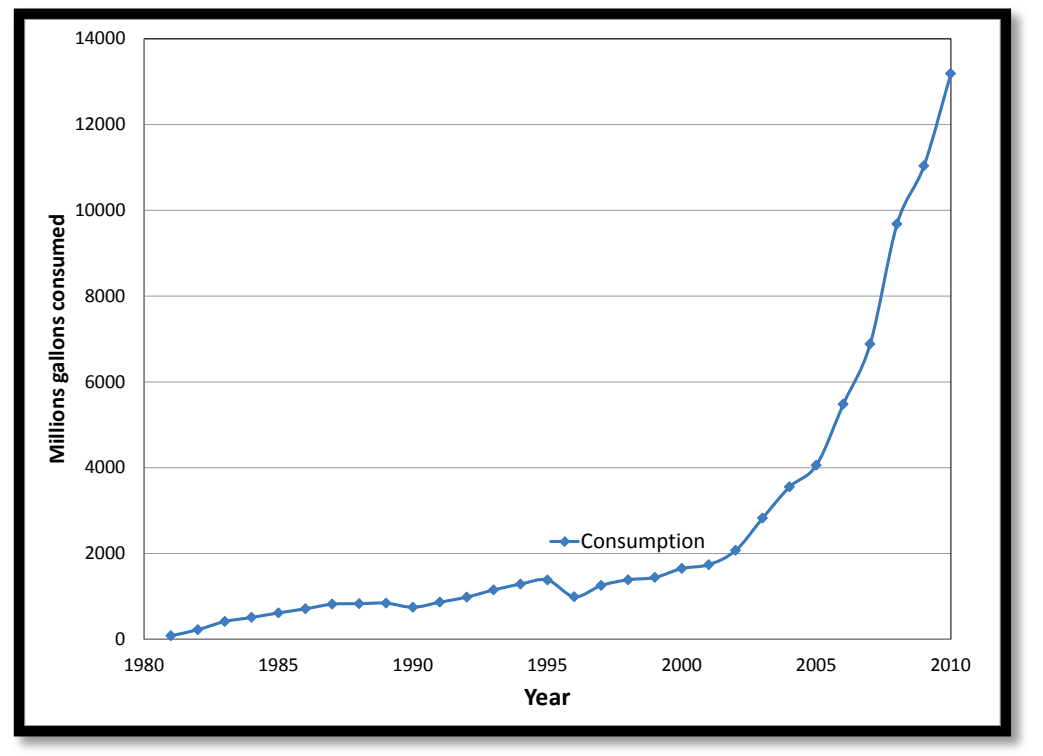

Figure 1.3: Usage of ethanol in millions of gallons (US EIA October 2011)

The use of ethanol in fuel could have a positive effect on emissions. This positive effect may be accomplished because of the improved fuel conversion efficiency with increasing ethanol content. However, ethanol produces challenges concerning the coldstartability and emissions during cold-starts. These challenges are because of the high latent heat of vaporization which is $840 \mathrm{~kJ} / \mathrm{kg}$ when compared to $350 \mathrm{~kJ} / \mathrm{kg}$ for pure 
gasoline (Heywood, 1988). This high latent heat of vaporization makes it very difficult to vaporize the fuel inside of the cylinder and becomes more of an issue at colder temperatures (Heywood 1988). In most of the newer engines with engine control units (ECU), calibrations can be modified by implementing a lambda sensor in the exhaust which provides feedback to the ECU and can change the fuel delivery to maintain the same air to fuel ratio. However with older vehicles that do not operate on closed loop systems or do not have an ECU, they could have issues with changing of fuel from what it was originally intended with cold-start and durability. The normal operation of an engine for cold-starts is to over-fuel to get enough fuel to evaporate to combust and the un-burned fuel will pass through the engine and be expelled in the exhaust. These emissions during a cold-start test could be improved or worsened by the addition of ethanol. Most production recreational vehicles do not use a catalyst and therefore, emissions have higher values when compared to road vehicles.

\subsection{Summary}

Right now there is no procedure or regulation for snowmobile and recreational vehicles emissions during cold-start processes as there is with on-road vehicles. If regulations for reducing emissions continue, there could very well be a limit placed on the recreational vehicle cold-start emissions. This thesis on cold-start emissions could be helpful in producing a procedure and preliminary definition for recreational vehicle cold start tests. There is also a need for more information on the effects of ethanol on small/recreational engines and this data provides some insight on this topic.

\subsection{Research Goal and Objectives}

The goal of this research was to evaluate the effects of E15 during the cold-start process of snowmobiles. This was accomplished by instrumenting and testing four current production snowmobiles using one snowmobile from each major manufacturer. Emissions data including carbon monoxide $(\mathrm{CO})$, carbon dioxide $\left(\mathrm{CO}_{2}\right)$, hydrocarbons (THC) and oxygen $\left(\mathrm{O}_{2}\right)$ were recorded and was supplemented with engine data. The emissions were measured using a Semtech DS emissions analyzer and engine parameters 
were recorded using individual onboard EVO systems which were capable of acquiring speeds, temperatures, accelerations, run time, and GPS location. Through the data acquired, trends were observed and analyzed comparing the two different fuels at colder than ambient temperatures.

Instrumenting the snowmobiles for cold-start testing and retrofitting the cold cell for the snowmobiles was the first objective accomplished. Procedures for testing and changing fuels also needed to be generated to ensure consistency. After the data was collected, the information needed to be organized and displayed to ensure that the coldstart data taken was valid and the next fuel could be tested. 


\section{Chapter 2 Background/Literature Review}

In this this section, papers that were reviewed to gain a better knowledge on the subject are summarized. The main topics these papers focused on were ethanol, coldstarting and snowmobiles.

\subsection{Engine Cold-start}

This section focuses on cold startability of engines.

\subsubsection{SAE J1635 AUG98}

The SAE standard J1635 from August 1998 is a cold-start and drivability procedure recommended for motor vehicles. This document is a recommended practice which also defines drivability defects with a rating system. The vehicles being tested should be soaked at the specified temperature for a given amount of time until the engine coolant becomes stable. The evaluations may be affected by the ambient temperature, pressure and type of fuel used. This document also lists other specifications for performing the drivability part such as road conditions, wind speed limit, and transmission settings.

In the J1635 document, it does not list any references for the paper simply because there have been no publications that concern a procedure as of yet. It lists that the equipment needed for the testing is a stop watch, engine tachometer, and an Intake manifold absolute pressure (MAP) gauge. To prepare the vehicle for the tests, it must be properly maintained and adjusted for the ambient temperature. This would include at least a quarter tank of fuel, the correct coolant and oil in the engine, correct spark plug type and gapped to the correct value, air cleaner and other common equipment clean and installed. Before the vehicle is soaked before the test, the engine needs to be brought up to a stable operating temperature and driven 10 miles at $45-55 \mathrm{mph}$. If the temperatures are lower than $-18^{\circ} \mathrm{C}$ the distance is increased to 20 miles. After the warm-up and stabilization, the manifold and engine RPM are recorded at idle then the vehicle is put in 
park and shut off. The vehicle is then soaked to the temperature for the desired period of time.

The recommended cold-start procedure is written out starting with obtaining the 'Cold Start and Drivability data sheet' from the SAE document. The engine is started per the manufactures specifications, recording the start time. If the engine fails to start after 15 seconds, cranking is stopped. Follow the manufacturer's recommendations for a no start then try to start the engine again. If the engine does not start after three tries, the vehicle is removed for diagnosing and repair. As soon as the engine starts, the headlights are turned on. The transmission is left in park as the engine is started with manual transmissions being tested with clutch petal compressed and decompressed. The operation is done without forcing the engine to idle which means to keep the throttle closed. The important data to record is the idle speed RPM, manifold air pressure (MAP), and the idle quality described in the document. If the engine stalls, the operator is to return to the starting process. After 15 seconds of idling, the brake is applied and the transmission is shifted into drive (first gear for manuals with clutch engaged) and idled for 10 seconds and record the same information taken earlier. If the engine stalls, a restart is to occur immediately and record the number of stalls. The rest of the document was for the drivability portion which did not apply to this research. All of the rankings and sample data sheet can be found in the SAE document.

This procedure was made for on road vehicles which did not include snowmobiles. Therefore the parts that did not apply to the snowmobiles were interpreted in a way fitted for snowmobiles. The drivability portion of this procedure was not used because of time and budget constraints. This was a good document to base the cold-start procedure for snowmobiles on and was then modified to fit the research needs as far as sampling emissions and other engine parameters.

\subsubsection{Tsunooka 2007, SAE 2007-01-2036}

The goal of this paper was to investigate the effects of high concentrations of ethanol on cold startability. In this research, they used three different fuels of ethanol and 
gasoline mixes including a $95 \%$ ethanol $5 \%$ water (E100) by volume and two $80 \%$ ethanol (E85) by volume fuels. The Reid vapor pressure (RVP) was changed from $52 \mathrm{kPa}$ to $74 \mathrm{kPa}$ between the two $80 \%$ ethanol fuels. The engine that the tests were performed on was a four-cylinder four-stroke engine with a displacement of $1794 \mathrm{cc}$. The engine utilized multi-port injection with a four valve dual overhead camshaft. The engine was controlled to stoichiometry for the air fuel ratio so the injectors and fuel pump were optimized to run the higher fuel flows.

The research validated many ideas from previous work. It was known that the vaporization of ethanol deteriorates with decreasing temperatures. This required more fuel to be injected into the engine to achieve the right air-fuel ratio especially with increased ethanol contents. It was found that the cold startability also deteriorated with the colder temperatures with the limited intake timing. To increase the fuel flow, the fuel pressure was increased but was found to have minimal effect on the amount of fuel needed. Therefore raising the pressure was not sufficient in improving cold startability. The research found that increasing the RVP of the fuel improved the startability significantly.

One of the methods used to improve cold startability was valve timing. The authors initially used an engine model to simulate the airflow into the combustion chamber. During these simulations, all the temperatures were held at a constant $-35^{\circ} \mathrm{C}$. The ideas were then tested on an engine. The results showed that the engine would not start with no valve timing optimization but with the optimization it would start. The results from the testing produced a lower limit of temperature with the same RVP for the fuel.

Another parameter that was tested was the chemical composition of the fuel. The results found that the carbon chains that had less than seven carbons in them vaporized easier. Butane was found to be a great booster of RVP which in turn increased cold startability. They used a device that sampled the gas in the cylinder right before it was ignited to better understand the amount of each fuel that had evaporated. It was found that 
at temperatures colder than $0{ }^{\circ} \mathrm{C}$, the percent concentration of ethanol in the gases decreased significantly.

The major points in this paper that apply to the current research topics are that large amounts of ethanol decrease the startability of an engine without any optimization such as valve timing or changing the fuel constituents or higher RVP. Another point was that as the ambient temperature decreased the amount of ethanol in the evaporated gas cloud decreases significantly. Therefore larger changes should be expected in the data at the colder temperatures. With decreasing temperatures and increasing volume of ethanol, a higher degree of difficulty in starting the engine is expected.

\subsection{Effects of Ethanol}

The following papers are on the effects higher blends of ethanol have on the emissions of the engines.

\subsubsection{Knoll 2009, SAE 2009-01-2723}

From this paper, the researchers sampled emissions using mid-level blends of ethanol; E10 (10\% ethanol-90\% gasoline by volume), E15, and E20. E0 was used as a baseline fuel. They tested these fuels on 16 different cars and trucks with different engines configurations such as different number of cylinders, fuel trim strategies, mileage, and emissions standards. The emissions were sampled using the LA92 drive cycle also known as the Unified Cycle (California 2012). The LA 92 drive cycle was used because it was the most representative of real-world driving. When performing the statistical analysis, percent changes were presented from the E0 baseline fuel averaged across all the vehicles. Standard T-tests were used to determine whether the average change was in the $95 \%$ confidence level.

In Figure 2.1 the change in composite emissions and fuel economy, are presented. When analyzing the data from this paper, the vehicles that did not apply Long Term Fuel Trim (LTFT) were of concern because they represent an engine with an open loop fuel control system. On the plots, the pink and red columns are the data of interest. In the plot, 
not every emission category had a major change. Non-methane organic gases (NMOG) statistically did not have a major change between the different fuels. Non-methane hydrocarbons (NMHC) did have significant changes and for higher blends of ethanol, the hydrocarbons have a negative percent change between 20 and 25\%. CO emissions were also about $25 \%$ lower with the addition of ethanol. NOx increased with higher ethanol. With E20, NOx increased about 35\% which was probably due to the higher temperatures of the combustion with the leaning of the fuel mixture. This experiment also found that fuel economy decreased in both cases with or without LTFT. This was found to be true because of the lower energy content of the fuel with the reduction tracking closely with the measured energy content of the fuel blends. The vehicles that had closed loop control for exhaust oxygen had in most areas no statistical change in emissions. Compensation was performed by changing the amount of additional fuel delivered to the engine to maintain a specified value for lambda. Adding additional fuel does negatively affect the fuel economy as can be seen in the last column of Figure 2.1.

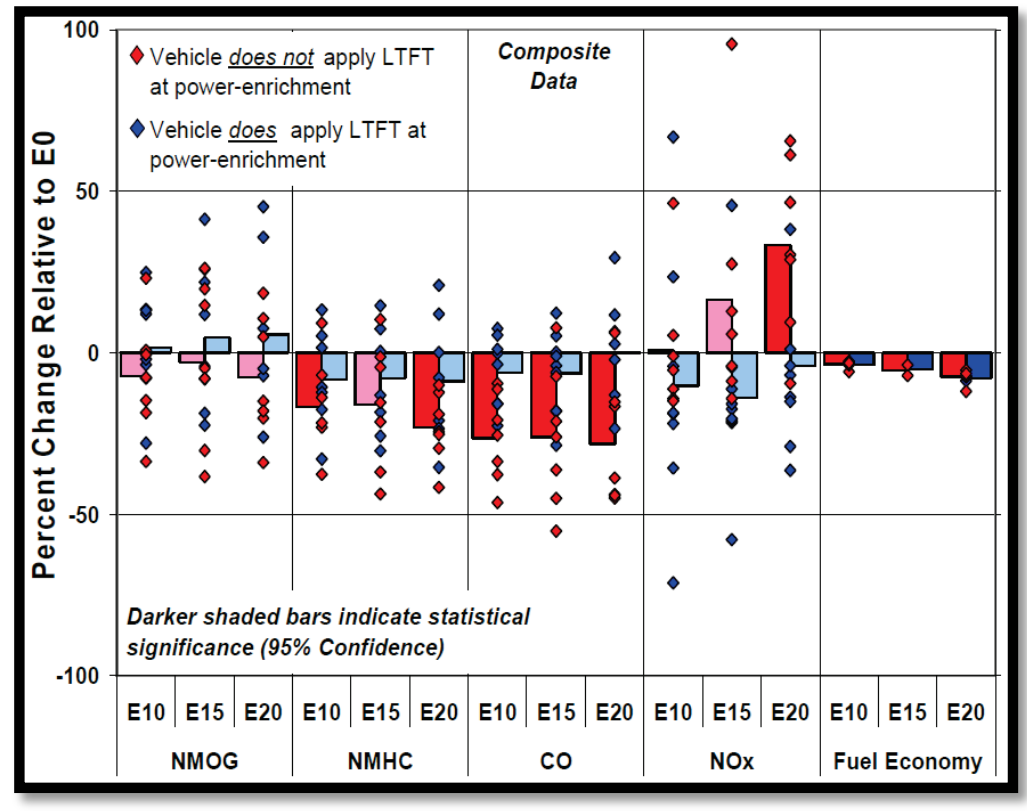

Figure 2.1: Vehicle average percent change in composite emissions and fuel economy relative to $\mathrm{E0}$ (Reprinted from SAE paper 2009-01-2723) 
This research found some of the short term effects of mid-level ethanol blends. Some of the other conclusions that were made from this research were that there was a differentiation between vehicles that utilized LTFT. NMOG and NMHC emissions increased as the power to weight ratio increased with increasing ethanol. The researchers also found that catalyst temperatures increased with vehicles that did not apply LTFT. The higher catalyst temperatures could have a negative effect on the expected life of the materials inside the catalyst but a full-useful-life durability study would have to be performed to confirm this conclusion.

\subsubsection{Bresenham 1999, SAE 1999-01-3345}

This study focused on comparing emissions of hydrocarbons (HC), carbon monoxide $(\mathrm{CO})$, and oxides of nitrogen $(\mathrm{NOx})$ of small engines operated on a range of ethanol blended gasoline. This was done with three different small engines which two were side valve 12.5hp Briggs and Stratton engines and one 12.5hp Kohler overhead valve engine. The engines were four-stroke air-cooled configurations. The factory air to fuel ratios were used to show the effects of ethanol on engines that were being used already which are not optimized to run on oxygenated fuels. They used E0, E10, E25 and E50 (all \% volume). The equivalence ratio was used to normalize the effect of the different stoichiometric air-fuel ratios. The equivalence ratio was determined after testing was completed by using the Spindt Method and Spindt Method Modification for the ethanol mixes (Bresenham 1998). The engines were tested on a small engine eddy current dynamometer and the SAE J1088 standard test was used which is a subset of the EPA small engine test procedure. During the test, five stages at $85 \%$ of rated speed with varying loads and one additional, no load idle stage were performed. The exhaust emissions were collected and measured by a 5 gas Pierburg analyzer and fuel flow was measured by using an AVL gravimetric fuel flow meter.

The emissions results are displayed in Table 2.1. The table shows the HC, NOx, and $\mathrm{CO}$ emissions compared to each of the fuels in all three engines. The $\mathrm{HC}$ emissions trended downwards as the ethanol content was increased. The NOx emissions showed the 
opposite trend when compared to $\mathrm{HC}$. The concentration of NOx increased as the ethanol content increased. This was because the combustion temperature increased as the fuel/air mixture moved towards stoichiometry. When looking at both $\mathrm{HC}$ and NOx emissions, there was a trade-off: the higher the ethanol content, the lower the $\mathrm{HC}$ emissions but there were higher NOx emissions also. When looking at the $\mathrm{CO}$ emissions, they decreased with increasing ethanol content like $\mathrm{HC}$ did. The addition of an oxygenated fuel was very effective towards reducing the $\mathrm{CO}$ emissions in these engines.

The conclusions made from this experiment were that increasing the content of ethanol in the fuel decreased $\mathrm{HC}$ and $\mathrm{CO}$ emissions but due to the higher combustion temperatures, NOx emissions increased. These measurements were made with no compensation for different values of lambda. While using equivalence ratio normalization, it was also found that NOx emissions were insensitive to valve positioning but hydrocarbons and carbon monoxide were lower.

Table 2.1:

Summary of emissions results with small engines

\begin{tabular}{|c|c|c|c|c|c|c|c|c|c|}
\hline Engines & \multicolumn{2}{|c|}{ Engine \#5 Side Valve } & \multicolumn{3}{|c|}{ Engine \#6 Side Valve } & \multicolumn{3}{|c|}{$\begin{array}{c}\text { Engine \#7 Overhead } \\
\text { Valve }\end{array}$} \\
\hline Fuels & $\begin{array}{c}10 \% \\
\mathrm{EtOH}\end{array}$ & $\begin{array}{c}25 \% \\
\mathrm{EtOH}\end{array}$ & $\begin{array}{c}50 \% \\
\mathrm{EtOH}\end{array}$ & $\begin{array}{c}10 \% \\
\mathrm{EtOH}\end{array}$ & $\begin{array}{c}25 \% \\
\mathrm{EtOH}\end{array}$ & $\begin{array}{c}50 \% \\
\mathrm{EtOH}\end{array}$ & $\begin{array}{c}10 \% \\
\mathrm{EtOH}\end{array}$ & $\begin{array}{c}25 \% \\
\mathrm{EtOH}\end{array}$ & $\begin{array}{c}50 \% \\
\mathrm{EtOH}\end{array}$ \\
\hline $\begin{array}{c}\text { \% } \\
\text { Change } \\
\text { HC }\end{array}$ & $-8 \%$ & $-22 \%$ & $-72 \%$ & $-11 \%$ & $-37 \%$ & $\begin{array}{c}\text { No } \\
\text { Data }\end{array}$ & $4 \%$ & $-18 \%$ & $-40 \%$ \\
\hline $\begin{array}{c}\text { \% } \\
\text { Change } \\
\text { NOx }\end{array}$ & $12 \%$ & $44 \%$ & $85 \%$ & $36 \%$ & $152 \%$ & $\begin{array}{c}\text { No } \\
\text { Data }\end{array}$ & $-10 \%$ & $84 \%$ & $211 \%$ \\
$\begin{array}{c}\text { \% } \\
\text { Change } \\
\text { CO }\end{array}$ & $-19 \%$ & $-50 \%$ & $-92 \%$ & $-21 \%$ & $-62 \%$ & $\begin{array}{c}\text { No } \\
\text { Data }\end{array}$ & $-2 \%$ & $-43 \%$ & $-74 \%$ \\
\hline
\end{tabular}

\subsection{Snowmobile Emissions}

This section focuses on literature written about snowmobile emissions. 


\subsubsection{Wright 1998, SAE 982017}

This paper described the efforts taken to develop and validate a snowmobile engine emission test procedure. When this paper was written in 1998, there was no procedure for testing snowmobile engines for emissions so the snowmobiles were tested using the small engines test procedure CARB J1088 Test Cycle. The reason for producing a procedure specifically for snowmobiles was because the J1088 small engines procedure was not a very good representation of normal snowmobile operation. The researchers proved this by taking real time data on snowmobiles from each of the four manufactures (Arctic Cat, Polaris, Ski-doo, and Yamaha). The snowmobiles were tested in the Upper Peninsula of Michigan using five different typical riding styles. The five styles were aggressive (trail), double (trail with a passenger), freestyle (off-trail), lake driving and moderate (trail). The researchers recorded speed power and torque to propose a test cycle with 5 modes with different weighting factors. Table 2.2 shows a comparison of the two different test cycles. The proposed modes and weighting factors were all produced from the data taken in the field.

Table 2.2:

Comparison of $\mathbf{J 1 0 8 8}$ test cycle and proposed snowmobile test cycle

\begin{tabular}{|c|c|c|c|c|c|c|}
\hline J1088 Mode & $\mathbf{1}$ & $\mathbf{2}$ & $\mathbf{3}$ & $\mathbf{4}$ & $\mathbf{5}$ & $\mathbf{6}$ \\
\hline \% of rated speed & 85 & 85 & 85 & 85 & 85 & Idle \\
\hline \% of max. load & 100 & 75 & 50 & 25 & 10 & 0 \\
\hline Weight factor (\%) & 9 & 20 & 29 & 30 & 7 & 5 \\
\hline Proposed Modes & $\mathbf{1}$ & $\mathbf{2}$ & $\mathbf{3}$ & $\mathbf{4}$ & $\mathbf{5}$ & - \\
\hline \% of rated speed & 100 & 85 & 75 & 65 & Idle & - \\
\hline \% of max torque & 100 & 51 & 33 & 19 & 0 & - \\
\hline Weight factor (\%) & 12 & 27 & 25 & 31 & 5 & - \\
\hline
\end{tabular}


Emissions were sampled using a modified EPA marine engine test procedure,. When sampling emissions, there are many factors that affect the emissions such as intake air conditions and sample probe location. For this reason the correct jetting for the ambient temperature and pressure, inlet air of 10 to $20^{\circ} \mathrm{C}$, and fan blowing over the engine were recommended. The use of a water brake dynamometer was not recommended because of the oscillation or erratic behavior the two-stroke engines can produce.

To sample the emissions, the EPA marine procedure specifies that a heated FID and heated primary sample line should be used. This is because two-stroke engines emit hydrocarbons that could condense on the walls of an unheated sample line. To be able to compare many different types of snowmobiles the results are to be produced in grams $/ \mathrm{kW}$-hr. To normalize the emissions, either the intake air mass flow or fuel flow needs to be measured. While instrumenting the intake for this measurement could affect the operation of the snowmobile, it is recommended to measure the fuel flow. The suggested procedure was tested in a round-robin emissions test by sending two engines around to all of the participating manufactures to determine the repeatability of the test procedure. The researchers found that there was quite a bit of variation in the emissions between each location and suggested that the variation could be from dynamometer performance, sample probe location, carburetor adjustment and intake air conditions. The researchers summarized that there would be a certain level of variation between the testing locations because the combustion of high-performance two-strokes can be unstable at partial throttle points.

This paper relates to this research as far as the specifications for the emissions sample probe and the setup of the test. It also concluded that there will always be some variability in the tests because of the engine operation at different locations. It also gave a better understanding of how emissions were taken on snowmobiles. 


\subsection{Literature Review Summary}

After searching for and reviewing many papers with anything related to snowmobile cold-start testing, it was found that there is little documented data on this subject. The papers that were reviewed provided some insight on how cold-start testing was performed and the effect of ethanol added to gasoline has on cold start. When performing cold-starts on motor vehicles, it is important to be consistent and to record all data that is necessary to be able to explain the trends. When using ethanol added to fuel, it leans out the stoichiometric air to fuel ratio, if no modifications are made to the engine for the different fuel. Ethanol has a higher heat of vaporization that causes a smaller amount of fuel to evaporate which causes concern when trying to start an engine at reduced temperatures.

The emissions of engines do change when ethanol is added to gasoline. Some of the trends found are that as the engines are operated leaner, less $\mathrm{HC}$ and $\mathrm{CO}$ and more $\mathrm{CO}_{2}$ were observed for engines operating on open loop control strategies. The other trend observed was that as the engine leans out, the temperatures rise and therefore more $\mathrm{NO}_{\mathrm{x}}$ is produced. Overall, there has not been that much research that has been done on snowmobile emissions and hopefully this thesis can help answer some of the questions that arise when engines run oxygenated fuels with no compensation at sub-ambient temperatures.

\section{Chapter 3 Experimental Setup}

The goal of this research was to investigate the effects of E15 on the cold startability of snowmobiles at different temperatures. There were four test vehicles used that represented the wide range of engine and fuel delivery configurations in the snowmobile industry. A baseline test using E0 (pure gasoline) was performed, then the fuel was changed to E15 (15\% ethanol, $85 \%$ gasoline by volume) and the same test was performed. Octane number for the fuels was matched to what each manufacture recommended for each snowmobile. Therefore, an octane rating of $87 \mathrm{R}+\mathrm{M} / 2$ was used 
for the Yamaha and Arctic Cat, and $91 \mathrm{R}+\mathrm{M} / 2$ was used for the Ski-doo and Polaris. The cold-start tests were performed at three different temperatures: $20^{\circ} \mathrm{F}, 0{ }^{\circ} \mathrm{F}$, and $-20^{\circ} \mathrm{F}$. When the temperatures for the cold-start tests were originally proposed, the English system of Fahrenheit $\left({ }^{\circ} \mathrm{F}\right)$ was used. However in this report, all of the results and explanations are given in the Metric units of Celsius $\left({ }^{\circ} \mathrm{C}\right)$. The tests will be labeled as 20 ${ }^{\circ} \mathrm{F}, 0{ }^{\circ} \mathrm{F}$, and $-20^{\circ} \mathrm{F}$ for simplicity reasons.

To ensure repeatability, at least three different tests at each temperature were completed. Each test vehicle was equipped with a DAQ system which recorded various temperatures, accelerations, frequencies (speeds), and running time. Emissions taken during the cold-start process were sampled using a Sensors Inc. Semtech-DS five-gas raw emissions analyzer. This unit was capable of measuring $\mathrm{CO}_{2}, \mathrm{CO}$, THC, $\mathrm{NO}$ and $\mathrm{O}_{2}$. Since NO is not a regulated constituent from snowmobiles, the measured results are not presented in this thesis. The data was post-processed in Matlab to generate plots and visually checking for consistent trends.

\subsection{Test Cell}

In order to test at the different temperatures, a test cell with controllable temperature was needed. A control room that supported computers and test equipment above freezing was required. An external room that contained the emissions analyzer and support gases for the analyzer was utilized. The most cost effective solution that could handle all of the requirements listed above was a 48 foot refrigerated cold start trailer.

\subsubsection{Cold-Start Trailer Layout}

Modifications were made to the refrigerated cold start trailer to suit the requirements of the testing. The layout of the trailer can be observed in Figure 3.1. This trailer was originally designed by Abhishek Manekar who was a previous MS student of Michigan Technological University. He designed this trailer to do similar cold-start testing on a Saturn Vue (Manekar 2010). As seen in Figure 3.1 and Figure 3.2, the cold start trailer was divided into two different parts; the temperature controlled cell and the 
control room. The temperature controlled area was originally designed to be able to hold a vehicle that was 15 feet long and 7.5 feet wide. This area did not have to be modified to accommodate four snowmobiles, but they had to be orientated in a certain way to be able to sample the emissions and remove the exhaust effectively. There was no need to modify the control room either, as it was already set up to accommodate the test computer and other storage needs.

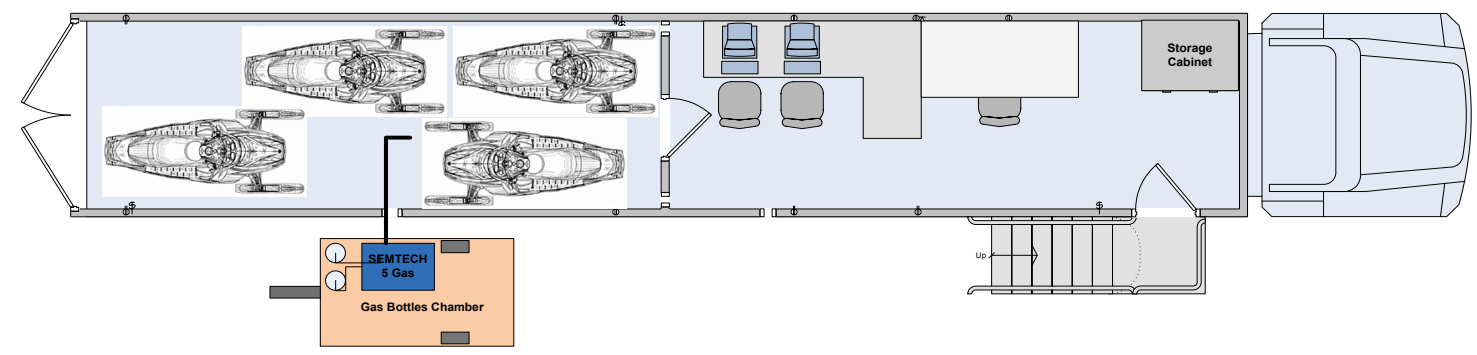

Figure 3.1: Cold-start test cell trailer layout

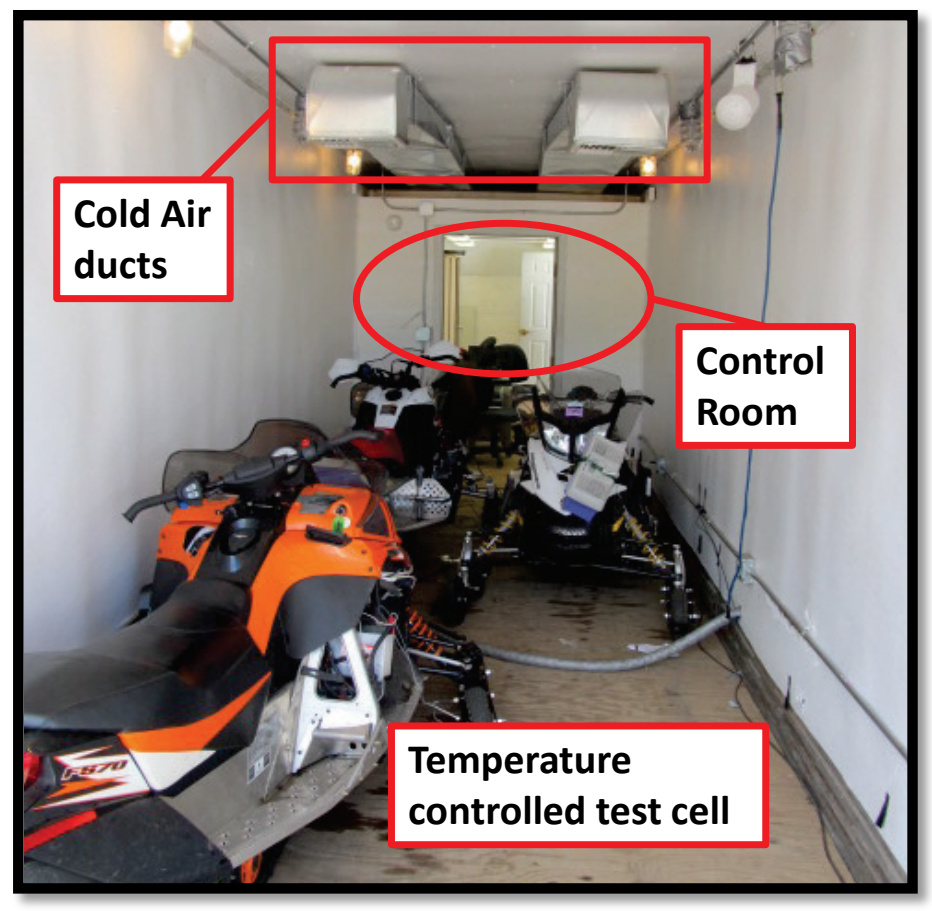

Figure 3.2: View from the back of test cell looking forward into the control room 
Before each test, the engines were brought up to operating temperature and driven a predetermined distance to get rid of any excess fuel leftover in the engine. A ramp was built out of aluminum car ramps secured to the trailer with plywood placed on top and an old snowmobile track screwed down to the plywood for traction. This allowed for easy access in and out of the trailer to clean the engines out between tests. The ramp used is pictured in Figure 3.3.

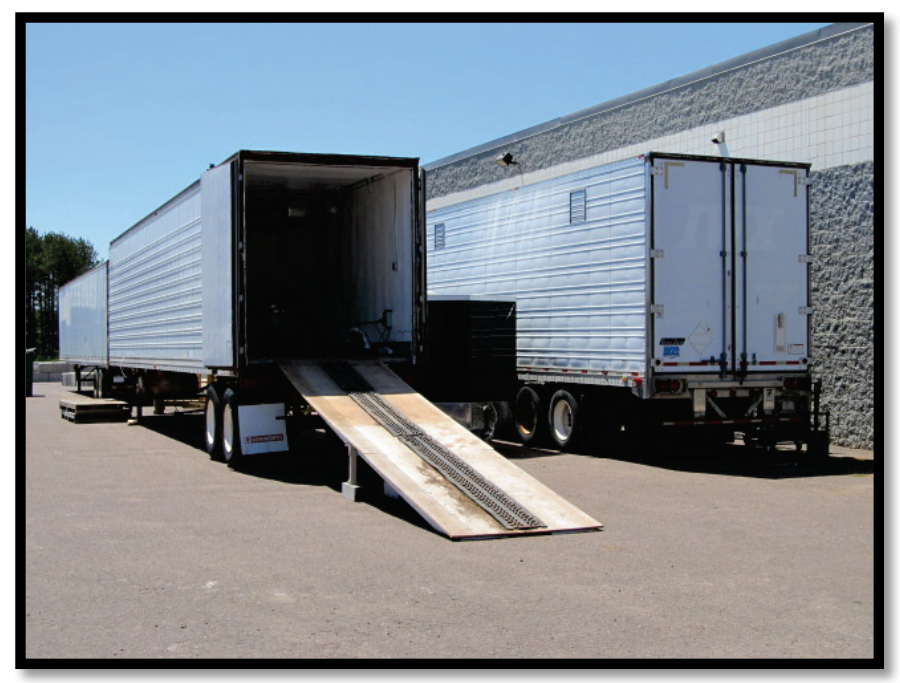

Figure 3.3: Snowmobile ramp built for easy access in and out of test cell

\subsubsection{Cooling Ductwork}

When the temperature controlled trailer was modified, a system of ductwork was designed to get the cool air coming out of the refrigerator on the front of the trailer back to the cold room. The two ducts were 5 inches by 20 inches to provide enough volume to deliver the cold air efficiently. The ductwork can be seen in Figure 3.4 where the two ducts supply the cold air to the test cell and the spaces around the ducts in between the ceiling of the control room and the roof of the trailer is the return air to the refrigerator. These outlets deliver the cold air around all of the four snowmobiles located in the cold test cell. The control room was sealed off from the cold test cell and heated by a small space heater to prevent the operating equipment from freezing. 


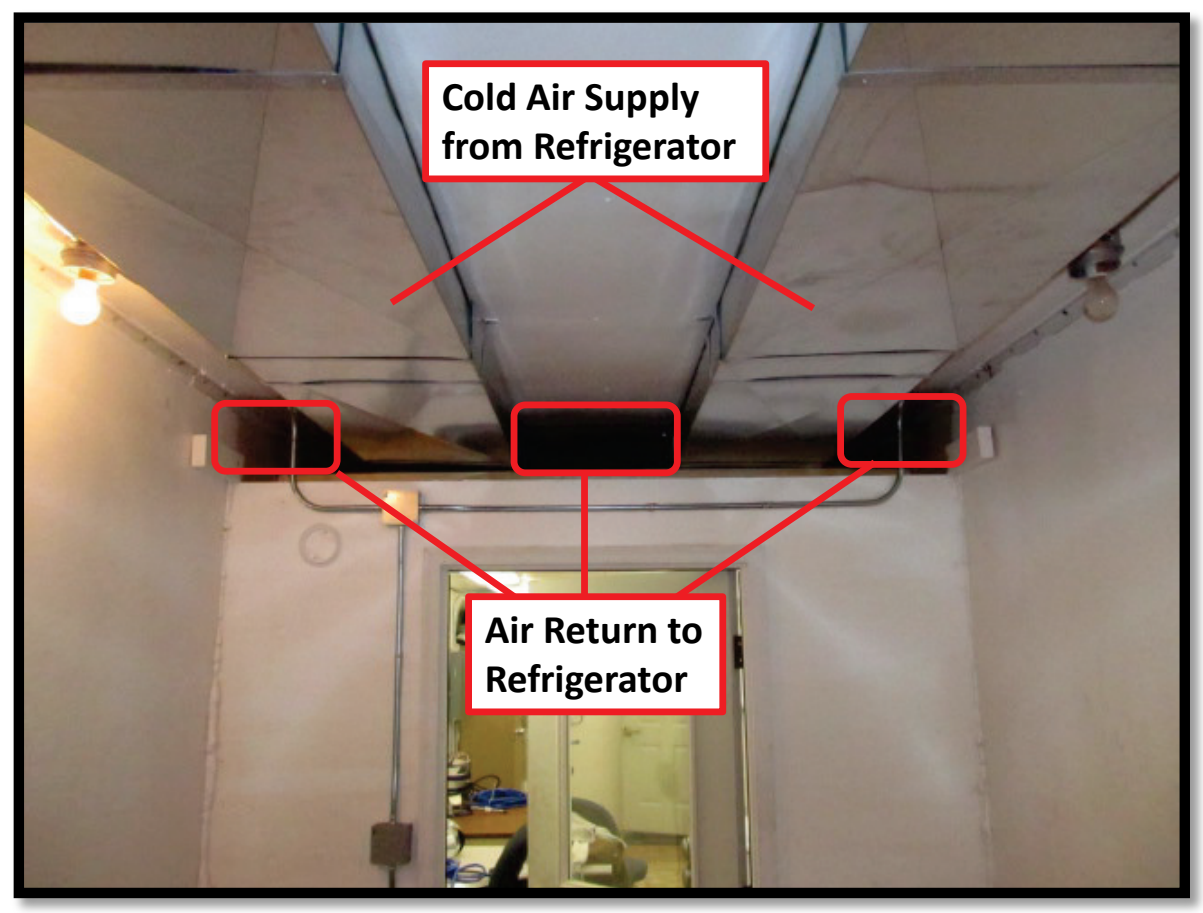

Figure 3.4: Cold air ductwork for test cell

\subsubsection{Exhaust System}

The test cell was sealed off from the outside to be able to cool the room down to the desired temperature. This meant that the test snowmobiles would be using the room air for the intake air into the engine. Therefore, the exhaust from the snowmobiles had to be evacuated from the cold test cell without taking all of the cold air out of the room. A flexible hose was used to be able to attach to the four different exhaust outlets in the test cell. A fixed exhaust for all four snowmobiles would not have been plausible because of the fact that the snowmobiles needed to be removed from the test cell each time to be cleaned out. The flexible hose can be seen in Figure 3.5 attached to the exhaust of the Ski-doo MX Z TNT. 


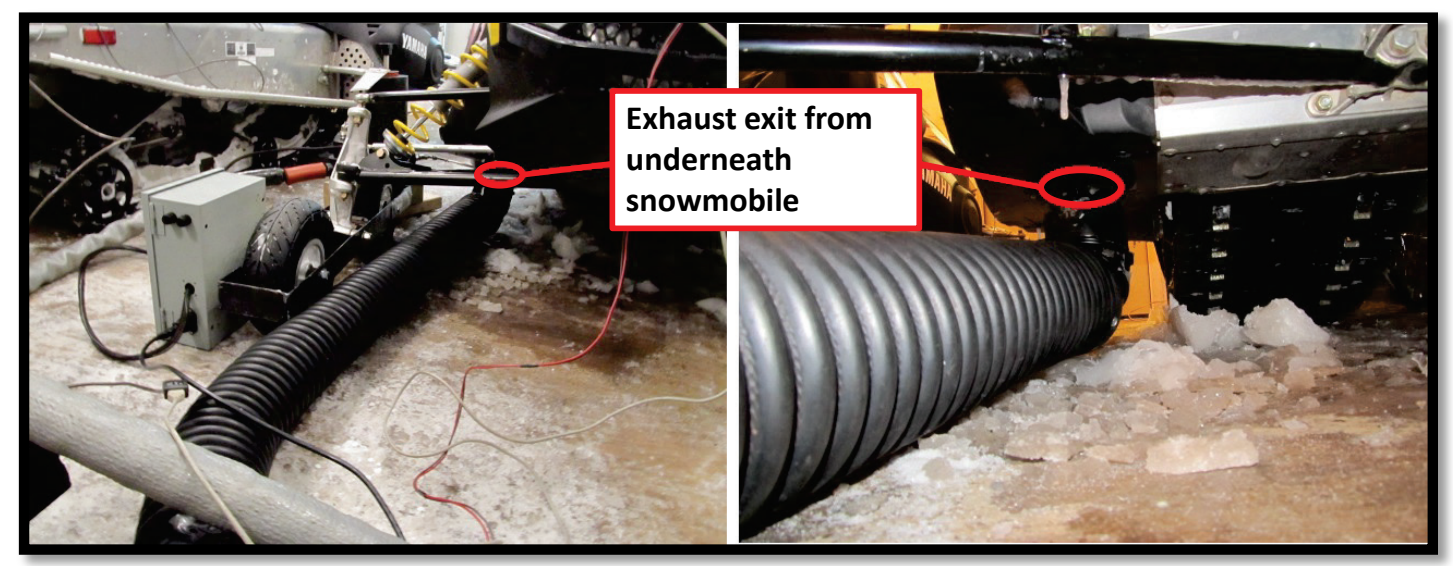

Figure 3.5: Example of how the engine exhaust was removed from the test cell

There was not a complete seal on each of the snowmobile's exhaust so a DC inline duct fan was implemented to pull the exhaust out of the room. The fan was capable of moving 235 CFM which was more than the flow of exhaust that any of the snowmobiles output during idle. Figure 3.6 shows the exhaust fan attached to the rear door of the test trailer. With the fan fixed to the door and being able to remove the flexible exhaust hose from the fan, it was easier to move the snowmobiles in and out of the trailer. The coupler on the exhaust hose was also notched on one side so an emissions sampling probe could be placed in the exhaust.

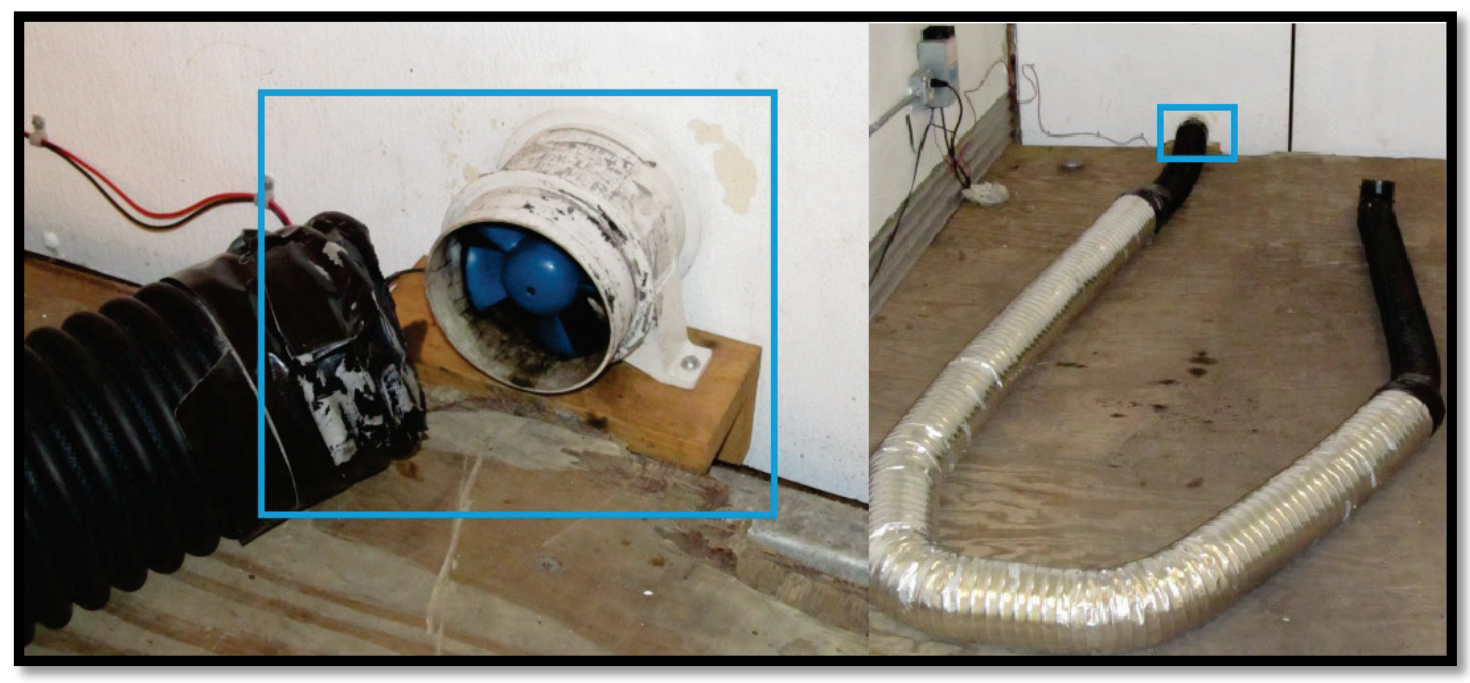

Figure 3.6: Exhaust duct fan and exhaust hose mounted in rear door of trailer 


\subsubsection{Emissions Sampling Setup}

To sample emissions from the engines during the cold start tests, an emissions probe for each of the test vehicles was installed. These emissions probes were made out of $1 / 4$ inch stainless steel tubing. They were bent in ways to allow the probe to be pushed as far into the mufflers as they would go. Approximately 12 inches of sample probe were inserted into the mufflers. Figure 3.7 is an example of the Ski-doo emissions probe. The probes were inserted as far as they would go to try to prevent the emissions bench from pulling air into the analyzer from the room. If the emissions analyzer was pulling in clean room air, that would dilute the emissions from the snowmobiles and output a false reading. These exhaust probes were secured to the snowmobile so the probe would not have to be removed after every test. It was convenient to switch from one snowmobile to the next because the same Swagelok compression fittings were attached to each probe.

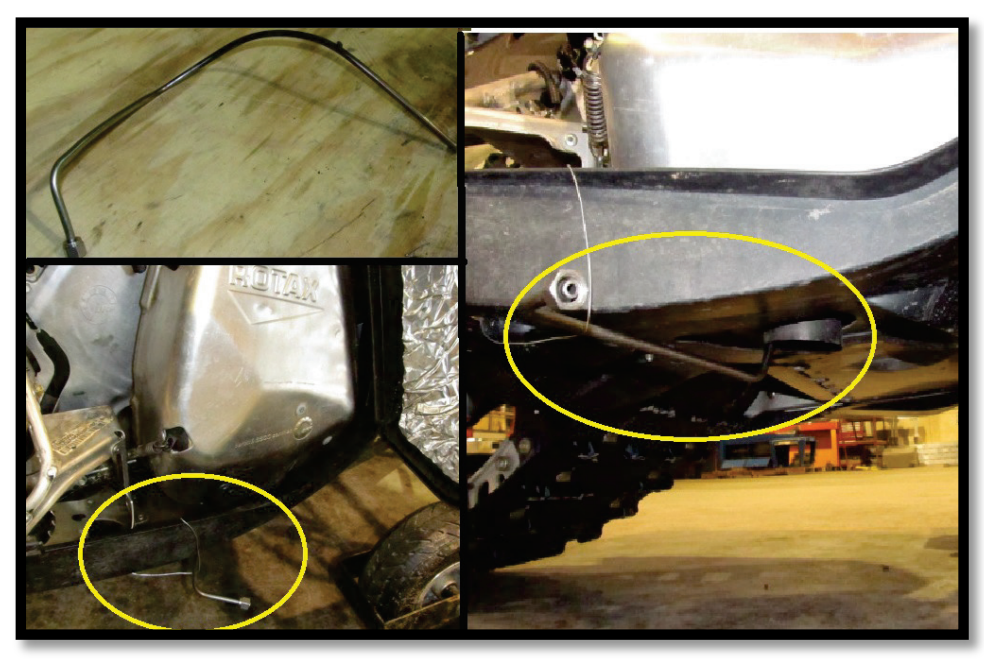

Figure 3.7: Example of the emissions sampling probe located in the exhaust

The Semtech DS emissions analyzer was attached to each of the snowmobiles by a flexible heated sampling line. This line is pictured in Figure 3.8. The Semtech was originally going to be in the test cell so the sampling line could be attached to each of the snowmobiles but the emissions analyzer required an ambient temperature higher than $32^{\circ} \mathrm{F}$. A possible solution was to locate the analyzer inside the control room where it would be held at a temperature above freezing but then the sample line would not reach 
all of the snowmobiles. The final solution was to place the emissions analyzer and supporting gas bottles in a small utility trailer that was located right next to the test cell as in Figure 3.1. A hole was cut in each wall of the test cell and the utility trailer to permit the access of the sample line into the test cell.

During the first few cold start tests, the sample line was connected directly to the sample probes. It was found that the small heated filter on the front of the emissions analyzer was clogged quickly due to high hydrocarbon concentration of the two-stroke engines and required frequent changes. This would have been very expensive to use as a long term solution so a large heated filter was placed between the sample probe and the heated sampling line. When this heated filter in Figure 3.9 was added, the emissions did not change. This heated filter was set to a temperature of $191{ }^{\circ} \mathrm{C}$ which was the same temperature as the heated sample line. Due to the larger filter surface area, the filter did not need to be changed as frequently as the small filter.

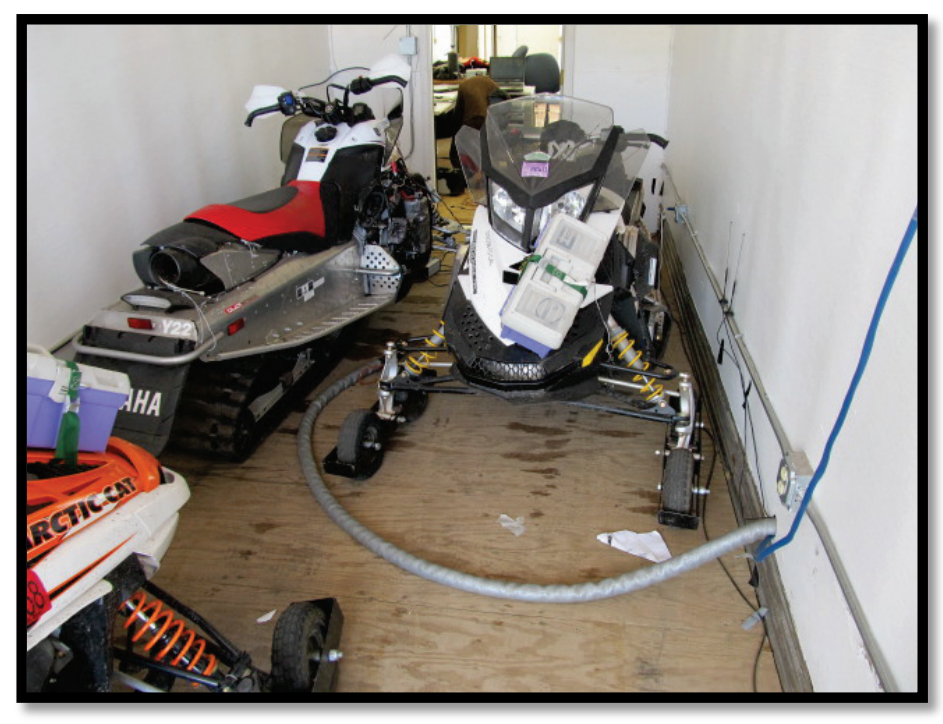

Figure 3.8: Semtech heated emissions sample line in test cell 


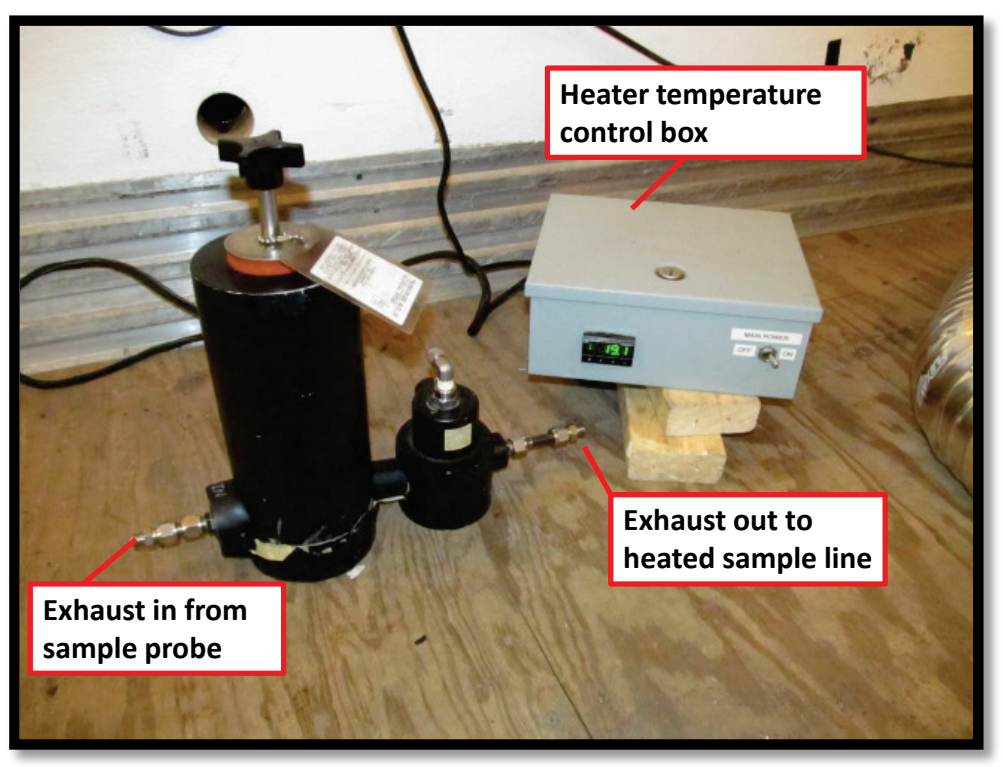

Figure 3.9: External heated filter with temperature control box

\subsection{Test Vehicle Descriptions}

The vehicles selected ranged from four-stroke to two stroke and electronic direct injection to carburation which represented the wide range of configurations in the snowmobile industry. All of the vehicles were controlled on open-loop control strategies. This means that the snowmobiles did not have any way to compensate for the differences in fuels. In a closed loop control system, engines have a lambda or $\mathrm{O}_{2}$ sensor which gives feedback to the ECU to target a certain lambda value. The following sections describe each of the four snowmobiles that were used in the cold-start tests. The engine parameters for all snowmobiles are displayed in Table 3.1. All of the test vehicle engines were broke in and were also used for previous research tests such as drivability and on snow emissions analysis. 
Table 3.1:

Snowmobile Test Vehicle Information

\begin{tabular}{|c|c|c|c|c|}
\hline Specifications & $\begin{array}{c}\text { 2011 Ski-doo } \\
\text { MX Z TNT } \\
\text { FX Nytro RTX } \\
\text { Eng HO E- } \\
\text { TEC }\end{array}$ & $\begin{array}{c}\text { 2011 Polaris } \\
\mathbf{8 0 0} \text { Rush }\end{array}$ & $\begin{array}{c}\text { 2008 Arctic } \\
\text { Cat F-570 }\end{array}$ \\
\hline $\begin{array}{c}\text { Yamaha Genesis } \\
\text { 1049cc four- } \\
\text { stroke, triple with } \\
\text { Idle Speed } \\
\text { Control Motor }\end{array}$ & $\begin{array}{c}\text { Rotax E-TEC } \\
594.4 \mathrm{cc} \text { two- } \\
\text { stroke, twin } \\
\text { cylinder }\end{array}$ & $\begin{array}{c}\text { Liberty 795cc } \\
\text { two-stroke, } \\
\text { twin cylinder }\end{array}$ & $\begin{array}{c}\text { Suzuki/Arctic } \\
\text { Cat 565cc } \\
\text { two stroke, } \\
\text { twin cylinder }\end{array}$ \\
\hline Puel system & $\begin{array}{c}\text { Mikuni 41mm } \\
\text { fuel injection } \\
\text { (PFI) }\end{array}$ & $\begin{array}{c}\sim 130 \mathrm{hp} \\
\text { Direct Injection } \\
\text { (DI) }\end{array}$ & $\begin{array}{c}\text { Fuel Injection } \\
\text { (SDI) }\end{array}$ & $\begin{array}{c}\text { Clectronic } \\
\text { Carburetors } \\
\text { Dual }\end{array}$ \\
\hline $\begin{array}{c}\text { Cooling } \\
\text { system }\end{array}$ & Liquid & Liquid & Liquid & Fan \\
\hline Fuel type & $87 \mathrm{R}+\mathrm{M} / 2$ & $91 \mathrm{R}+\mathrm{M} / 2$ & $91 \mathrm{R}+\mathrm{M} / 2$ & $87 \mathrm{R}+\mathrm{M} / 2$ \\
\hline
\end{tabular}

\subsubsection{Yamaha FX Nytro RTX}

Pictured in Figure 3.10 is the Yamaha FX Nytro RTX. Some of the important features of this snowmobile are a 1049cc three cylinder, four stroke engine with port fuel injection (PFI). The Yamaha Genesis Engine required 87 octane fuel and used semi synthetic Yamalube 4-S 0W-30 engine oil. This specific engine was liquid cooled and was rated at $130 \mathrm{HP}$. The engine had an Idle Speed Control (ISC) unit which operates the butterfly plates in the throttle bodies to increase the idle speed when the engine coolant is cold. This is an effective feature that allows the operator to just turn the key and the engine calibration will go through its warm-up stage without having to operate a choke lever or adjust a high-idle lever. The ISC unit proved to be very consistent throughout the cold-start tests. 


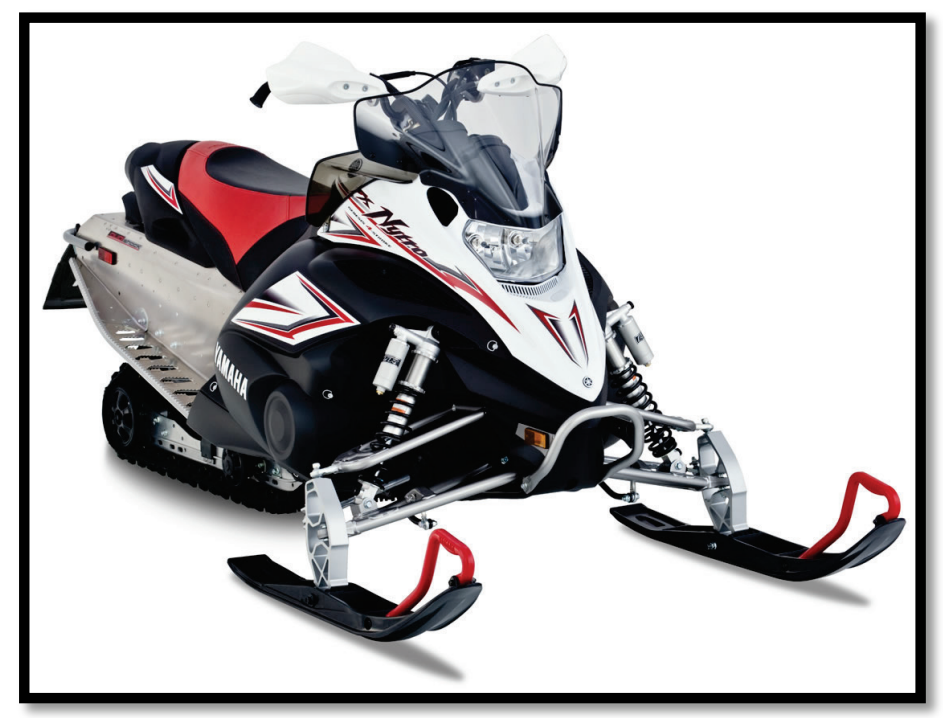

Figure 3.10: Yamaha FX Nytro RTX test snowmobile

\subsubsection{Ski-doo MXZ TNT 600 H.O. E-TEC}

To represent a fuel efficient trail snowmobile, the Ski-doo MX Z TNT 600H.O. E-TEC was used. Some of the important features of this snowmobile are that it had a 594.4cc two-stroke engine with Electronic Direct Injection (DI). The Rotax E-TEC twin cylinder engine required 91 octane fuel and used XPS 2-stroke synthetic blend oil. This engine was liquid cooled and was rated at $120 \mathrm{HP}$. A unique feature about this engine is that it operates lean of stoichiometry which is about 14.6 for gasoline. Therefore the wideband sensor that was installed was maxed out at 16.00 for an air to fuel ratio. It also has exhaust valves with multi stage operation to broaden the power-band. The fuel delivery on this engine is electronically controlled and directly injected into the cylinder at a precise time. This is part of the reason that it can be operated at AFR lean of stoichiometry. This snowmobile also does not inject any oil when it is idling which leads to slightly cleaner emissions. 


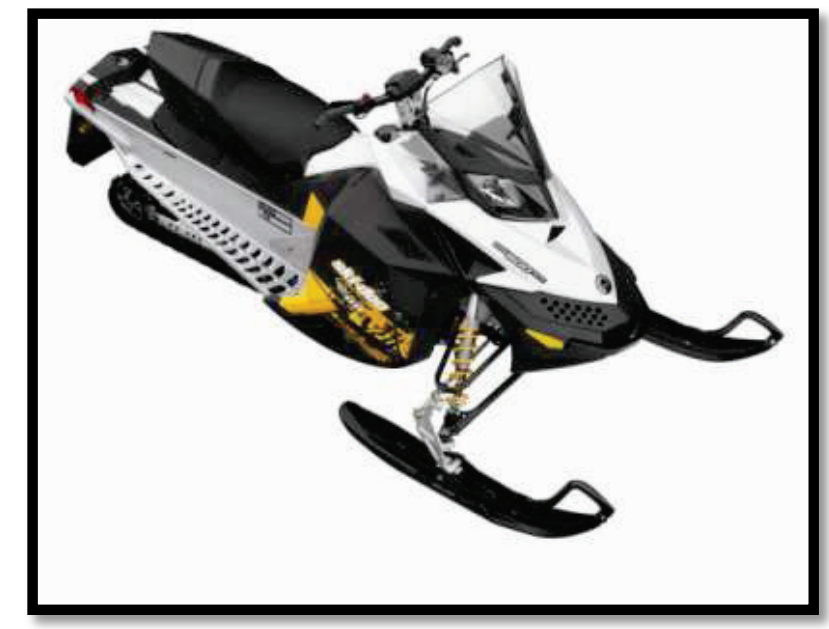

Figure 3.11: Ski-doo MX Z TNT 600 H.O. E-TEC test snowmobile

\subsubsection{Polaris 800 Rush}

To represent a high horsepower and trail friendly snowmobile, the Polaris 800 Rush pictured in Figure 3.12 was used. Important features on this snowmobile include the 795 cc 140 HP twin cylinder two stroke engine with Polaris' Cleanfire Electronic Fuel Injection (EFI). The Cleanfire EFI is a semi-direct fuel injection (SDI) system in which electronic fuel injectors deliver fuel into the crankcase of the snowmobile. The engine required 91 octane fuel and was liquid cooled. This snowmobile also had exhaust valves that open and close to achieve optimal power and torque across a wider range of RPM. A resistor was replaced in the wiring harness when operated with ethanol fuel to allow the ECU to compensate for the fuel. With no choke on this machine the ECU controlled the fuel delivery during warm-up and proved to be very consistent throughout the cold-start tests. 


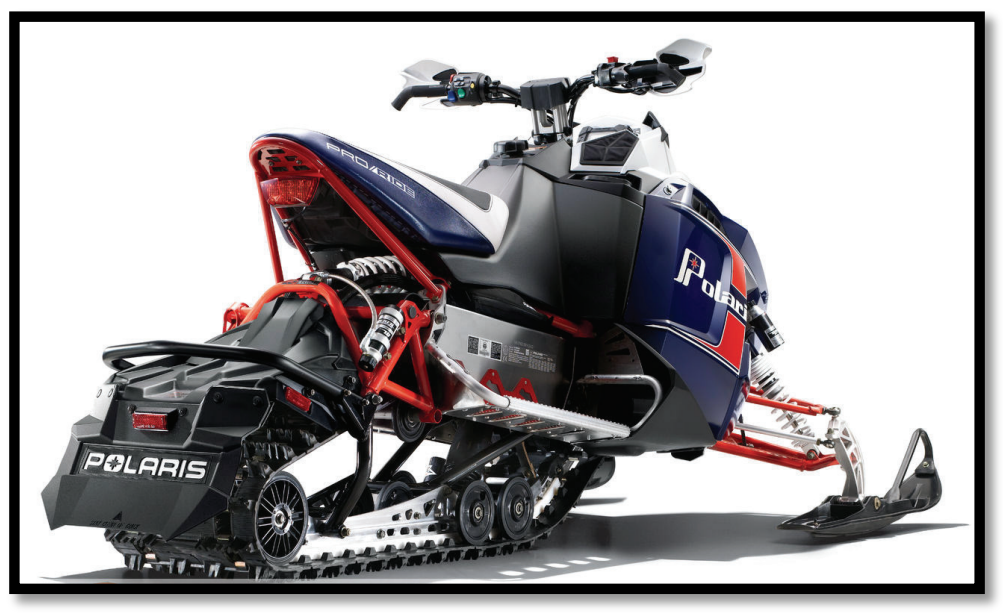

Figure 3.12: Polaris 800 Rush test snowmobile

\subsubsection{Arctic Cat F570}

To represent some of the legacy snowmobiles still traveling the trails today, an Arctic Cat F570 snowmobile was used. This represented some of the older technologies in the snowmobile industry because this snowmobile was carbureted and fan cooled. The Suzuki/Arctic Cat 565cc two-stroke twin cylinder engine was rated at $65 \mathrm{HP}$. It had dual VM 34mm round-slide carburetors and required 87 octane fuel. This snowmobile did not have any way to adjust for the E15 fuel. This snowmobile had a choke to enrichen the airfuel charge to improve the cold startability. This proved to be the most difficult out of the four snowmobiles to be consistent with because of all the variables that go into its cold startup procedure as far as number of pulls and timing of turning the choke off.

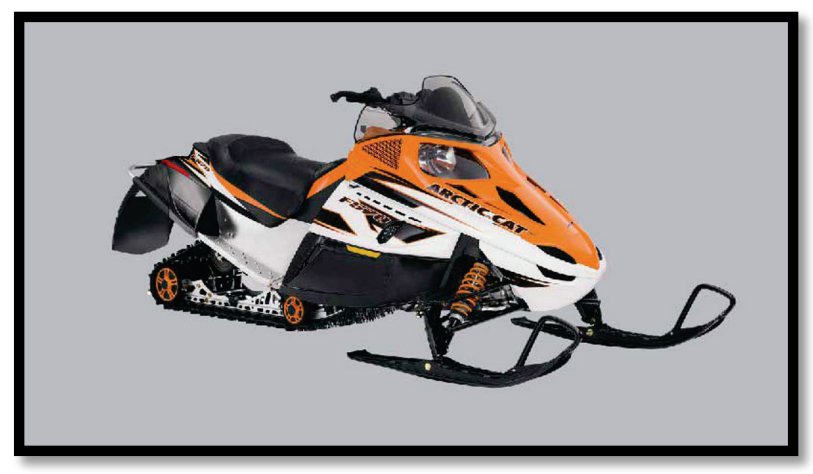

Figure 3.13: Arctic Cat F570 test snowmobile 


\subsubsection{Wheel Skis}

In order to complete the cold-start testing when snow was not available, modifications were made to the snowmobile's skis. The skis were removed and custom wheeled skis were manufactured. These wheel skis were made from small 10 inch "Pocket Rocket" rubber tires that were mounted to the snowmobile using steel frames. The modified ski can be seen in Figure 3.14. The wheels were attached to the steel frame by long bolts and the frame was also attached to the spindle of the snowmobiles by long bolts.

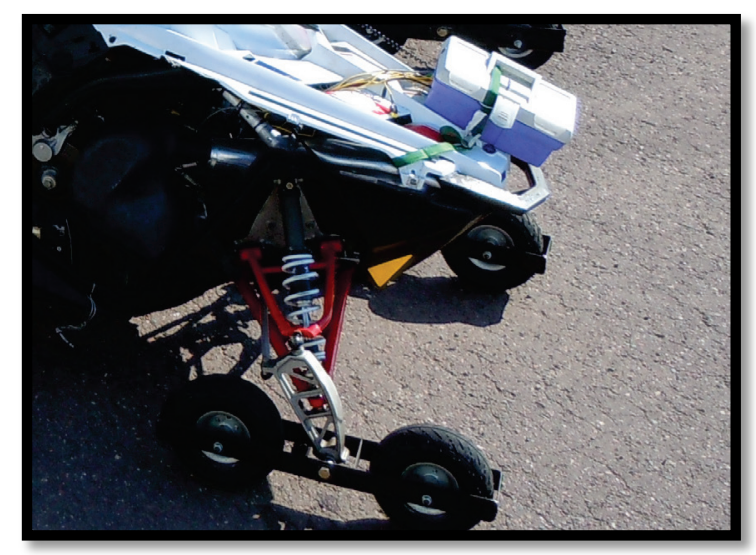

Figure 3.14: Custom wheel skis installed

\subsection{Vehicle Instrumentation}

When instrumenting a test vehicle, it is important to not affect the normal operation of the engine being tested. Therefore the modifications made were to only observe the changes between the two fuels, E0 and E15. The following tables and figures show the different measurements that were taken on each snowmobile. The data acquisition box was made out of a small utility box and secured to the hood of each snowmobile. An example of the data acquisition box is shown in Figure 3.15 and Figure 3.16 . 

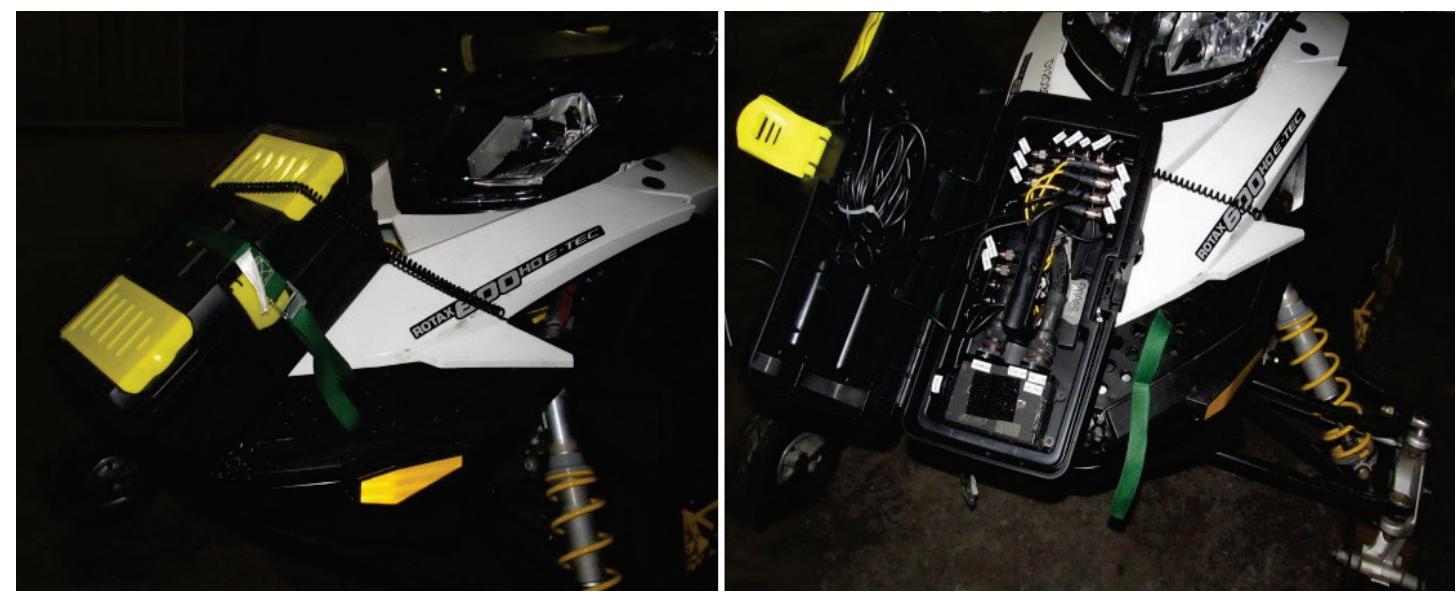

Figure 3.15: Data acquisition box placed on top of the hood of the Ski-doo

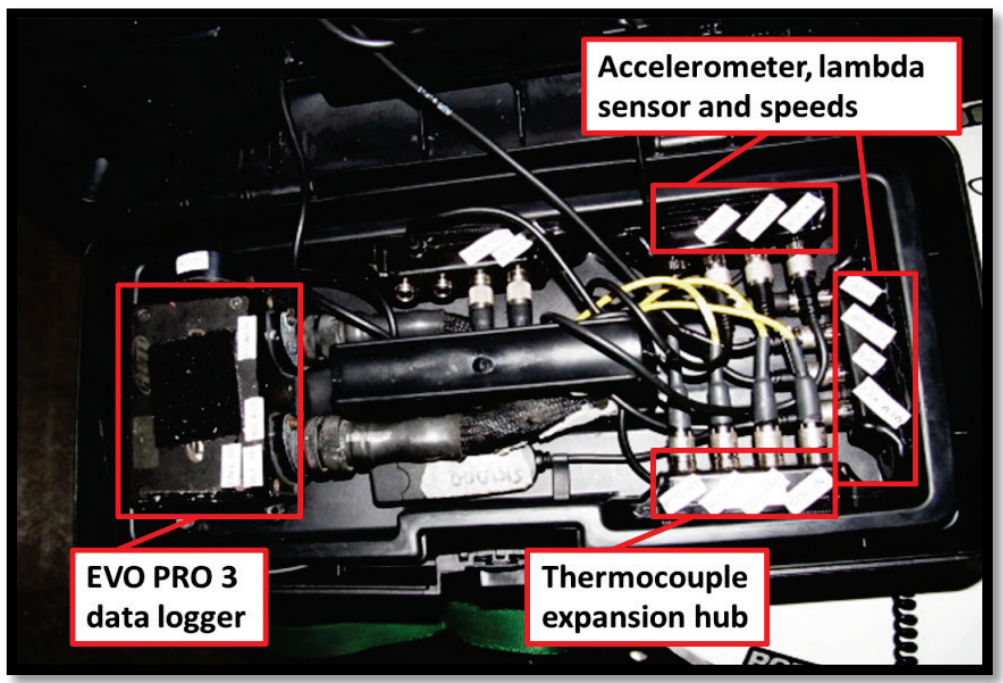

Figure 3.16: Data acquisition box detail

Specific instrumentation details for each snowmobile are provided in Table 3.2 through Table 3.5. 
Table 3.2:

Yamaha FX Nytro RTX Instrumentation

\begin{tabular}{|c|c|}
\hline \multicolumn{1}{|c|}{ Yamaha FX Nytro RTX } \\
\hline \multirow{3}{*}{ Temperatures } & -Three EGT's, (Thermocouple in Each Exhaust \\
Runner) \\
-Coolant Exiting the Engine (Thermocouple) \\
-Oil Temperature (Thermocouple) \\
-Data Logger Temperature (Internal Thermistor) \\
\hline \multirow{3}{*}{ Other Measurements } & -Engine RPM (Frequency from Sparkplug Wire) \\
& -Driveshaft Speed (Frequency from speed sensor) \\
& - Running Time (In Data Logger) \\
& -Battery Voltage \\
\hline
\end{tabular}

Table 3.3:

Ski-doo MX Z TNT Instrumentation

\begin{tabular}{|c|c|}
\hline \multicolumn{2}{|r|}{ Ski-doo MX Z TNT } \\
\hline Temperatures & $\begin{array}{l}\text {-Two EGT's (Thermocouple in Each Exhaust Runner) } \\
\text {-Coolant hot and cold (Thermocouples) } \\
\text {-Head Temperatures Mag and PTO (Thermocouples } \\
\text { around sparkplugs) } \\
\text {-Data Logger Temperature (Internal Thermistor) }\end{array}$ \\
\hline Other Measurements & $\begin{array}{l}\text {-Engine RPM (Optical Sensor on the Drive Clutch) } \\
\text {-Belt Speed (Optical Sensor) } \\
\text {-Driveshaft Speed (Frequency from speed sensor) } \\
\text {-Air to Fuel Ratio (Lambda sensor in Mid-pipe) } \\
\text {-Running Time (In Data Logger) } \\
\text {-Battery Voltage }\end{array}$ \\
\hline
\end{tabular}


Table 3.4:

Polaris 800 Rush Instrumentation

\begin{tabular}{|c|c|}
\hline \multicolumn{2}{|c|}{ Polaris 800 Rush } \\
\hline \multirow{2}{*}{ Temperatures } & -Two EGT's (Thermocouple in Each Exhaust Runner) \\
& -Coolant hot and cold (Thermocouples) \\
& -Data Logger Temperature (Internal Thermistor) \\
\hline \multirow{3}{*}{ Other Measurements } & -Engine RPM (Frequency from Sparkplug Wire) \\
& -Driveshaft Speed (Frequency from speed sensor) \\
& -Running Time (In Data Logger) \\
& -Battery Voltage \\
\hline
\end{tabular}

Table 3.5:

Arctic Cat F570 Instrumentation

\begin{tabular}{|c|c|}
\hline \multicolumn{2}{|c|}{ Arctic Cat F570 } \\
\hline \multirow{3}{*}{ Temperatures } & $\begin{array}{c}\text {-Two EGT's (Thermocouple in Each Exhaust Runner) } \\
\text {-Fan Air Temperatures in and out (Thermocouples) } \\
\text {-Head Temperatures Mag and PTO (Thermocouples } \\
\text { around sparkplugs) } \\
\text { Other Measurements }\end{array}$ \\
& $\begin{array}{c}\text {-Data Logger Temperature (Internal Thermistor) } \\
\text {-Driveshaft Speed (Frequency from speed sensor) } \\
\text {-Running Time (In Data Logger) } \\
\text {-Battery Voltage }\end{array}$ \\
\hline
\end{tabular}




\subsubsection{Thermocouples}

Type $\mathrm{K}$ thermocouples were used for this testing as they provide an accurate range from about $-200{ }^{\circ} \mathrm{C}$ to $+1250{ }^{\circ} \mathrm{C}$ with limits of error being $2.2{ }^{\circ} \mathrm{C}$ or $0.75 \%$ (whichever is greater) above $0{ }^{\circ} \mathrm{C}$ and $2.2{ }^{\circ} \mathrm{C}$ or $2 \%$ (whichever is greater) below $0{ }^{\circ} \mathrm{C}$. Thermocouples work on the basis of having two dissimilar metals that are connected in series which form a circuit and when the junctions are at different temperatures, an electromotive force (EMF) exists between the two metals. This EMF causes a small electric current to flow through the circuit. Type $\mathrm{K}$ thermocouples use a junction of Chromel(+) and Alumel(-) wires joined at the tip of the thermocouple.

The type $\mathrm{K}$ thermocouples used for this research were of three different configurations. The exhaust temperature thermocouples were $1 / 4$ " diameter type $\mathrm{K}$ stainless steel exposed tip. This configuration was used to have a durable but fast reacting thermocouple with the exposed tip. They were attached by drilling a hole in the exhaust runners on each cylinder and used a specialized hose clamp to secure it to the pipe. These clamps and EGTs can be observed in Figure 3.17. The second type used was a 1/8" diameter type $\mathrm{K}$ stainless steel ungrounded thermocouple which was used for the other temperature readings such as air and coolant temperature.

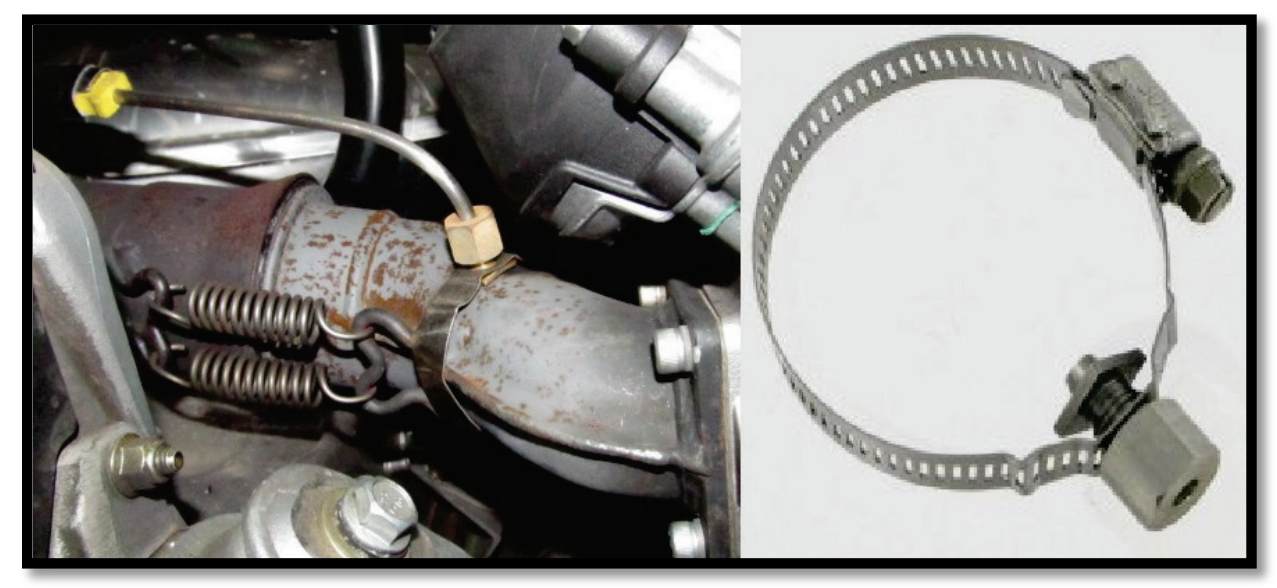

Figure 3.17: Thermocouple installed in exhaust and EGT clamp 


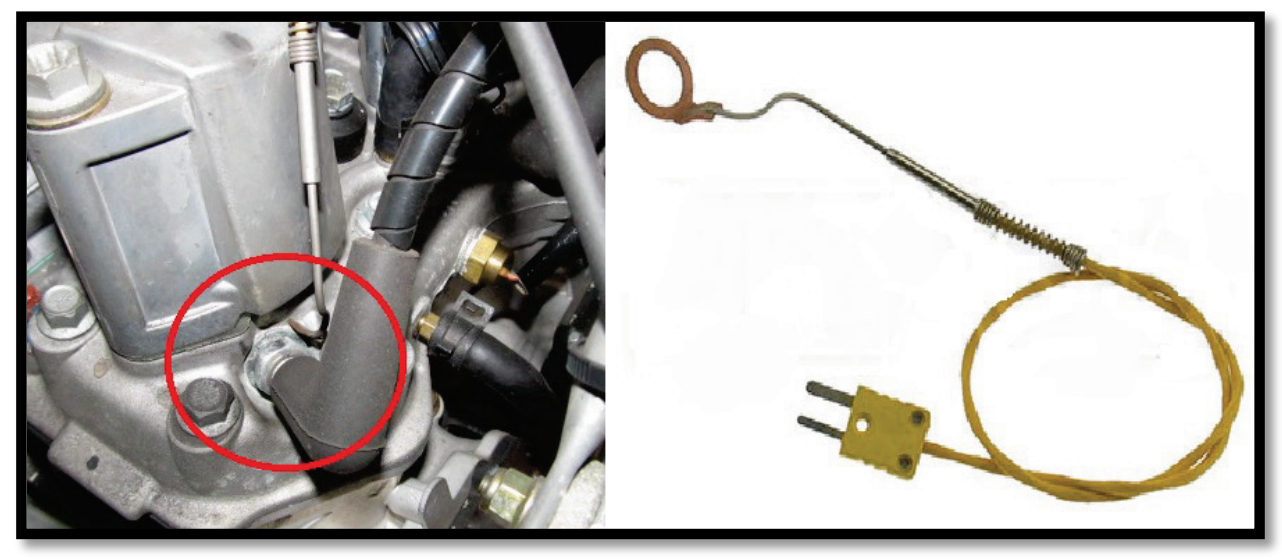

\section{Figure 3.18: Ring thermocouple installed on sparkplug}

The third kind of thermocouple used was designed especially for obtaining head temperatures. These thermocouple rings slip around the threads of the sparkplugs and rest against the head which is where it takes the temperature reading. These ring thermocouples can be seen in Figure 3.18. There was a thickness to the copper washer that goes around the spark plug, therefore the sparkplugs were machined down the same thickness as the washer. This was done so that the sparkplug would sit at the same depth in the cylinder and would not affect the performance of the engine.

\subsubsection{Optical Speed Sensor}

To obtain rotational speed without performing major modifications to the electrical system, optical speed sensors were used. These were purchased from Precision Auto Research. The sensors were installed through a thin sheet of metal using the locking nuts on the sensor housing. The sensors were powered by the data acquisition's 12 volt system and measured the rotational speed of the object by sensing the differences in reflectivity. The output from the sensor was a frequency signal that was then brought into the data acquisition system. 


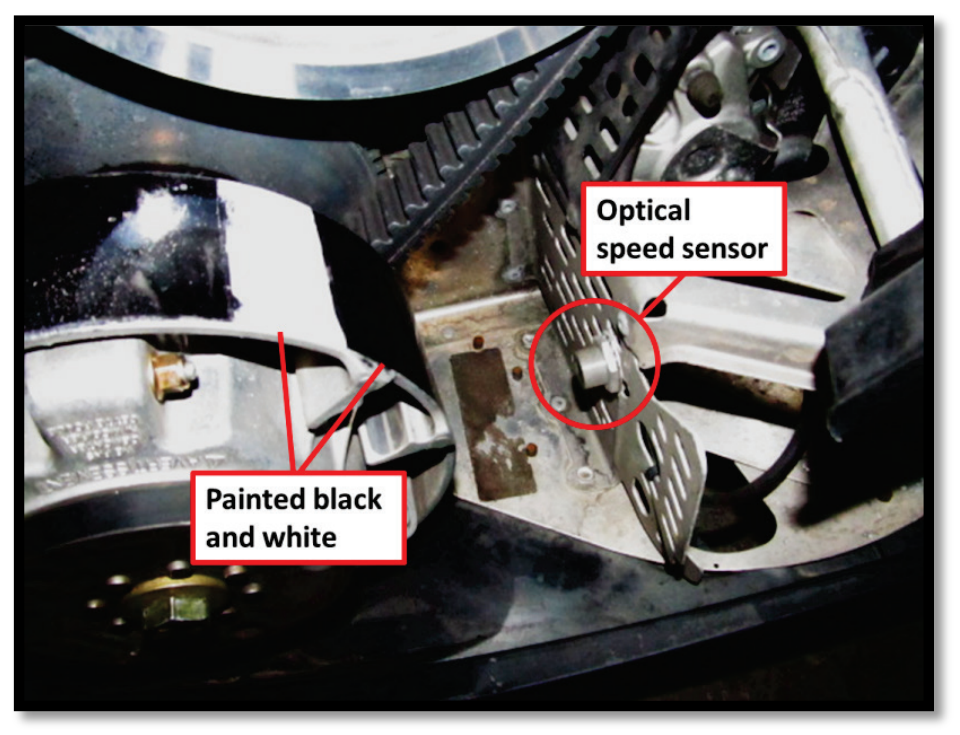

Figure 3.19: Optical speed sensor used to obtain speeds

\subsubsection{Lambda Sensor}

A lambda sensor was implemented on the Ski-doo to be able to monitor the AFR of the snowmobile while it was operating. The wideband sensor was a Bosch LSU 4.9 probe. This sensor measured the partial pressure of the oxygen in the exhaust compared to the stoichiometric level. Unfortunately because of the Ski-doo's lean calibration at idle, the lambda sensor was maxed at a value of 16:1 AFR for all test data. The data from the lambda sensor was however useful in other drivability testing that was performed with the snowmobile.

\subsection{Vehicle Data Acquisition System}

The data acquisition system used was from AIM Racing Data Power. This company specializes in making data acquisition and loggers that are standalone units and can be used in some of the harshest racing environments. For the cold-start tests, two different models, EVO3 Pro and EVO4 systems were used. Both systems were capable of taking the various measurements needed. 


\subsubsection{EVO3 Pro and EVO4}

Four units were purchased to instrument each snowmobile. The EVO4 units came equipped with five analog channels, integrated GPS module and tri-axial accelerometer. There were also two speed channels, a digital RPM channel and $16 \mathrm{Mb}$ of memory. It was operated with CAN bus outputs and inputs. CAN bus allowed microcontrollers and devices to communicate with message based protocol which was designed specifically for automotive applications. This is how expansion hubs could be added by just plugging the hub into one of the inputs. Figure 3.20 is a picture of both of the data loggers (AIM Racing Data Power 2011).

The important features of the EVO3 Pro system are $16 \mathrm{MB}$ of internal memory, eight configurable channels with sensors included with capability of expanding the channels through expansion hubs. The expansion hubs are where the GPS, lambda controller and extra thermocouples were input. EVO3 Pro was also operated on a CAN bus system. Figure 3.15 shows the EVO 3 system installed on the Ski-doo snowmobile.

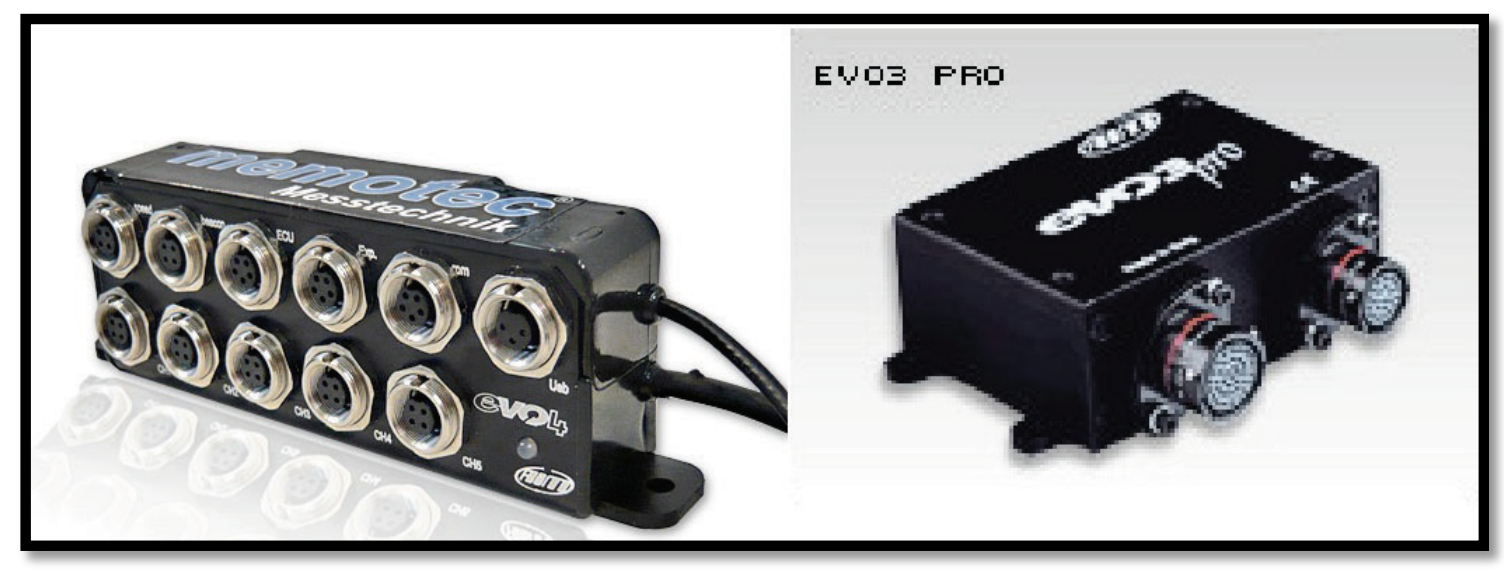

Figure 3.20: EVO4 and EVO3 Pro Data loggers

\subsubsection{Acquisition Rate}

The EVO systems were capable of sampling data at a frequency of up to 5000 hertz $(\mathrm{Hz})$. However using this high of frequency for most of the channels was 
unnecessary. Inputs such as temperatures, speeds, battery voltage and GPS information were all taken at a frequency of $10 \mathrm{~Hz}$.

\subsubsection{Start/Stop trigger}

The EVO systems had an automatic start and stop trigger. For this research, we used the RPM sensitive trigger. This trigger was set at 500 RPM so when the logger sensed that the RPM was above or below, it would switch to recording or idle respectively. The different runs were saved as different files on the internal memory of the EVO systems and as a backup, they were also recorded on a memory stick that was included with the system. The data loggers for the cold-start testing were powered by an external 12 volt deep cycle battery that was connected before each test. During the other testing done with the snowmobiles, the data loggers were powered by a smaller 12 volt battery that fit inside of the boxes or they were powered by the snowmobile's 12 volt system.

\subsubsection{Software}

To be able to communicate and setup the data logger systems, free software programs downloaded from the AIM Racing website was used. These programs were called Race Studio 2 version: 2.45.02 and RS2Analysis 2.45.02.

The Race Studio 2 software was used to setup each channel of data that was being collected. The sample frequencies, channel location, name/type of the channels, and calibration of the channels were all done in this software. There was a tab on this program where real-time updates of the channels were observed. This option was useful to make sure before and during each cold-start tests that each of the channels were working properly. When the tests were complete, Race Studio 2 had a tab that opened up all of the saved files on the data logger and the important files were selected and saved using a specific naming convention. For example the Arctic Cat test data from the $15^{\text {th }}$ cold-start test operating on E0 fuel at $0{ }^{\circ} \mathrm{F}$ on July $17^{\text {th }} 2011$ was 
ArcticCat_15E_EO_OF_06_17_11. The files were automatically saved in the RS2Analysis program where all of the data was observed.

In the RS2Analysis program, all of the channels were tabulated and selected to be displayed on the graph. This was useful to check and make sure the data was consistent. Multiple tests were overlaid to check for consistency between the tests. To further analyze the data, it was more useful to export the information into an Excel spreadsheet. There was a built-in function for exporting the data which was used to populate a spreadsheet at a frequency of $200 \mathrm{~Hz}$. At this frequency, all of the information was captured and the files did not get too large (less than 64500 lines).

\subsection{Emissions Analyzer}

A Semtech-DS five-gas analyzer, Figure 3.21, was used to measure exhaust emissions of the snowmobiles during the start-up process. Total hydrocarbons (THC) were measured using a flame ionization detector (FID), carbon monoxide (CO) and carbon dioxide $\left(\mathrm{CO}_{2}\right)$ concentrations were measured using a non-dispersive infrared (NDIR) detector, and the oxygen $\left(\mathrm{O}_{2}\right)$ was measured with an electrochemical oxygen sensor. The sampling rates of each of the three analyzers were slightly different but within the software were averaged to $1 \mathrm{~Hz}$ in the output file (Semtech-DS 2011).

Table 3.6 shows the measurement range, accuracy and resolution of the emissions analyzer. More detailed specifications on the Semtech-DS five-gas analyzer are included in Appendix A. 


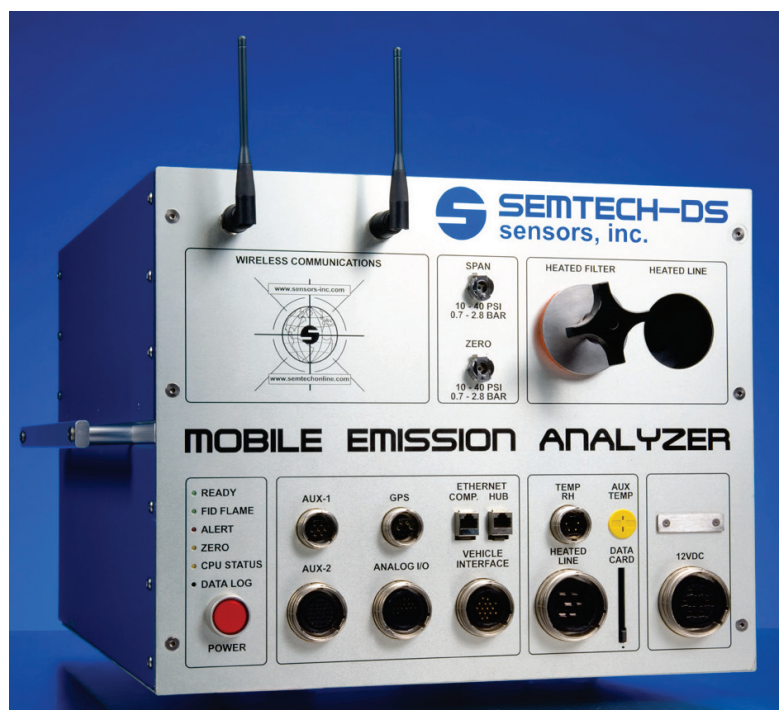

Figure 3.21 Sensors Inc. Semtech-DS five-gas emissions analyzer

Table 3.6:

Semtech DS emissions analyzer measurement ranges, accuracy and resolution

\begin{tabular}{|c|c|c|c|}
\hline Hydrocarbon & $\begin{array}{c}\text { Range of } \\
\text { Measurement }\end{array}$ & Accuracy & Resolution \\
\hline $\begin{array}{c}\text { Carbon } \\
\text { Monoxide }\end{array}$ & $0-40,000 \mathrm{ppmC1}$ & $\begin{array}{c} \pm 2.0 \% \text { of reading or } \\
\pm 100 \mathrm{ppmC1} \\
\text { (whichever is greater) }\end{array}$ & $10.0 \mathrm{ppmC1}$ \\
\hline Carbon Dioxide & $0-20 \%$ & $\begin{array}{c} \pm 3.0 \% \text { of reading or } \\
50 \text { ppm (whichever is } \\
\text { greater) }\end{array}$ & $10 \mathrm{ppm}$ \\
\hline Oxygen & $0-25 \%$ & $\begin{array}{c} \pm 3.0 \% \text { of reading or } \\
\pm 0.1 \% \text { (whichever is } \\
\text { greater) }\end{array}$ & $0.01 \%$ \\
\hline
\end{tabular}

\subsubsection{Flame Ionization Detector (Hydrocarbon Measurement)}

In normal operation of engines there is an incomplete combustion of the fuel which leads to hydrocarbons in the exhaust. There are many different kinds of hydrocarbons that could be output and to measure each type, an FTIR would have to be 
used. An easier and cheaper analysis of total amount of hydrocarbon compounds present in the exhaust is performed using a flame ionization detector (FID).

When a molecule of a hydrocarbon is introduced into a hydrogen-air flame, the molecule is pyrolyzed and the carbon and hydrogen are oxidized. During this oxidation process, ions are produced through complex chemi-ionization reactions. It is known that the number of ions produced depends on the number of carbon atoms in the molecule. The ions produced from the carbon atoms are detected using a metal collector which is biased with a high DC voltage. The ion generated current is directly proportional to the number of ions produced and in turn the number of carbon atoms present in the sampled gas. (Cambustion FID 2012)

\subsubsection{Non-Dispersive Infrared $\left(\mathrm{CO} / \mathrm{CO}_{2}\right)$}

A non-dispersive infrared measuring technique is based on the principle of absorption of infrared radiation by gases $\left(\mathrm{CO} / \mathrm{CO}_{2}\right)$. The different gases absorb the infrared radiation at different wavelengths which the IR detector senses. The reason why the instrument is called a non-dispersive infrared analyzer is because it uses the total absorption over a given wavelength. Therefore, no dispersing elements like prism or grating is required to resolve detailed spectral lines. (Cambustion NDIR 2012)

\subsection{Test Matrix}

A total of eighteen valid tests were conducted on each snowmobile with the two different fuels and three different temperatures. The following table outlines the different tests conducted. To decrease the total number of tests, all four of the snowmobiles were cold-soaked, tested and cleaned out all as a set. Three different tests at each temperature and fuel combination were performed to determine the repeatability of the procedure and make sure that the order of starting the snowmobiles did not affect the emissions. A different snowmobile was started first for each test sequence at a given temperature. 
Table 3.7:

Test matrix of cold-start tests of each snowmobile

\begin{tabular}{|c|c|c|c|}
\hline Fuel/Temperature & $\mathbf{2 0}{ }^{\mathbf{o}} \mathbf{F}$ & $\mathbf{0}{ }^{\circ} \mathbf{F}$ & $\mathbf{- 2 0}^{\mathbf{o}} \mathbf{F}$ \\
\hline \multirow{3}{*}{ E00 } & Cold-start 1 & Cold-start 1 & Cold-start 1 \\
\cline { 2 - 4 } & Cold-start 2 & Cold-start 2 & Cold-start 2 \\
\cline { 2 - 4 } & Cold-start 3 & Cold-start 3 & Cold-start 3 \\
\hline \multirow{2}{*}{$\mathbf{E 1 5}$} & Cold-start 1 & Cold-start 1 & Cold-start 1 \\
\cline { 2 - 4 } & Cold-start 2 & Cold-start 2 & Cold-start 2 \\
\cline { 2 - 4 } & Cold-start 3 & Cold-start 3 & Cold-start 3 \\
\hline
\end{tabular}

\subsubsection{Temperatures and Fuels}

To test the effects of the addition of ethanol to the fuel during the cold-start operation of the snowmobiles, different temperatures were used. Snowmobiles are normally operated in colder temperatures during the winter so the temperatures the tests were performed at were all below freezing. The three temperatures were $-20^{\circ} \mathrm{F}, 0^{\circ} \mathrm{F}$, and $20^{\circ} \mathrm{F}$. These temperatures are representative of normal starting temperatures of snowmobiles if they are left outside overnight in the middle of winter.

The two different fuels used were a pure gasoline (E0) for a baseline measurement and a gasoline and ethanol mix (E15) as the fuel being investigated. The analysis of the fuel was performed by Southwest Research Institute (SWRI). The fuels had an octane rating of 87 and $91(\mathrm{R}+\mathrm{M} / 2)$. The Yamaha and Arctic Cat were operated on the 87 octane fuel and the Ski-doo and Polaris were operated on 91 octane fuel which is what each manufacture recommended for their snowmobiles.

\subsubsection{Pulls/Time to Start}

During the cold-start tests, the snowmobiles needed to be started the same way each time to remove that variable from test to test. To ensure that the number of pulls was similar and repeatable, the number of pulls to start or the length of engine cranking was 
recorded. The Yamaha snowmobile only had an electric start so the time to start was recorded. The Polaris and Ski-doo were electronically fuel injected so only the number of pulls was recorded. The Arctic Cat was carbureted and therefore the number of pulls and time that the choke was on were both recorded. These were all recorded manually and input into a spreadsheet for analysis.

\subsubsection{Other Recorded Parameters}

To ensure that the snowmobiles were started at the same temperature for each test, the temperatures and humidity of the cell were recorded when each snowmobile was started. These were recorded using a residential weather station. Figure 3.22 shows the weather station used. This weather gauge is not NIST traceable so it was only used as a reference and recorded in the same spreadsheet as the number of pulls and time to start was recorded. All of the test information was recorded by hand on a sheet that was made specifically for the cold-start tests. An example of these sheets filled out can be observed in Appendix A.5.

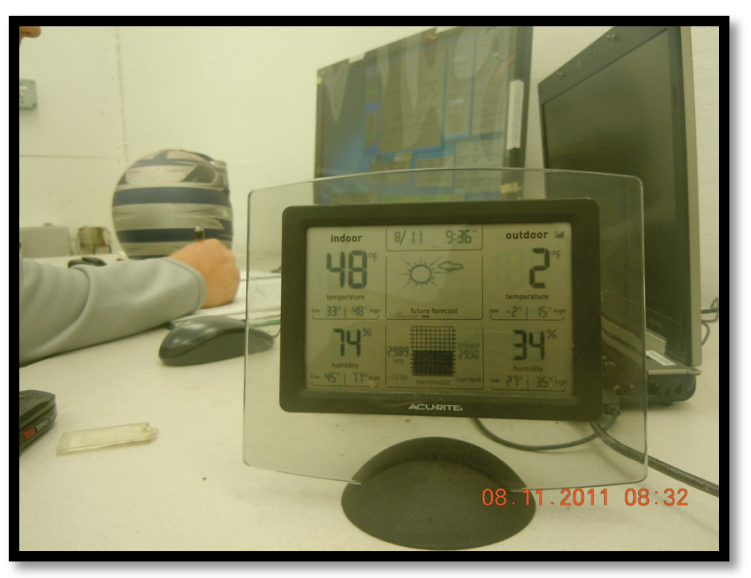

Figure 3.22: Acu-Rite weather station

\subsection{Test Procedure}

To ensure tests were consistent for each snowmobile at each fuel and temperature, a detailed test procedure was followed. Procedures were made for each part of the test including; the engine cleanout procedure, the cold-soaking procedure, starting procedure 
and the fuel change procedure. Some of these tasks were recorded for each test and others were repeated the same for each test without having a log of them.

\subsubsection{Engine Cleanout}

To start the snowmobiles at the same condition for each cold-start test, an engine cleanout procedure was produced. For this cleanout, each snowmobile was operated for a certain period of time going through different phases of warm up and operation. The procedure described below was produced through trial and error with feedback from many people including the manufactures. Figure 3.23 below is a satellite picture from Google Earth. The picture shows the parking lot where the cold-start facility was located. In this parking lot, the snowmobiles were brought out from the rear of the trailer and were warmed up. Then each snowmobile was driven around the parking lot following the path shown in Figure 3.23. The snowmobiles were then loaded back into the trailer. The specific cleanout procedure is described below. 


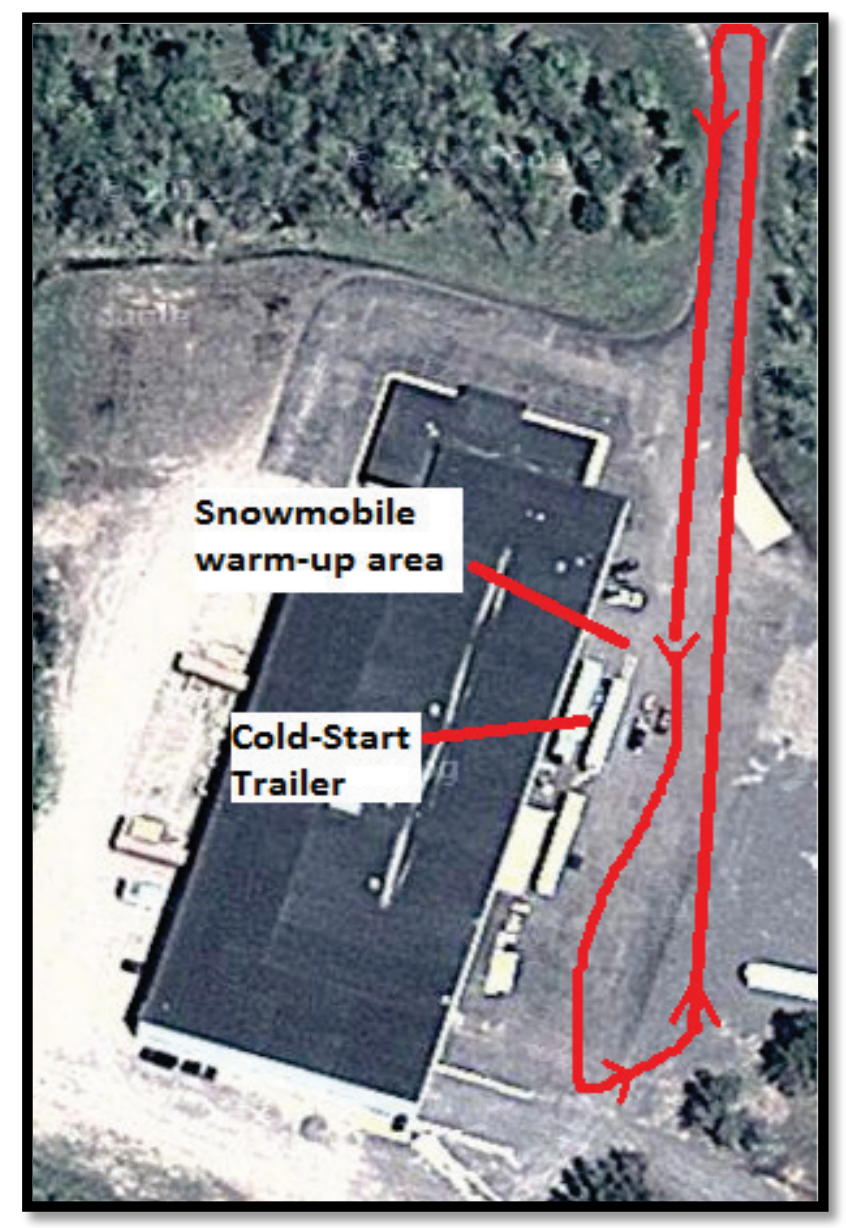

Figure 3.23: Satellite picture of parking lot where snowmobiles were cleaned out

1. Start the snowmobiles and let them idle for a few seconds and back them out of the cold-start trailer to the warm-up area. Let the snowmobiles warm up for 5 minutes idling in warm-up area.

2. Prop the rear (track) of each snowmobile up so the track could be spun with trackstand (Figure 3.24).

3. Spray the track and rear suspension with water to lubricate the slides and keep them cool.

4. Apply enough throttle to engage the CVT clutches and start spinning the track.

5. Spin the track at this throttle position for 2 minutes to warm the track and snowmobile up at same time. 
6. After these 2 minutes blip the throttle several times for 1 minute bringing the engine speed up to $75 \%$ of the maximum RPM of the snowmobile.

7. Let the snowmobile idle down then apply the throttle slowly until the track starts spinning and then hold the throttle wide open until the snowmobile reaches maximum engine speed. Repeat this 4 times.

8. Remove track-stand from rear of the snowmobile and put safety gear on to drive the snowmobile through parking lot to complete clean-out procedure.

9. Drive snowmobile around course shown in Figure 3.23 applying significant but reasonable throttle for test conditions. In the long straight run, full throttle is needed to be obtained to allow for the snowmobile to clean all of the un-burned fuel out of the engine and reach maximum engine speed. Repeat this for 5 total laps.

10. Stop between each lap to spray the track and rear suspension with water to lubricate the slides.

11. Load the snowmobiles back into the cold-start facility to cool down before being cold-soaked.

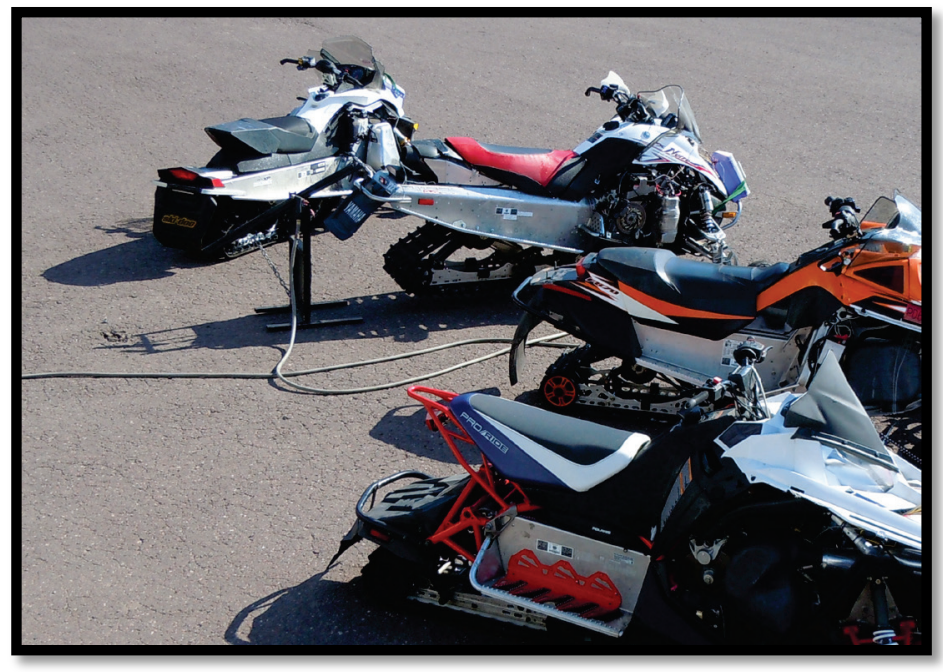

Figure 3.24: Example of Yamaha snowmobile using the track-stand 


\subsubsection{Cold-soaking}

With having four snowmobiles being brought up to operating temperature, there was a lot of heat being given off of the snowmobiles in the cold-start trailer. Therefore after the snowmobiles were cleaned out, they were all loaded into the trailer and shut off with fans blowing in the front of the cell and the back doors open to bring the snowmobiles down to the ambient temperature. This was done to conserve diesel fuel being used by the refrigerator to cool the test cell. The typical time it took for the vehicles to reach a steady state temperature for the $-20^{\circ} \mathrm{F}$ set point was 12 hours. The warmer set points required significantly less time to reach steady state. The procedure for coldsoaking the snowmobiles is described below.

1. Bring snowmobiles in trailer after clean out. Turn fans on in front of trailer and leave the back doors open to allow heat and exhaust fumes to be removed. Leave doors open for 1 hour.

2. Shut all doors to cold-start cell and place rag in exhaust fan to seal hole to outside air.

3. Turn refrigerator for test cell on and wait until it goes through its start sequence. Set the temperature to desired set point $\left(-20^{\circ} \mathrm{F}, 0{ }^{\circ} \mathrm{F}, 20^{\circ} \mathrm{F}\right)$.

4. Let the refrigerator run for at least 12 hours.

5. After letting the snowmobiles soak, check the temperature gauge that it is within 3 degrees of set point. Do the same thing for the EVO systems to make sure the snowmobiles are cold-soaked all the way to the set point.

6. Make sure that the refrigerator has not recently gone into defrost mode.

7. If all temperatures are acceptable, move forward with cold-start test. If they are not, wait longer until they are acceptable.

\subsubsection{Cold-Starting procedure}

The starting procedure was basically the same for each snowmobile but before the round of tests was started the emissions analyzer needed to be warmed up, stabilized, zeroed and spanned. When tests were going to be taken on consecutive days, the Semtech 
DS was left on between tests to keep all the internal analyzers up to temperature $\left(191^{\circ} \mathrm{C}\right)$. If the Semtech DS was not on from the previous test, the analyzer needed to be turned on and warmed up and stabilized for at least one hour. During this hour of warm-up, the FID flame would be lit so it could also stabilize for at least 20 minutes. When the emissions analyzer was warmed up and stable, the zero and span functions were performed. The zeroing was done with ambient air that was pulled from outside of the trailers from the outside air. After this was complete a quad blend of gases was spanned which the concentrations can be seen in Table 3.8. The zero and span functions were performed before the test sequence and at the conclusion of each test sequence. The zero and span was not performed between each snowmobile. Further procedures for operating the Semtech DS can be observed in Appendix A. The following is the rest of the cold-start procedure which is a two person job; one controlling the emissions analyzer and one starting the snowmobiles.

Table 3.8:

Quad blend gas used to span the Semtech DS before and after each test

\begin{tabular}{|c|c|}
\hline Quad Blend Gas & Concentration \\
\hline $\mathrm{CO}$ & $6.127 \%$ \\
\hline $\mathrm{CO}_{2}$ & $16.48 \%$ \\
\hline $\mathrm{THC}$ & $3016 \mathrm{ppmC} 3$ \\
\hline $\mathrm{NO}$ & $2103 \mathrm{ppm}$ \\
\hline
\end{tabular}

1. Connect the exhaust of the snowmobile to the flexible hose with the other end connected to the exhaust fan.

2. Make sure sample probe is in the correct position inside the exhaust of the snowmobile to be tested. Then connect external heated filter to the sample probe via Swagelok fitting and prop the heated filter up in correct position.

3. Leave heated sample line off of the heated filter and sample the room air to make sure there is no residual exhaust left in room.

4. When room air sample is complete, hook the heated sample line to the heated filter and make sure all connections are tight. 
5. Start sampling the emissions and start the snowmobile. Record the number of pulls (Arctic Cat, Polaris and Ski-doo) or time it takes for engine to actually fire (Yamaha).

6. For the Arctic Cat, have the person controlling the emissions analyzer time and signal to the person starting the snowmobile when to shut off the choke.

7. Let the snowmobiles idle without touching throttle for 3 minutes to be able to obtain trends from emissions analyzer and data acquisition system.

8. After the 3 minute test, shut the engine off and remove sample line and heated filter from sample probe. Stop recording data on the Semtech DS but continue to sample room air to reduce the concentration of emissions attached to the inside of the sample line. Observe THC concentration and stop sampling room air when it is less than $2 \%$ of the analyzer range.

9. If all temperatures are still acceptable in the cell continue and repeat above procedure for the next snowmobile until all snowmobiles are tested.

10. Rotate the order of snowmobiles started to test to see if there is a difference in emissions with order of snowmobiles started.

11. When finished with all tests, remove snowmobile from trailer and perform cleanout procedure and prepare for next cold-start test.

\subsubsection{Fuel change procedure}

The following describes how to change the fuel of the snowmobiles to minimize the dilution of one fuel with the other.

1. Syphon all fuel out using an approved fuel syphon into a waste fuel container.

2. Tip snowmobile to one side to get all fuel in one corner of fuel tank and use syphon again to remove as much fuel as possible

3. Start snowmobile outside and let it idle until it stops running from not having enough fuel.

4. Try starting snowmobile after it dies to ensure there is no fuel left in the fuel tank or carburetors/injectors. 
5. Fill with new fuel and clean snowmobile engine out for cold-start using the new fuel following the procedure listed in 3.7.1.

\subsubsection{Complications and issues with Cold start testing}

In the early stages of the cold start testing, there were many issues and struggles that occurred. Originally there were no written procedures so it was very hard to be consistent from test to test with accurate results. In addition, a formal procedure does not exist from the Environmental Protection Agency (EPA) for these types of vehicles. The following explains some of the issues that arose with the snowmobiles during the coldstart testing and the solution that was used.

There were very few issues with the Yamaha, Ski-doo, and Polaris as their engine control strategies are fairly advanced so there were not a lot of variables that could be changed by the operators. For the Yamaha, the only issue with the four-stroke engine was that since there was no pull-start, the electrical starter had to be used. At the colder temperatures, the battery voltage would drop and therefore change how fast the engine would turn over from test to test. The longer, slower cranking time modified the initial emissions so the original solution was to leave a battery tender on the battery while the snowmobile was cold soaked. This solution worked initially but the battery tender was not meant for use at very cold temperatures and malfunctioned and did not keep a charge at colder temperatures. The final solution was to use a separate warm battery and use jumper cables to jump the battery. This allowed the engine to crank over more consistently and produce more accurate results.

The Ski-doo had very few issues as well. One of the first issues was that an optical sensor was used to obtain engine speed which used black and white differences on the clutch to sense speed. Sometimes when the snowmobile would be cleaned out at warmer temperatures and then cooled down to the test temperature, frost would form on the clutch. This would prohibit the optical sensor from seeing that there was a difference in color and therefore, no engine speed would be sensed to start the data acquisition. The solution to this problem was to use a rag and wipe the frost off before the test. The other 
issue that arose was that to fit all of the snowmobiles into the trailer, the Ski-doo needed to be backed in. By backing the Ski-doo in, the belt was at different levels in the clutches and therefore, different loads were applied to the engine during the next cold-start test. If increased load was applied to the engine at startup, the calibration added fuel to produce a consistent idle speed. To solve this issue, a procedure was followed to put the engine back into forward operation and rev the engine up enough to engage the clutches and place the belt in the same position each time.

The Polaris had a different type of issue when compared to the other snowmobiles. The way the Polaris was designed was to inject plenty of oil when the snowmobile was at idle and therefore if the engine was not cleaned out properly, the spark plugs would get too much oil built up on them and foul. This was thought to be a problem because of starting the snowmobile for 3 minutes at cold conditions and then shutting it off without getting the engine completely warm and then when restarting the engine, one of the plugs would foul. Almost every fouled plug was after the cold-start test was over, therefore when removing the snowmobile from the test cell; care was used to get the engine up to operating temperature. Fewer plugs were fouled when care was used to slowly warm the engine up without letting it idle for too long.

The Arctic Cat was found to be a very difficult snowmobile to test because of the many variables that could be changed. The engine was carbureted which meant that for the starting operation, there was a choke lever that could be switched to allow for more fuel to be added. Originally there was no procedure for the amount of time the choke would be operated for and the test results varied significantly. The first solution for this was to start the engine with full choke on and turn the choke off when the engine RPM dropped below a certain value after being started. This was also found to be inconsistent between tests. The solution that worked was to test and come up with a time to turn the choke off and then for the following tests, use the same amount of time for each fuel. This was a trial and error which required additional tests to be taken but in the end, the test results were more consistent. Some of the other issues that were found with the Arctic Cat were that the speed and power used to pull the snowmobile over with would 
change the emissions, the idle speed was not correctly set to begin with, and the snowmobile would stop running during some of the tests because of the carburation not being able to compensate.

There were also issues that were found with the cold-start test cell and surrounding equipment. One major issue was that the tests were performed during the spring and summer months and since the cold test cell was outside in the environment, the thermal and solar heat load was causing issues. The heat would make it hard for the refrigerator cooling the test cell to keep the cell at a constant cold temperature. This caused the testing to be a lot more expensive because of diesel fuel and take a lot longer because the refrigerator could not hold the temperature and would go into a defrost mode. One issue that could only be solved with being very careful was with the equipment becoming very brittle at cold temperatures. Some of the cables and wires that were being used for the testing were beginning to crack because they were not flexible anymore and the coating on the wires would crack when moved. Therefore care was used when moving and getting the equipment into place and the cracked and damaged equipment was repaired or replaced. 


\section{Chapter 4 Results}

In this chapter, the results from the four snowmobiles are discussed. The average traces of three or more tests for each fuel and temperature combination are shown to represent the results. To show repeatability, a method of using at least three consistent tests was employed and averaged together so the average results could be compared. Emissions and engine data are presented for each snowmobile comparing all three temperatures and both fuels on each plot. Comparisons and trends for all four snowmobiles are then presented. When the temperatures for the cold-start tests were originally proposed, the English system of Fahrenheit $\left({ }^{\circ} \mathrm{F}\right)$ was used. However in this report, all of the results and explanations are referenced in the SI units of Celsius $\left({ }^{\circ} \mathrm{C}\right)$. The tests are labeled as $20^{\circ} \mathrm{F}, 0{ }^{\circ} \mathrm{F}$, and $-20^{\circ} \mathrm{F}$ which corresponds to $-6.67^{\circ} \mathrm{C},-17.78^{\circ} \mathrm{C}$, and $-28.89^{\circ} \mathrm{C}$.

\subsection{Test Validity with Repeatability}

A total of 202 individual cold start tests were conducted. To reduce time and cost, some of the tests were run with all four snowmobiles at once. However several tests were conducted with only one or two snowmobiles being retested because of issues with previous tests. A spreadsheet of the hand-recorded information from each snowmobile is located in Appendix A for reference. An example of the three tests and an average to show repeatability for emissions is shown in Figure 4.1 for the Yamaha at $-20^{\circ} \mathrm{F}$ and E15 fuel. Three individual tests were time aligned and plotted to show there was little variability between them. Figure 4.2 is a plot of three individual tests of the engine speed from the Yamaha snowmobile at $-20^{\circ} \mathrm{F}$ and E15 fuel. The data acquisition automatically started recording the data at the same time for each test based on engine speed so time aligning was not necessary.

The following sections discuss the details of each snowmobile explaining the emissions and engine data. Not all of the parameters will be shown and explained in these sections but the data that is not included can be observed in Appendix A.6 thru Appendix 
A.32. The objective of this research was not to compare the snowmobiles against each other but rather to compare how each snowmobile responded to the addition of ethanol in the fuel.

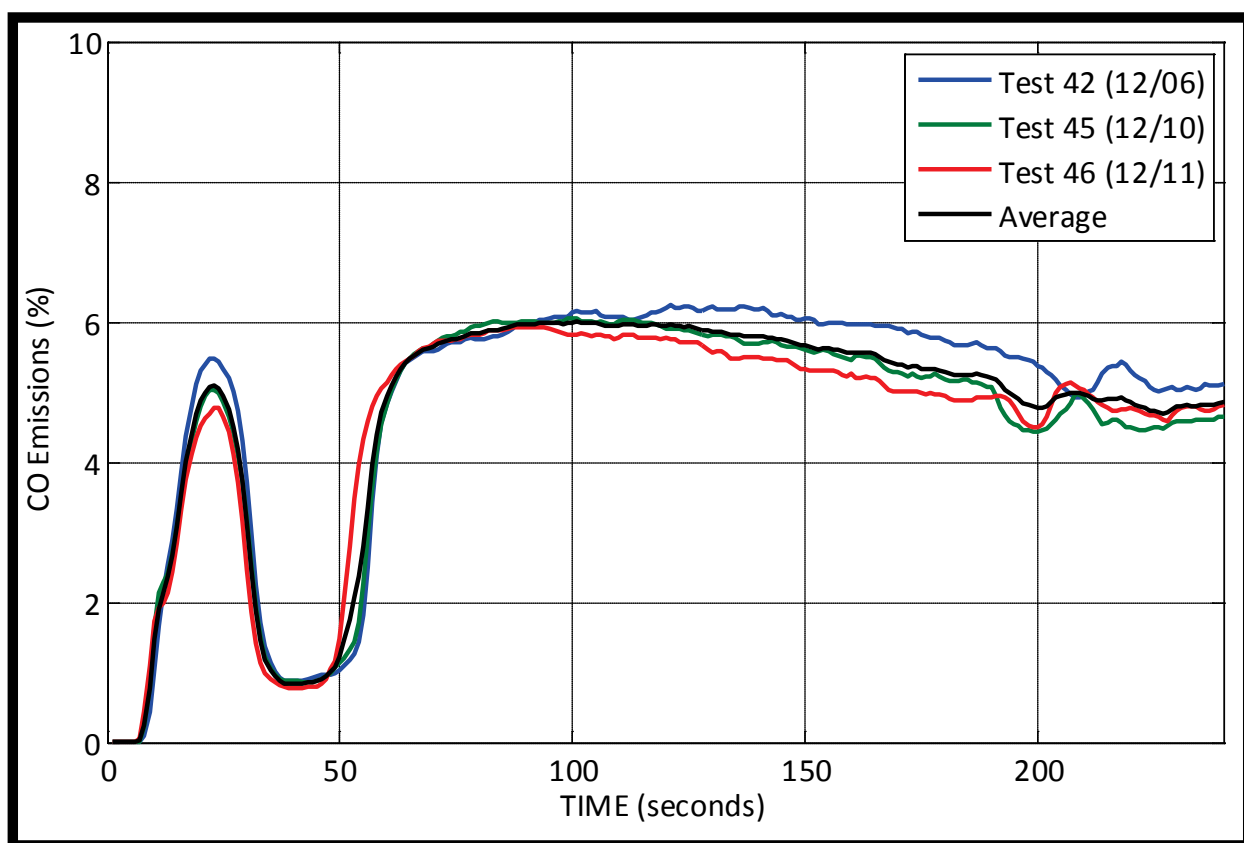

Figure 4.1: Yamaha $\mathrm{E} 15-20^{\circ} \mathrm{F}$ individual tests and average of $\mathrm{CO}$ emissions

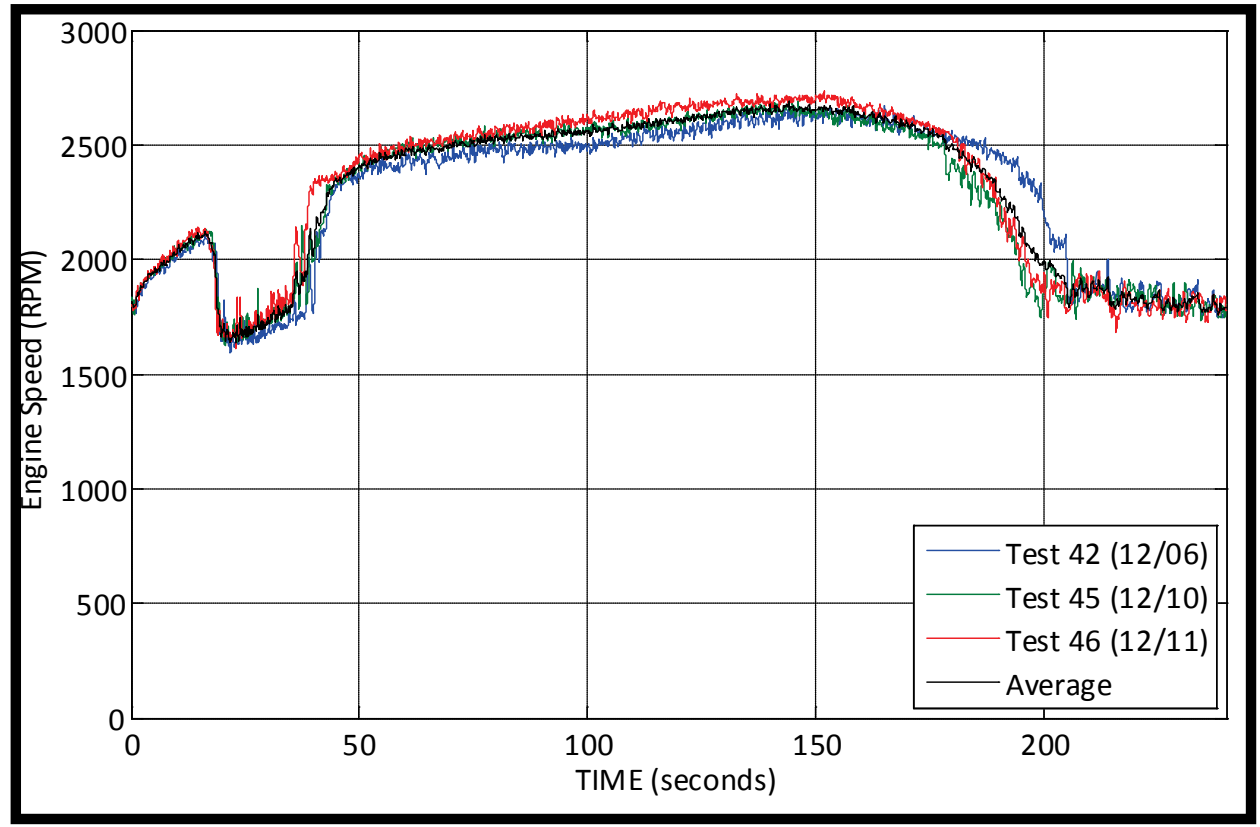

Figure 4.2: Yamaha $\mathrm{E} 15-20^{\circ} \mathrm{F}$ individual tests and average of engine speed 


\subsection{Yamaha FX Nytro RTX}

The Yamaha RTX's performance was very consistent throughout the cold-start tests. A total of 36 tests were taken to complete at least 3 tests at each fuel and temperature combination. This engine operated on an open loop control system so there was no compensation for the addition of ethanol to the fuel. Shown in Table 4.1 are single value representative averages of the whole test periods with percent differences to provide a better idea of which fuel had higher emissions. Figure 4.3 is a bar chart of the percent change in the emissions when the fuel was changed to E15. The data shows that between each fuel at each temperature, $\mathrm{CO}_{2}$ increased between $4.5 \%$ and $7 \%$ for $\mathrm{E} 15$ with CO decreasing $12 \%$ to $19 \%$ and THC decreasing $20 \%$ to $23 \%$ for E15. The plots where each of these averages was obtained from are shown after the table. The cranking time for the starter before the engine fired was also recorded. The averages of the tests are in the last column of Table 4.1. The only significant difference in times to start was at $-20^{\circ} \mathrm{F}$ where E15 took 6 seconds and E0 took approximately 3.5 seconds. Figure 4.4 shows how the cranking time increases as the temperature decreases

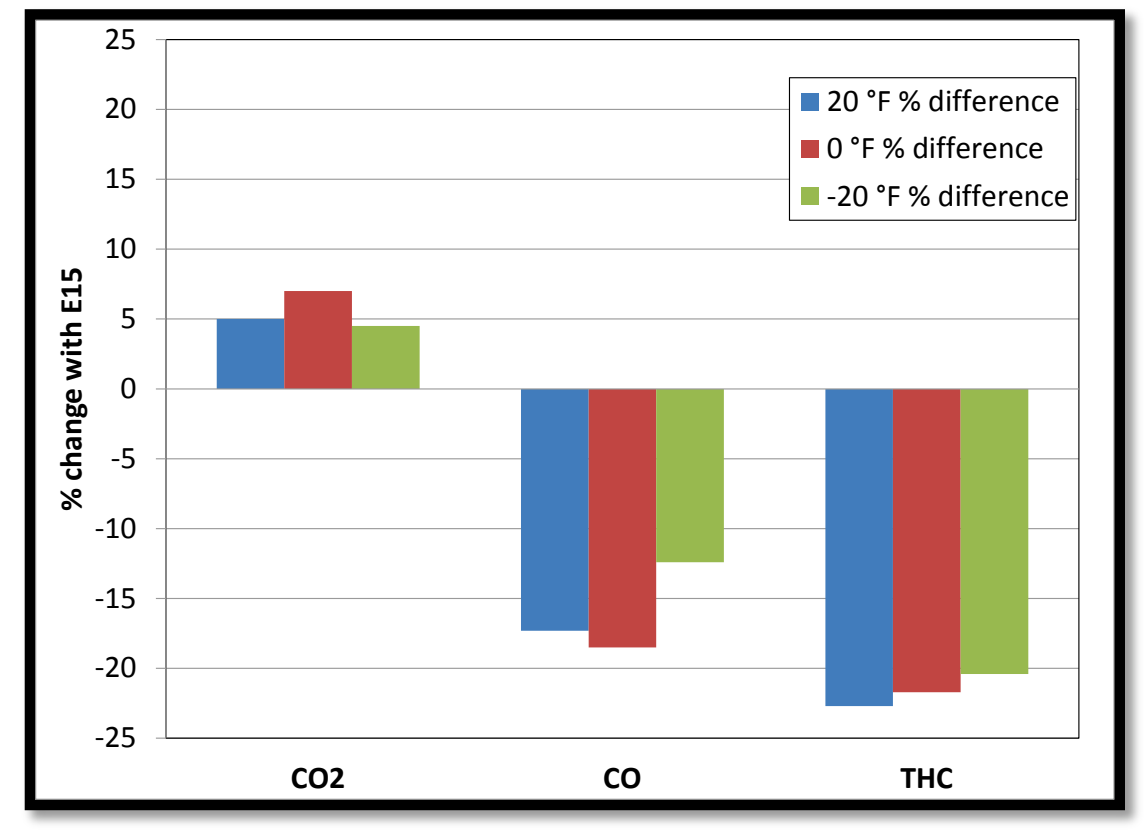

Figure 4.3: Percent change of Yamaha emissions when changing to E15 
Table 4.1:

Yamaha average results of emissions and starting data

\begin{tabular}{|c|c|c|c|c|}
\hline & $\begin{array}{l}\mathrm{CO} 2 \\
(\%)\end{array}$ & $\begin{array}{l}\text { CO } \\
\text { (\%) }\end{array}$ & $\begin{array}{c}\text { THC } \\
\text { (ppm) }\end{array}$ & $\begin{array}{l}\text { Cranking } \\
\text { time (sec) }\end{array}$ \\
\hline E0 $20^{\circ} \mathrm{F}$ & 8.69 & 5.73 & 9445.26 & $\sim 1.33$ \\
\hline E15 $20^{\circ} \mathrm{F}$ & 9.12 & 4.74 & 7297.40 & $\sim 2$ \\
\hline $\begin{array}{c}20^{\circ} \mathbf{F} \\
\text { difference }\end{array}$ & $5.0 \%$ & $-17.3 \%$ & $-22.7 \%$ & $0.66 \mathrm{sec}$ \\
\hline E0 $0{ }^{\circ} \mathrm{F}$ & 8.61 & 5.63 & 10684.94 & $\sim 2.67$ \\
\hline $\operatorname{E15~} 0^{\circ} \mathbf{F}$ & 9.21 & 4.59 & 8365.81 & $\sim 2.5$ \\
\hline $\begin{array}{c}\mathbf{0}^{\circ} \mathbf{F} \\
\text { difference }\end{array}$ & $7.0 \%$ & $-18.5 \%$ & $-21.7 \%$ & $-0.17 \mathrm{sec}$ \\
\hline EO $-20^{\circ} \mathbf{F}$ & 8.75 & 5.33 & 15622.17 & $\sim 3.5$ \\
\hline E15 -20 ${ }^{\circ} \mathrm{F}$ & 9.14 & 4.67 & 12440.63 & $\sim 6$ \\
\hline $\begin{array}{c}-20{ }^{\circ} \mathbf{F} \\
\text { difference }\end{array}$ & $4.5 \%$ & $-12.4 \%$ & $-20.4 \%$ & $2.5 \mathrm{sec}$ \\
\hline
\end{tabular}

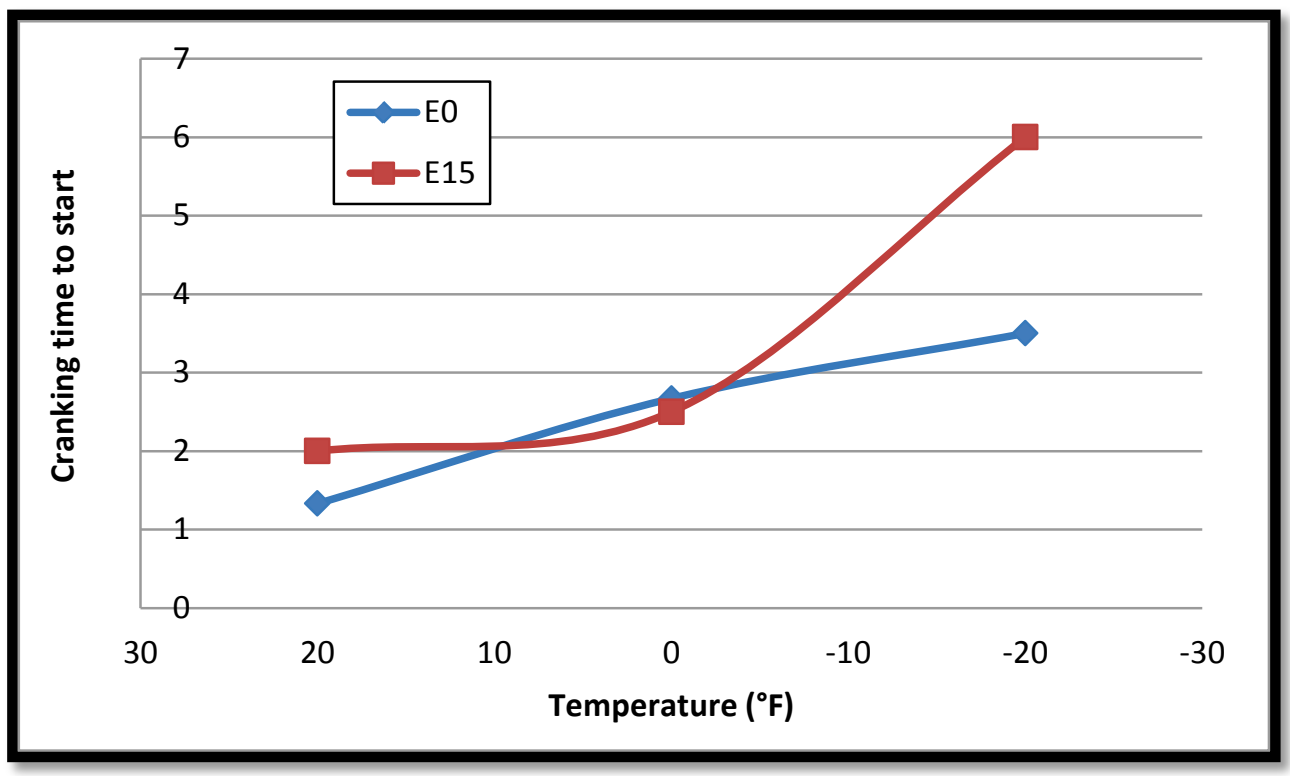

Figure 4.4: Average Yamaha cold-start cranking time required for the engine to start 


\subsubsection{Yamaha Emissions}

The first emissions constituent studied was $\mathrm{CO}_{2}$ from the cold-start tests, shown in Figure 4.5. The trend that can be observed was that all of the $\mathrm{CO}_{2}$ concentrations increased in the beginning of each test to a peak of around 9 to $10 \%$, then decreased to 8 or $9 \%$ and then slowly increased and leveled off between 9 and $10 \%$ by the end of the 240 seconds. There was a significant difference between the two fuels at $20^{\circ} \mathrm{F}$. In the beginning, the E0 fuel had a higher output of $\mathrm{CO}_{2}$ but then after approximately 30 seconds, E15 had a higher output of $\mathrm{CO}_{2}$. The other two temperatures also followed this pattern with $-20^{\circ} \mathrm{F}$ showing an even larger difference during the steady-state portion of the test. $\mathrm{CO}_{2}$ emissions are directly related to fuel consumption and combustion efficiency. As the engine stabilized for each cold-start test, E15 $\mathrm{CO}_{2}$ emissions exceeded those of E0. Perhaps an increase in fuel flow rate for E15 was required to satisfy the engine idle calibration set-point. Note that each temperature set had the same basic form regardless of the fuel. The trends in this plot can be explained further with plots of engine speed and exhaust gas temperature, shown later in this section.

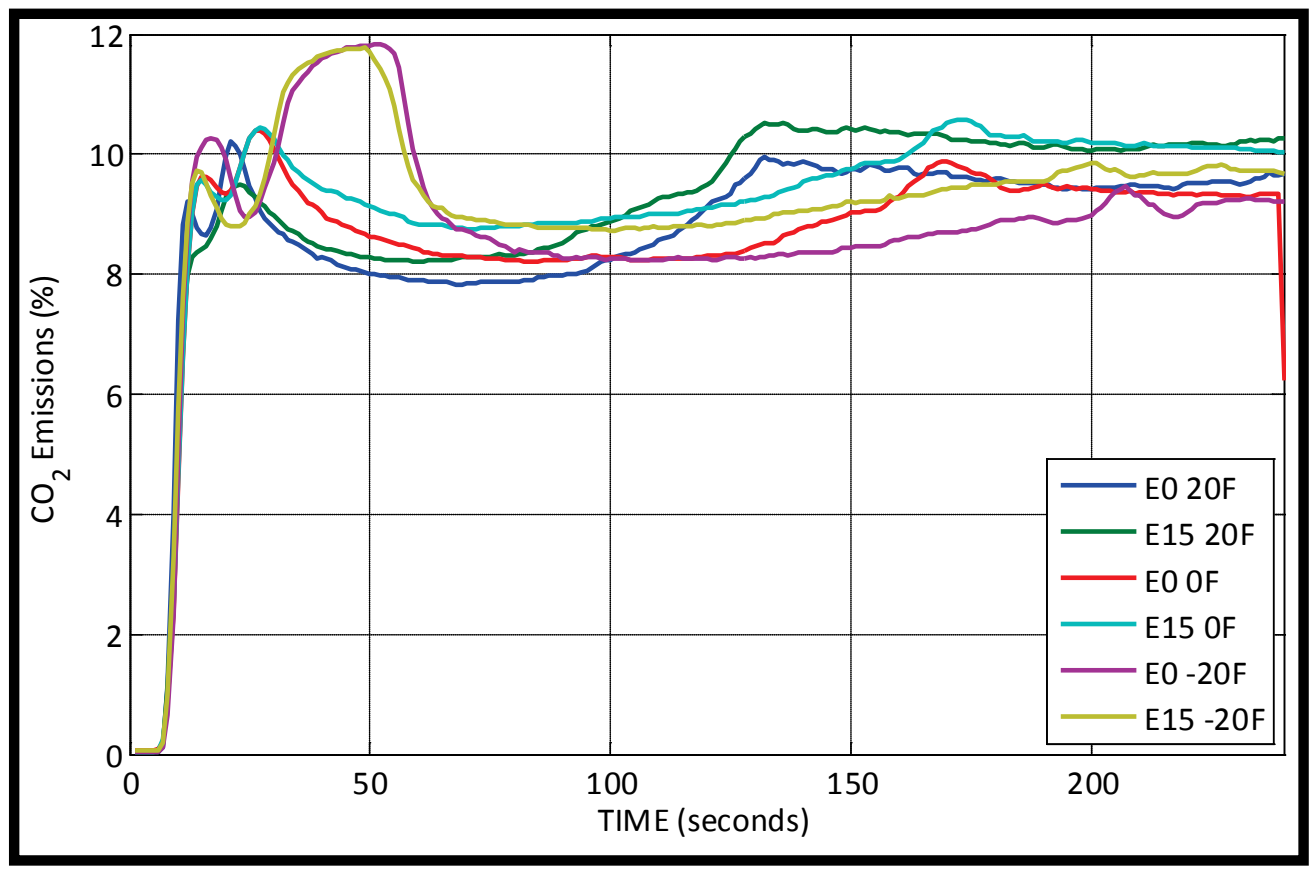

Figure 4.5: Average Yamaha cold-start $\mathrm{CO}_{2}$ emissions 
The second constituent from the exhaust observed was the CO. CO emissions are typically associated with combustion efficiency where lower $\mathrm{CO}$ emissions imply higher combustion efficiency. Figure 4.6 is a plot of the $\mathrm{CO}$ emissions throughout the 240 second cold-start tests. The trend in $\mathrm{CO}$ emissions correlates with the $\mathrm{CO}_{2}$ results. As $\mathrm{CO}$ emissions increased, $\mathrm{CO}_{2}$ emissions decreased. At $-20{ }^{\circ} \mathrm{F}$ the highest concentration of $\mathrm{CO}_{2}$ was measured around 50 seconds into the test which correlates with the lowest concentration of $\mathrm{CO}$. All of the temperatures and fuels had an increase in CO emissions at the beginning of the test and then decreased followed by a large hump which is where the peak value of the $\mathrm{CO}$ emissions were found. All of the averages at the test completion were between 4 and 6\% CO with the E15 having lower concentrations throughout for each set of temperatures.

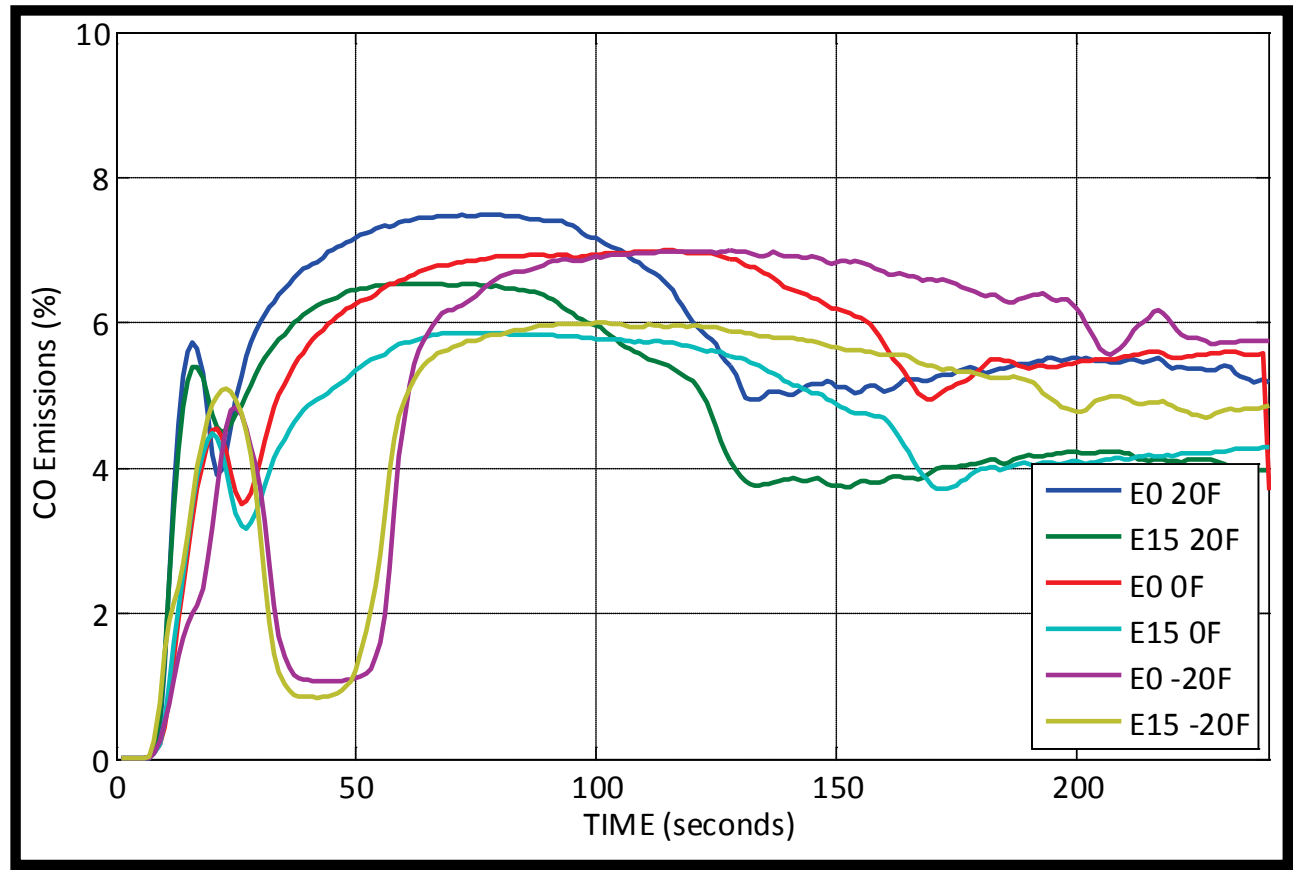

Figure 4.6: Average Yamaha cold-start CO emissions

At sub-ambient temperatures, fuel evaporation is reduced which requires additional fuel delivery to ensure a combustible mixture is formed inside the cylinder. The excess fuel that does not evaporate and burn in the cylinder is exhausted to the atmosphere. This explains the high level of THC emissions in the beginning of the cold- 
start tests as shown in Figure 4.7: All of the tests have a maximum value of THC right away and then slowly reduce over time, reaching a steady-state value between 5000 and $7500 \mathrm{ppmC} 1$. The E15 fuel interestingly had lower THC emissions for all of the averages with E0 $-20{ }^{\circ} \mathrm{F}$ having the largest value that actually exceeded the FID analyzer measurement range of $46000 \mathrm{ppmC} 1$.

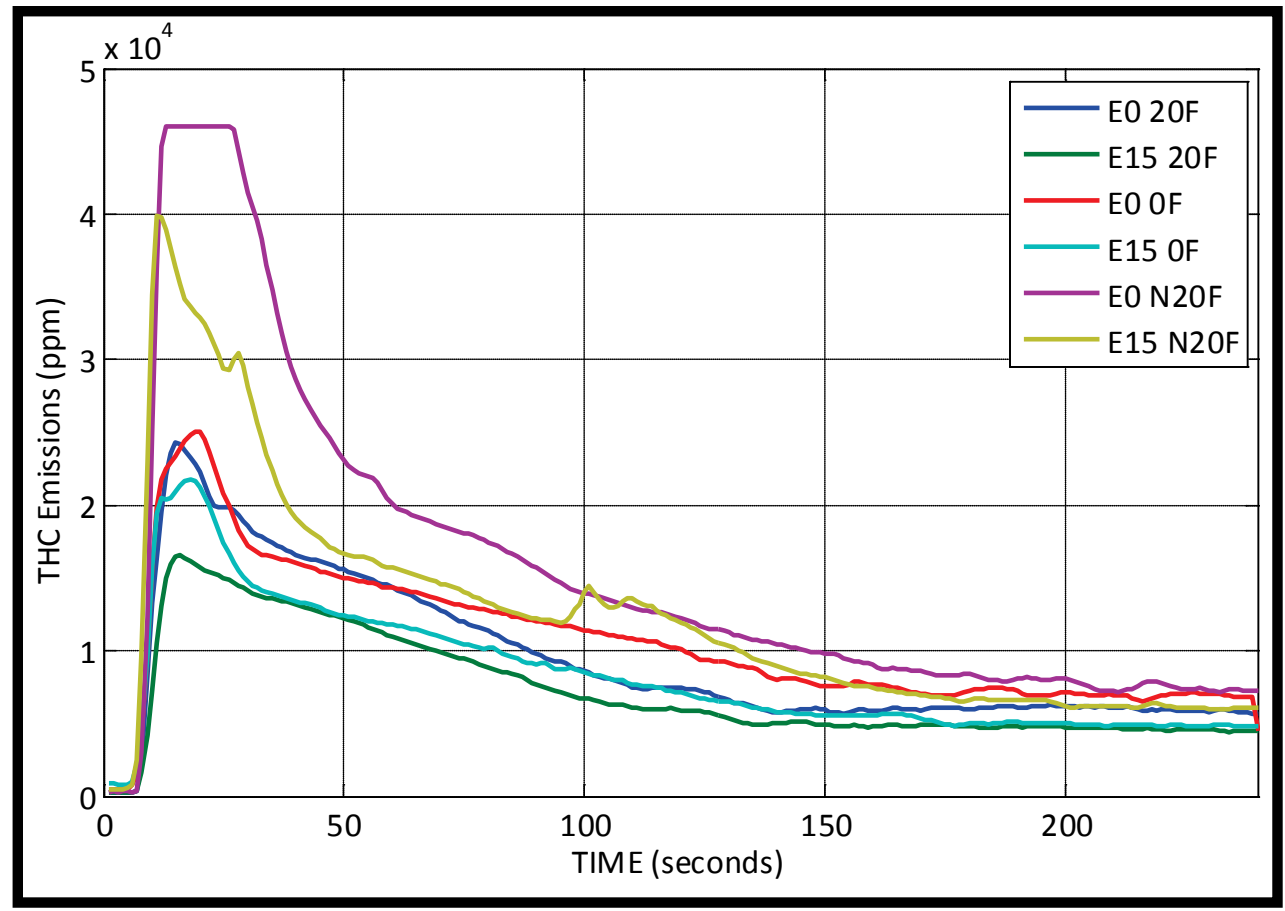

\section{Figure 4.7: Average Yamaha cold-start THC emissions}

Shown in Figure 4.8 and Figure 4.9 are the $\mathrm{O}_{2}$ concentration and air-to-fuel ratios for the Yamaha cold-start tests. The first 30 seconds of each of these plots display incorrect data because the emissions sample probe was located at the end of the exhaust outlet which lead to a significant amount of fresh air dilution. The $\mathrm{O}_{2}$ concentration and air-to-fuel ratio plots all have the same trends as they are very closely related. After the first 30 seconds of the test, the $\mathrm{O}_{2}$ content dropped to approximately $0.5 \%$ and then increased to about $0.7 \%$ except for $\mathrm{E} 020^{\circ} \mathrm{F}$ which was a bit higher. Air-to-fuel ratios had the same trend with all tests ending up at values between 11 and 12 . 


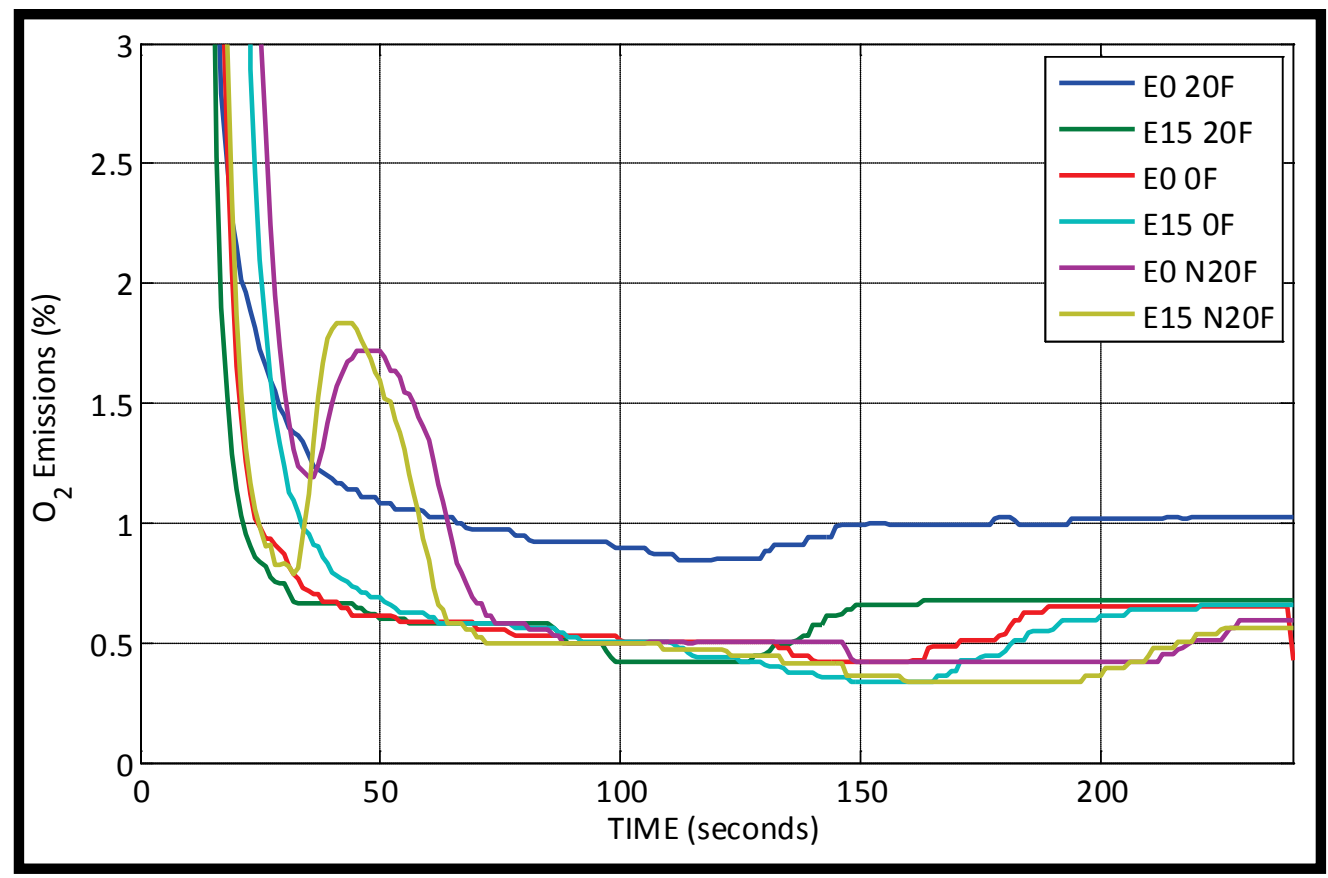

Figure 4.8: Average Yamaha cold-start $\mathrm{O}_{2}$ emissions

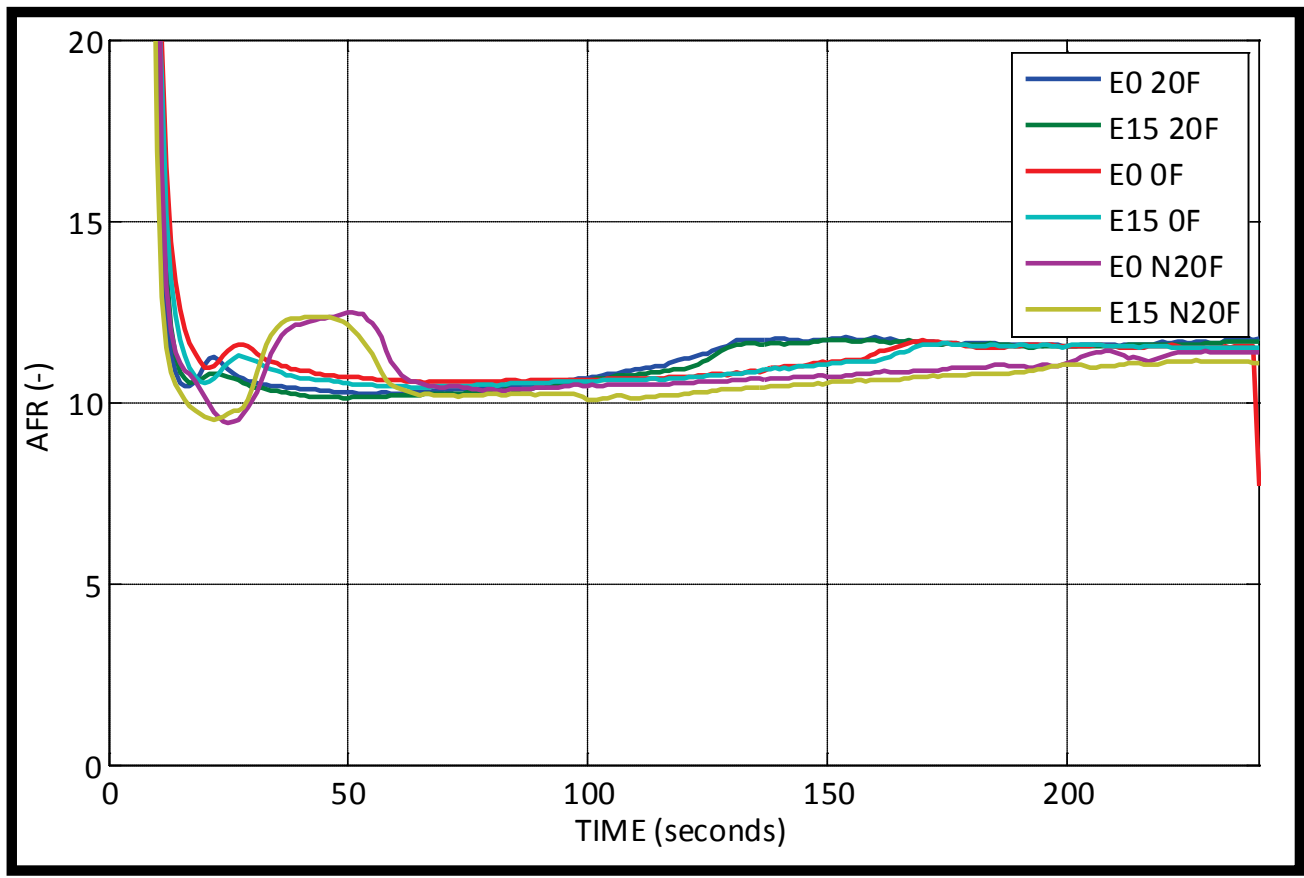

Figure 4.9: Average Yamaha cold-start air-to-fuel ratios 


\subsubsection{Yamaha Engine Data}

Table 4.2 displays the engine speeds, coolant temperatures and the MAG exhaust gas temperatures for the Yamaha. The average engine speed for each temperature was very close to each other with less than $1 \%$ difference but the average exhaust gas temperature did vary between E0 and E15 with the E15 having approximately 10 to 15 ${ }^{\circ} \mathrm{C}$ higher temperatures. Figure 4.10 displays the percent change of the engine speed and EGT at the three temperatures. The percent change decreased as the temperature decreased.

Table 4.2:

Average engine data of Yamaha

\begin{tabular}{|c|c|c|c|}
\hline & $\begin{array}{l}\text { Engine Speed } \\
\text { (RPM) }\end{array}$ & $\begin{array}{c}\text { Coolant } \\
\text { Temperature } \\
\left({ }^{\circ} \mathrm{C}\right)\end{array}$ & $\begin{array}{c}\text { Middle EGT } \\
\left({ }^{\circ} \mathrm{C}\right)\end{array}$ \\
\hline E0 $20^{\circ} \mathrm{F}$ & 2119.30 & 21.60 & 614.29 \\
\hline E15 $20^{\circ} \mathrm{F}$ & 2133.91 & 21.69 & 625.52 \\
\hline $20^{\circ} \mathbf{F}$ difference & $0.7 \%$ & $0.09{ }^{\circ} \mathrm{C}$ & $1.8 \%$ \\
\hline $\operatorname{EO~} 0^{\circ} \mathbf{F}$ & 2241.71 & 12.97 & 621.31 \\
\hline $\mathrm{E} 150^{\circ} \mathrm{F}$ & 2253.84 & 12.52 & 630.45 \\
\hline $\mathbf{0}^{\circ} \mathbf{F}$ difference & $0.5 \%$ & $-0.45^{\circ} \mathrm{C}$ & $1.5 \%$ \\
\hline E0 N20 ${ }^{\circ} \mathrm{F}$ & 2297.55 & 1.89 & 628.21 \\
\hline E15 N20 ${ }^{\circ} \mathrm{F}$ & 2296.80 & 3.20 & 636.30 \\
\hline$-20^{\circ} \mathrm{F}$ difference & $0.1 \%$ & $1.31{ }^{\circ} \mathrm{C}$ & $1.3 \%$ \\
\hline
\end{tabular}




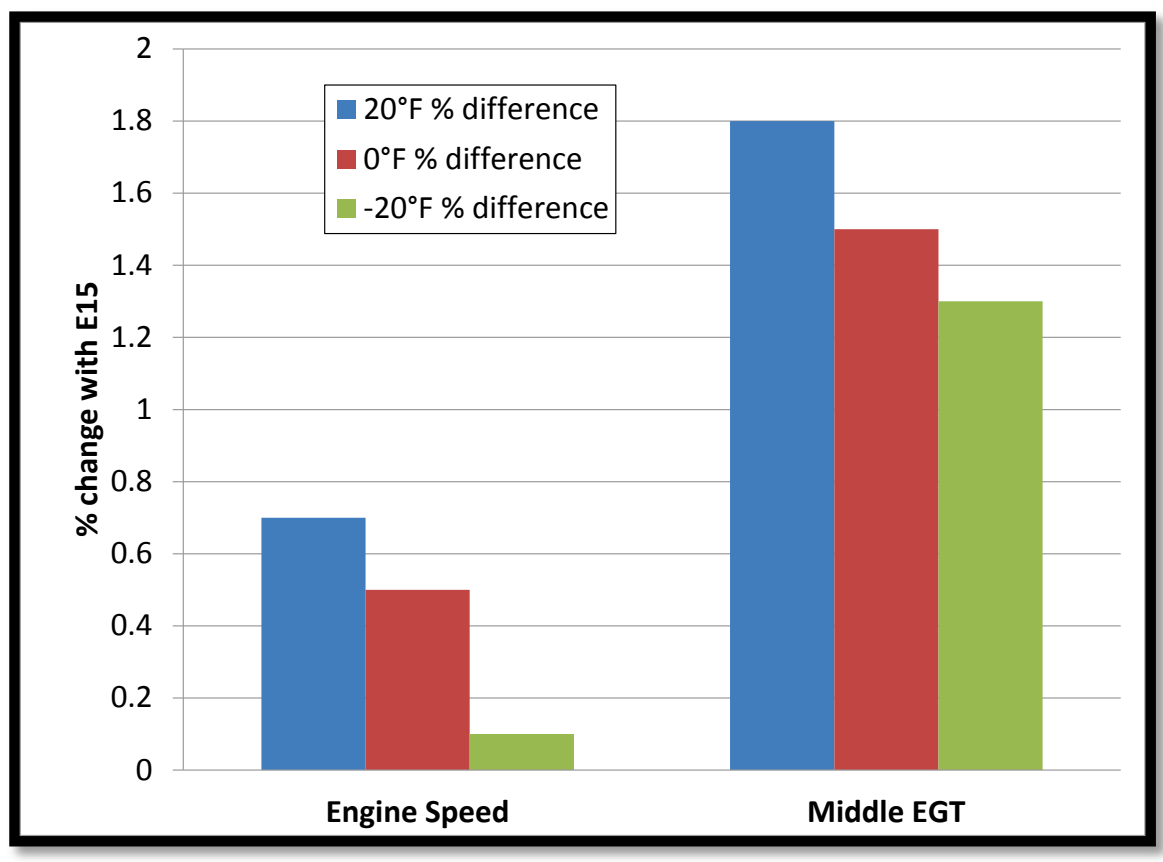

Figure 4.10: Percent change of Yamaha engine parameters when fuel changed to E15

To confirm that the tests were performed at approximately the same temperature for each fuel, the test cell temperature was recorded throughout the tests, averaged, and then plotted as shown in Figure 4.11. As can be observed, all of the tests did not have the exact same temperature but were within $4{ }^{\circ} \mathrm{F}$ of each other. The average values over the length of the tests can also be seen in Table 4.2. It is also clear that the test cell was capable of maintaining the temperature it was set to with almost no increase in temperature throughout the tests. 


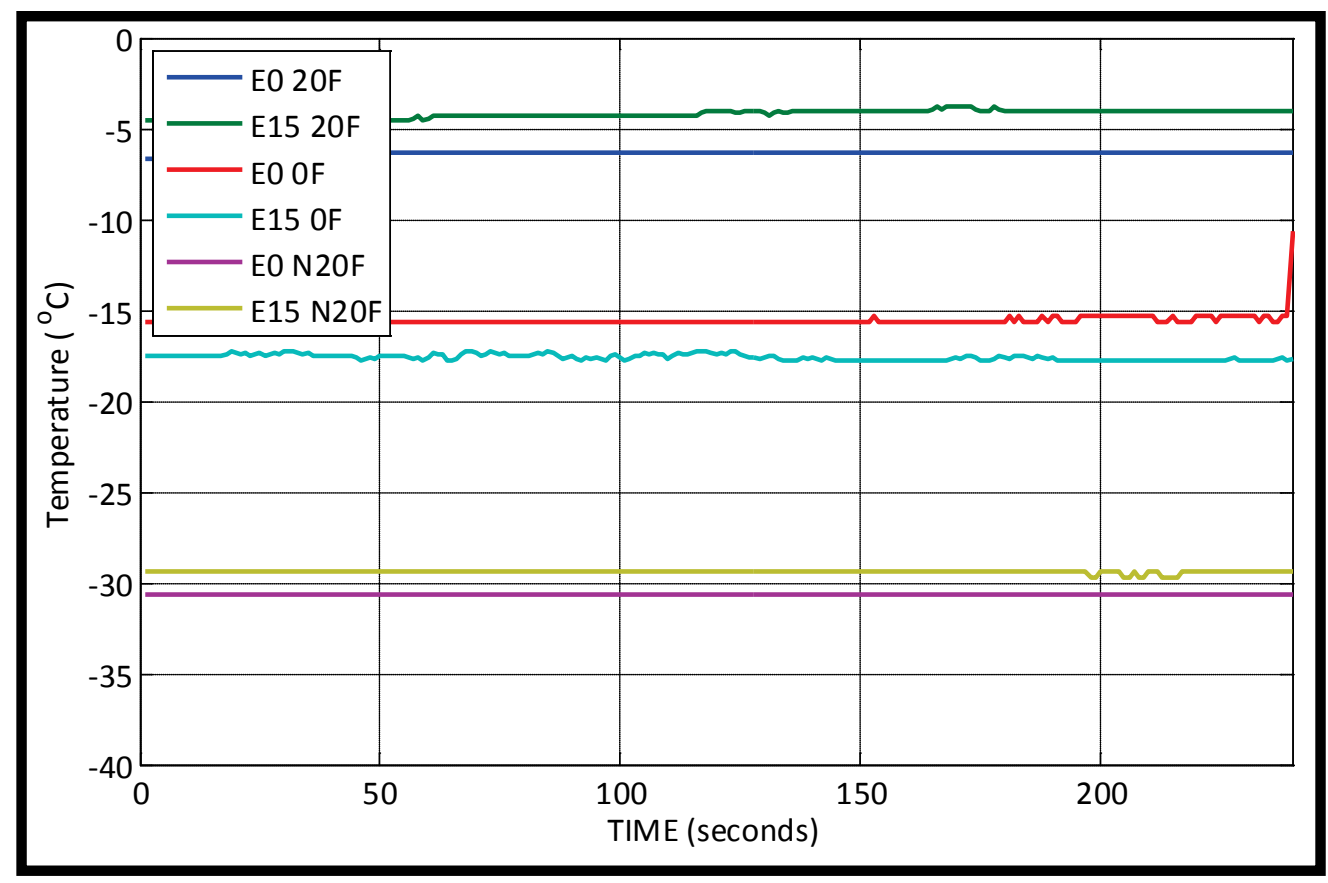

Figure 4.11: Average Yamaha cold-start test cell temperatures

Figure 4.12 shows the average engine speed for the Yamaha. As the ambient temperature decreased, the time required for the engine to idle down increased and is clearly shown in the figure. The engine idled down at about 130 seconds with an ambient temperature of $20^{\circ} \mathrm{F}$ and at $-20^{\circ} \mathrm{F}$ it idled down after approximately 210 seconds. This idle-down time correlates with the emissions trends previously discussed. When the engine speed decreased the concentrations of the measured emissions also decreased. The most interesting data is the $-20^{\circ} \mathrm{F}$ data in which the snowmobile initially fired and then after about 20 seconds it appeared like the engine was idling down and then increased the idle speed again. This calibration trend was not as noticeable in the other two temperatures, with only having slight dips in RPM before increasing idle speed. This large dip for the $-20^{\circ} \mathrm{F}$ tests also showed up in the $\mathrm{CO}_{2}, \mathrm{CO}$, and $\mathrm{O}_{2}$ concentration as having an increase or decrease in the plot at the same time. 


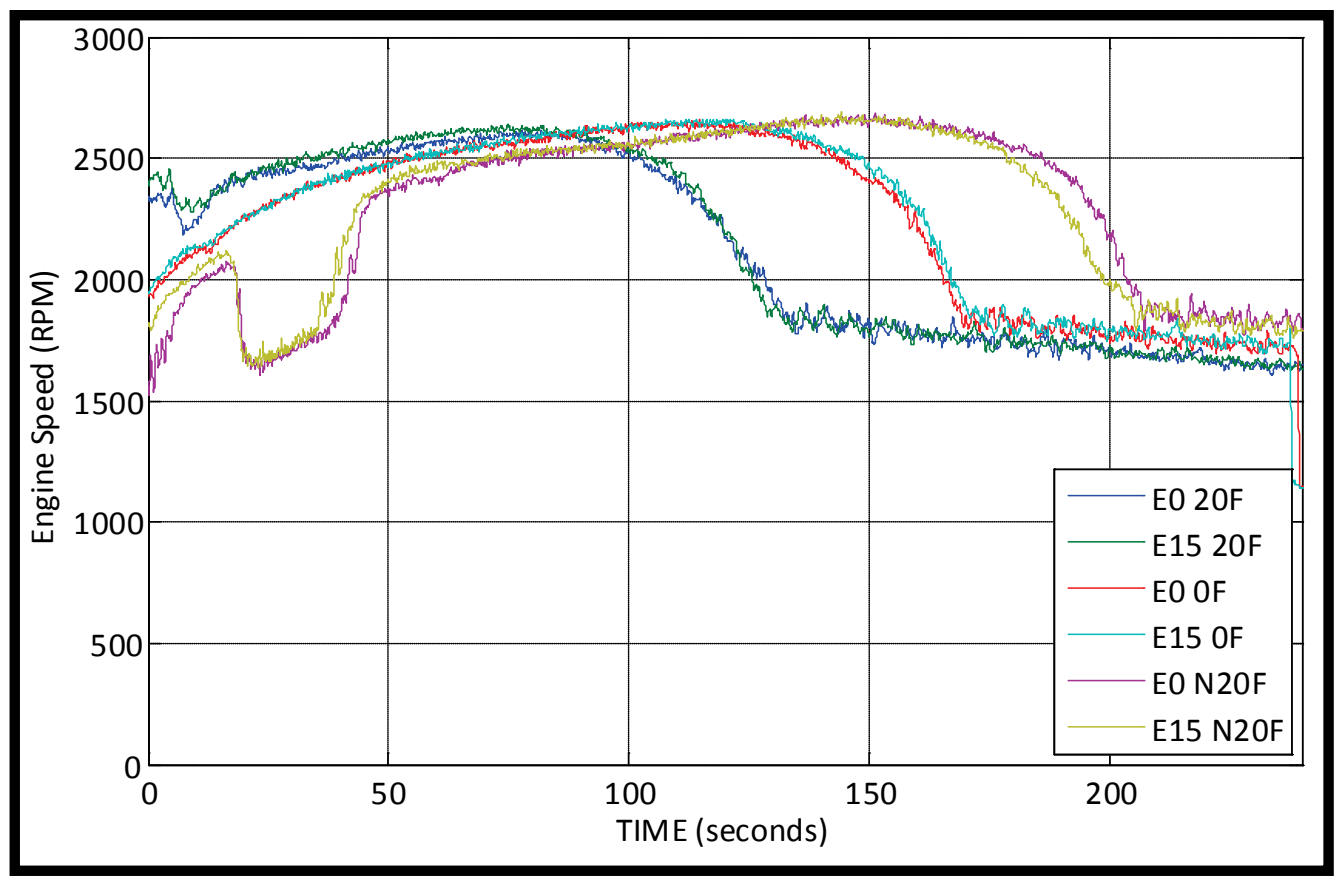

Figure 4.12: Average Yamaha cold-start engine speeds

The engine coolant temperatures are plotted in Figure 4.13 and show that all of the coolant temperatures started at the correct cold-soak temperature. No difference between the fuels was noticed.

Figure 4.14 is an example of the exhaust gas temperature from the Yamaha during the cold start tests. The exhaust gas temperature increased as the ambient temperature decreased and it was also apparent that the temperature increased with the addition of ethanol. The highest temperature of approximately $760^{\circ} \mathrm{C}$ was achieved with E15 at $20^{\circ} \mathrm{F}$. The addition of ethanol leaned out the calibration, and the temperature rose as a result of the leaner mixture. Additional data for the Yamaha is included in Appendix A.2 through Appendix A.8. 


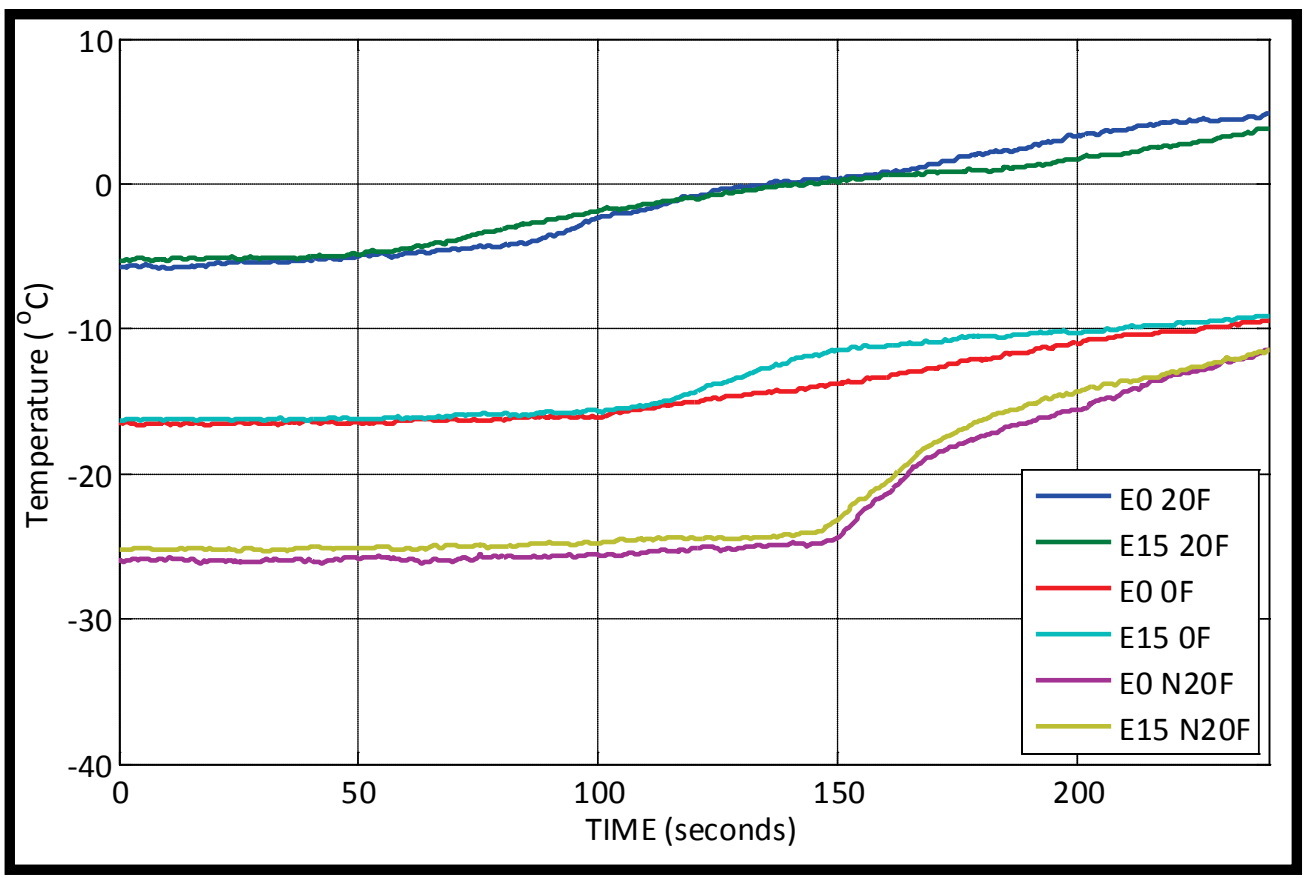

Figure 4.13: Average Yamaha cold-start engine coolant hot temperatures

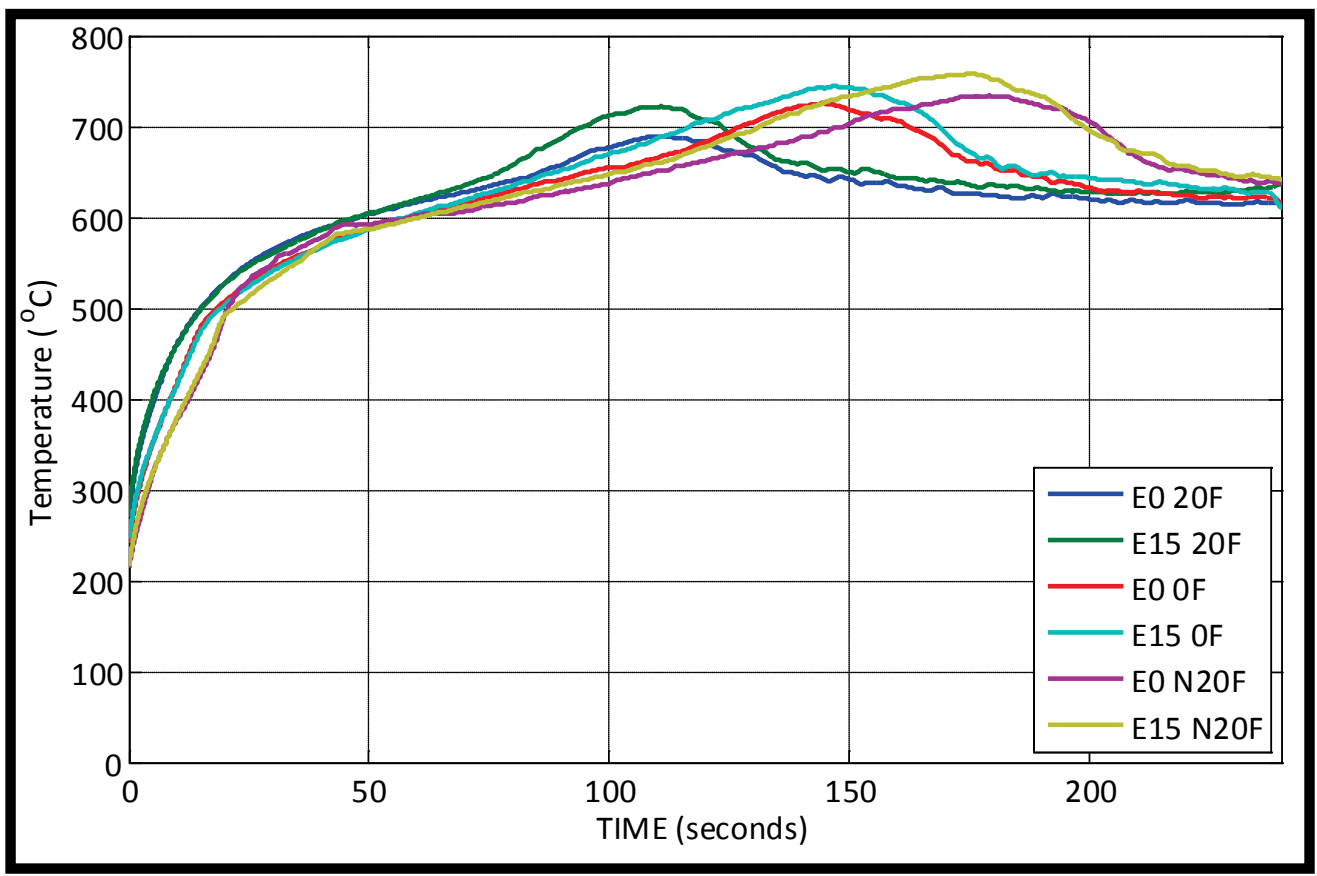

Figure 4.14: Average Yamaha cold-start center exhaust gas temperatures 


\subsection{Ski-doo MX Z TNT 600 H.O. E-TEC}

The Ski-doo had a very sophisticated engine control unit (ECU) and therefore, the cold-start tests were fairly consistent. A total of 43 tests were taken to complete all of the fuels and temperature combinations. The Ski-doo two-stroke engine had no compensation for the addition of ethanol to the fuel. Figure 4.15 displays the percent difference in emissions from the Ski-doo when the fuel was changed to E15.

Table 4.3 shows the average results from the entire duration of the cold-start tests. The $\mathrm{CO}_{2}$ levels decreased approximately $7 \%$ as ethanol was added except for the $-20^{\circ} \mathrm{F}$ in which no change was observed. The CO averages decreased approximately $17 \%$ and $5 \%$ for $0{ }^{\circ} \mathrm{F}$ and $-20^{\circ} \mathrm{F}$ respectively and increased approximately $7 \%$ for $20^{\circ} \mathrm{F}$. The THC and $\mathrm{O}_{2}$ concentration changes were around $5 \%$ for each set of temperatures with little variation and no clear pattern observed. The starting data located in the last column in the table shows that the engine started easily with the changing temperatures with only -20 ${ }^{\circ} \mathrm{F}$ requiring more than one pull. There was also no deviation with the number of pulls to start with changing the fuel. Plots further explaining these trends are included in this section. Figure 4.16 shows the number of pulls to start the snowmobile which was the same for both fuels.

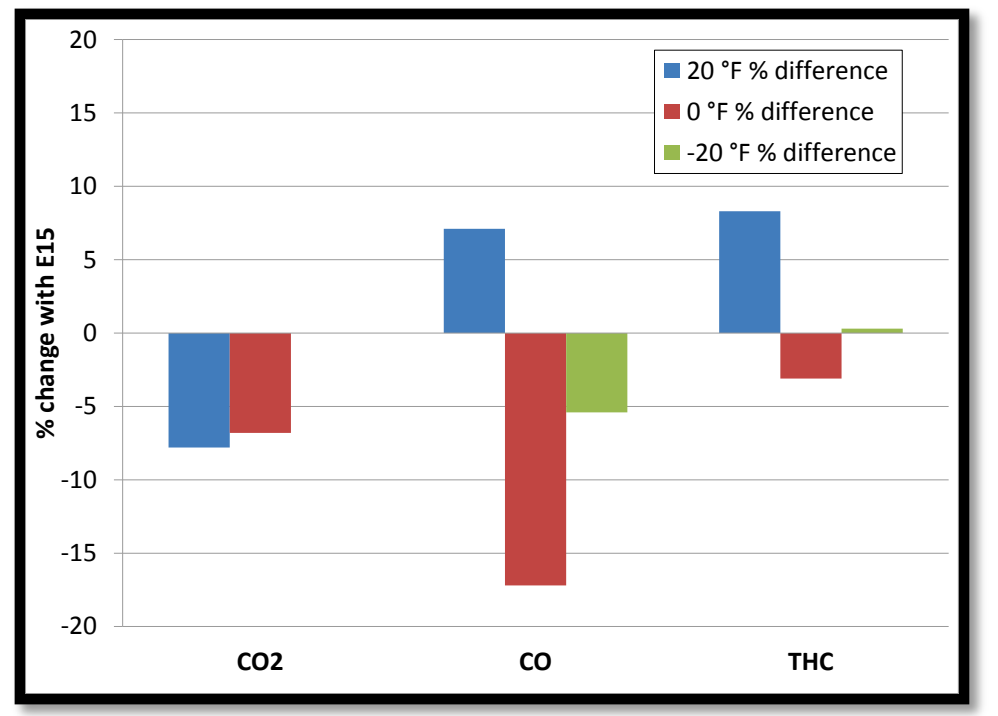

Figure 4.15: Percent change of Ski-doo emissions when fuel changed to E15 
Table 4.3:

Ski-doo average results of emissions and starting data

\begin{tabular}{|c|c|c|c|c|c|}
\hline & $\begin{array}{l}\mathrm{CO2} \\
(\%)\end{array}$ & $\begin{array}{l}\text { CO } \\
(\%)\end{array}$ & $\begin{array}{c}\text { THC } \\
(\mathbf{p p m})\end{array}$ & $\begin{array}{c}\text { O2 } \\
(\%)\end{array}$ & $\begin{array}{c}\text { Number of } \\
\text { pulls to } \\
\text { start }\end{array}$ \\
\hline E0 20 & 3.95 & 0.42 & 10838.09 & 14.73 & 1 \\
\hline E15 20 & 3.64 & 0.45 & 11741.72 & 15.33 & 1 \\
\hline $\begin{array}{c}20^{\circ} \mathrm{F} \\
\text { difference }\end{array}$ & $-7.8 \%$ & $7.1 \%$ & $8.3 \%$ & $4.1 \%$ & 0 pulls \\
\hline E0 0 & 4.00 & 0.58 & 12423.47 & 14.65 & 1 \\
\hline E150 & 3.73 & 0.48 & 12044.09 & 15.52 & 1 \\
\hline $\begin{array}{c}\mathbf{0}^{\circ} \mathbf{F} \\
\text { difference }\end{array}$ & $-6.8 \%$ & $-17.2 \%$ & $-3.1 \%$ & $5.9 \%$ & 0 pulls \\
\hline E0 N20 & 3.73 & 0.37 & 11281.31 & 15.47 & 2.33 \\
\hline E15 N20 & 3.73 & 0.35 & 11314.54 & 15.18 & 2.33 \\
\hline $\begin{array}{c}-20^{\circ} \mathrm{F} \\
\text { difference }\end{array}$ & $0.0 \%$ & $-5.4 \%$ & $0.3 \%$ & $-1.9 \%$ & 0 pulls \\
\hline
\end{tabular}




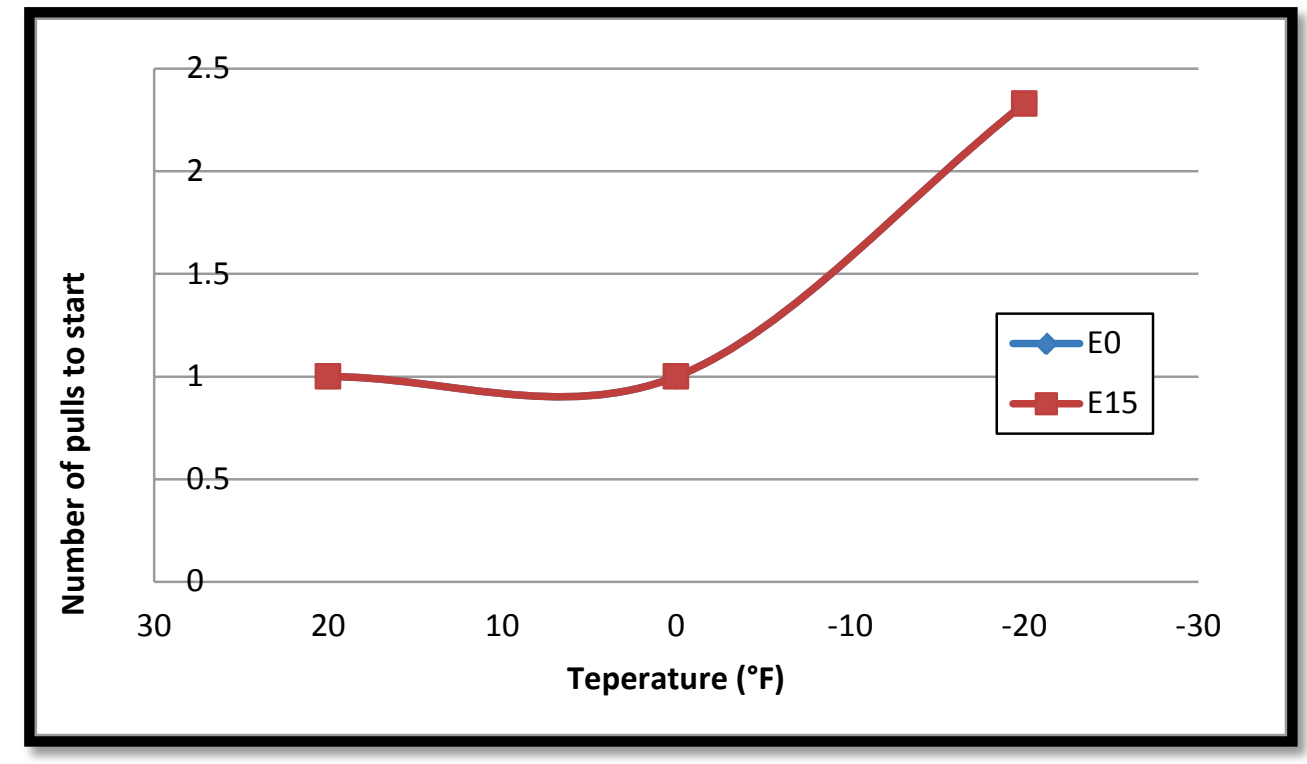

Figure 4.16: Average Ski-doo cold-start number of pulls required to start the engine

\subsubsection{Ski-doo Emissions}

The emissions for the Skidoo were similar and changes did not appear to depend on ambient temperature or fuel supplied to the snowmobile. Figure 4.17 below is a plot of the $\mathrm{CO}_{2}$ emissions during the first 180 seconds of each test. All of the $\mathrm{CO}_{2}$ traces increased to around $4 \%$ for $20^{\circ} \mathrm{F}$ and $0{ }^{\circ} \mathrm{F}$ with E0 having a slightly higher concentration. E0 also had a higher concentration at $-20^{\circ} \mathrm{F}$ but both fuels had an increased peak value to around $5.8 \%$ early in the test. All of the averages ended up leveling out to between 3.5 and $4.2 \% \mathrm{CO}_{2}$ at the end of the test with the E0 fuel remaining slightly higher. 


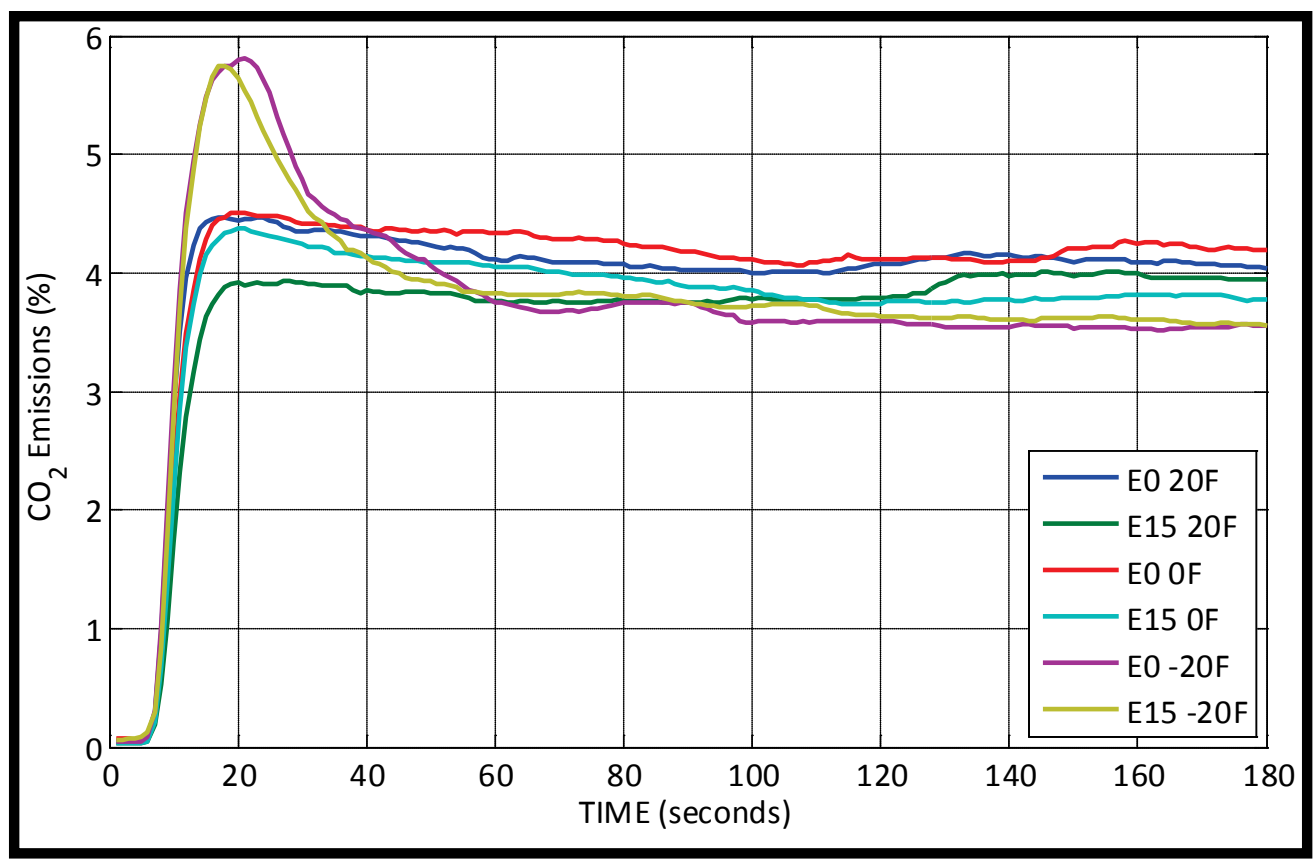

Figure 4.17: Average Ski-doo cold-start $\mathrm{CO}_{2}$ emissions

In Figure 4.18, $\mathrm{CO}$ emissions are plotted for the various cold-start tests. At $20^{\circ} \mathrm{F}$, no noticeable differences were observed between E0 and E15. They both increased and decreased at approximately the same rate throughout the test. However at $0{ }^{\circ} \mathrm{F}$ and -20 ${ }^{\circ} \mathrm{F}$, there was a significant difference with the E0 fuel having higher concentrations of $\mathrm{CO}$ in the beginning of the tests. At $0^{\circ} \mathrm{F}$ the E0 fuel continued to have higher concentrations while at $-20{ }^{\circ} \mathrm{F}$, after about a minute, there was no noticeable difference in the concentrations between fuels. The large spike in Figure 4.18 along with the large spike in the $\mathrm{CO}_{2}$ plot shows that excess fuel was in the engine for the coldest temperature. This could have been a result of the additional pulls required to start the engine when compared to the other two temperatures. The majority of the averages at the end of the test were between 0.25 and $0.5 \% \mathrm{CO}$ with $-20{ }^{\circ} \mathrm{F}$ tests having lower concentrations. E0 at $0{ }^{\circ} \mathrm{F}$ had a higher concentration of about $0.6 \%$. 


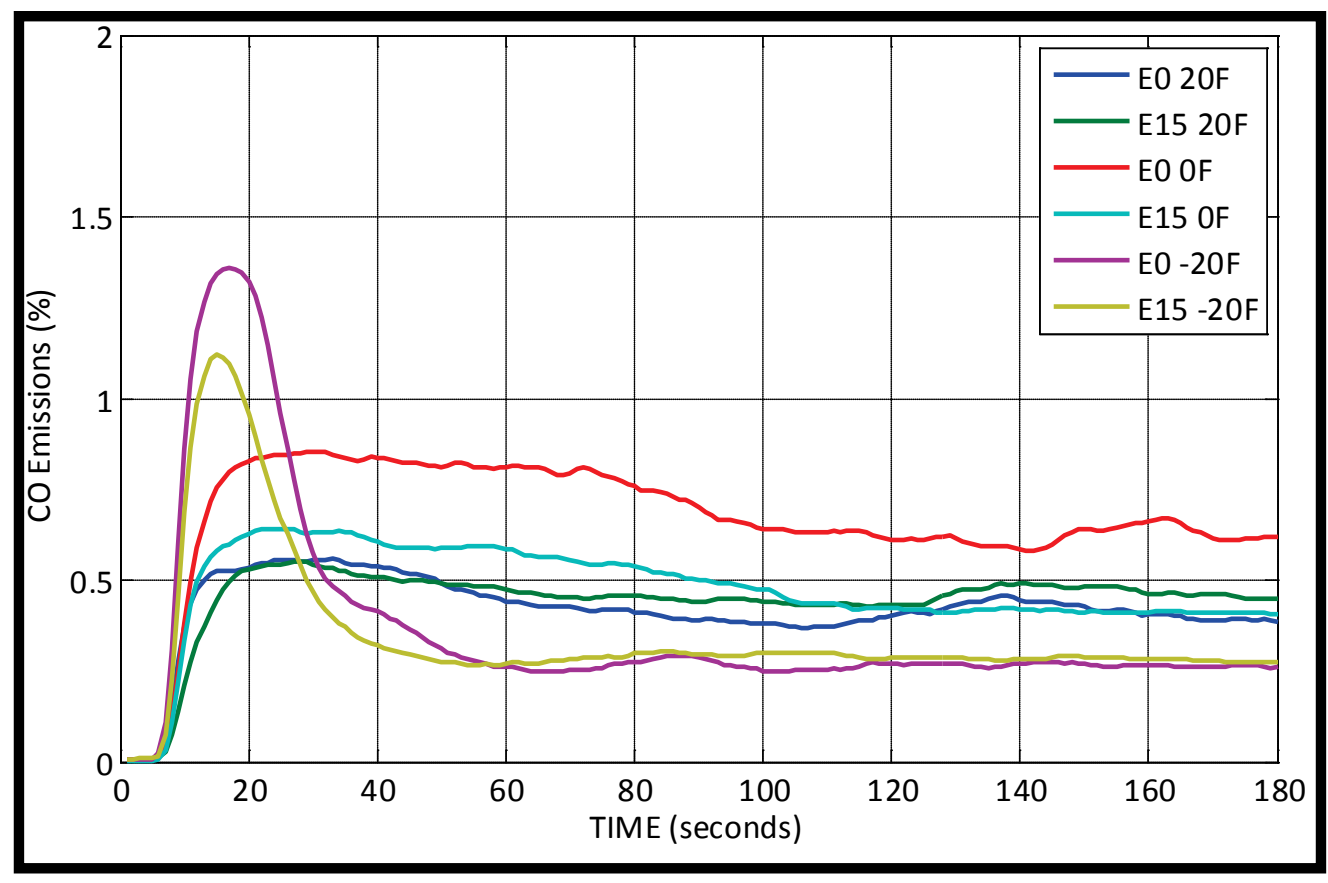

Figure 4.18: Average Ski-doo cold-start CO emissions

For a conventional two-stroke engine, THC emissions at idle are typically quite high due to the poor expansion chamber tuning and lower temperatures to aid oxidation. High HC emissions were not observed for this Ski-doo, as shown in Figure 4.19. The relatively low $\mathrm{HC}$ emissions were possibly due to the direct injection of the fuel into the cylinder which significantly reduced the short-circuited fuel at idle. In Figure 4.19, the hydrocarbons rise to a level between 12,000 and 15,000 ppmC1 for all tests. The only average that had a higher value was the E0 at $0{ }^{\circ} \mathrm{F}$. During the individual tests, there were definite differences from one test to another with seemingly no difference in the setup or process. It is believed the ECU was compensating for increased load on the engine due to the drive belt location in the clutches. The calibration could have adjusted fuel delivery to maintain an idle speed of $1200 \mathrm{rpm}$. For the other two temperatures, the E0 fuel had a slightly lower concentration of THC than the E15 fuel. It was unexpected to have this small of variation in hydrocarbons with the different fuels and temperatures. 


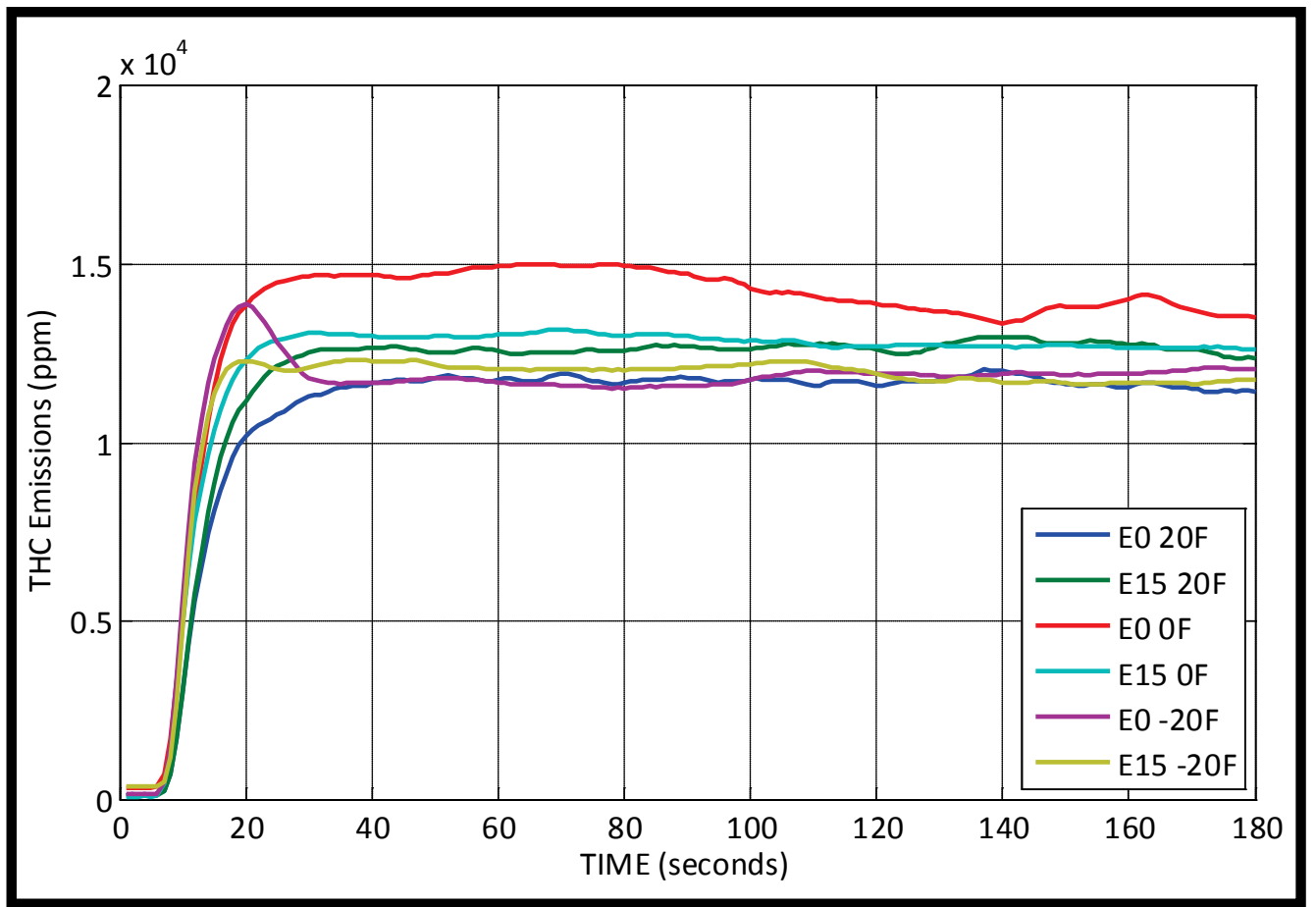

Figure 4.19: Average Ski-doo cold-start THC emissions

At idle for a two-stroke, it is difficult to get all of the fuel and air to mix, therefore, large amounts of fuel and air will pass through the engine and out the exhaust. Figure 4.20 shows that there was anywhere from 12 to $16 \% \mathrm{O}_{2}$ concentration in the exhaust. This excess $\mathrm{O}_{2}$ also correlates to Figure 4.21 which shows the lambda value throughout the tests. At $0{ }^{\circ} \mathrm{F}$ and $20^{\circ} \mathrm{F}$, E15 had the higher $\mathrm{O}_{2}$ concentration and lambda value until the end of the test where the values get closer. At $-20^{\circ} \mathrm{F}$, the two fuels had very similar values throughout the test. The air to fuel ratios of the averages never dropped below a value of 25 which is why the instrumented wide-band lambda sensor was always maxed out at 22 for AFR and the data from the sensor was not useful. 


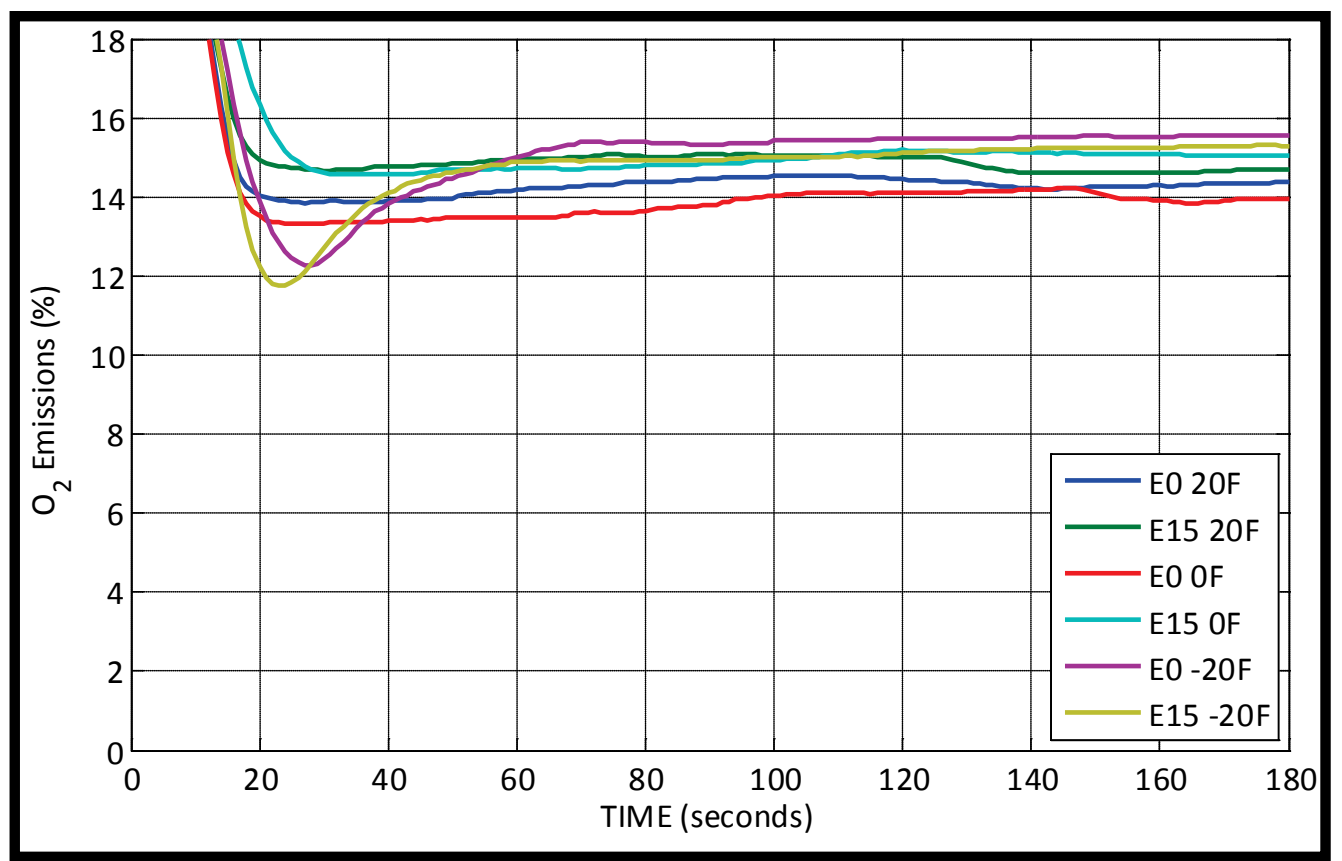

Figure 4.20: Average Ski-doo cold-start $\mathrm{O}_{2}$ concentrations

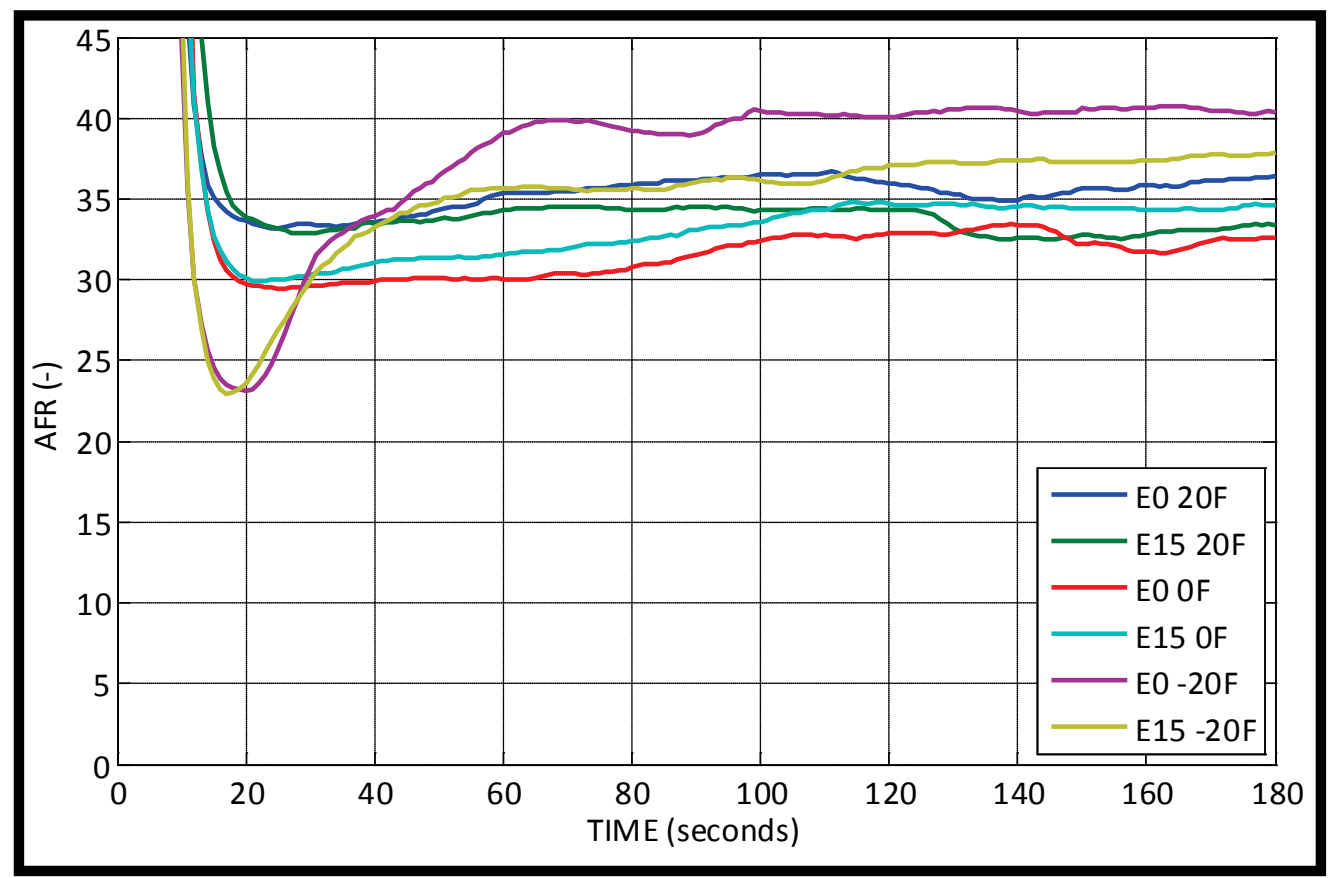

Figure 4.21: Average Ski-doo cold-start air to fuel ratios 


\subsubsection{Ski-doo Engine Data}

Table 4.4 displays the average engine speeds, coolant temperatures and the MAG exhaust gas temperatures. Figure 4.22 displays the percent changes of engine speed and EGT when the fuel was changed to E15. The average engine speed for each temperature was relatively close to each other with increasing speeds as temperature decreased. The average exhaust gas temperature did vary slightly from E0 to E15 with the E15 having approximately 3 to $12 \%$ decreases. To show that the tests were performed at approximately the same temperatures, the average test cell temperatures are shown in Figure 4.23.

Table 4.4:

Average engine data of Ski-doo

\begin{tabular}{|c|c|c|c|c|}
\hline & $\begin{array}{l}\text { Engine } \\
\text { Speed } \\
\text { (RPM) }\end{array}$ & $\begin{array}{c}\text { Coolant } \\
\text { Temp }\left({ }^{\circ} \mathrm{C}\right)\end{array}$ & $\begin{array}{c}\text { MAG Head } \\
\text { Temp }\left({ }^{\circ} \mathrm{C}\right)\end{array}$ & $\begin{array}{c}\text { MAG EGT } \\
\left({ }^{\mathbf{0}} \mathrm{C}\right)\end{array}$ \\
\hline E0 $20^{\circ} \mathrm{F}$ & 1259 & -0.3 & 13.2 & 155.1 \\
\hline E15 $20^{\circ} \mathrm{F}$ & 1263 & 1.23 & 11.1 & 143.9 \\
\hline $\begin{array}{c}20^{\circ} \mathbf{F} \\
\text { difference }\end{array}$ & $0.3 \%$ & $1.26^{\circ} \mathrm{C}$ & $-16.2 \%$ & $-7.2 \%$ \\
\hline $\mathbf{E O ~} 0^{\circ} \mathrm{F}$ & 1278 & -6.1 & 7.8 & 168.5 \\
\hline $\mathbf{E} 150^{\circ} \mathrm{F}$ & 1297 & -8.7 & 2.3 & 147.7 \\
\hline $\begin{array}{c}\mathbf{0}^{\circ} \mathbf{F} \\
\text { difference }\end{array}$ & $1.5 \%$ & $-1.4{ }^{\circ} \mathrm{C}$ & $-70.6 \%$ & $-12.4 \%$ \\
\hline E0 $-20^{\circ} \mathrm{F}$ & 1312 & -20.7 & -7.3 & 138.5 \\
\hline $\begin{array}{c}\mathrm{E} 15-20 \\
{ }^{0} \mathrm{~F}\end{array}$ & 1296 & -20.1 & -6.4 & 134.0 \\
\hline $\begin{array}{c}-20^{\circ} \mathbf{F} \\
\text { difference }\end{array}$ & $-1.3 \%$ & $-0.6{ }^{\circ} \mathrm{C}$ & $-13.5 \%$ & $-3.2 \%$ \\
\hline
\end{tabular}




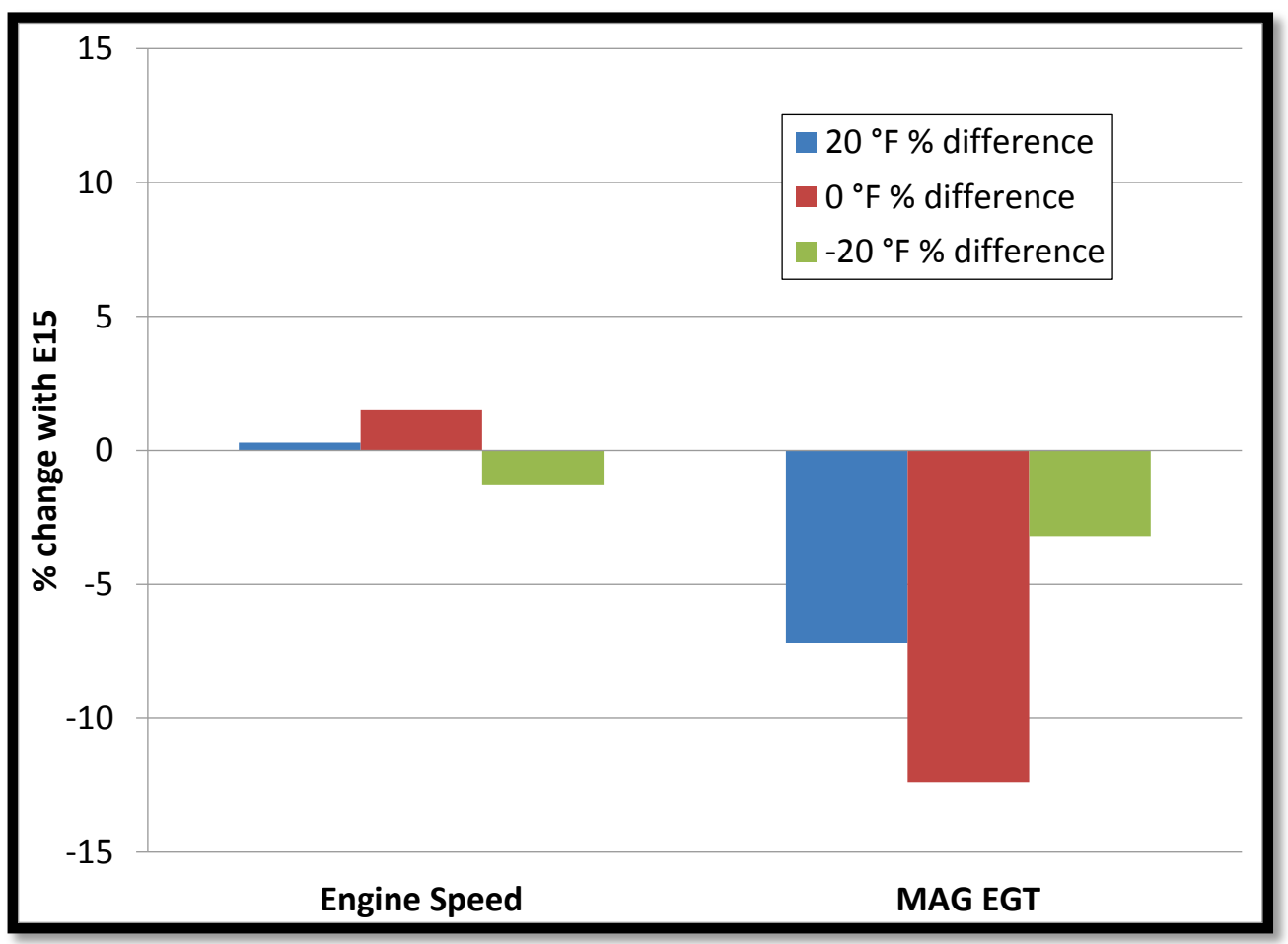

Figure 4.22: Percent change of Ski-doo engine parameters when fuel changed to E15

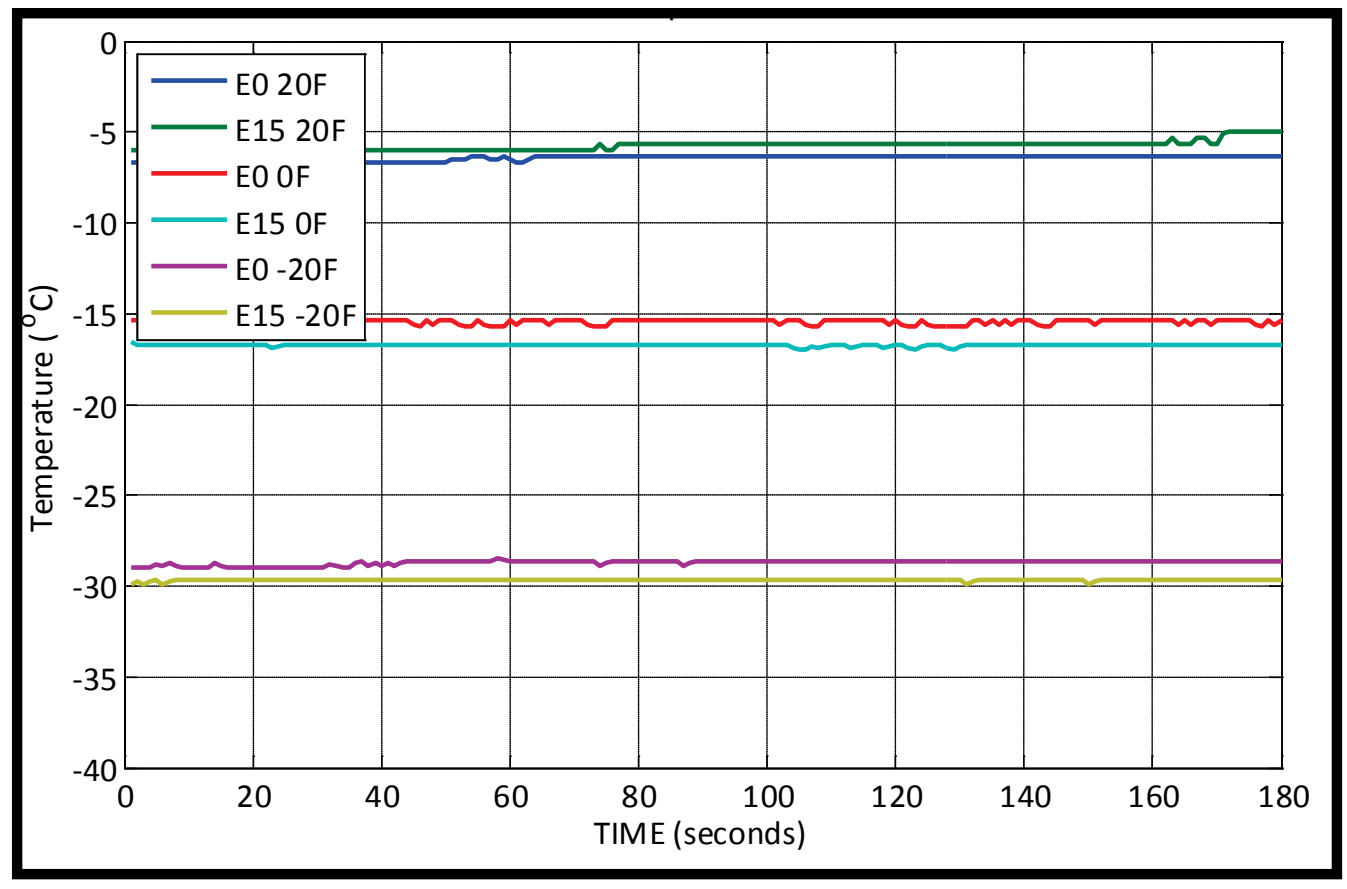

Figure 4.23: Average Ski-doo cold-start test cell temperatures 
Figure 4.24 shows the averages for the engine speed with very consistent results for both fuels at the different temperatures. For $0^{\circ} \mathrm{F}$ and $20^{\circ} \mathrm{F}$, when the engine started, the engine idled at approximately 1300 RPM. As the engine warmed up, it idled down to 1200 RPM. The idle down location varied depending on the ambient temperature. At 20 ${ }^{\circ} \mathrm{F}$ the idle down was between 100 and 120 seconds. For E0 and $0{ }^{\circ} \mathrm{F}$, the engine idled down around 130 seconds with E15 at $0{ }^{\circ} \mathrm{F}$ the engine did not idle down for the entire duration of the test (180 seconds). At $-20^{\circ} \mathrm{F}$, initially the engine idled higher between 1500 and 1600 RPM and after 40 seconds idled down to 1300 RPM. At $-20{ }^{\circ} \mathrm{F}$, the engine did not idle down to 1200 RPM which was probably due to the colder temperature. The two peaks in engine speed around 10 seconds into the $-20{ }^{\circ} \mathrm{F}$ test correlate with the increase in $\mathrm{CO}_{2}$ and $\mathrm{CO}$ emissions shown previously in Figure 4.17 and Figure 4.18. The additional pulls required to start the engine would have delivered more fuel to the cylinder, thus increasing carbon emissions as well as the early engine speed.

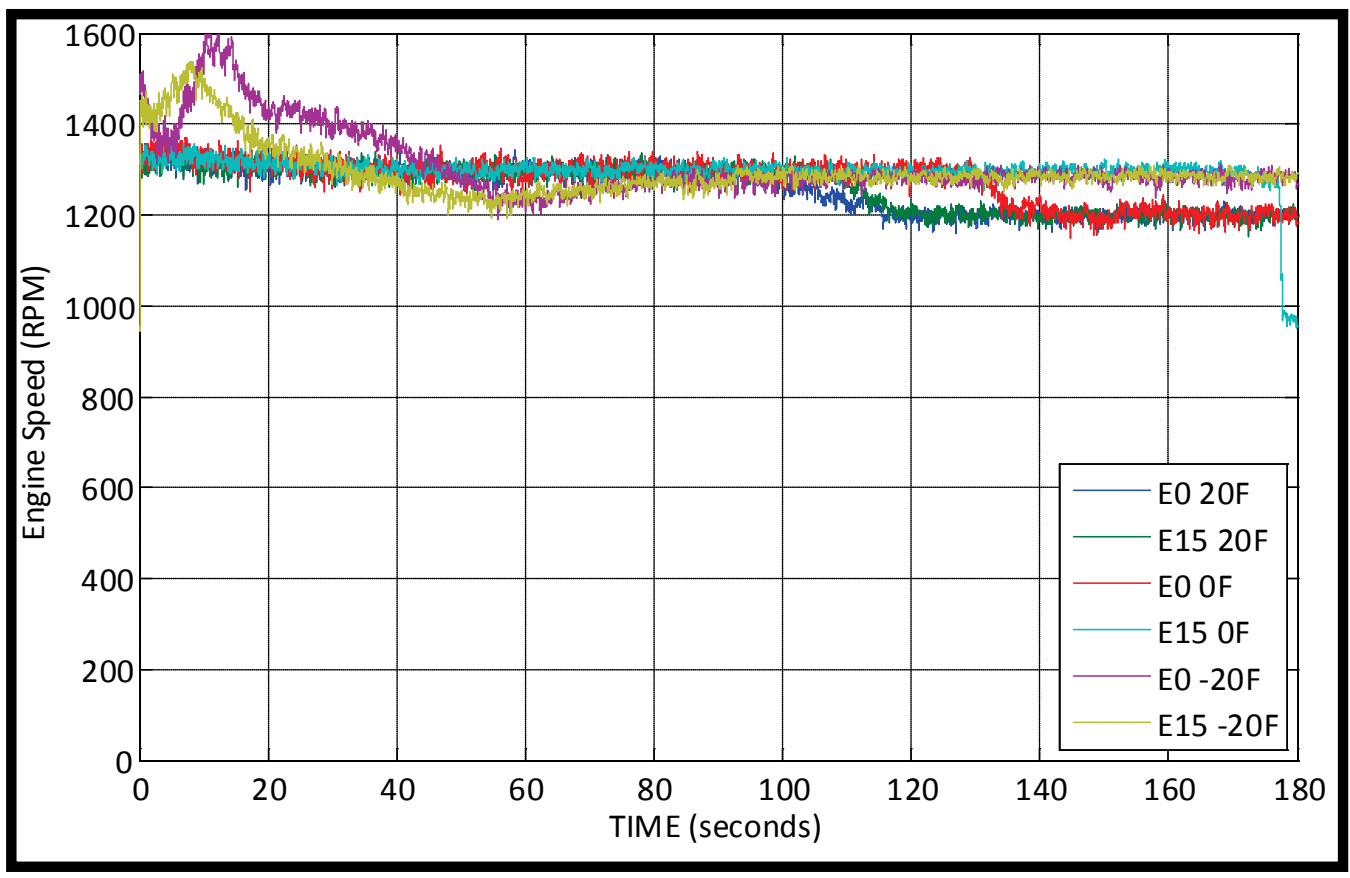

Figure 4.24: Average Ski-doo cold-start engine speeds 
Figure 4.25 shows the engine coolant temperatures for the Ski-doo during the cold start tests. This plot shows that the engine was properly soaked in the ambient environment before the start of each cold-start test. The only average that deviated was $\mathrm{E} 0$ at $0{ }^{\circ} \mathrm{F}$ average which increased at a greater rate than other tests which could be due to engine calibration.

Head temperatures provide useful information on how each cylinder is running compared to the other. It is also useful in the cold start tests to see the transient condition from cold to warmed up. The same trends observed in the engine coolant temperatures were observed in Figure 4.26 which is the MAG cylinder head temperature. All tests started at the specified cold-soaked temperature and increased as time continued at the same rate except for $\mathrm{E} 0$ at $0{ }^{\circ} \mathrm{F}$ which increased at a greater rate.

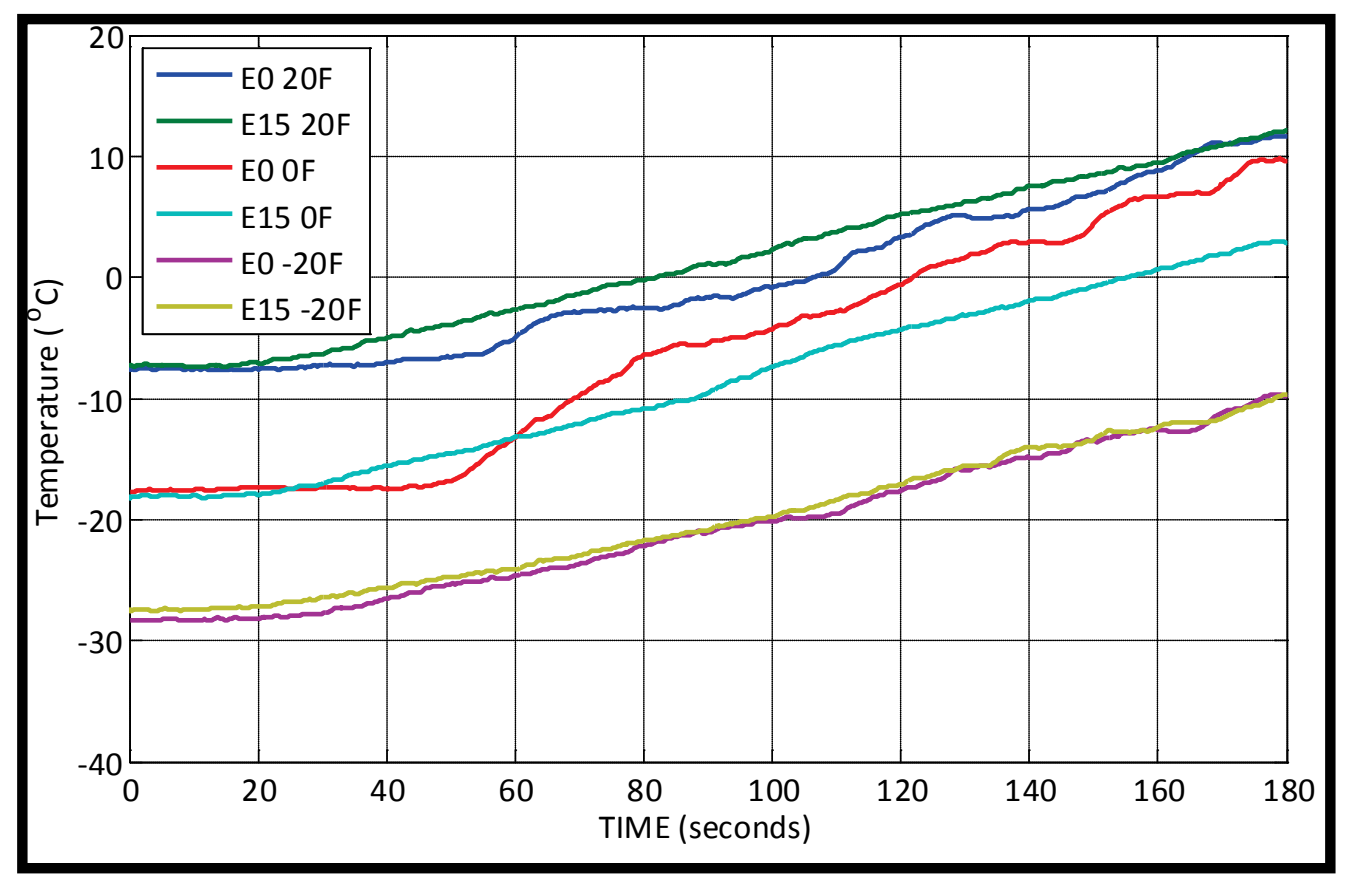

Figure 4.25: Average Ski-doo cold-start engine coolant temperatures 


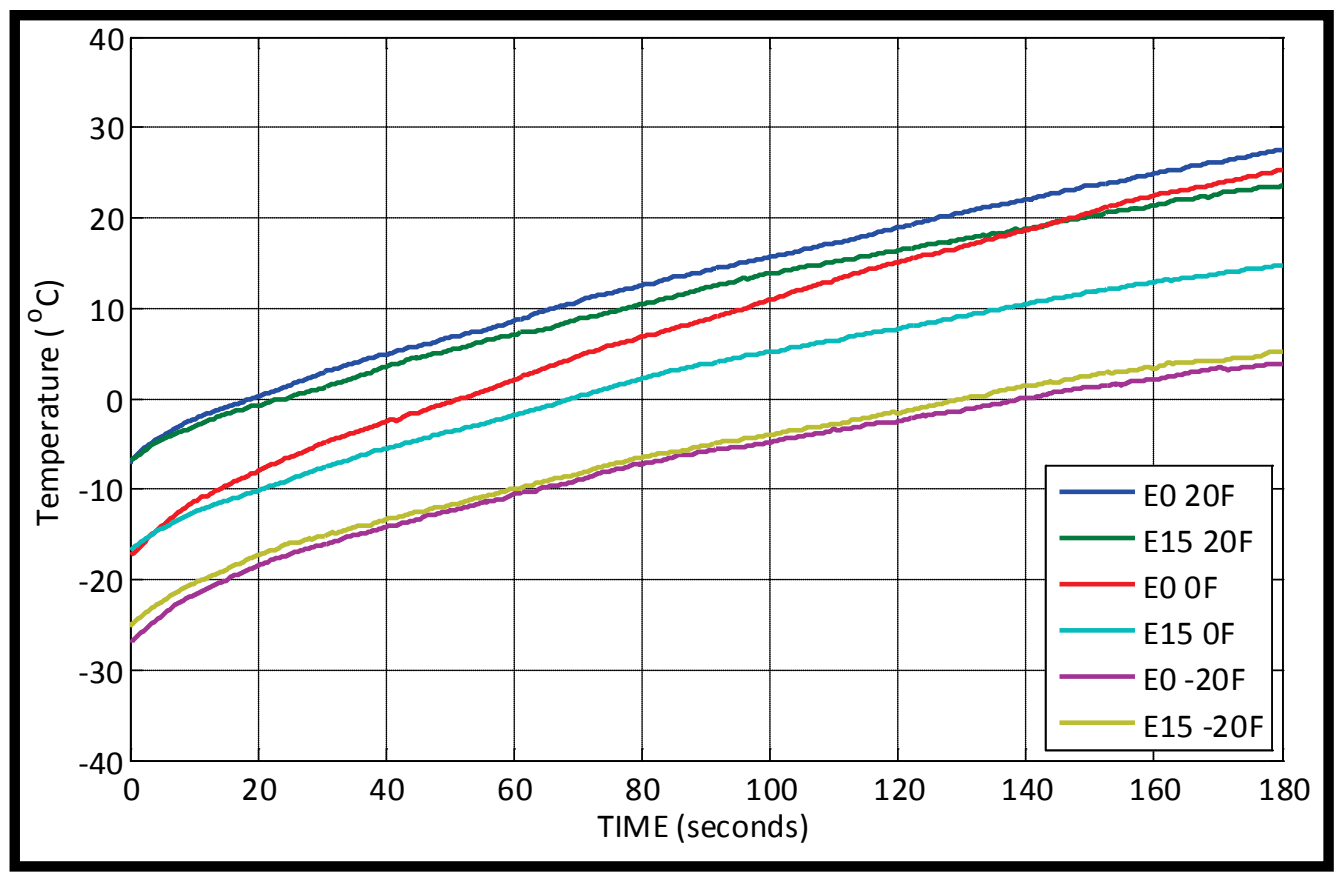

Figure 4.26: Average Ski-doo cold-start MAG head temperatures

An engine will have the hottest exhaust temperatures when operating just lean of stoichiometry (Heywood, 1988). At idle, the Ski-doo operated very lean so when the calibration moved farther away from stoichiometry (E0 to E15) could be the reason for the lower exhaust gas temperatures. Figure 4.27 shows the MAG side exhaust gas temperature averages. Initially for the $-20^{\circ} \mathrm{F}$ tests, there was a large peak which was caused by the excess fuel in the cylinder when the engine fired. At the 180 seconds, $0^{\circ} \mathrm{F}$ and $20{ }^{\circ} \mathrm{F}$ ended at the same point of about $160{ }^{\circ} \mathrm{C}$ except for the E0 at $0{ }^{\circ} \mathrm{F}$. The $-20{ }^{\circ} \mathrm{F}$ tests appear as they were still warming up at 180 seconds as they were at about $140{ }^{\circ} \mathrm{C}$. Additional plots of Ski-doo cold-start data such as ambient pressures and relative humidity are located in Appendix A.9 to Appendix A.15. 


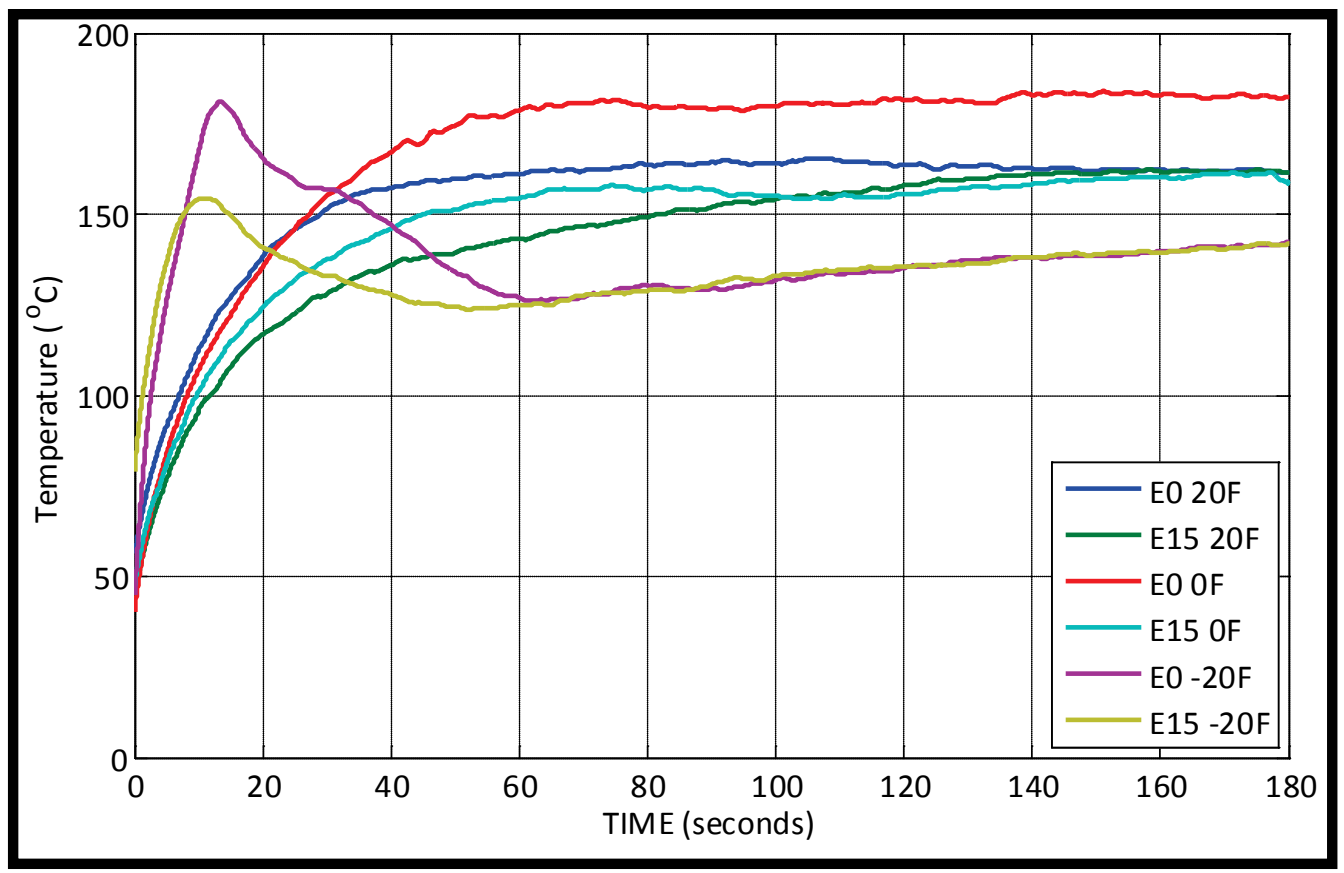

Figure 4.27: Average Ski-doo cold-start MAG exhaust gas temperatures

\subsection{Polaris 800 Rush}

The Polaris 800 snowmobile used electronic fuel injection to deliver fuel directly to the crankcase of the snowmobile. A unique feature of this snowmobile was that when different fuels were used, a resistor was changed in the wiring harness to compensate for the oxygenated fuel. When operating on E0, a $160 \mathrm{Ohm}$ resistor was used and when using $10 \%$ ethanol, a $24 \mathrm{Ohm}$ resistor was used according to the owner's manual.

Table 4.5 shows the average data for the duration of the cold start results and Figure 4.28 displays the percent change of $\mathrm{CO}_{2}$ and $\mathrm{CO} . \mathrm{CO}_{2}$ was very consistent across all temperature and both fuels tested. $\mathrm{CO}$ emissions were also very consistent for all the tests, but did show a slight reduction as the ambient temperature was reduced. The HC data exceeded the analyzer range and thus no meaningful data was able to be extracted from the results. The $\mathrm{O}_{2}$ concentration was also consistent being around $12.22 \%$ to $13.22 \%$ for all tests. For each temperature the number of pulls to start the engine was recorded and the averages show that at every temperature, it took slightly more pulls to 
start the engine using E15 fuel. A consistent trend of more pulls as the ambient temperature reduced was noted. Figure 4.29 shows the number of pulls needed to start the engine on each fuel.

Table 4.5:

Average Polaris results of emissions and starting data

\begin{tabular}{|c|c|c|c|c|c|}
\hline & $\begin{array}{c}\mathrm{CO2} \\
(\%)\end{array}$ & $\begin{array}{l}\text { CO } \\
(\%)\end{array}$ & $\begin{array}{c}\text { THC } \\
(\mathbf{p p m})\end{array}$ & $\begin{array}{c}\text { O2 } \\
(\%)\end{array}$ & $\begin{array}{c}\text { Number of } \\
\text { pulls to } \\
\text { start }\end{array}$ \\
\hline E0 $20{ }^{\circ} \mathbf{F}$ & 2.50 & 3.56 & Maxed & 12.79 & 2 \\
\hline E15 $20^{\circ} \mathrm{F}$ & 2.47 & 3.56 & Maxed & 12.42 & 2.4 \\
\hline $\begin{array}{c}20^{\circ} \mathbf{F} \\
\text { difference }\end{array}$ & $-1.2 \%$ & $0.0 \%$ & $\mathrm{~N} / \mathrm{A}$ & $-2.9 \%$ & 0.4 pulls \\
\hline $\mathbf{E 0} 0^{\circ} \mathbf{F}$ & 2.52 & 3.44 & Maxed & 12.30 & 3 \\
\hline $\mathbf{E} 150^{\circ} \mathbf{F}$ & 2.30 & 3.51 & Maxed & 13.28 & 3.75 \\
\hline $\begin{array}{c}\mathbf{0}^{\circ} \mathbf{F} \\
\text { difference }\end{array}$ & $-8.7 \%$ & $2.0 \%$ & N/A & $8.0 \%$ & 0.75 pulls \\
\hline E0 -20 ${ }^{\circ} \mathbf{F}$ & 2.53 & 3.39 & Maxed & 13.22 & 5.33 \\
\hline $\begin{array}{c}\text { E15 -20 } \\
{ }^{\circ} \mathrm{F}\end{array}$ & 2.53 & 3.32 & Maxed & 12.46 & 5.5 \\
\hline $\begin{array}{c}-20{ }^{\circ} \mathrm{F} \\
\text { difference }\end{array}$ & $0.0 \%$ & $-2.1 \%$ & N/A & $-5.7 \%$ & 0.17 pulls \\
\hline
\end{tabular}




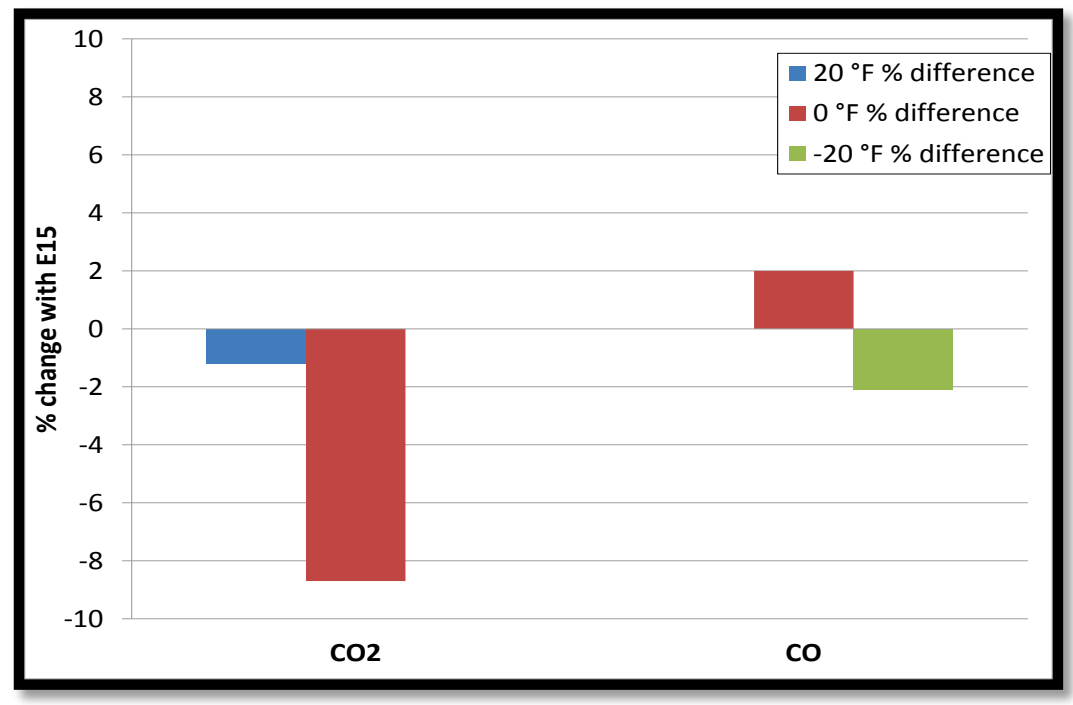

Figure 4.28: Percent change of Polaris emissions when changing to E15

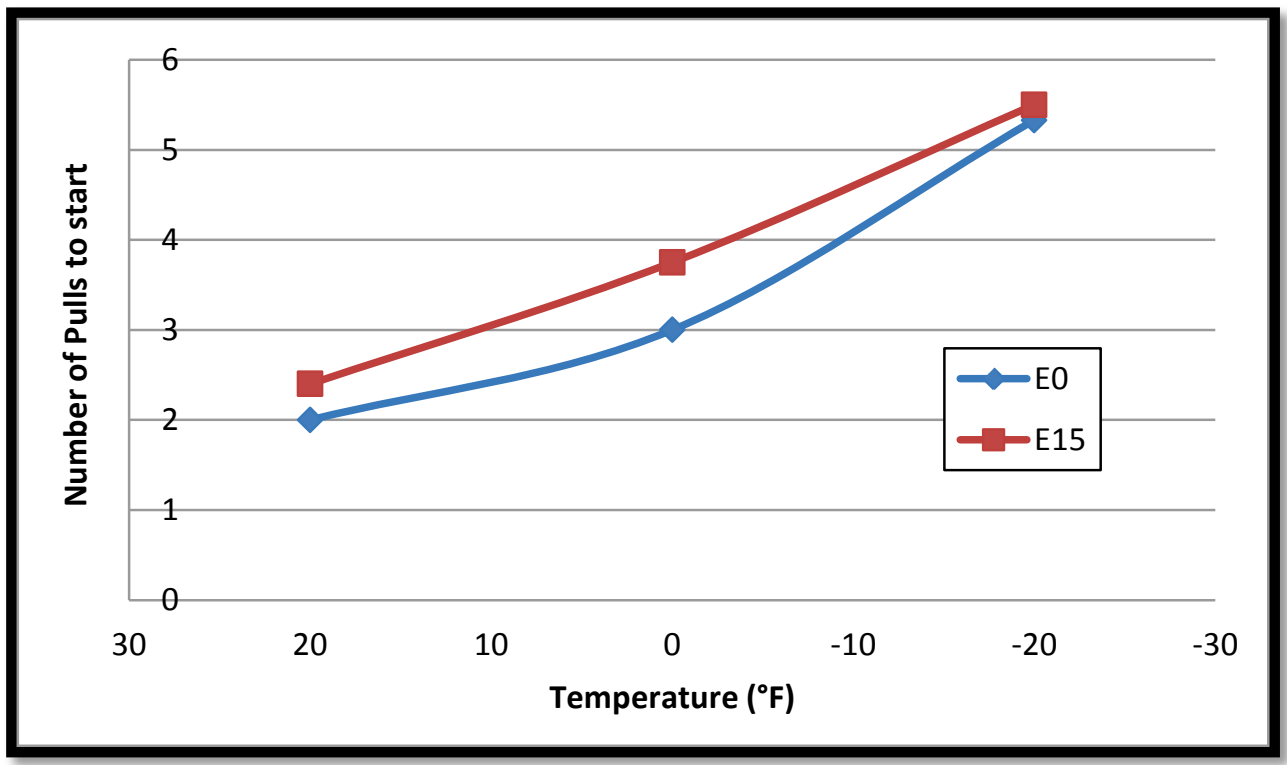

Figure 4.29: Average Polaris cold-start number of pulls required to start engine

\subsubsection{Polaris Emissions}

Changing the resistor to compensate for the different fuels reduced the impact of E15 on emissions. Figure 4.30 shows the $\mathrm{CO}_{2}$ emissions for the Polaris averages for the tests. For $20^{\circ} \mathrm{F}$ and $0{ }^{\circ} \mathrm{F}$, E0 initially reached a higher value of $\mathrm{CO}_{2}$. For $-20{ }^{\circ} \mathrm{F}$, the $\mathrm{CO}_{2}$ emissions for E0 and E15 were fairly equal except for the initial peak that E15 had which 
was slightly higher. All of the $\mathrm{CO}_{2}$ emissions levels settled to approximately $2.5 \%$ at 180 seconds into the test.

Shown in Figure 4.31, are the average CO emissions for each of the tests which were actually higher than the $\mathrm{CO}_{2}$ emissions. As with the $\mathrm{CO}_{2}$ plot, all of the tests were grouped tightly together. At the beginning of the tests, the data increased to about $3.5 \%$, then as time progressed, the $\mathrm{CO}$ emissions increased as the engine temperatures warmed up. In general, at the end of the cold start test the E0 fuels had slightly higher concentrations than E15 at each temperature. The engine calibration appeared to be very rich at idle causing the $\mathrm{CO}$ and $\mathrm{HC}$ emissions to be very high.

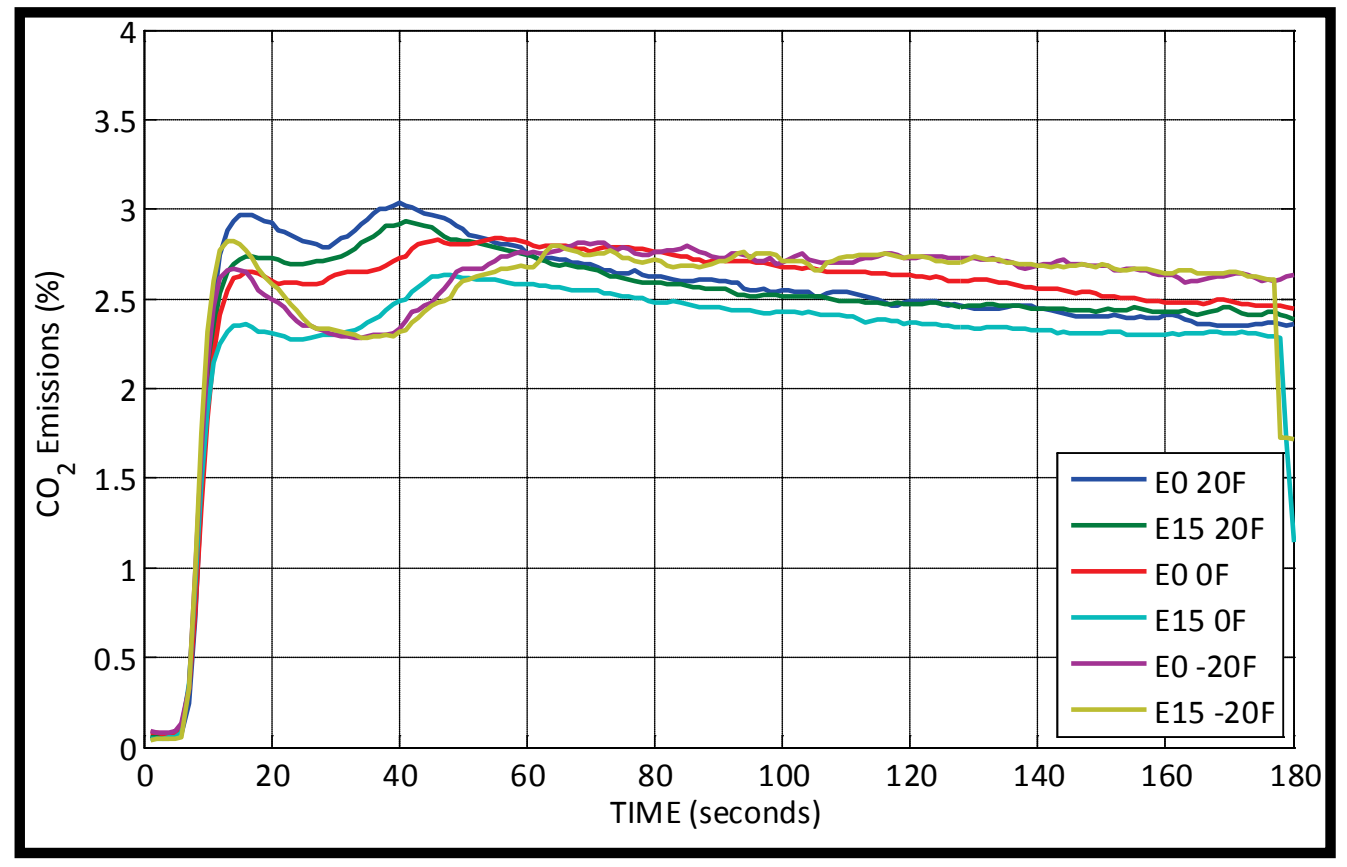

Figure 4.30: Average Polaris cold-start CO2 emissions 


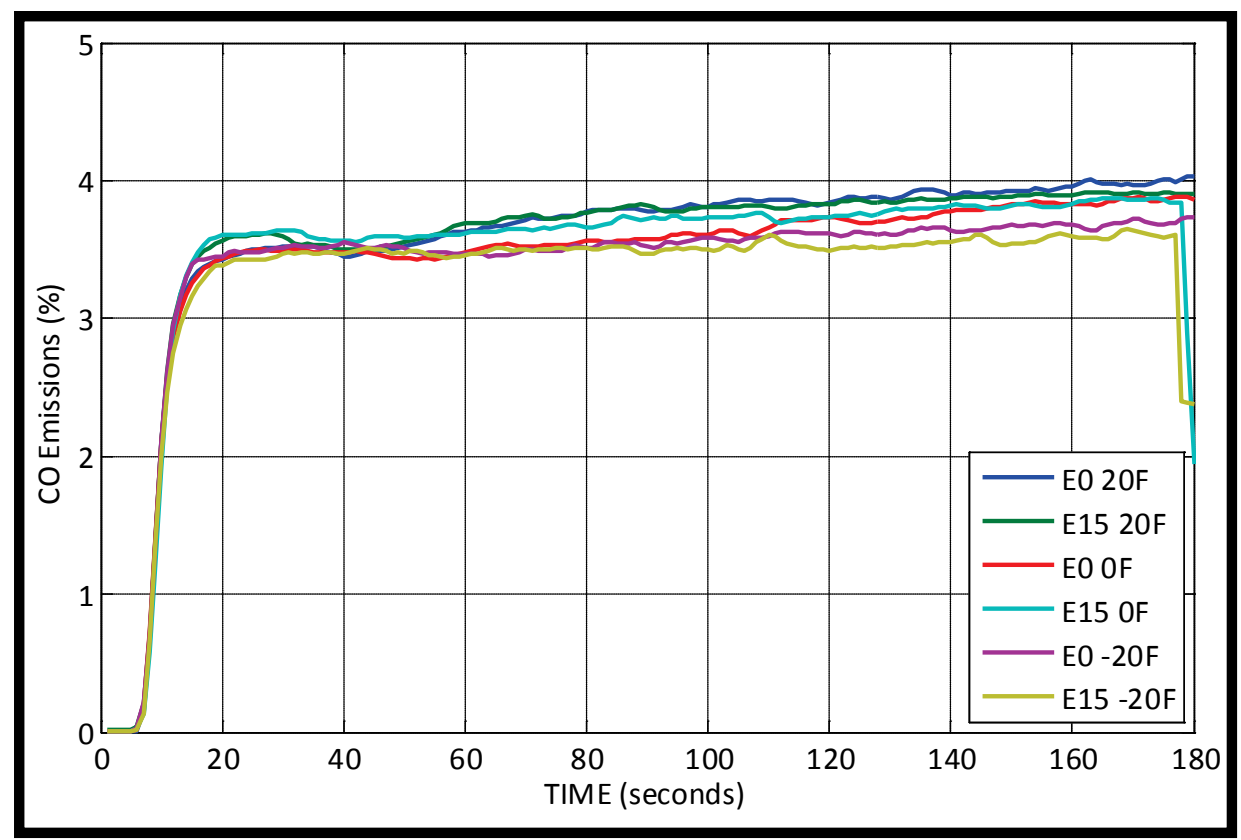

Figure 4.31: Average Polaris CO cold-start emissions

The THC emissions were high enough to exceed the FID analyzer range almost immediately. Figure 4.32 shows how quickly the analyzer range was exceeded during the cold-start event.

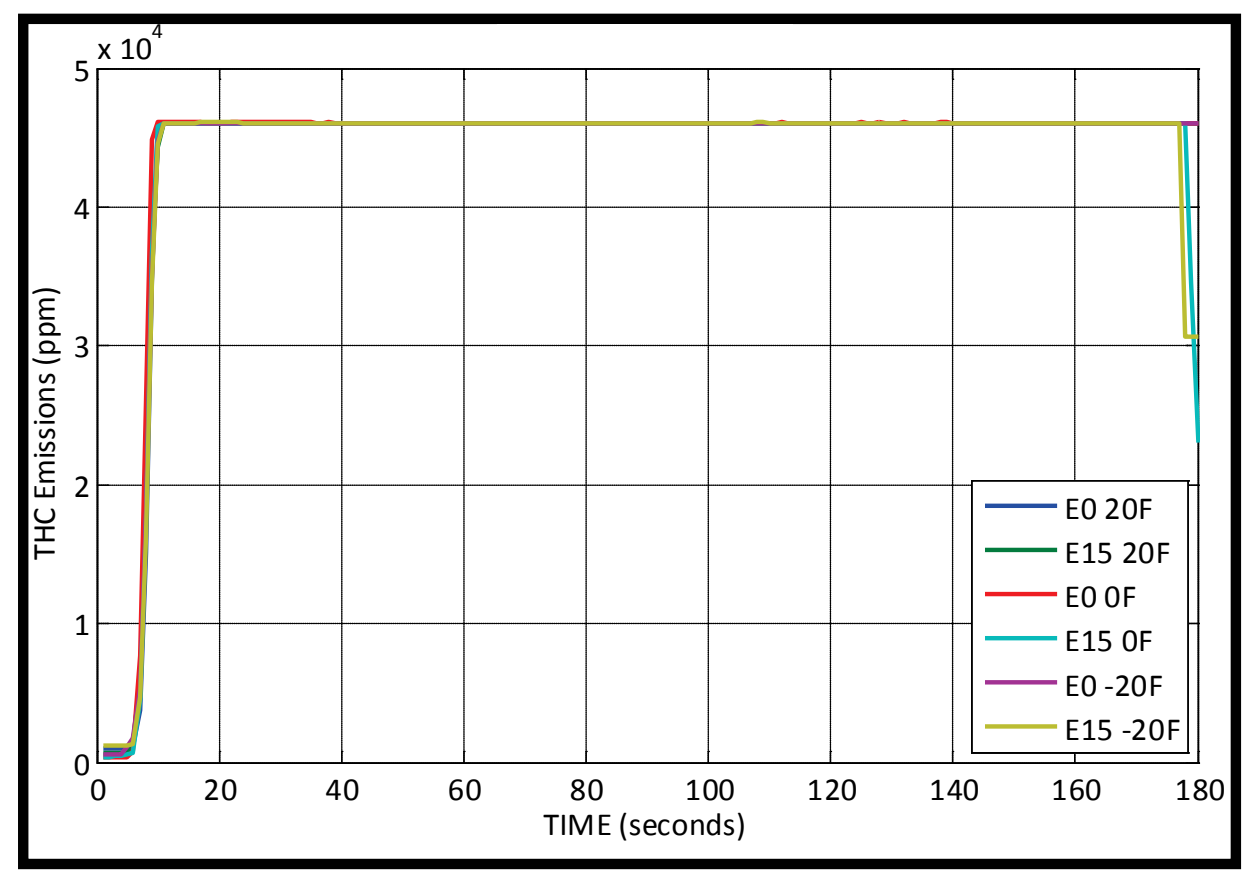

Figure 4.32: Average Polaris cold-start THC emissions 
The following figures show the $\mathrm{O}_{2}$ concentration and air-to-fuel ratios during the cold start tests. The Polaris engine was a two-stroke and therefore had a very high level of unburned fuel and oxygen in the exhaust. Figure 4.33 shows that there was approximately $12 \% \mathrm{O}_{2}$ in the exhaust throughout the tests after the analyzer stabilized. Because the data was so similar among the tests, it is very difficult to characterize the effect of E15.

In Figure 4.34, the air-to-fuel ratios, there are two separate groupings of fuel. The AFR values were approximately 16 for E0 and 15.2 for E15 at 180 seconds.

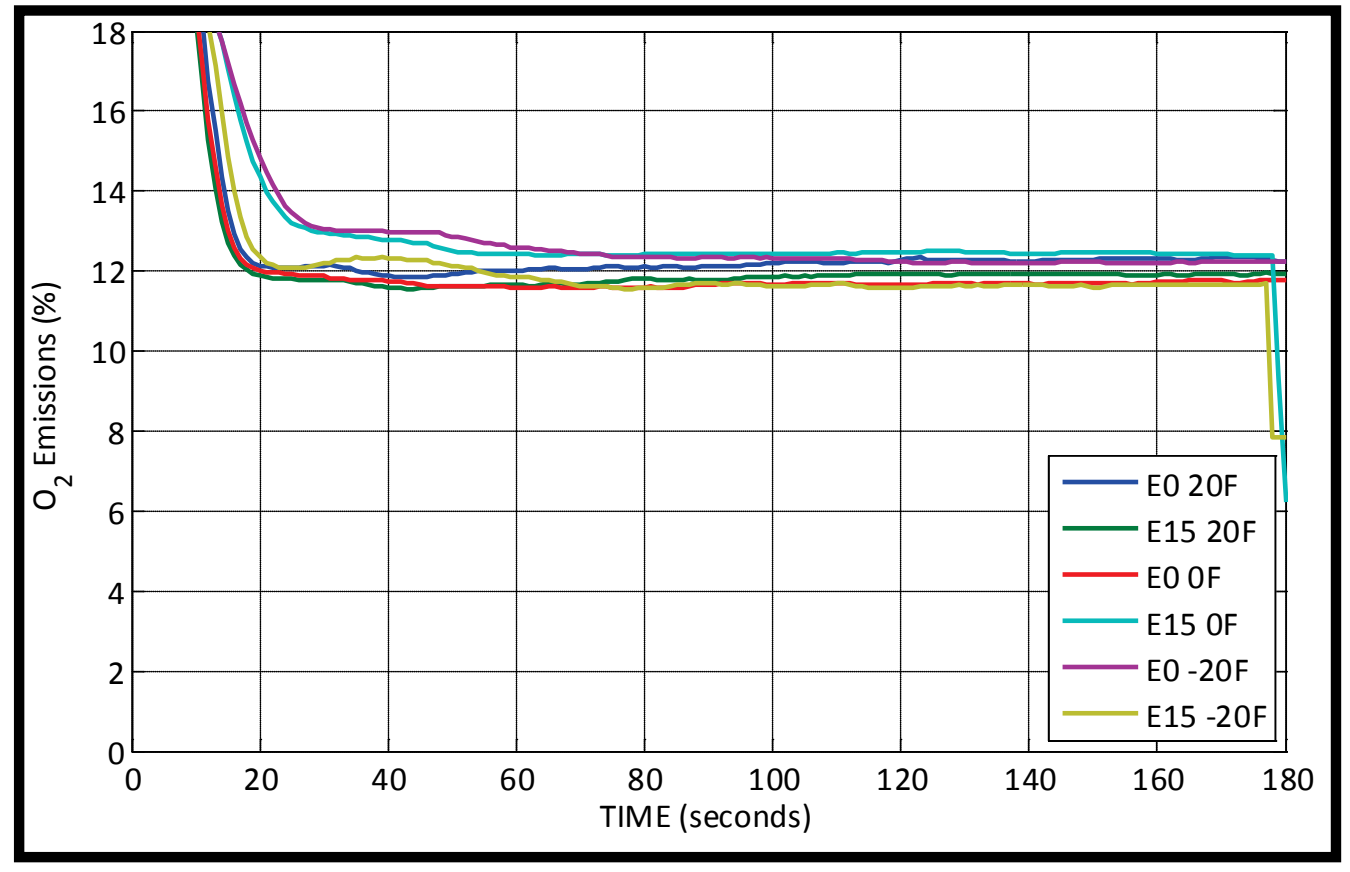

Figure 4.33: Average Polaris cold-start $\mathrm{O}_{2}$ concentration 


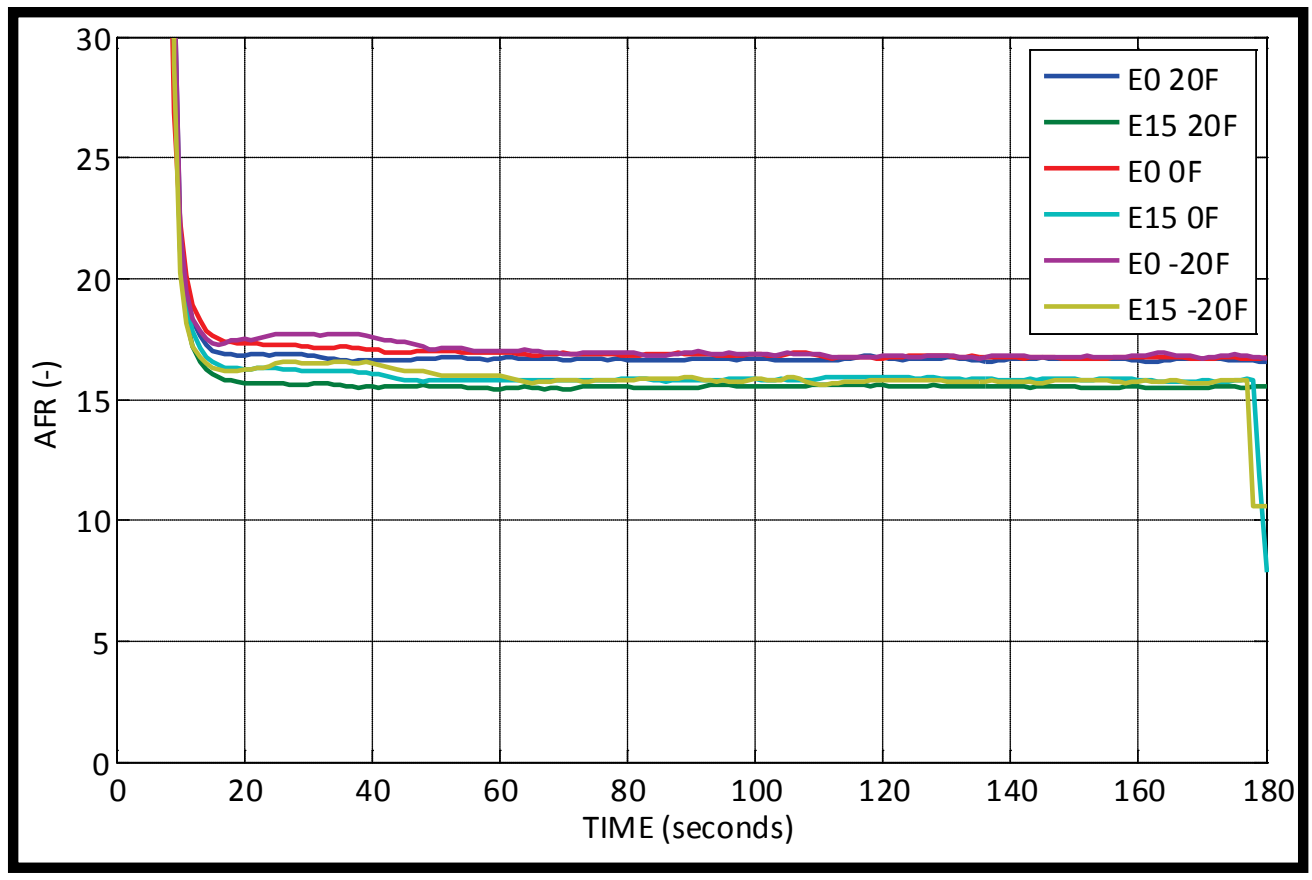

Figure 4.34: Average Polaris cold-start air to fuel ratios

\subsubsection{Polaris Engine Data}

The data in Table 4.6 are average values for the duration of the cold start tests (180 seconds). Figure 4.35 displays the percent difference when the fuel was changed to E15. The engine idle speed data shows that there were no major differences in the values at each temperature with the largest difference being $160 \mathrm{RPM}$ at $0{ }^{\circ} \mathrm{F}$. The engine speed did increase as the temperature decreased as a result of factory calibration. For the same ambient temperature, the coolant temperature did not show a significant difference between the two fuels. The exhaust gas temperatures showed no difference at $20^{\circ} \mathrm{F}$ but at $0{ }^{\circ} \mathrm{F}$ and $-20^{\circ} \mathrm{F}$, the E15 fuel showed a decrease in the average temperature.

Figure 4.36 is a plot of the ambient test cell temperature during the cold-start test. These values are quite stable and only varying $2-3{ }^{\circ} \mathrm{F}$ from each other and from the required temperatures. 
Table 4.6:

Average engine data for Polaris

\begin{tabular}{|c|c|c|c|c|}
\hline & $\begin{array}{c}\text { Test Cell } \\
\text { Temp }\left({ }^{0} \mathbf{F}\right)\end{array}$ & $\begin{array}{c}\text { Engine } \\
\text { Speed (RPM) }\end{array}$ & $\begin{array}{c}\text { Coolant } \\
\text { Temp }\left({ }^{\circ} \mathrm{C}\right)\end{array}$ & $\begin{array}{c}\text { MAG EGT } \\
\left({ }^{\circ} \mathrm{C}\right)\end{array}$ \\
\hline E0 $20^{\circ} \mathrm{F}$ & 22.77 & 2471.09 & -2.51 & 176.02 \\
\hline E15 $20^{\circ} \mathrm{F}$ & 21.96 & 2427.08 & -2.66 & 176.52 \\
\hline $\begin{array}{c}20^{\circ} \mathrm{F} \\
\text { difference }\end{array}$ & $-0.81^{\circ} \mathrm{F}$ & $-1.8 \%$ & $6.0 \%$ & $0.3 \%$ \\
\hline EO $0^{\circ} \mathbf{F}$ & 2.28 & 2539.71 & -13.12 & 160.79 \\
\hline E $150^{\circ} \mathrm{F}$ & 3.15 & 2381.79 & -14.40 & 137.81 \\
\hline $\begin{array}{c}\mathbf{0}^{\circ} \mathbf{F} \\
\text { difference }\end{array}$ & $0.87^{\circ} \mathrm{F}$ & $-6.2 \%$ & $9.8 \%$ & $-14.3 \%$ \\
\hline E0 N20 ${ }^{\circ} \mathrm{F}$ & -21.50 & 2679.69 & -24.27 & 143.15 \\
\hline E15 $\mathrm{N}^{\circ} 0^{\circ} \mathrm{F}$ & -19.70 & 2543.08 & -23.52 & 136.25 \\
\hline $\begin{array}{c}-20{ }^{\circ} \mathrm{F} \\
\text { difference }\end{array}$ & $1.8^{\circ} \mathrm{F}$ & $-5.1 \%$ & $-3.1 \%$ & $-4.8 \%$ \\
\hline
\end{tabular}




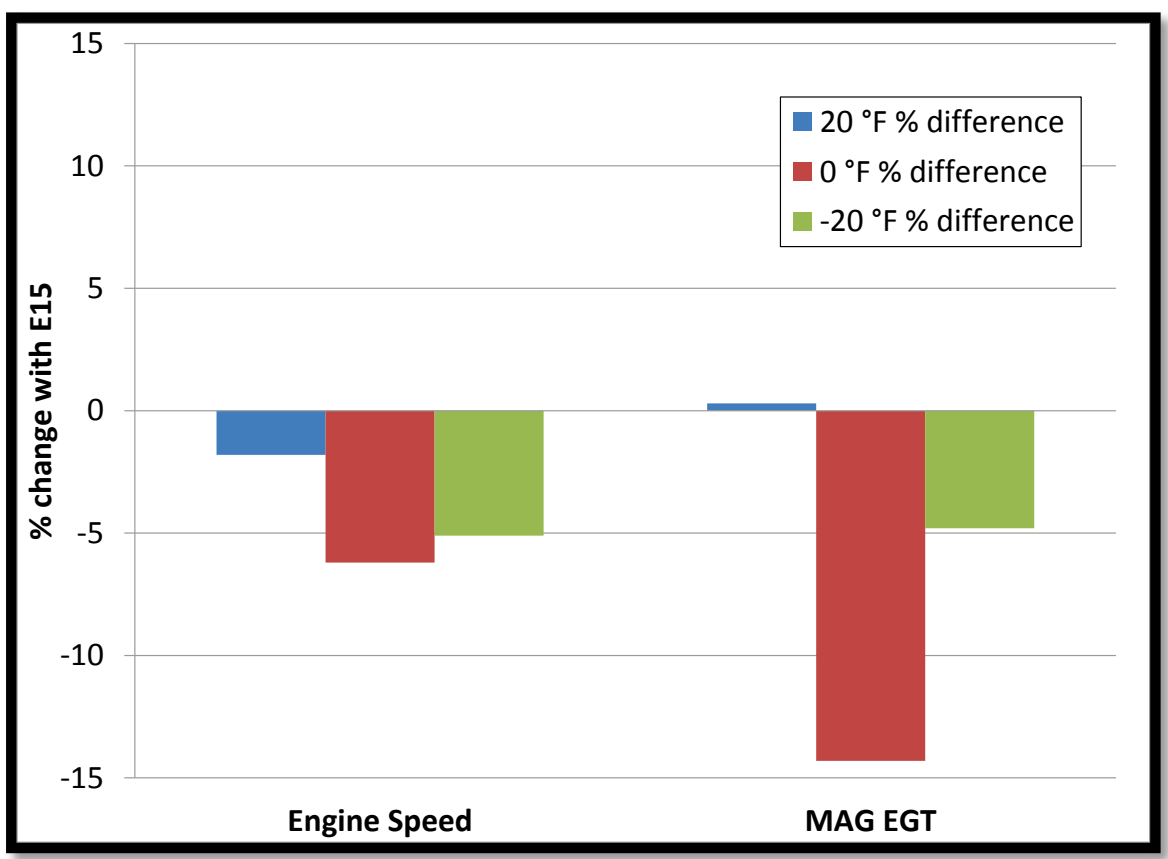

Figure 4.35: Percent change of Polaris engine parameters when changing to E15

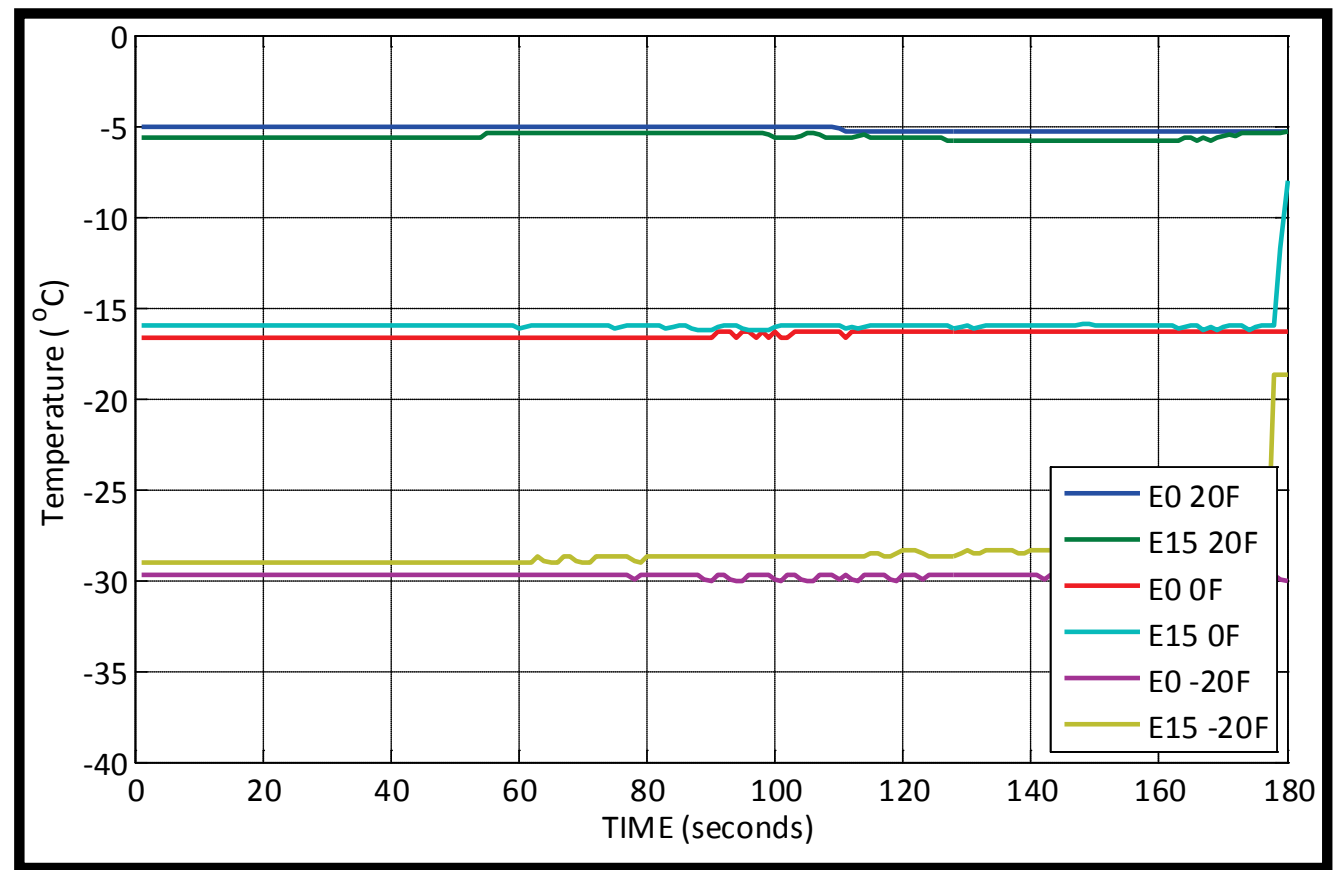

Figure 4.36: Average Polaris cold-start test cell temperature

The engine speed data is shown in Figure 4.37 which revealed different idle speed profiles with changes in ambient temperature and fuel properties. When the engine was 
first started, the speed was constant for approximately 20 seconds, after which it would increase 200-300 RPM. Through the remainder of the tests, the RPM slowly decreased but never reached a steady-state value. The snowmobile may have been in a warm-up phase based on coolant temperature, which would raise the idle speed. The normal, warm idle speed of this engine was approximately 1700 RPM and all of the averaged tests ended between 2300 and 2600 RPM. The colder temperatures had the highest idle speed and along with this trend, the E0 fuel generally had a slightly higher idle speed.

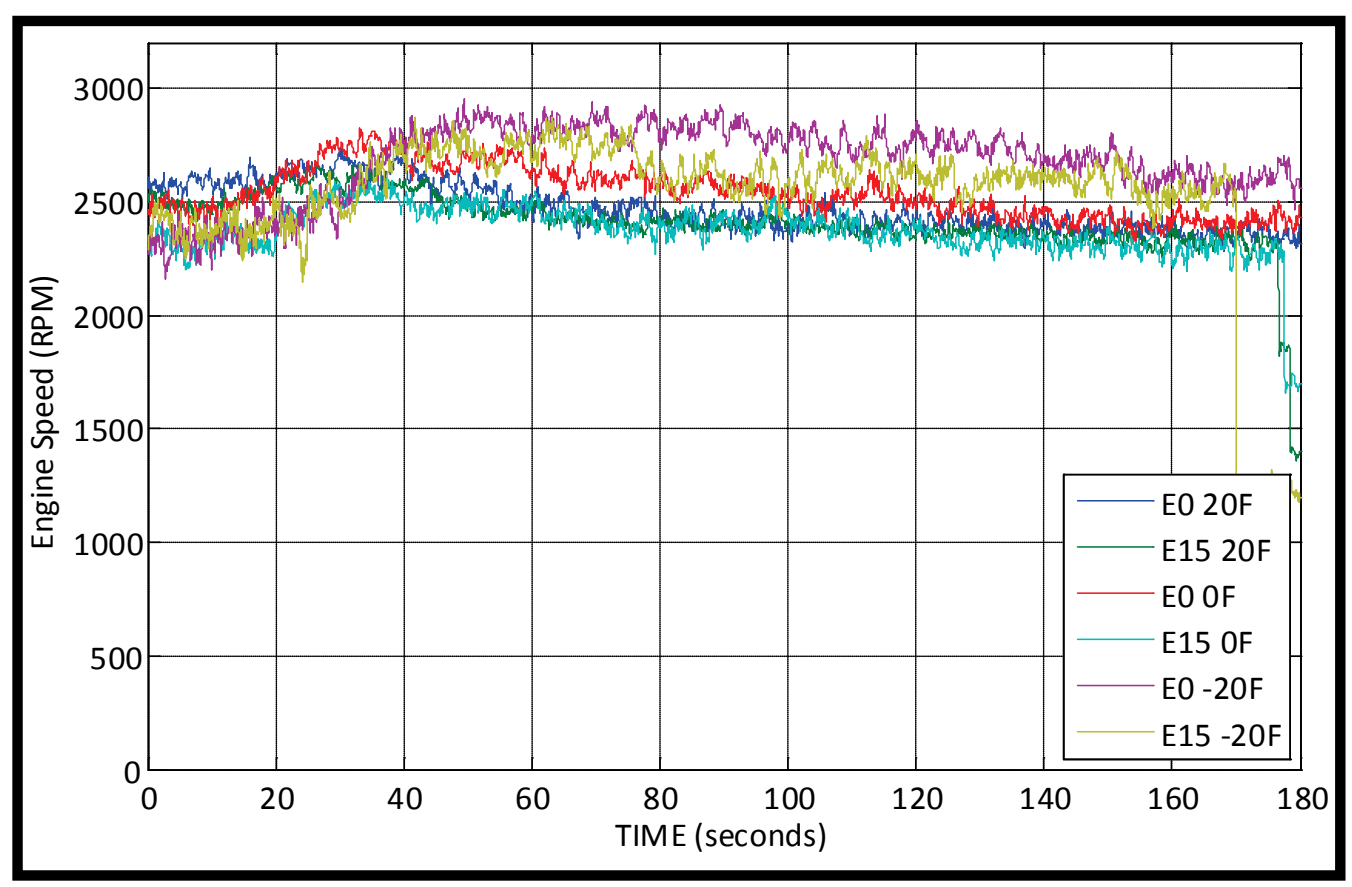

Figure 4.37: Average Polaris cold-start engine speeds

Figure 4.38 shows the engine coolant temperature for the three ambient cold-start conditions for the Polaris. This data provided confidence that the engine was cold-soaked properly at the beginning of each test. This figure also shows that the engine coolant temperatures increased at approximately the same rate and there was no impact of the fuel on this parameter.

The Polaris head was designed with a raised rim around the spark plug and therefore the available equipment was not suitable for obtaining head temperatures without making major modifications to the cylinder head. Figure 4.39 is a plot of the 
EGT averages from the six different temperature and fuel combinations. From the plot, it can be seen that the fuel did not make a difference at $20^{\circ} \mathrm{F}$. For the other two temperatures, E0 had the higher exhaust gas temperature for the duration of the test. The only other trend that was visible in this plot is that for $-20^{\circ} \mathrm{F}$ tests, after the engine fired, the EGTs leveled off at approximately $75{ }^{\circ} \mathrm{C}$ until 30 seconds into the test they started increasing. This may have been caused by the excess fuel being added to start the snowmobile at the $-20{ }^{\circ} \mathrm{F}$ ambient condition. Additional plots of Polaris cold-start data such as ambient pressures and relative humidity are located in Appendix A.16 to Appendix A.21.

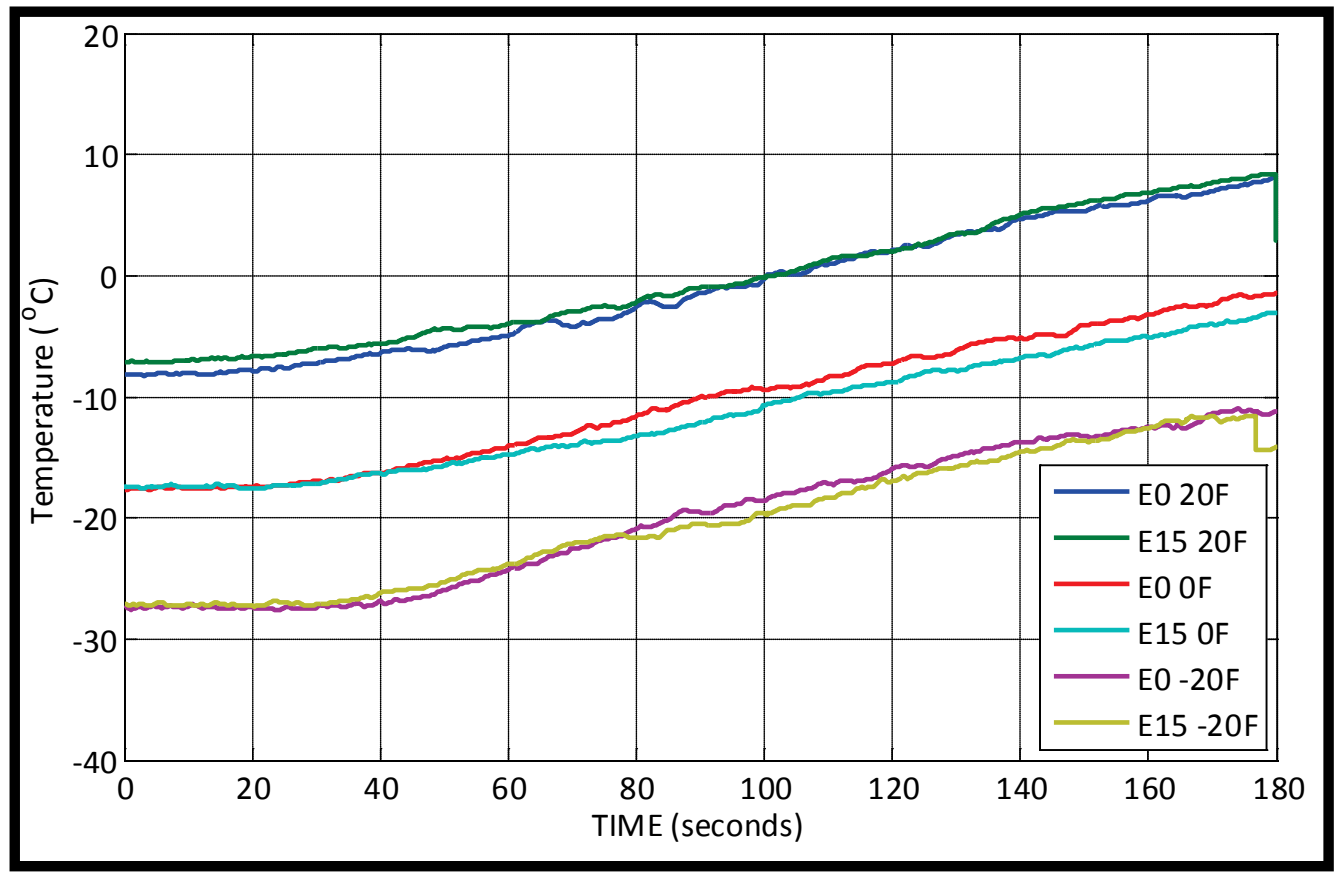

Figure 4.38: Average Polaris cold-start coolant temperatures 


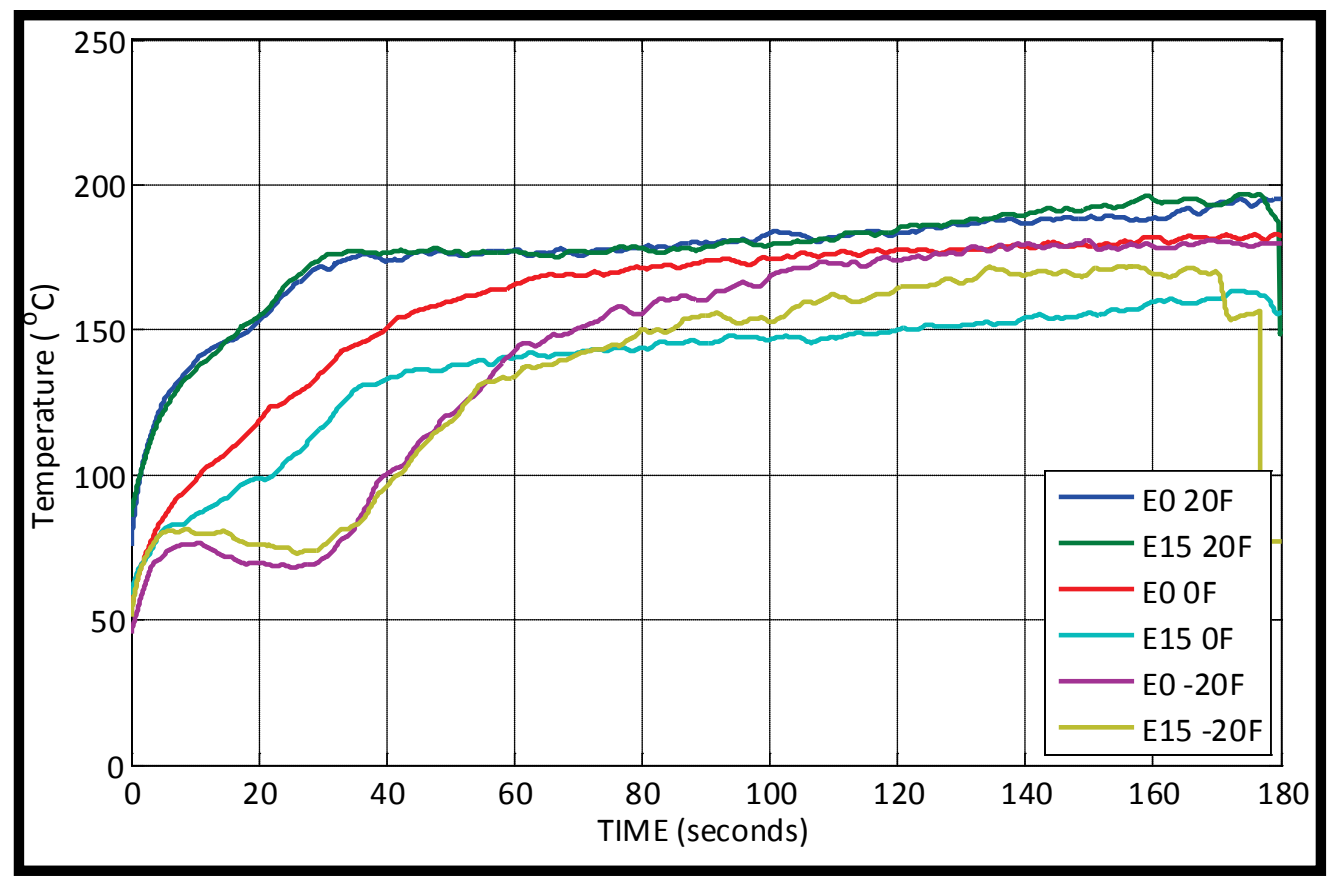

Figure 4.39: Average Polaris cold-start MAG exhaust gas temperatures

\subsection{Arctic Cat F570}

The Arctic Cat F570 snowmobile was expected to have the most interesting and valuable results from the cold-start evaluation. This was because the snowmobile was carbureted and fan cooled, representing the least sophisticated technology of the four vehicles tested. There was no ability to compensate for changes in fuel properties or ambient temperature on this snowmobile. The engine required the use of a manually operated choke to enrichen the fuel delivery and promotes combustion at cold temperatures.

Table 4.7 is the average data from the cold-start test results with the starting information. Figure 4.40 displays the percent change in Arctic Cat emissions when the fuel was changed to E15. $\mathrm{CO}_{2}$ emissions increased with the addition of ethanol at $20^{\circ} \mathrm{F}$ and decreased with E15 at the colder temperatures The CO emissions decreased with E15 at all temperatures. The FID analyzer range was exceeded so there was no useful THC 
data. The $\mathrm{O}_{2}$ in the exhaust was also increased slightly for all temperatures with E15 as the fuel. Figure 4.41 displays the average number of pulls required to start the engine with both fuels.

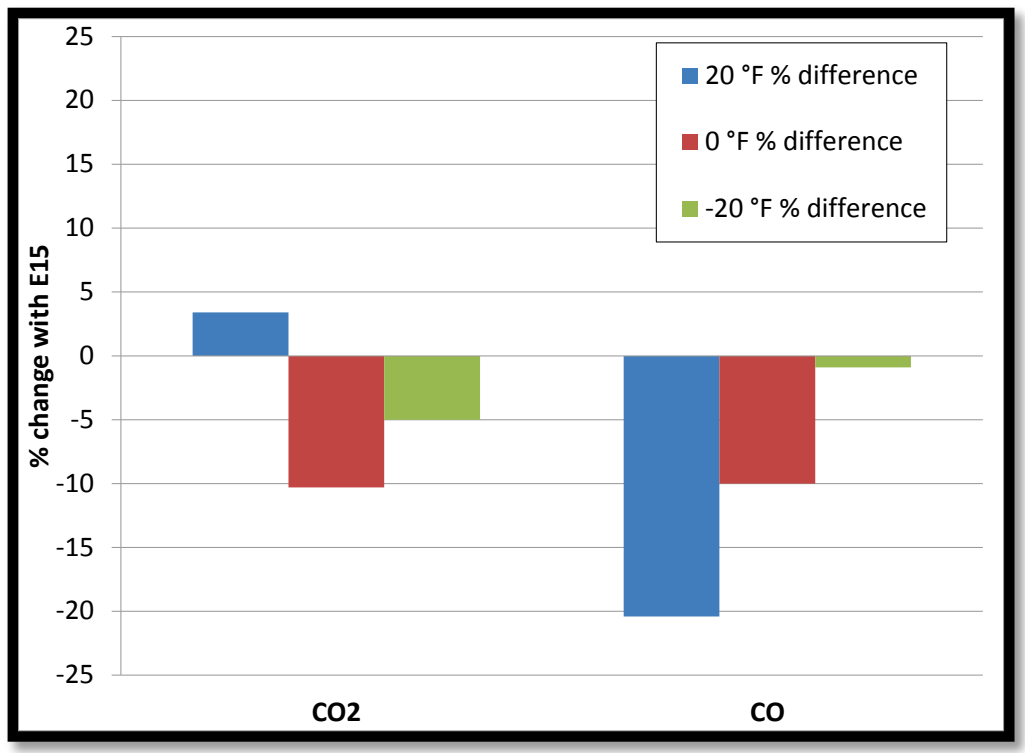

Figure 4.40: Percent change of Arctic Cat emissions when changing to E15

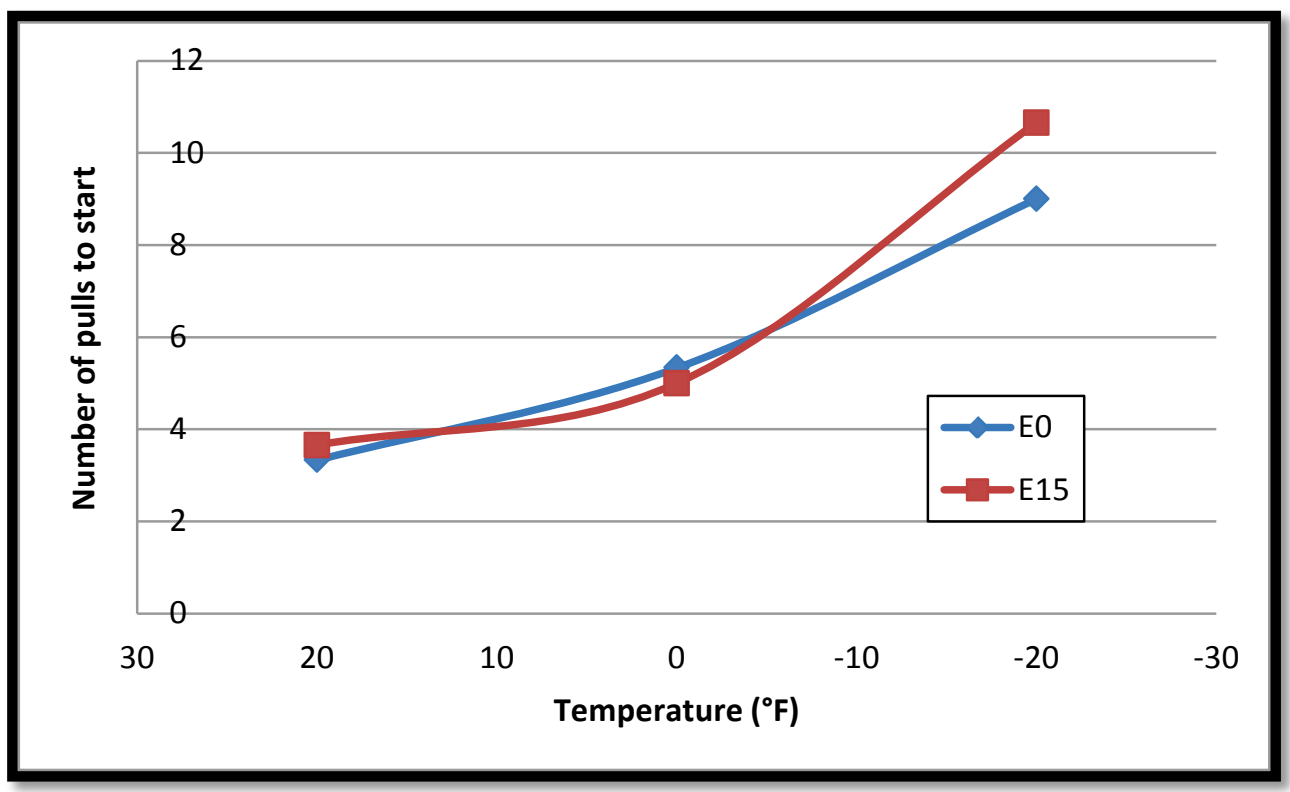

Figure 4.41: Average Arctic Cat cold-start number of pulls required to start engine 
Table 4.7:

Average Arctic Cat cold-start results of emissions and starting data

\begin{tabular}{|c|c|c|c|c|c|c|}
\hline & $\begin{array}{l}\mathrm{CO2} \\
(\%)\end{array}$ & $\begin{array}{l}\text { CO } \\
(\%)\end{array}$ & $\begin{array}{c}\text { THC } \\
(\text { ppm) }\end{array}$ & $\begin{array}{c}\text { O2 } \\
(\%)\end{array}$ & $\begin{array}{c}\text { Number } \\
\text { of Pulls to } \\
\text { start }\end{array}$ & $\begin{array}{l}\text { Time of full } \\
\text { choke }\end{array}$ \\
\hline E0 $20^{\circ} \mathrm{F}$ & 4.08 & 1.81 & Maxed & 11.87 & 3.33 & $\begin{array}{c}7 \text { seconds }+2 \\
(@ 30 \mathrm{sec} .\end{array}$ \\
\hline E15 $20^{\circ} \mathrm{F}$ & 4.22 & 1.44 & Maxed & 12.20 & 3.66 & $\begin{array}{c}7 \text { seconds }+2 \\
\text { @ } 30 \mathrm{sec} .\end{array}$ \\
\hline $\begin{array}{c}20^{\circ} \mathrm{F} \\
\text { difference }\end{array}$ & $3.4 \%$ & $-20.4 \%$ & N/A & $2.8 \%$ & 0.33 pulls & N/A \\
\hline E0 $0^{\circ} \mathrm{F}$ & 4.35 & 1.50 & Maxed & 12.22 & 5.33 & 15 seconds \\
\hline E15 $0^{\circ} \mathrm{F}$ & 3.90 & 1.35 & Maxed & 12.70 & 5 & 15 seconds \\
\hline $\begin{array}{c}\mathrm{O}^{\circ} \mathbf{F} \\
\text { difference }\end{array}$ & $-10.3 \%$ & $-10.0 \%$ & N/A & $3.9 \%$ & -0.33 pulls & N/A \\
\hline E0 N20 ${ }^{\circ} \mathrm{F}$ & 3.23 & 2.21 & Maxed & 13.02 & 9 & $\begin{array}{c}30 \text { seconds }+2 \\
\text { @ } 2 \text { mins. }\end{array}$ \\
\hline $\mathrm{E} 15 \mathrm{~N}^{\circ} 0^{\circ} \mathrm{F}$ & 3.07 & 2.19 & Maxed & 13.18 & 10.66 & $\begin{array}{c}30 \text { seconds }+2 \\
\text { (a) } 2 \text { mins. }\end{array}$ \\
\hline $\begin{array}{c}-20{ }^{\circ} \mathbf{F} \\
\text { difference }\end{array}$ & $-5.0 \%$ & $-0.9 \%$ & N/A & $1.2 \%$ & 1.66 pulls & N/A \\
\hline
\end{tabular}

The starting procedure for the Arctic Cat required considerable iteration to produce consistent results. After much iteration, a consistent method for determining when to turn the choke off was developed that worked for both E0 and E15. The procedure involved setting a fixed time of full choke with E0 that produced a robust start and then remained idling for the duration of the test. If the choke was turned off too soon, the engine would not continue to idle for the full three minutes. If the choke was left on too long, it would provide unnecessary fuel enrichment and affect the emissions. Once an 
acceptable start procedure was determined for E0, it was then tested with E15 to ensure the engine would remain running for the full three minutes.

Table 4.7 shows the average number of pulls to start the engine. For $20^{\circ} \mathrm{F}$ and 0 ${ }^{\circ} \mathrm{F}$ there was little difference in the number of pulls. At $-20^{\circ} \mathrm{F}$, there was a significant difference with E15 needing on average 1 more pull to start the engine. The length of time that the choke was left on for each of the temperatures was also recorded and shown in Table 4.7. At $20^{\circ} \mathrm{F}$ the choke was turned on for 2 seconds after 30 seconds of idle. It was found that at $0{ }^{\circ} \mathrm{F}$ no extra choke was needed after the initial shut off. At $-20^{\circ} \mathrm{F}$, a two second choke at 2 minutes was found useful to keep the engine running. The choke operation for both fuels was the same to enable direct comparison of the results.

\subsubsection{Arctic Cat Emissions}

With the Arctic Cat being carbureted and not changing any of the jets for the different fuels, significant changes in the emissions would be expected. However, having the human input of turning the choke off and when to turn it back on adds a large amount of variability in the tests. This operation of the choke lever made it difficult to ensure the engine was running at its optimal air-to-fuel ratio. It could have been possible that the enrichment of the engine via choke lever could have loaded the engine up with too much fuel that would not be cleared out until the cleanout process. Figure 4.42 shows the average $\mathrm{CO}_{2}$ emissions from the Arctic Cat for all the temperature and fuel combinations with increasing levels as the temperature decreased. The large drops in $\mathrm{CO}_{2}$ emissions for the $20{ }^{\circ} \mathrm{F}$ and $-20{ }^{\circ} \mathrm{F}$ ambient conditions are where the choke was turned on for two seconds. Note no drop in $\mathrm{CO}_{2}$ was observed for the $0{ }^{\circ} \mathrm{F}$ because a secondary choke application was not required to keep the engine running. The large drops in $\mathrm{CO}_{2}$ were possibly caused by the engine operating richer as a result of having the choke on. The $\mathrm{CO}_{2}$ emissions were fairly close for the duration of the test until the last 80 seconds which is where the E15 fuel trends downwards when compared to the E0 fuel. The largest difference was for the $0{ }^{\circ} \mathrm{F}$ data at which there was close to $1.3 \%$ difference at 180 
seconds. It appears that most of the averages had not leveled off at any point which leads to longer testing times required to discover at what point $\mathrm{CO}_{2}$ emissions would reach a steady state.

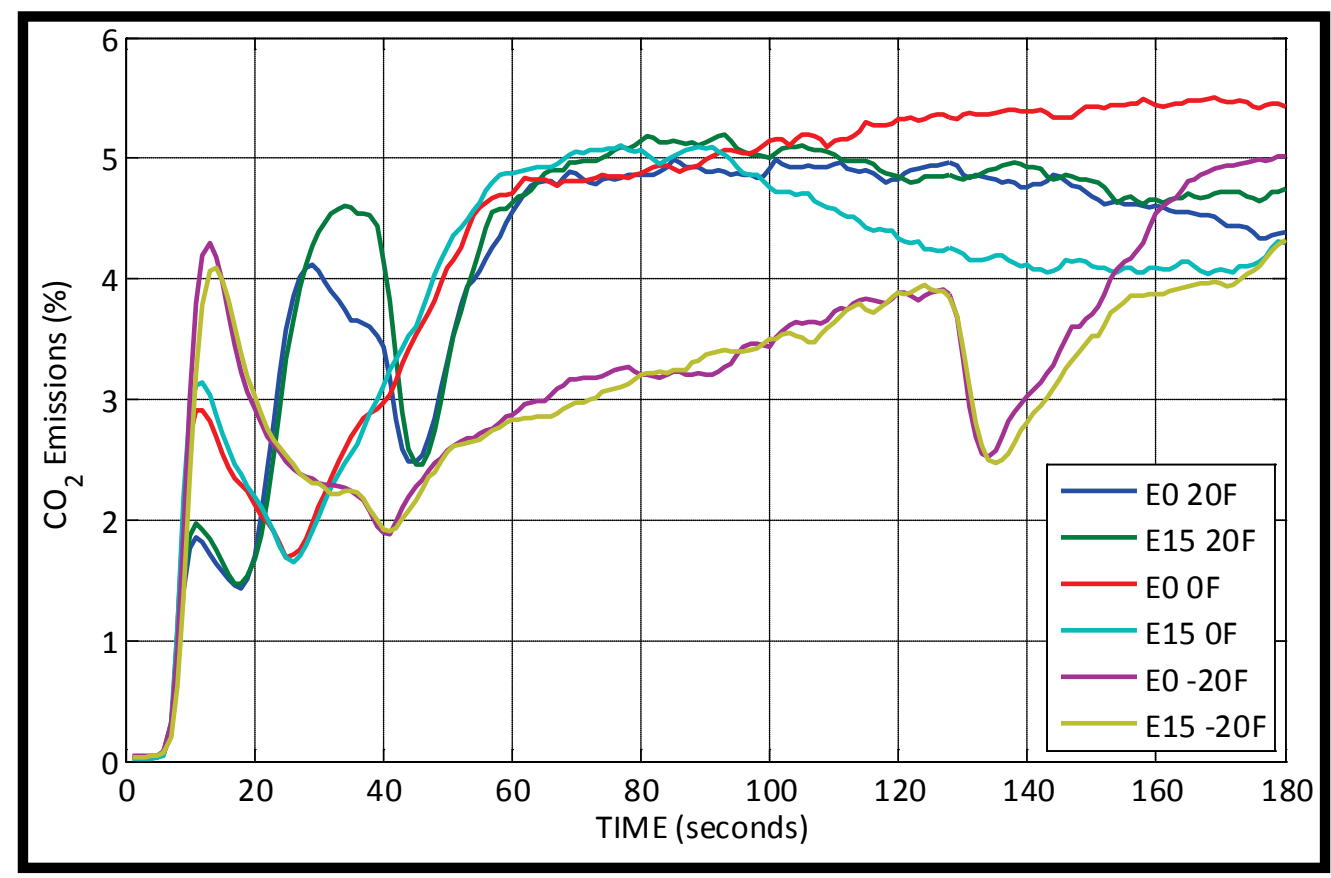

Figure 4.42: Average Arctic Cat cold-start $\mathrm{CO}_{2}$ emissions

The $\mathrm{CO}$ emissions are shown in Figure 4.43 in which all of the averages remained below $3.5 \%$. The second increases in $\mathrm{CO}$ emissions after the initial peaks for $20^{\circ} \mathrm{F}$ and $20{ }^{\circ} \mathrm{F}$ correspond to the two second choke. The increases in $\mathrm{CO}$ emissions were a product of the choke richening the engine, which is caused by not enough oxygen mixing with the fuel at the lower temperatures. The $\mathrm{CO}$ emission trends align with the $\mathrm{CO}_{2}$ trends. For $\mathrm{CO}$ emissions at the beginning of the tests it was difficult to see a difference between the two fuels at any temperature. At $20^{\circ} \mathrm{F}$ after the choke was turned on at 30 seconds, the E0 fuel had a much higher concentration of $\mathrm{CO}$ when compared to the E15 fuel. For the 0 ${ }^{\circ} \mathrm{F}$ averages, with no additional choke, the $\mathrm{CO}$ emissions were similar throughout the test until the last 120 seconds when the $\mathrm{E} 0$ fuel had a slightly higher concentration. At $-20^{\circ} \mathrm{F}$, the two fuels had close to the same $\mathrm{CO}$ concentration but after the choke was turned on, the E15 fuel had approximately $0.8 \%$ higher amount of $\mathrm{CO}$ at 180 seconds. This data also 
shows that the majority of the averages never reached a stable concentration. Longer tests would have to be taken to determine the steady-state concentration.

The Arctic Cat snowmobile had a two-stroke engine with carburetion and therefore the THC emissions were expected to be quite high. Figure 4.44 shows that the Semtech DS FID analyzer range was exceeded almost immediately and therefore, no trends were able to be drawn from the data.

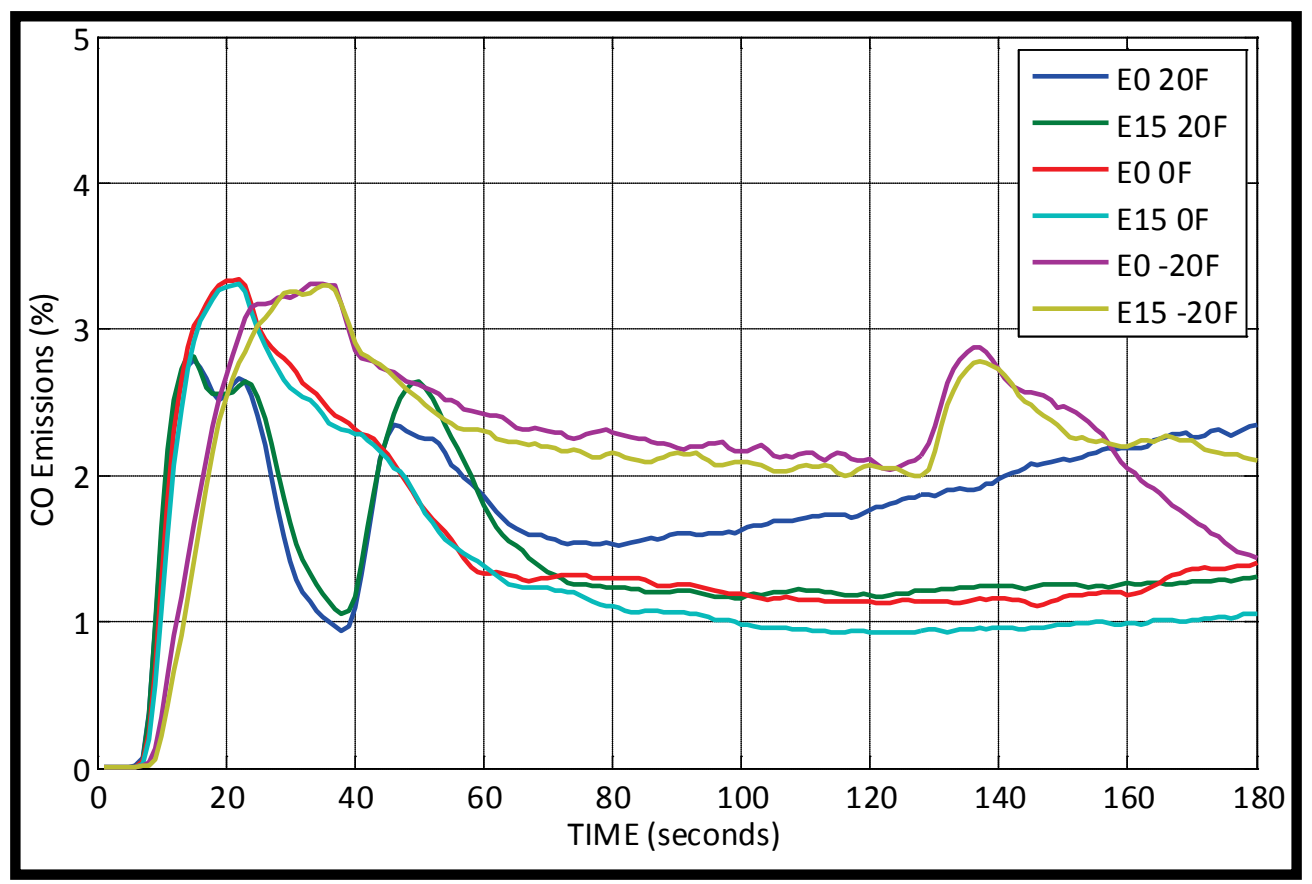

Figure 4.43: Average Arctic Cat cold-start CO emissions 


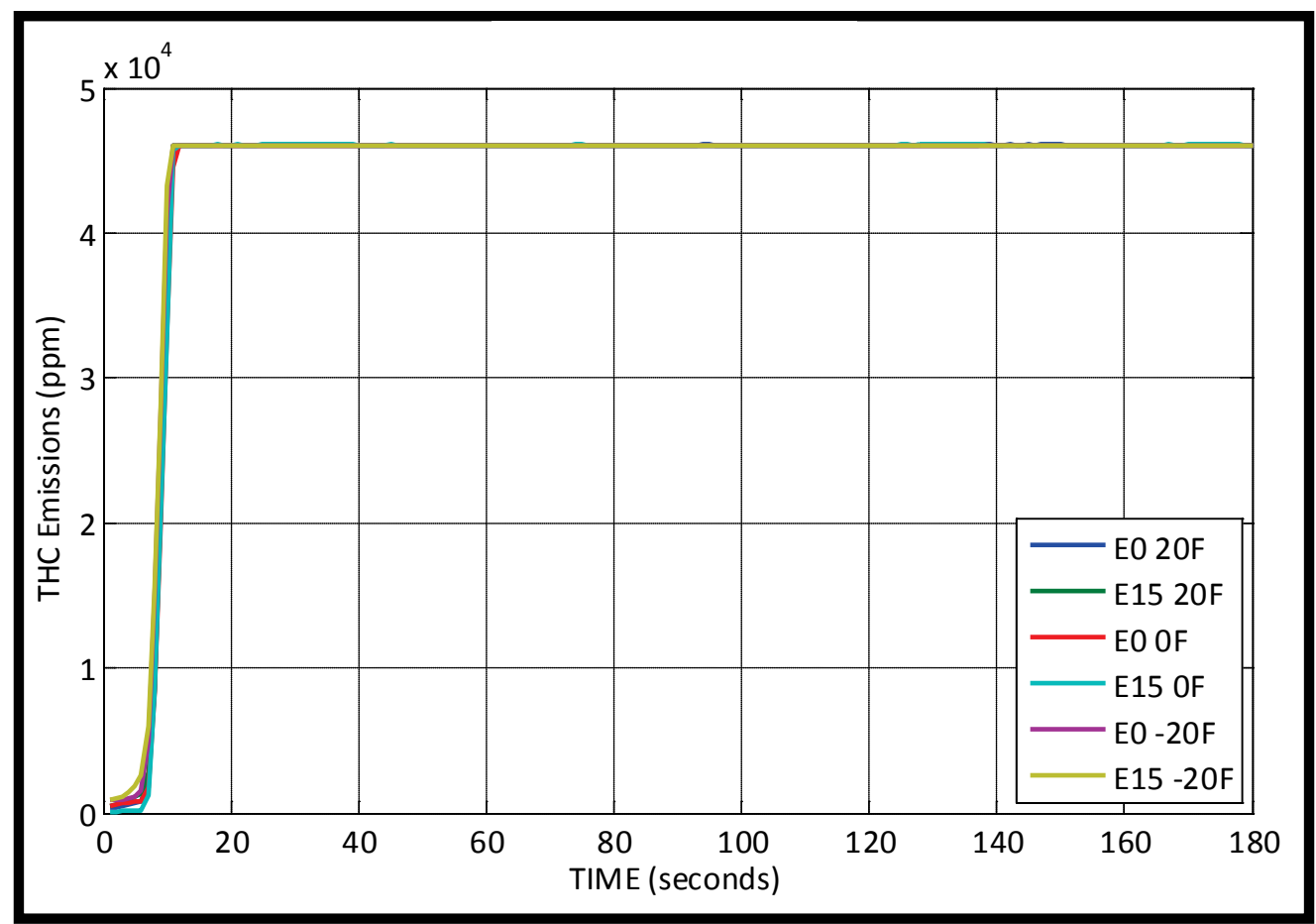

Figure 4.44: Average Arctic Cat cold-start THC emissions

The $\mathrm{O}_{2}$ concentration in the exhaust of the Arctic Cat was the result of short circuiting of the air through the engine at the idle condition. Figure 4.45 shows the $\mathrm{O}_{2}$ concentration of the cold start tests. Towards the end of all of the tests, the E15 fuel had a higher value of $\mathrm{O}_{2}$ at each temperature. Figure 4.46 shows the air-to-fuel ratios of the cold start tests which proved that the fuels did not make a difference in the AFR in the end of the tests. E0 produced the higher AFR values during the first part of the tests. The tests stabilized between $10 \%$ and $12.5 \% \mathrm{O}_{2}$ concentration. 


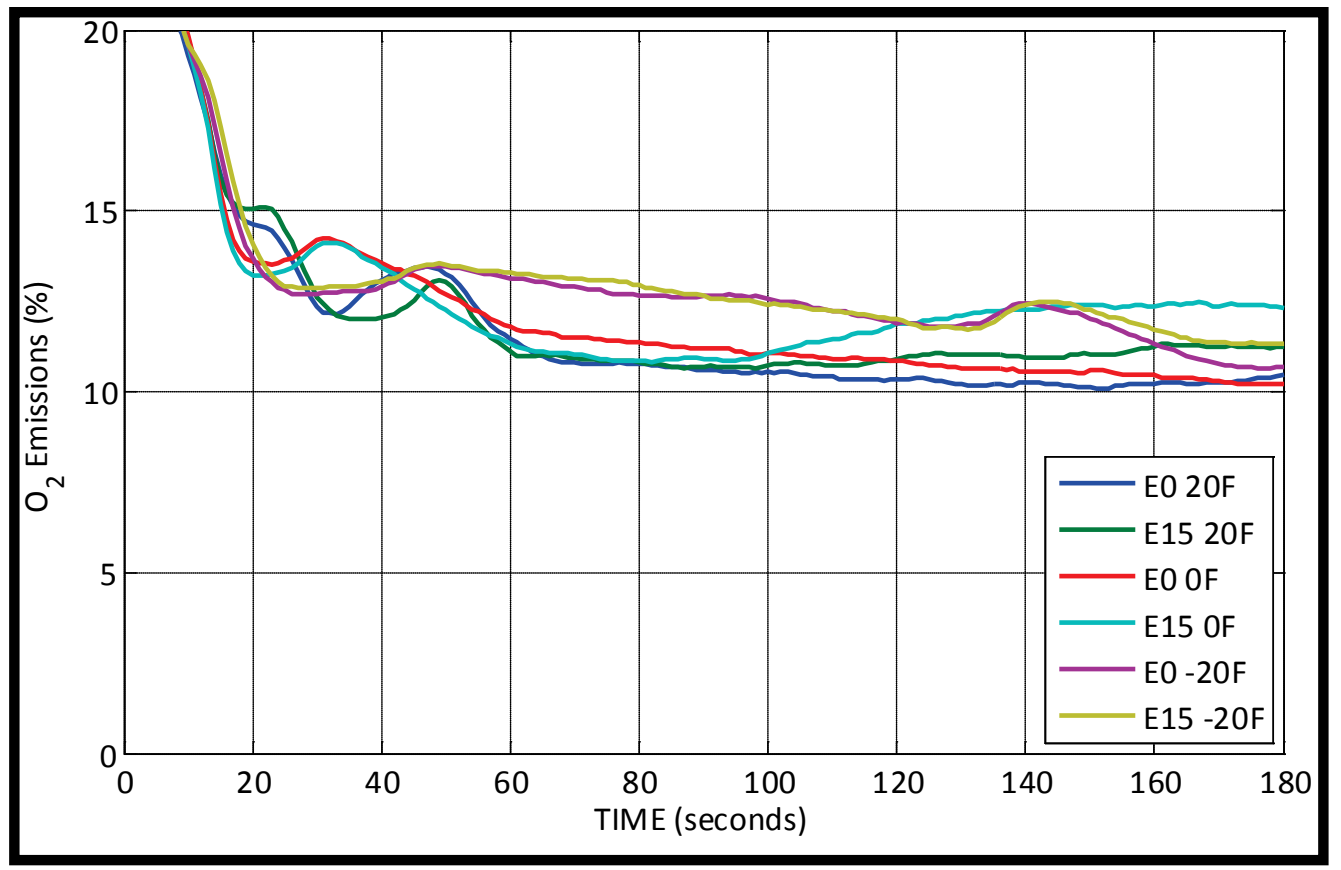

Figure 4.45: Average Arctic Cat cold-start $\mathrm{O}_{2}$ concentrations

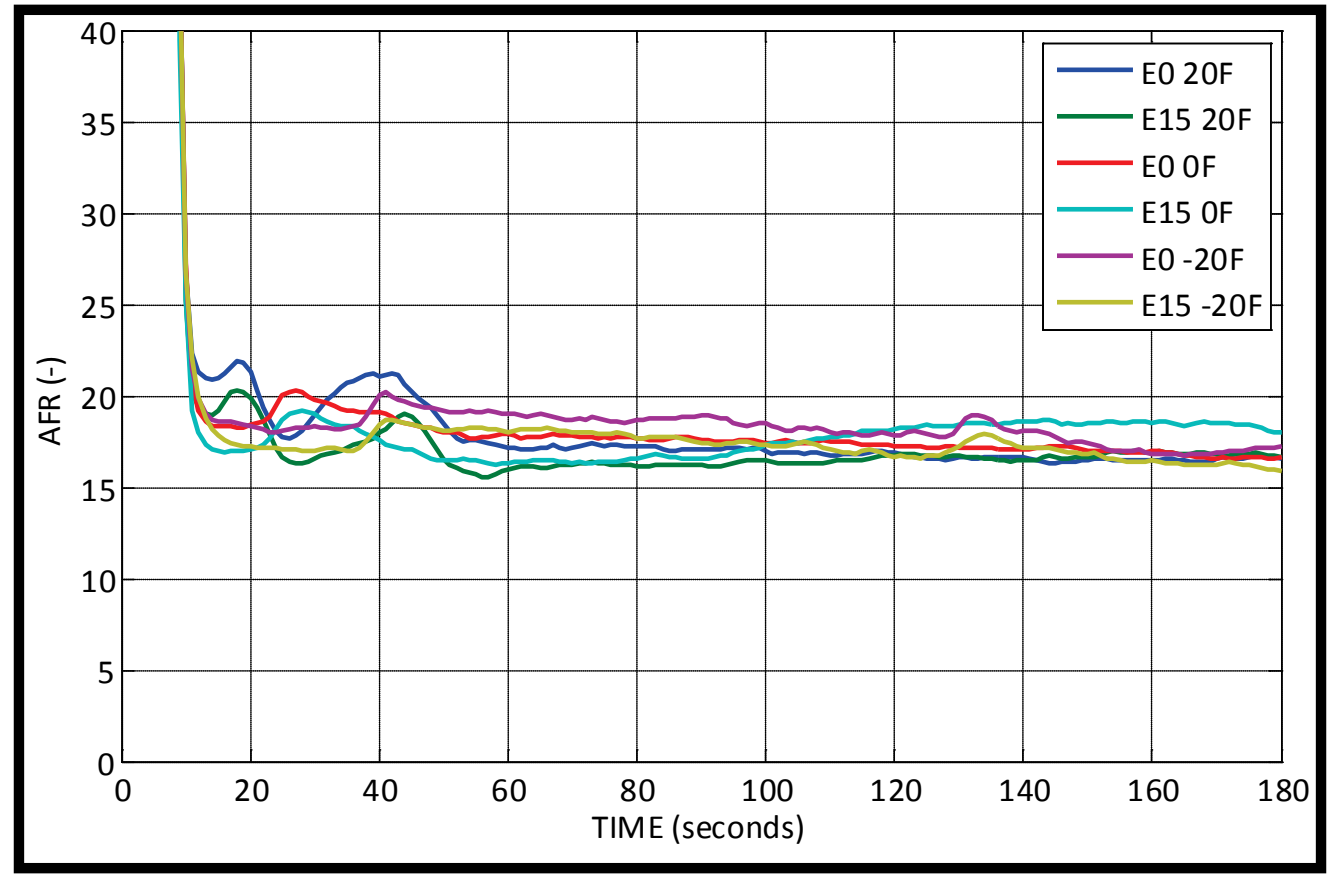

Figure 4.46: Average Arctic Cat cold-start air-to-fuel ratios 


\subsubsection{Arctic Cat Engine Data}

Table 4.8 shows the average engine data that was taken during the cold start tests. Figure 4.47 displays the percent change in engine speed and exhaust gas temperatures when the fuel was changed to E15. These averages help explain the effect of E15 when compared to E0. The engine speed averages show that the E15 fuel consistently had lower values between 100 and 200 RPM. The engine air temperatures did not show a large difference with only $0.28{ }^{\circ} \mathrm{C}$ as the largest difference in the temperature between

the two fuels. The head temperatures and the exhaust gas temperatures at $20^{\circ} \mathrm{F}$ and -20 ${ }^{\circ} \mathrm{F}$ had roughly the same values. At $0^{\circ} \mathrm{F}$ there was a fairly significant difference between the two fuels of $3.14^{\circ} \mathrm{F}$. E15 had the lower head temperatures and is further explained in the following figures.

Table 4.8:

Average Arctic Cat engine data

\begin{tabular}{|c|c|c|c|c|c|}
\hline & $\begin{array}{c}\text { Atm. Temp } \\
\left({ }^{0} \mathbf{F}\right)\end{array}$ & $\begin{array}{l}\text { Engine } \\
\text { Speed } \\
\text { (RPM) }\end{array}$ & $\begin{array}{c}\text { Air Temp } \\
\text { leaving } \\
\text { engine }\left({ }^{\circ} \mathrm{C}\right)\end{array}$ & $\begin{array}{c}\text { PTO } \\
\text { Head } \\
\text { Temp } \\
\left({ }^{\circ} \mathrm{C}\right)\end{array}$ & $\begin{array}{c}\text { PTO EGT } \\
\left({ }^{\circ} \mathrm{C}\right)\end{array}$ \\
\hline E0 $20^{\circ} \mathrm{F}$ & 19.86 & 2063.00 & -0.93 & 22.20 & 221.84 \\
\hline E15 $20^{\circ} \mathrm{F}$ & 20.21 & 1877.99 & -0.95 & 21.74 & 228.80 \\
\hline $\begin{array}{c}20^{\circ} \mathbf{F} \\
\text { difference }\end{array}$ & $0.35^{\circ} \mathrm{F}$ & $-9.0 \%$ & $2.2 \%$ & $-2.1 \%$ & $3.1 \%$ \\
\hline E0 $0^{\circ} \mathrm{F}$ & -0.55 & 2252.73 & -10.95 & 12.62 & 216.82 \\
\hline $\mathbf{E} 150^{\circ} \mathrm{F}$ & -1.40 & 1970.26 & -11.23 & 9.48 & 193.43 \\
\hline $\begin{array}{c}\mathbf{0}^{\circ} \mathbf{F} \\
\text { difference }\end{array}$ & $-0.85^{\circ} \mathrm{F}$ & $-12.5 \%$ & $2.6 \%$ & $-24.9 \%$ & $-10.8 \%$ \\
\hline E0 $-20^{\circ} \mathrm{F}$ & -20.40 & 2290.19 & -20.21 & 0.44 & 200.15 \\
\hline E15 -20 ${ }^{\circ} \mathrm{F}$ & -18.78 & 2178.80 & -20.16 & 0.34 & 200.47 \\
\hline $\begin{array}{c}-20^{\circ} \mathbf{F} \\
\text { difference }\end{array}$ & $-1.62^{\circ} \mathrm{F}$ & $-4.9 \%$ & $-0.2 \%$ & $-22.7 \%$ & $0.2 \%$ \\
\hline
\end{tabular}




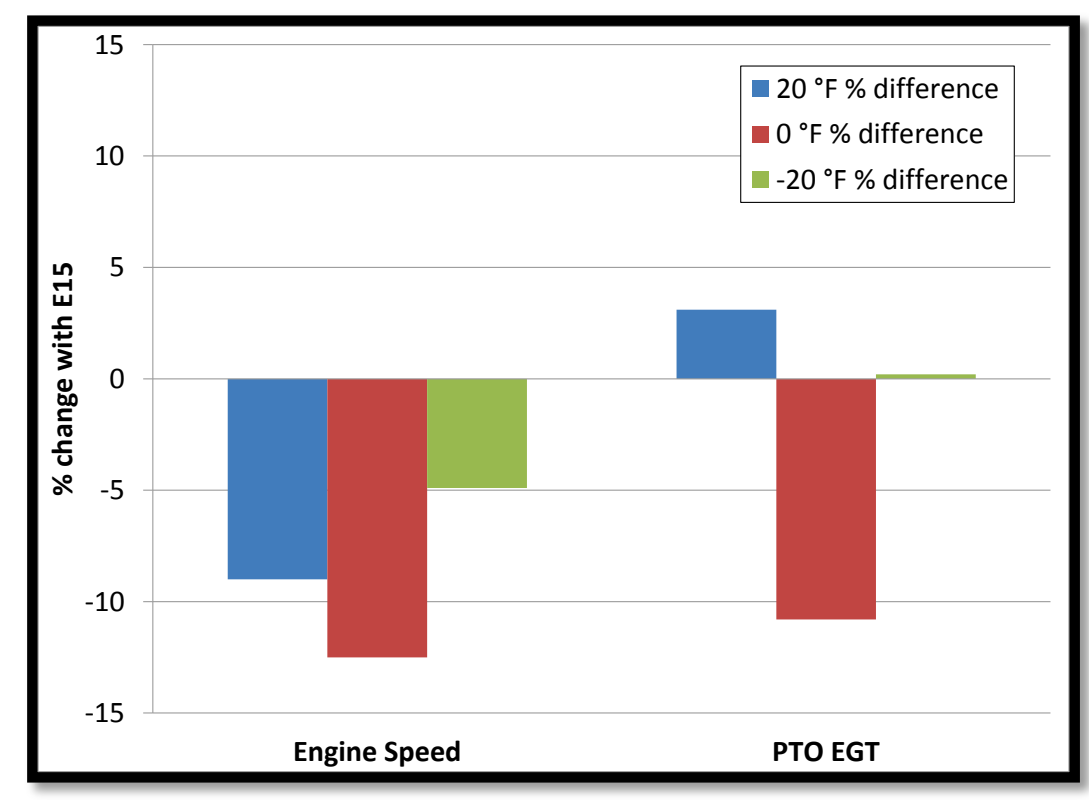

Figure 4.47: Percent change of Arctic Cat engine parameters when changing to E15

Figure 4.48 shows the ambient test cell temperature during the cold-start tests. These values are quite stable and only varying $2-3{ }^{\circ} \mathrm{F}$ from each other and from the required temperatures.

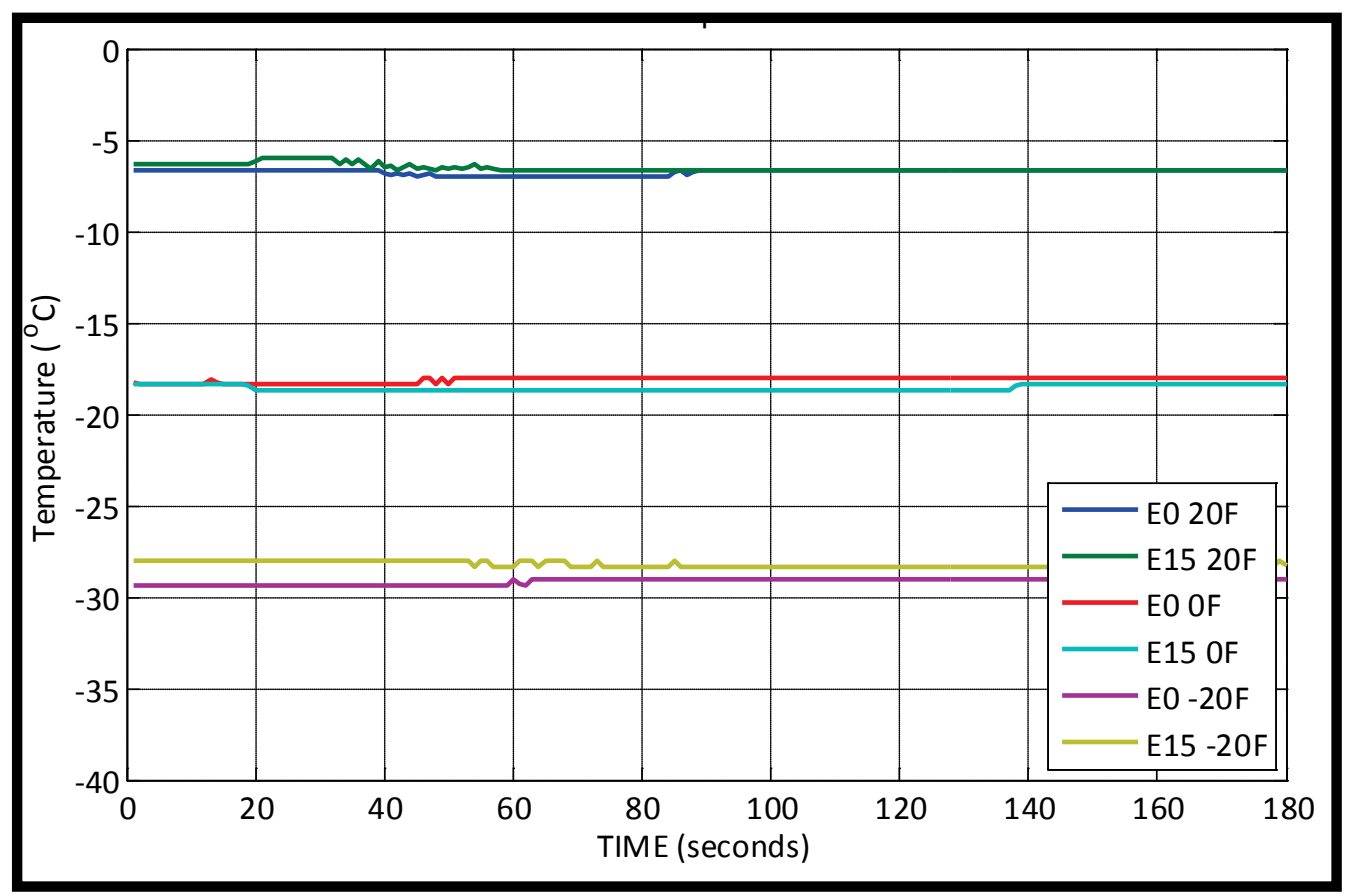

Figure 4.48: Average Arctic Cat cold-start test cell temperatures 
The engine speed averages for the cold start tests are shown in Figure 4.49. The initial part of $20^{\circ} \mathrm{F}$ was very different than the other two temperatures. The RPM decreases when the engine starts and the other temperatures increase. All temperatures initially have small differences between fuels. However after the choke was turned off for the $20^{\circ} \mathrm{F}$ test at E0, the engine idles down faster than the E15 fuel did. After the choke was flipped on at 30 seconds, the E15 fuel idled down to a lower value and stabilized at about 1700 RPM. The $0{ }^{\circ} \mathrm{F}$ averages were very similar until 80 seconds in which the E15 fuel idled down to about 1700 RPM. For the $-20{ }^{\circ} \mathrm{F}$ tests the engine speed was similar until the choke was flipped on at 120 seconds. After the choke was turned on, the E15 fuel had a lower engine speed for the remainder of the test. At 180 seconds, only two of the averages had idled down to the normal idle RPM, the others had not reached a steady engine speed. The differences in engine speed help explain some of the differences in previous emission figures.

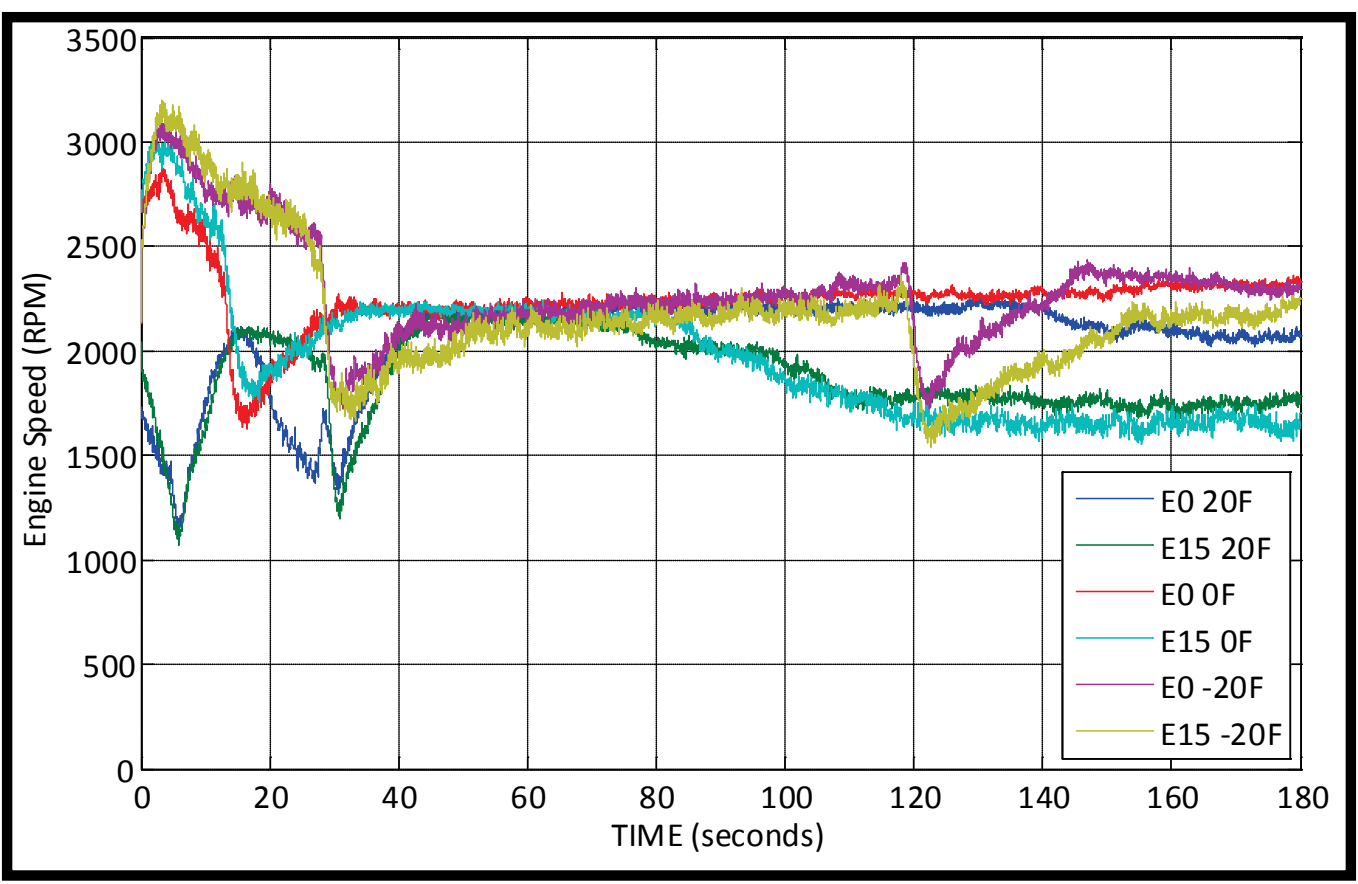

Figure 4.49: Average Arctic Cat cold-start engine speed 
There was no useful data displayed in the air temperature leaving the engine. This data is shown in Figure 4.50. It does show that the initial temperatures were consistent between fuels.

The head temperatures on a fan cooled engine are very important to determine if one cylinder is not running correctly. When looking at Figure 4.51 of the PTO head temperatures, it can be seen that there was no significant difference in temperature between the fuels at $-20^{\circ} \mathrm{F}$. At $20^{\circ} \mathrm{F}$ and $0{ }^{\circ} \mathrm{F}$, the E15 fuel after 90 seconds had lower temperatures than E0. This trend correlates with the lower engine speeds in Figure 4.49 for these two tests.

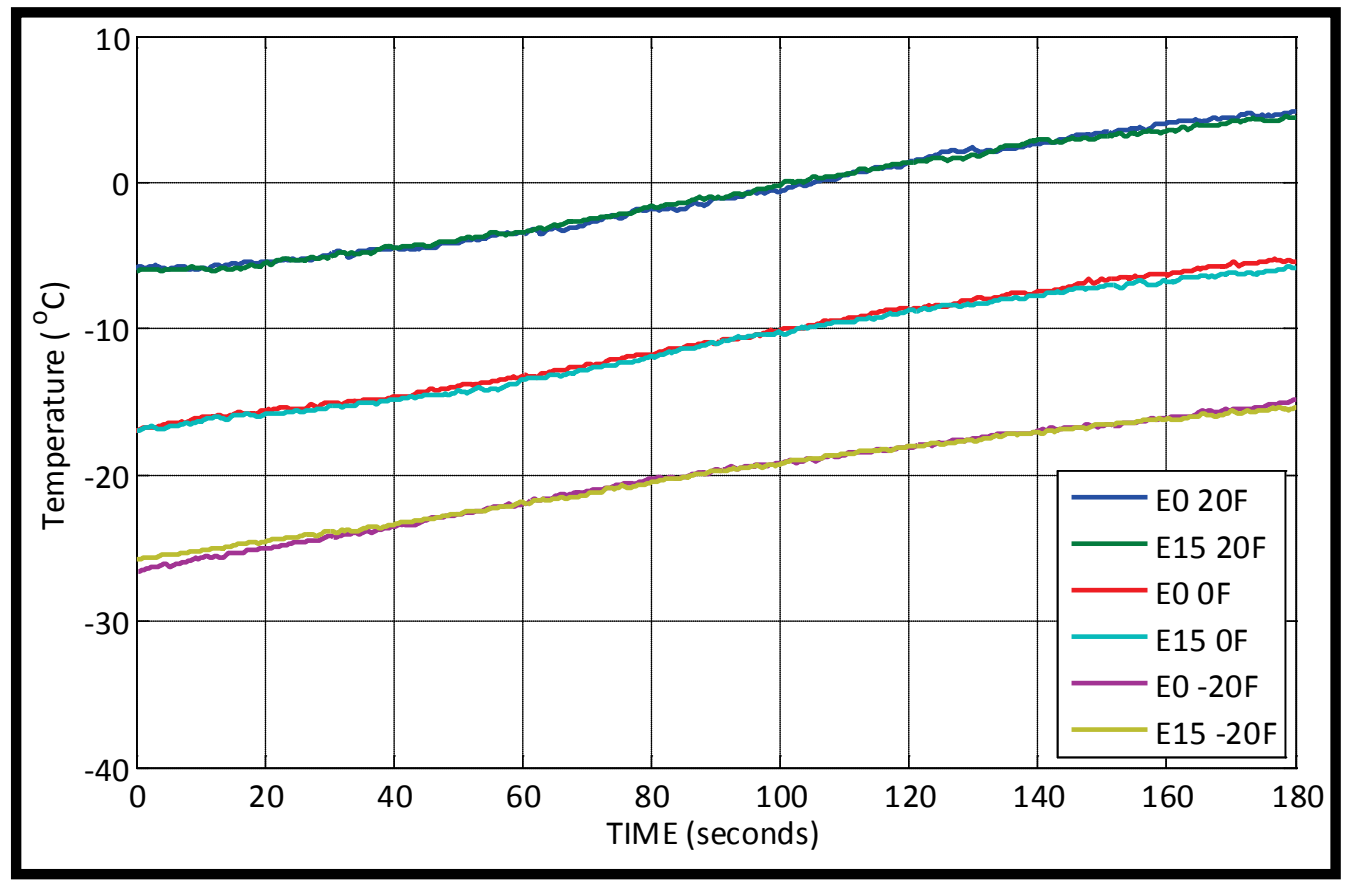

Figure 4.50: Average Arctic Cat cold-start air temperatures 


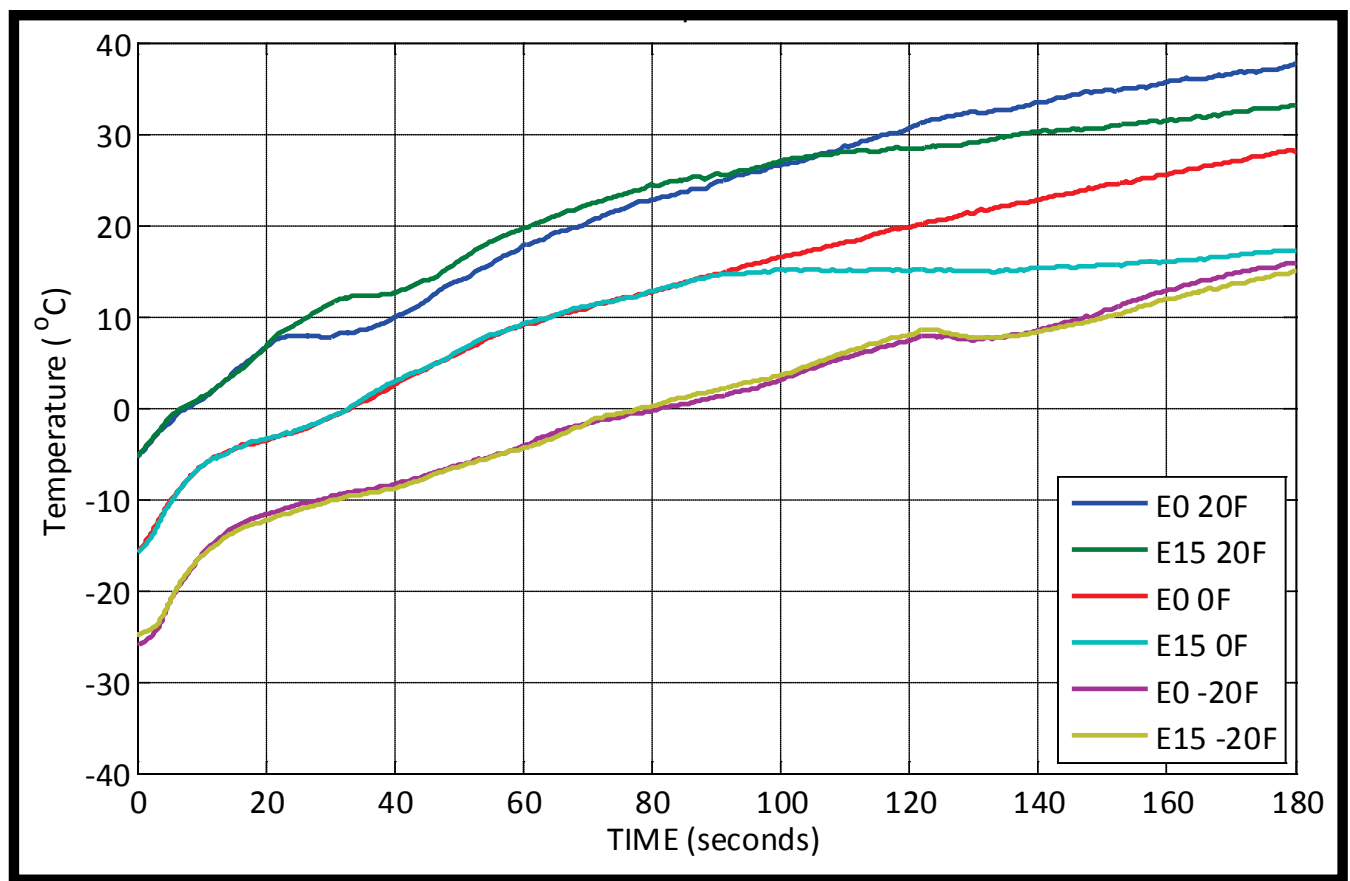

Figure 4.51: Average Arctic Cat cold-start PTO head temperatures

The following two figures, Figure 4.52 and Figure 4.53, are plots of the exhaust gas temperatures from both cylinders which large temperature differences were observed. The maximum temperatures on the PTO side were around $240{ }^{\circ} \mathrm{C}$ and on the MAG cylinder, the maximum temperature was around $180{ }^{\circ} \mathrm{C}$. One contributing factor of the temperature difference was that the cooling fan pulls air over the engine from the MAG side to the PTO side and therefore there was warmer air over the PTO side. The PTO exhaust gas temperatures initially had no difference in temperature for all tests. At $20^{\circ} \mathrm{F}$, before the choke was flipped on at 30 seconds, the E0 fuel EGT decreased earlier and more significantly than E15. After the choke was flipped on, the temperature differences decreased. At $0{ }^{\circ} \mathrm{F}$, the two fuels were similar until 90 seconds when the E15 fuel temperature decreased to values below every other test average which correlates with engine speed. At $-20^{\circ} \mathrm{F}$, there was a small difference between the two fuels until the last 20 seconds when the E15 EGT average dropped below the E0 average which correlates with engine speed. Small differences in temperature were observed for the MAG EGT. Additional plots of Arctic Cat cold-start data such as ambient pressure and relative humidity during the tests are located in Appendix A.22 to Appendix A.27. 


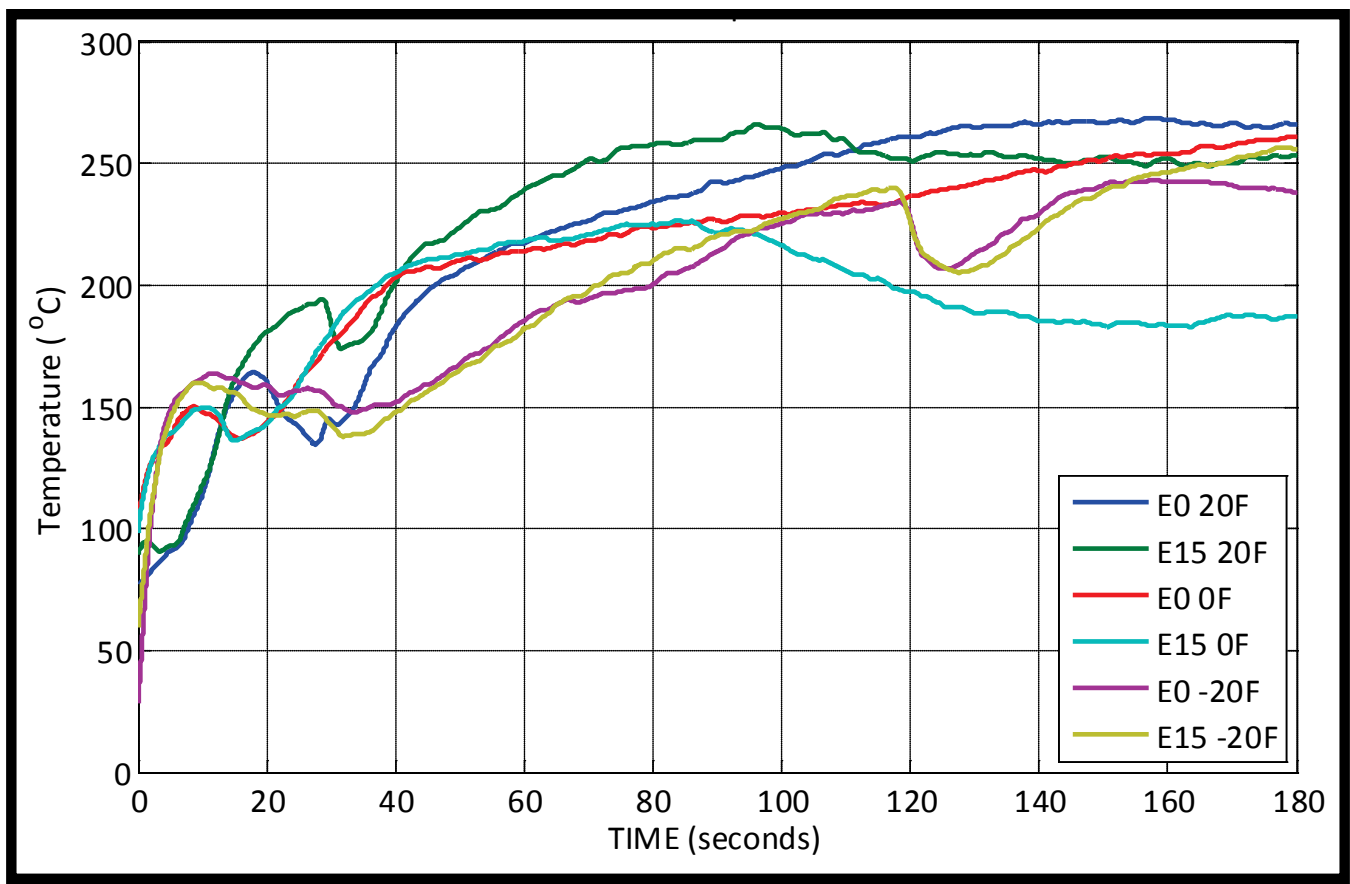

Figure 4.52: Average Arctic Cat cold-start PTO exhaust gas temperatures

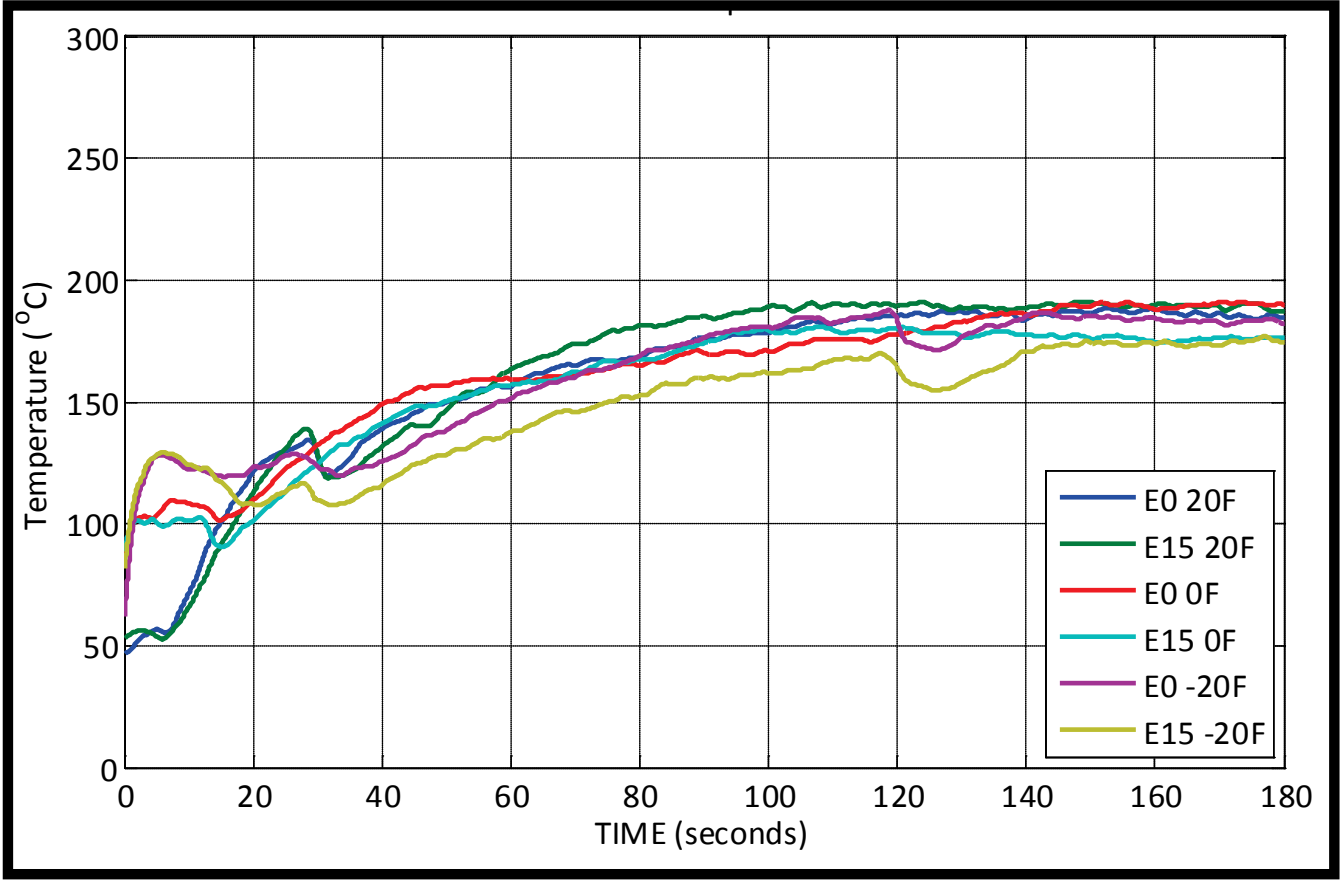

Figure 4.53: Average Arctic Cat cold-start MAG exhaust gas temperatures 


\section{Chapter 5 Conclusions and Future Work}

\subsection{Conclusions}

To investigate and analyze the effects the addition of ethanol to a fuel, cold start tests were performed. Two different fuels were used; E0 as a baseline fuel and E15 to represent a higher concentration of ethanol in fuel. Three different temperatures were used to represent a typical cold-start of a snowmobile in the middle of winter. The temperatures were $+20^{\circ} \mathrm{F}, 0{ }^{\circ} \mathrm{F}$, and $-20^{\circ} \mathrm{F}$ and were reached and maintained inside a retrofitted refrigerated trailer. Four snowmobiles from all four major manufacturers were used to represent the wide variety of technology in the snowmobile community. The snowmobiles used were a four-stroke Yamaha FX Nytro RTX, a direct injected twostroke Ski-doo MX Z TNT 600 E-TEC, a semi-direct injected two-stroke Polaris 800 Rush, and a carbureted two-stroke Arctic Cat F570. Emissions were sampled using a Semtech DS and engine data was recorded using mobile onboard EVO systems.

After much trial and error, a cold-start process that produced fairly consistent results of emissions and engine data was produced. This process could possibly be applied to other small engines.

The emissions results from the four vehicles that were tested were explained in this chapter. Trends were observed with most of the vehicles but some had more prominent differences than others. The Yamaha RX showed typical trends of increasing $\mathrm{CO}_{2}$ and decreasing $\mathrm{CO}$ and THC emissions. The engine speed showed small differences between fuels but the EGT had increased with the E15 fuel. These trends follow the typical trends of using an oxygenated fuel because of the enleanment. The Ski-doo emissions appeared to not be affected by the ambient temperature or the fuel properties. The engine speed was quite consistent and the EGTs decreased with the E15 fuel. The Ski-doo was calibrated to run very lean at idle, so when the E15 fuel was used which caused the engine to operate farther away from stoichiometry, the EGTs decreased. The Polaris emissions did not change significantly because of the use of a resistor in the wiring harness. The resistor changed the calibration of the engine to operate with an 
oxygenated fuel and therefore the operation and emissions were not changed significantly. Trends were not observed in the emissions or engine data when the fuel was changed. The Arctic Cat emissions were the hardest to obtain because of consistency. Few trends were observed between the two fuels. Therefore no obvious trends of increasing or decreasing of emissions was observed.

Overall trends of the emissions align with results from previous published data. The engines that were operating rich of stoichiometry showed trends of increasing EGTs with decreasing $\mathrm{CO}$ emissions. The Ski-doo which was operating lean of stoichiometry, EGTs decreased with no noticeable trends in emissions. The four-stroke engine behaved as previously documented four-stroke engines with the same trends. The majority three two-stroke engines in this cold-start testing did not show consistent trends of emissions or engine parameters.

\subsection{Future Work}

This cold-start testing performed on snowmobiles was part of a larger project in which ethanol in the fuel was observed in all facets of snowmobiling. The other parts of the testing involved subjective/objective handling, straight-line acceleration, on-snow emissions, and durability testing. All of this testing was done with E0 and E15. When all of this testing is complete, a final report will be submitted to NREL who funded this project.

While looking at the results from this testing, there are a few things that could be tested in the future. The first thing that could be done would be to take the Polaris 800 Rush and Arctic Cat F570 and repeat all of these tests at the same temperatures using the same fuels but using a FID analyzer that is capable of measuring up to $100000 \mathrm{ppmC} 1$ or higher of THC. This way, hydarocarbon data could be recorded for the snowmobiles and then more of the questions about emissions could be expalained using the hydrocarbon data. 
Other testing that would be interesting and possibly useful would be to use a different form of choke procedure on the Arctic Cat to be able to see if other information could be gained from a carburated engine. These coldstart tests could also be performed on other engines that are carburated such as snowblowers or lawnmowers. There is not a lot of information on recreational or utility engines using ethanol in the fuel and if the volume of ethanol increases in fuel it would be good to have an idea on what will happen to these engines.

In some locations where snowmobiles are used, the temperatures can drop below the $-20^{\circ} \mathrm{F}$ that the snowmobiles were tested at so it could be useful to modify or build a test cell that can maintain a colder temperatures and test at these temperatures. As the temperature drops farther and farther, the engines will become harder to start, and the ethanol in the fuel could become more of a factor than it did at these concentrations and temperatures.

Additional work in the area of ethanol fuels would also be valuable. If these snowmobiles could be used to increase the ethanol content to 20 or 30 percent, and test the cold-startability of the engines would be very valuable to find a maximum limit of ethanol.

To bring more consistency into the testing and procedures, a pulling device could be designed. This would produce more concistent results as the pulling forces would be the same when comparing different fuels or temperatures. 


\section{Bibliography}

AIM Racing Data [Internet]. 2011. Milano (Italy): AIM Racing Data Power. PowerCar Products: EVO3; [updated 2011, cited 2012 Apr 11]. Available from: http:/www.aimsportline.com/pages/car/section_car_evo3.htm

AIM Sports [Internet]. 2006. Milano (Italy): AIM Sports, LLC. Images for Download Product Photos and Logos; [updated 2006, cited 2012 Apr 1]. Available from: http://www.aimsports.com/news/images.html

Bresenham Damon, Reisel John. 1999. The Effect of High Ethanol Blends on Emissions from Small Utility Engines. SAE Paper 1999-01-3345

Bresenham Damon, Reisel John. 1998. Spindt Air-Fuel Ratio Method Generalization for Oxygenated Fuels. SAE Paper 982054

Cabustion [Internet]. 2008. Cambridge (United Kingdom): Cambustion. Fast FID Principles; [updated 2008 Jun 4, cited 2012 Apr 11]. Available from: http://www.cambustion.com/products/hfr500/fast-fid-principles

Cabustion [Internet]. 2008. Cambridge (United Kingdom): Cambustion. Operating Principle Nondispersive Infrared Detector (NDIR); [updated 2008 Jun 4, cited 2012 Apr 11]. Available from: http://www.cambustion.com/products/ndir500/operating-principle Colpin C, Leone T, Lhuillery M, Marchal A. 2009. Key Parameters for Startability Improvement Applied to Ethanol Engines. SAE Paper 2009-01-0616

Emission Test Cycles [Internet]. 2006. Dieselnet. California Unified Cycle; [updated 2006 Nov, cited 2012 Apr 1]. Available from: http://www.dieselnet.com/standards/cycles/uc.php 
Fuel-Testers [Internet]. 2009. MLR Solutions. Ethanol Fuel History; [updated 2009 Mar, cited 2012 Apr 11]. Available from: http://www.fueltesters.com/ethanol_fuel_history.html

Heywood John. 1988. Internal Combustion Engine Fundamentals. $1^{\text {st }}$ ed. New York: McGraw-Hill.

H.R. 6 (110th) [Internet]. 2007. Civic Impulse, LLC. Energy Independence and Security Act of 2007; [updated 2007, cited 2012 Apr 11]. Available from:

http://www.govtrack.us/congress/bills/110/hr6

Knoll Keith, West Brian, Huff Shean, Thomas John, Orban John, Cooper Cynthia. 2009. Effects of Mid-Level Ethanol Blends on Conventional Vehicle Emissions. SAE Paper 2009-01-2723

Manekar Abhishek. 2010. Development of Temperature Controlled Vehicle Test Facility for Sub-Ambient Cold Start Tests on Engines Using Ethanol and Gasoline. Houghton (MI): Michigan Technological University.

SAE Standards. 1998. SAE Cold Start and Driveability Procedure. SAE Standard J1635

Semtech-DS: Gaseous Portable Emissions Measurement System [Internet]. 2011. Saline (MI): Sensors Inc. Semtech DS; [updated 2011 Mar, cited 2012 Apr 11]. Available from: http://www.sensors-inc.com/ds.html

Tsunooka Takashi, Hosokawa Yohei, Utsumi Shintaro, Kawai Takashi, Sonoda Yukihiro. 2007. High Concentration Ethanol Effect on SI Engine Cold Startability. SAE Paper 2007-01-2036

U.S. Energy Information Administration [Internet]. 2011. Washington (DC): U.S. Department of Energy. Annual Energy Review; [updated 2012 Mar 15, cited 2012 Apr 11]. Available from: http://205.254.135.24/totalenergy/data/annual/ 
Wright Christopher W, White, Jeff J. 1998. Development and Validation of a Snowmobile Engine Emission Test Procedure. SAE Paper 982017 


\section{Appendix A}

\section{A.1 Note sheet and additional plots}

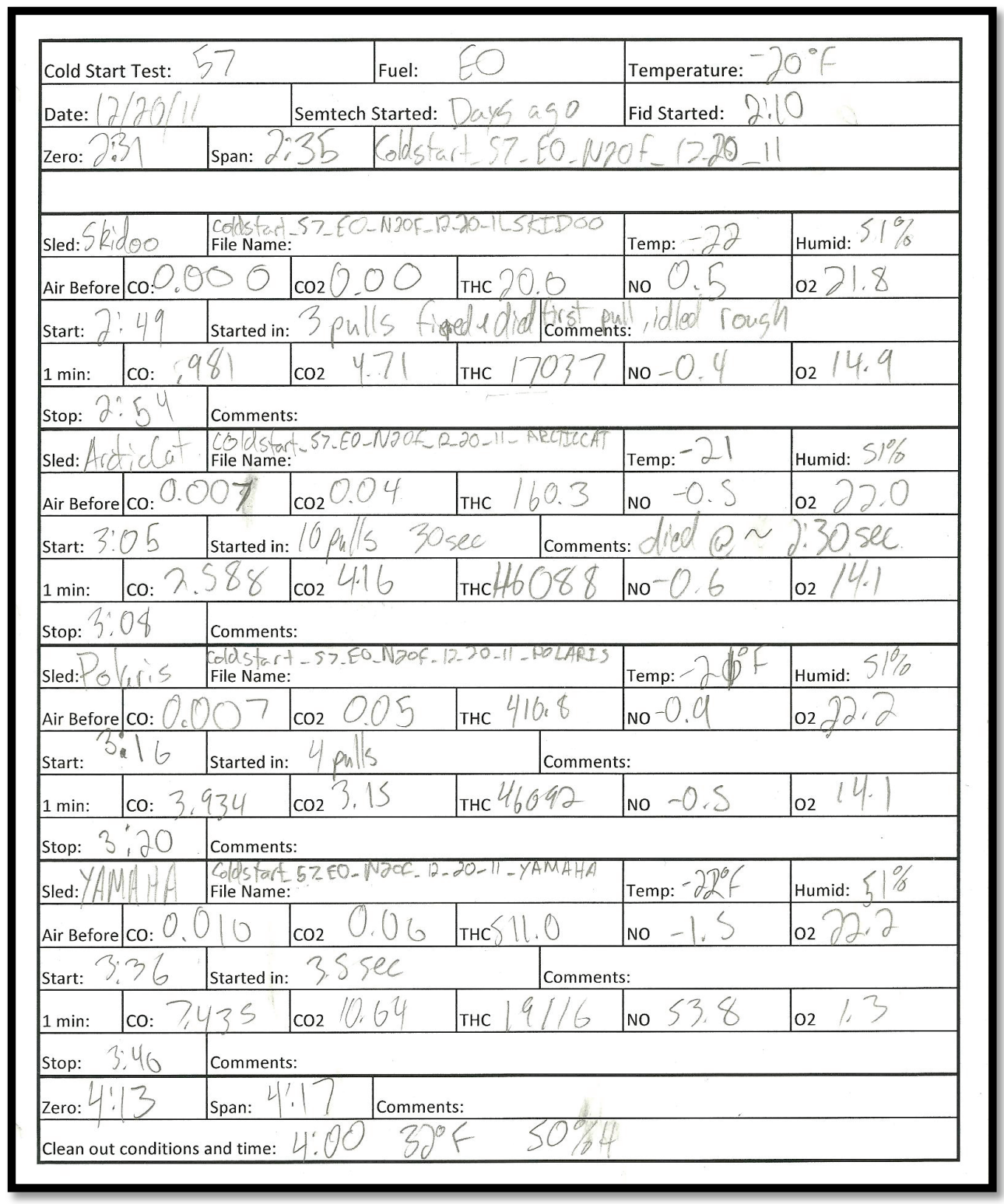

Figure A.1: Sample note sheet from cold-start testing 


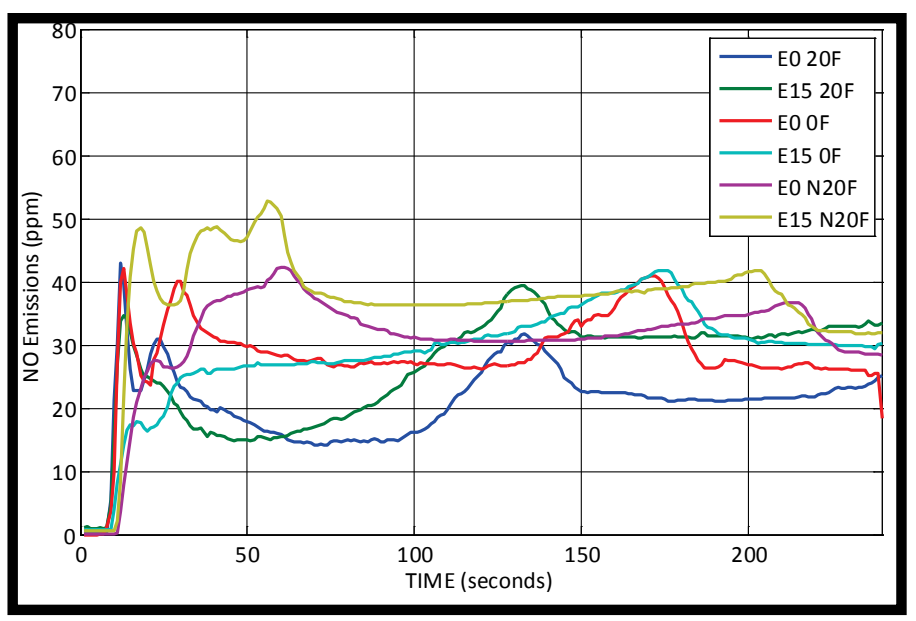

Figure A.2: Average Yamaha cold-start NO emissions

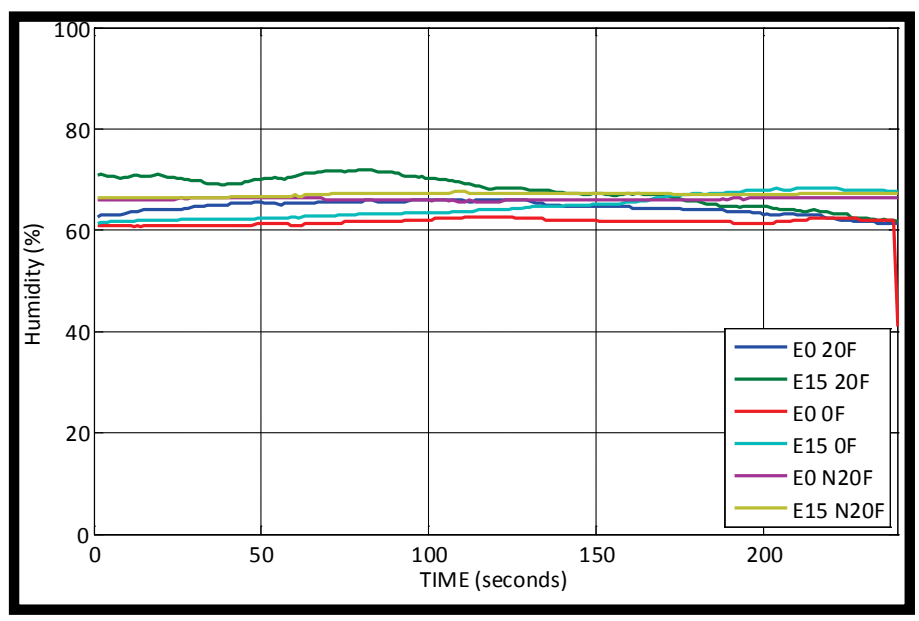

Figure A.3: Average Yamaha cold-start relative humidity

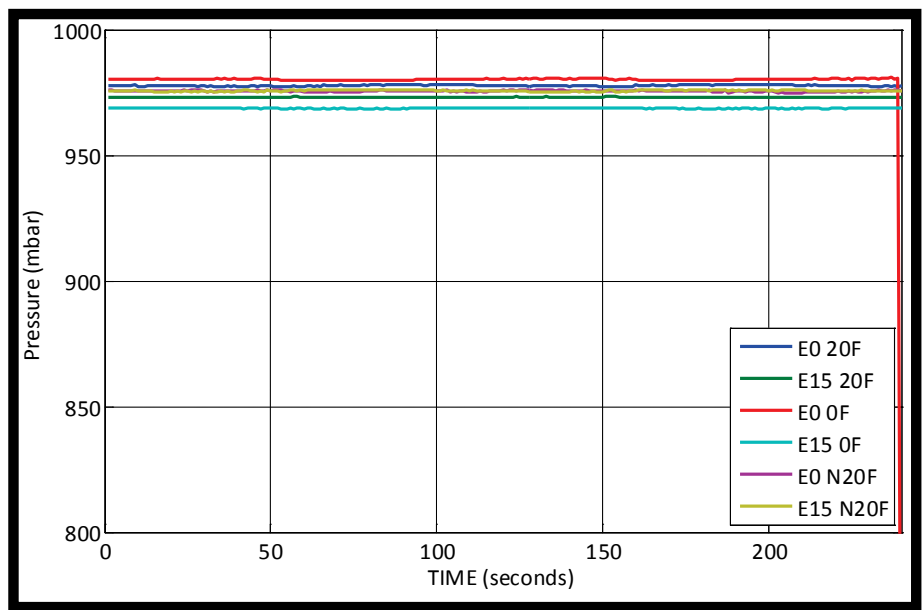

Figure A.4: Average Yamaha cold-start ambient pressures 


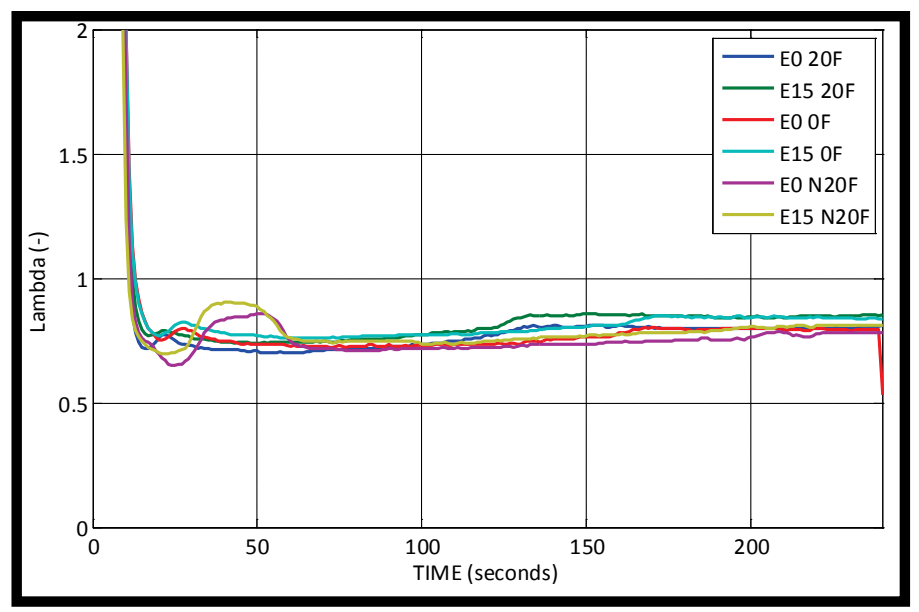

Figure A.5: Average Yamaha cold-start lambda

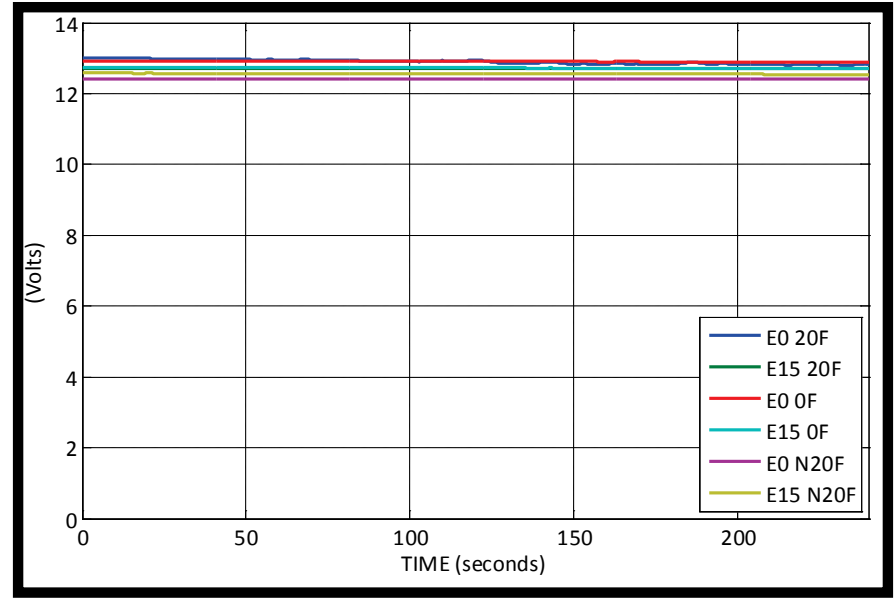

Figure A.6: Average Yamaha cold-start DAQ system battery voltage

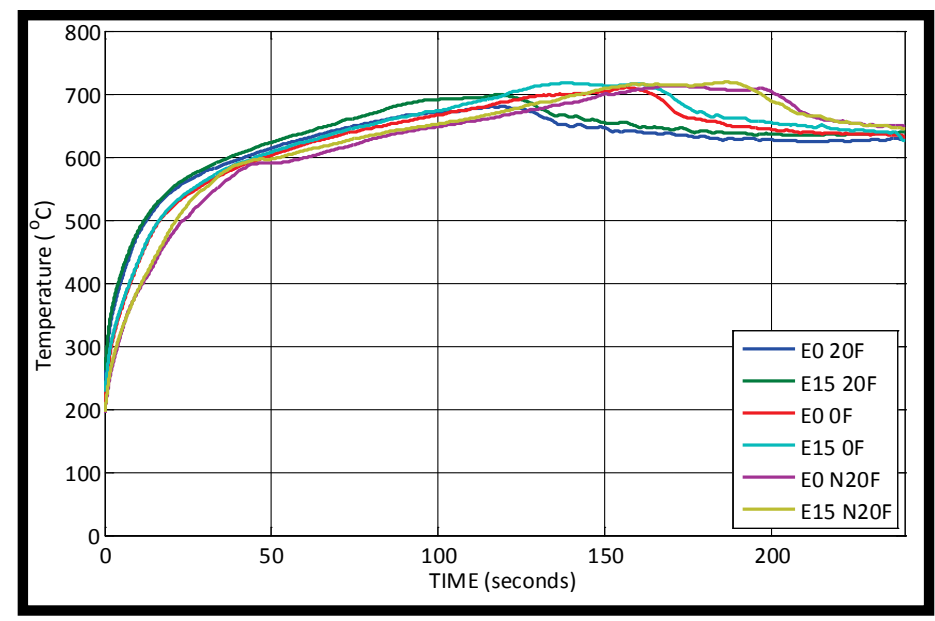

Figure A.7: Average Yamaha cold-start MAG exhaust gas temperatures 


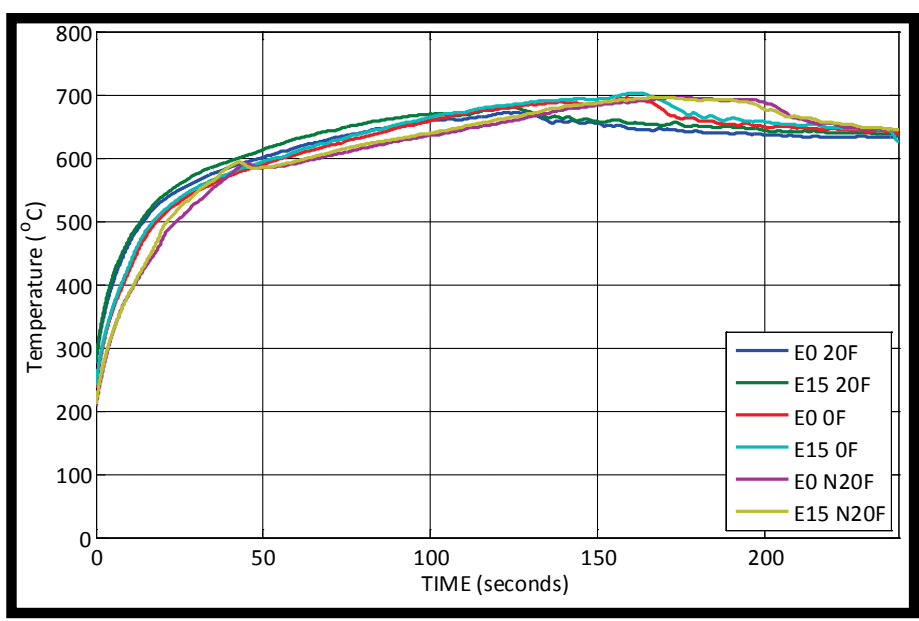

Figure A.8: Average Yamaha cold-start PTO exhaust gas temperatures

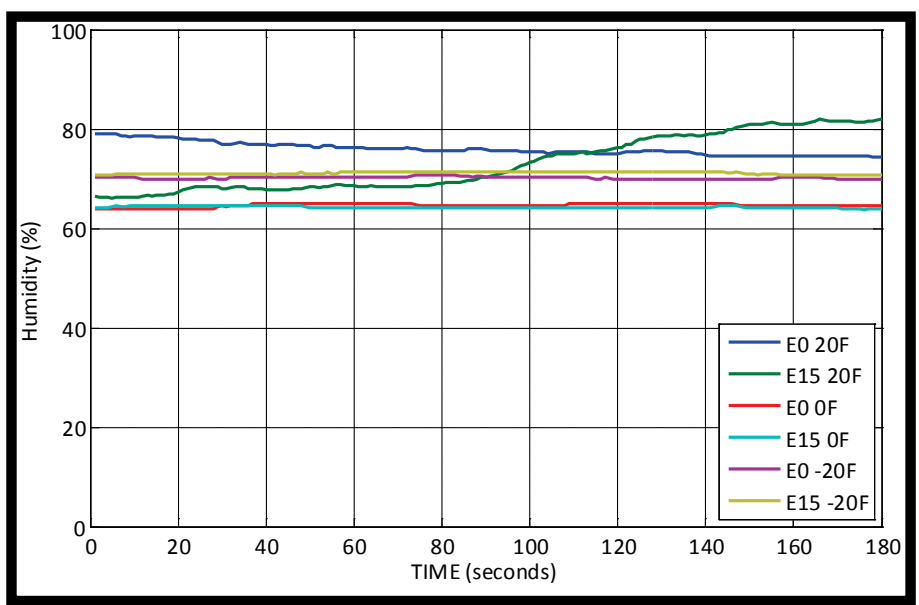

Figure A.9: Average Ski-doo cold-start relative humidity

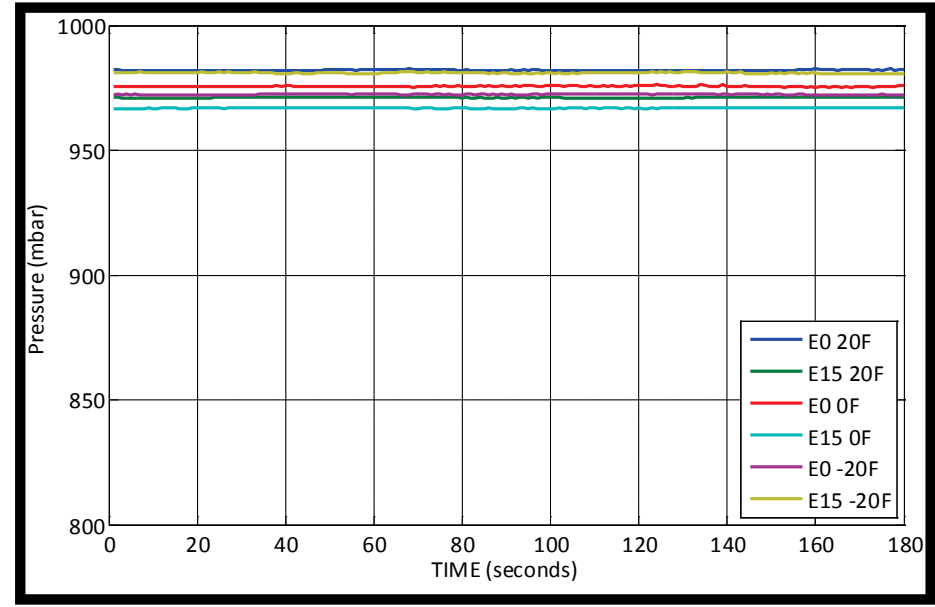

Figure A.10: Average Ski-doo cold-start ambient pressures 


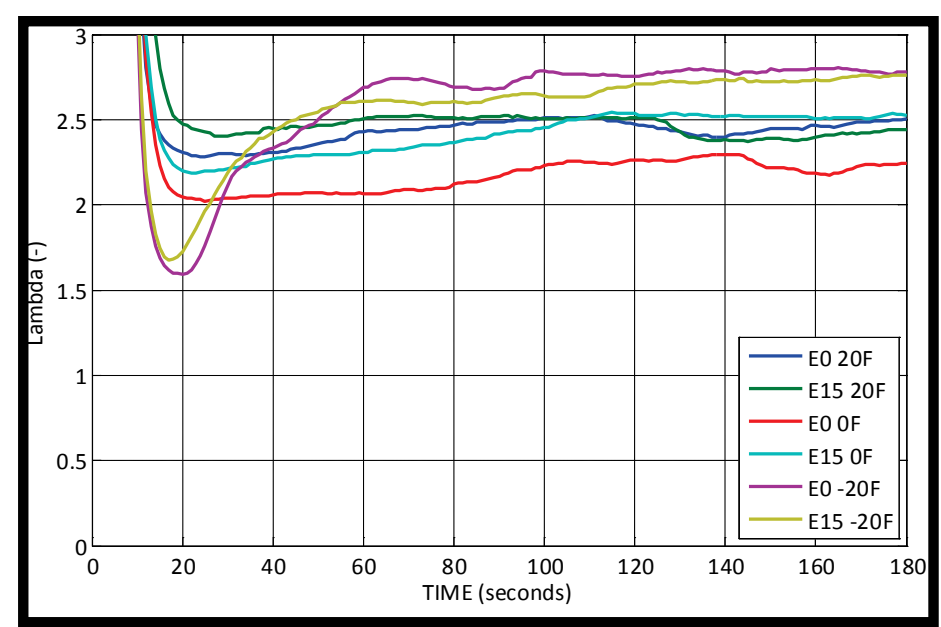

Figure A.11: Average Ski-doo cold-start lambda

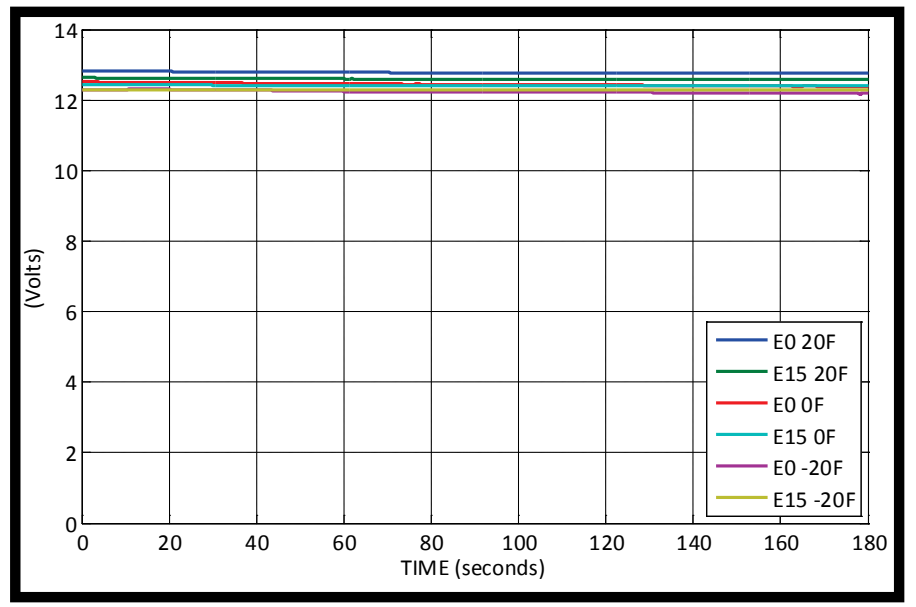

Figure A.12: Average Ski-doo cold-start DAQ battery voltages

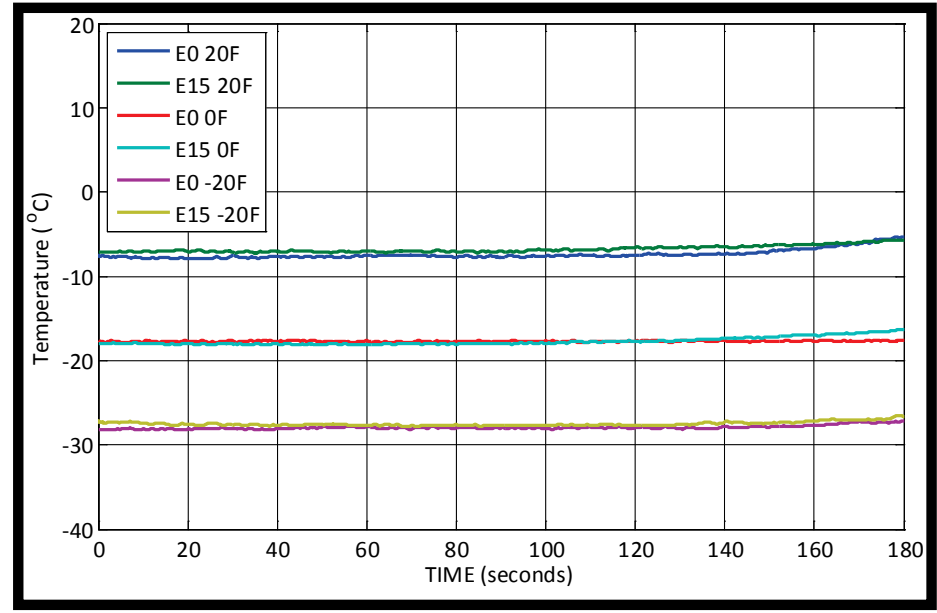

Figure A.13: Average Ski-doo cold-start cold engine coolant temperatures 


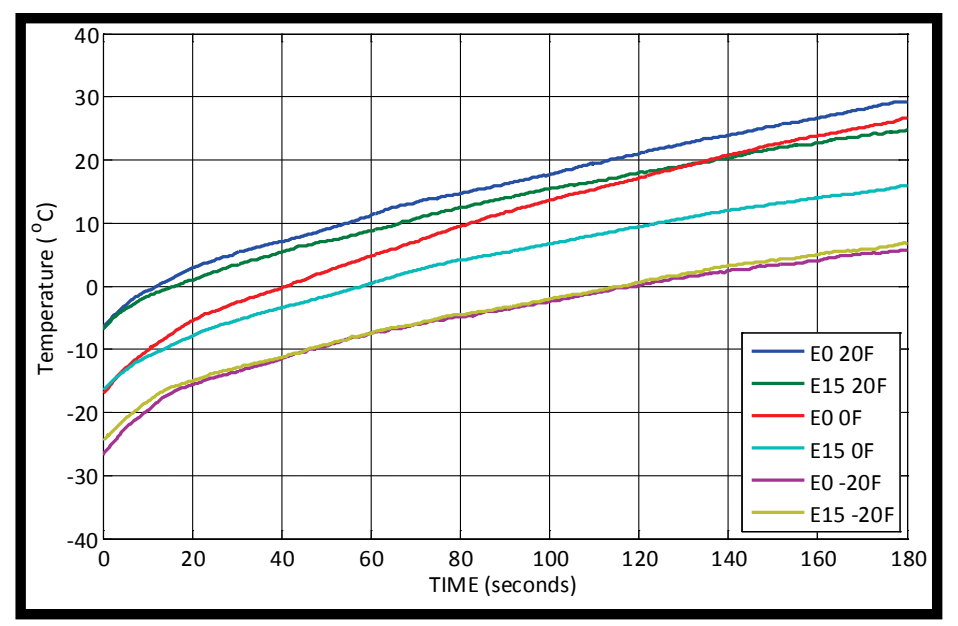

Figure A.14: Average Ski-doo cold-start PTO head temperatures

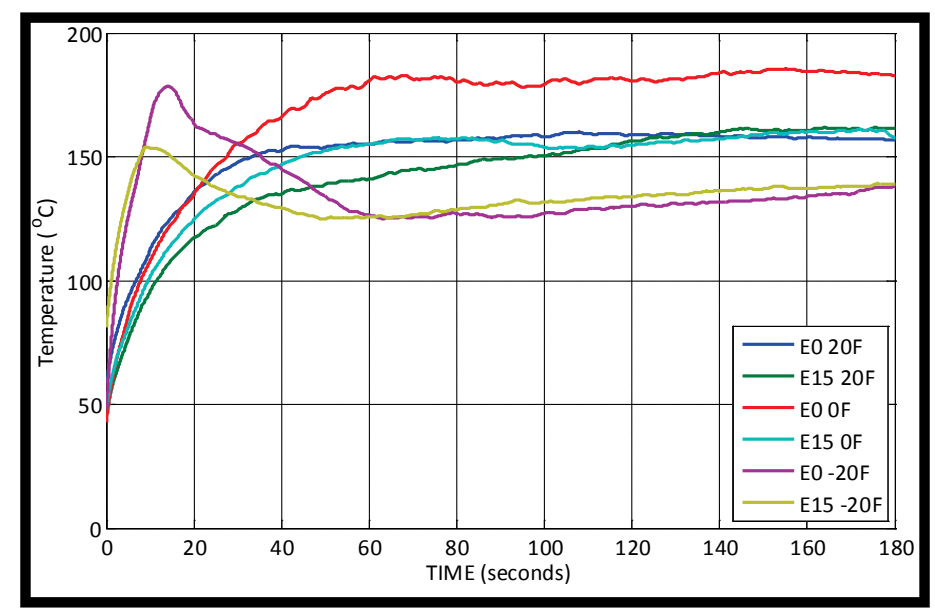

Figure A.15: Average Ski-doo cold-start PTO exhaust gas temperatures

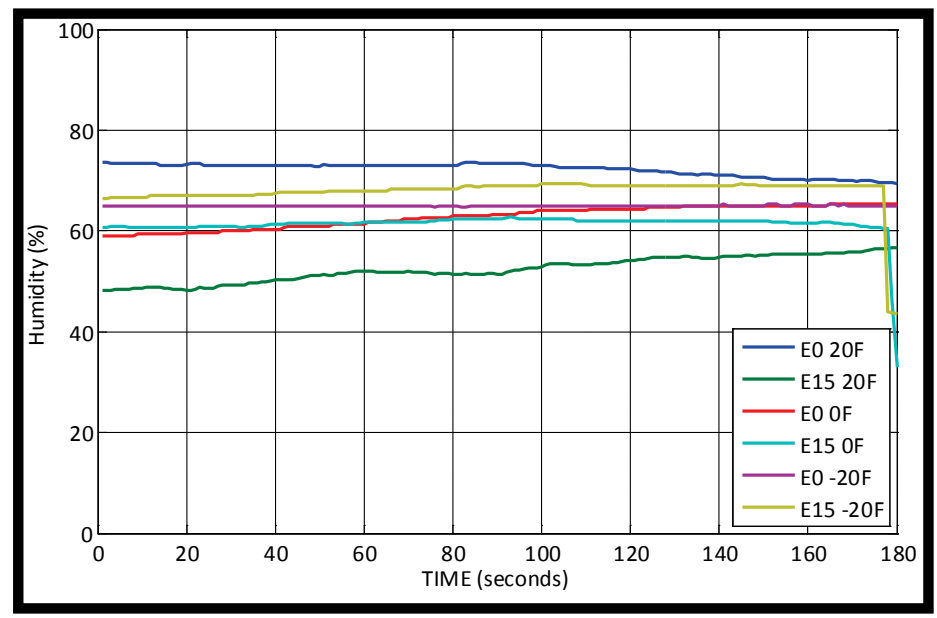

Figure A.16: Average Polaris cold-start relative humidity 


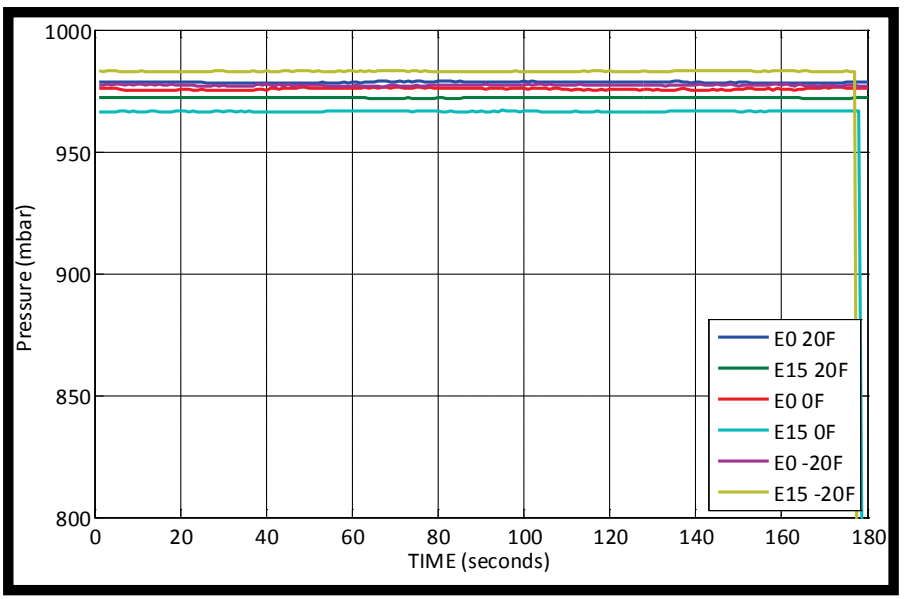

Figure A.17: Average Polaris cold-start ambient pressures

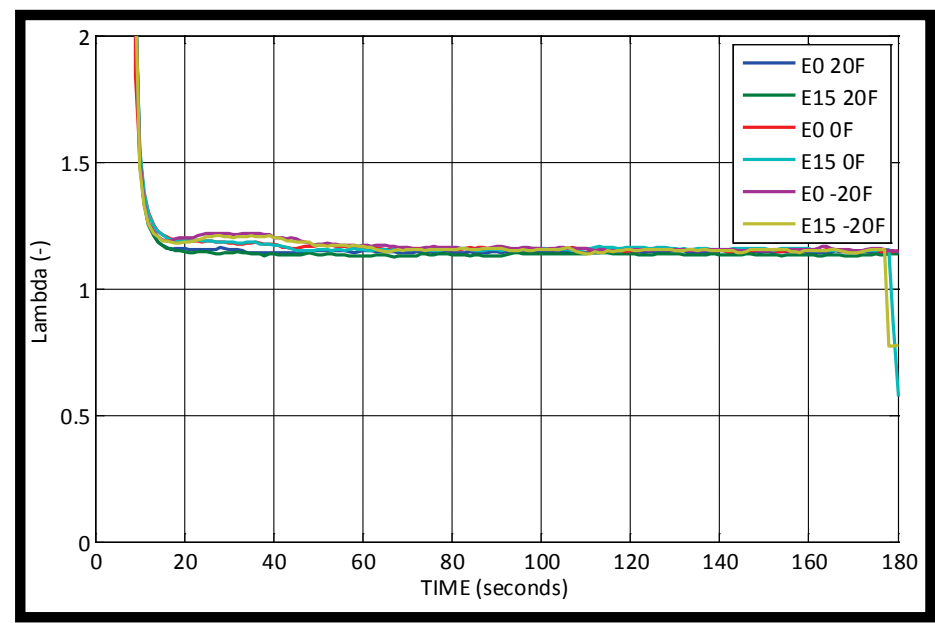

Figure A.18: Average Polaris cold-start Lambda

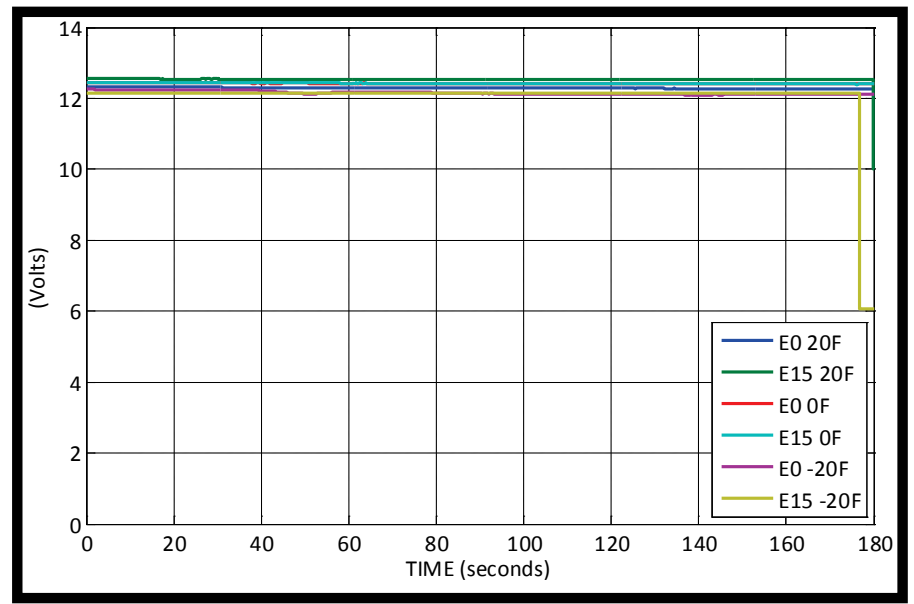

Figure A.19: Average Polaris cold-start DAQ battery voltages 


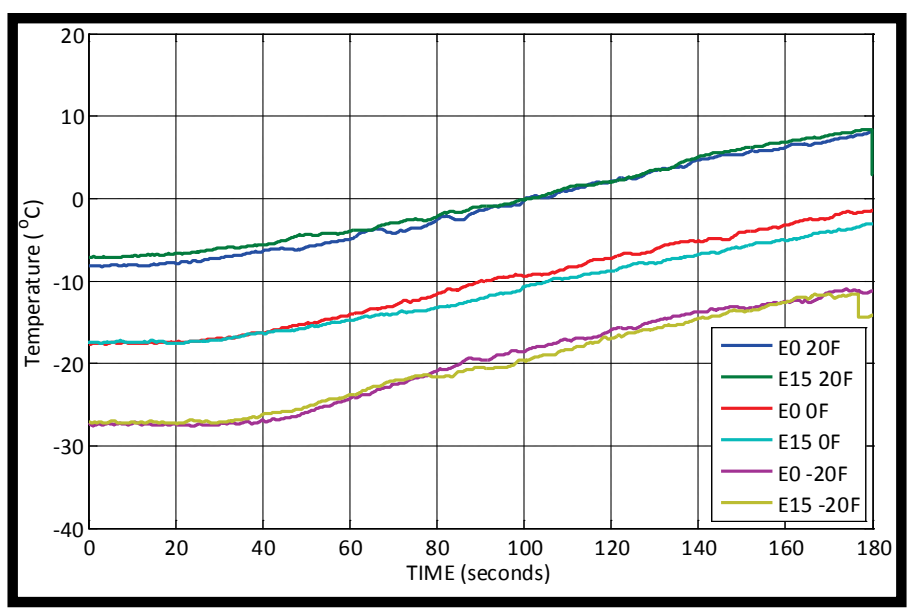

Figure A.20: Average Polaris cold-start engine coolant cold temperatures

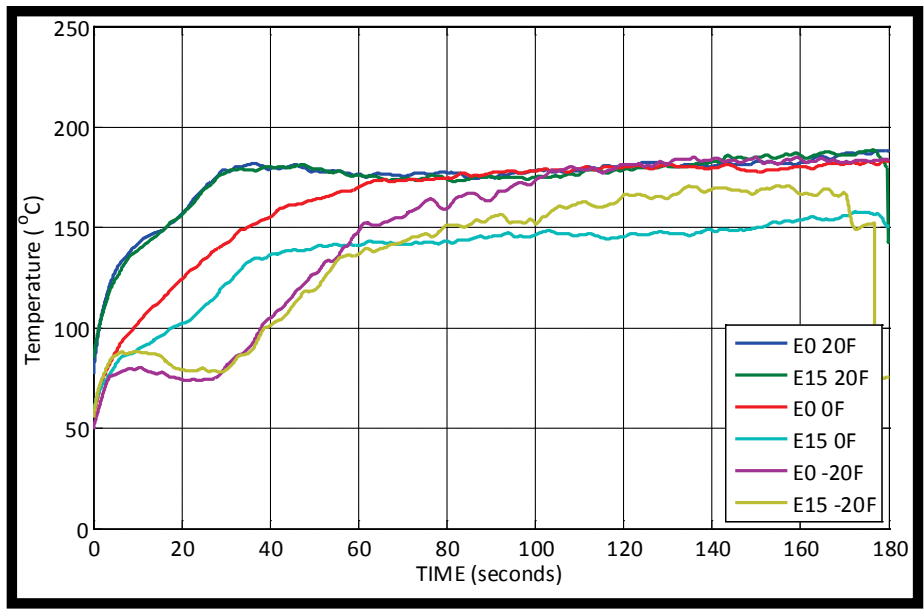

Figure A.21: Average Polaris cold-start PTO exhaust gas temperatures

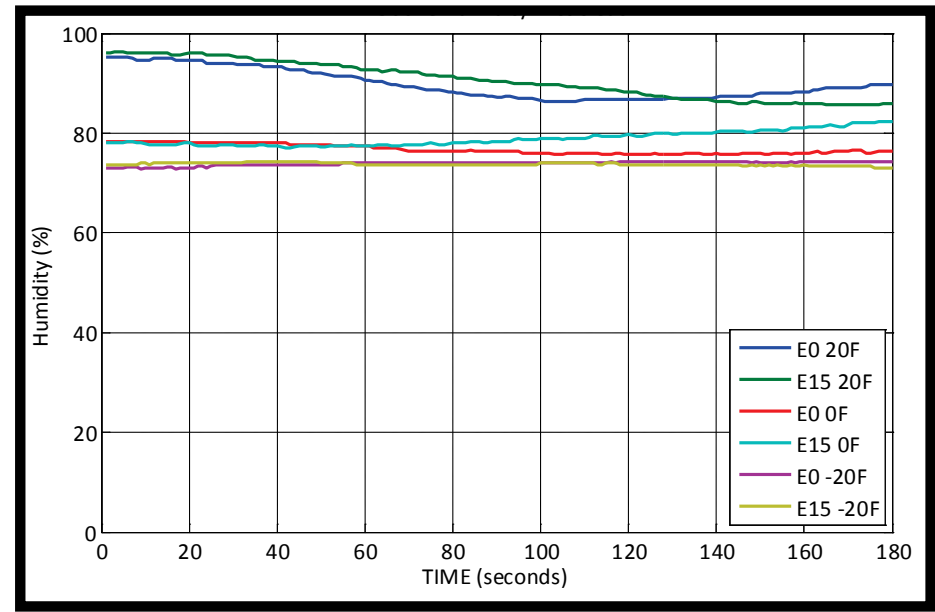

Figure A.22: Average Arctic Cat cold-start relative humidity 


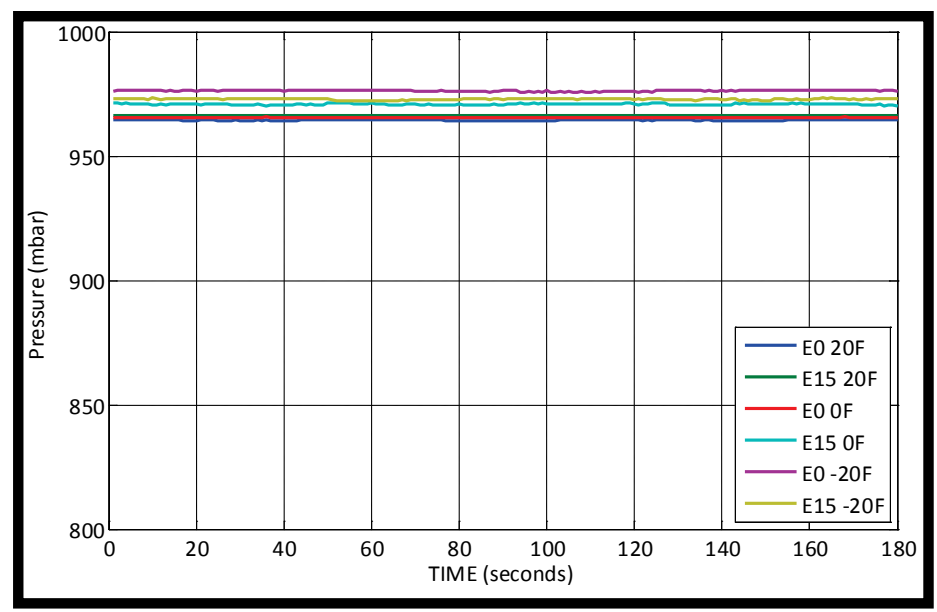

Figure A.23: Average Arctic Cat cold-start ambient pressures

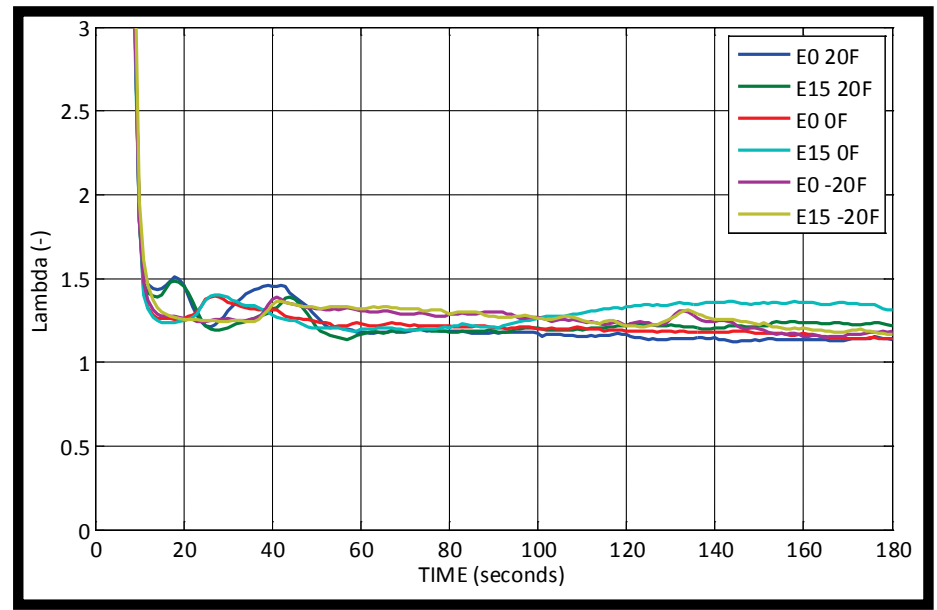

Figure A.24: Average Arctic Cat cold-start lambda

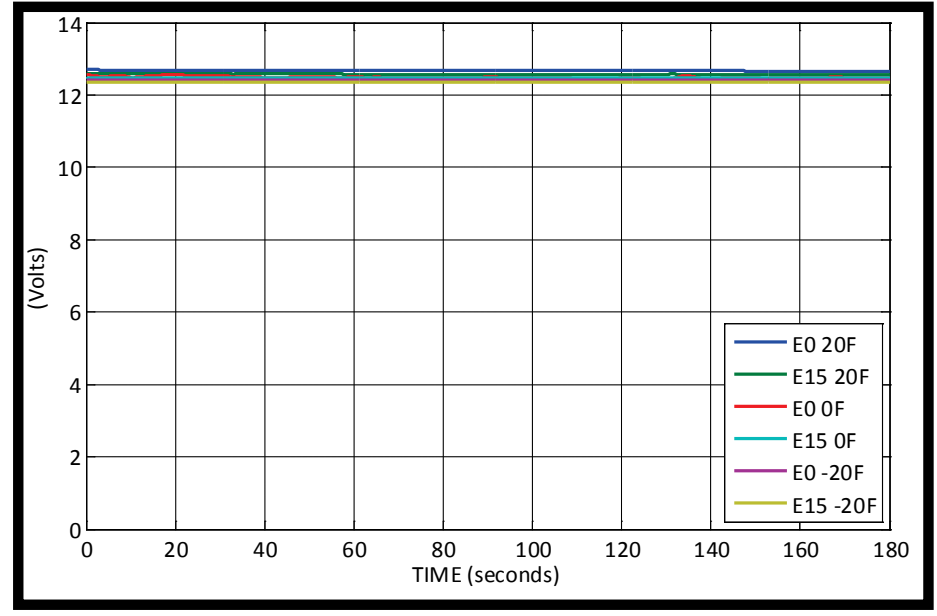

Figure A.25: Average Arctic Cat cold-start DAQ system battery voltages 


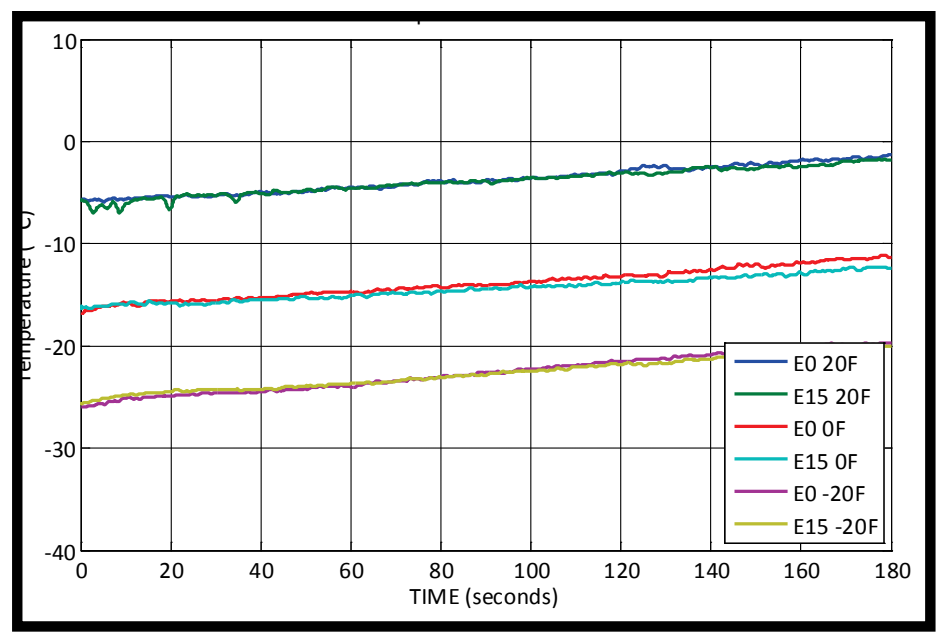

Figure A.26: Average Arctic Cat cold-start fan air temperature in

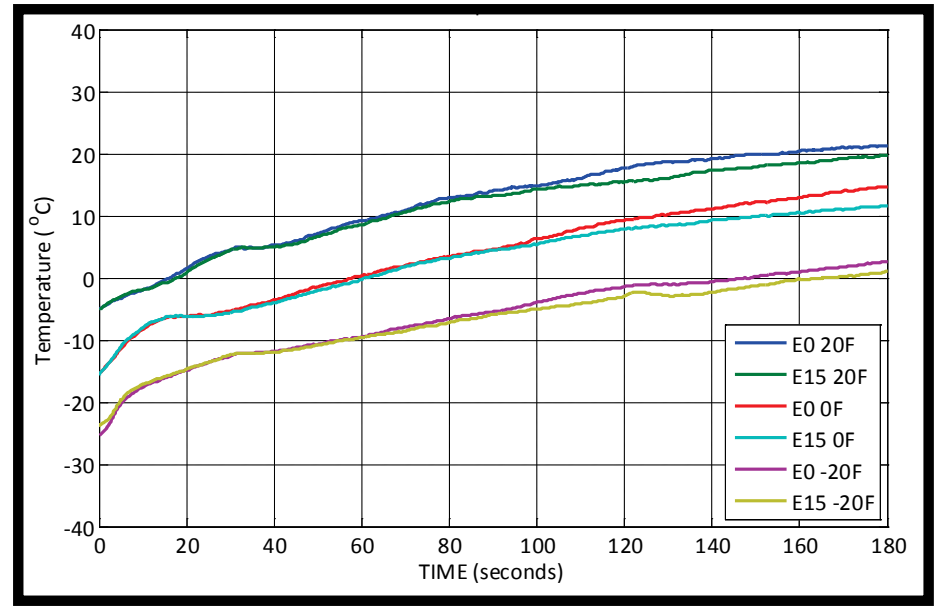

Figure A.27: Average Arctic Cat cold-start MAG head temperatures 


\section{A.2 Permissions}

Below is an email received from the SAE Copyright office which applies to Figure 2.1.

Dear Mike, Thank you for contacting SAE for permission to reprint figure 10 from SAE paper 2009-01-2723 in your Masters thesis titled: "Cold-Start Emissions Testing on Snowmobiles using Gasoline and Ethanol" for Michigan Technological University.

SAE does not hold the copyright on this paper. This paper was the work of the U.S. Government and is not subject to copyright protection in the United States. Therefore, you may use this information without SAE permission, and we request you include the following reference below the figure:

"Reprinted from SAE paper 2009-01-2723"

You should also reference the paper title and authors in the reference section of your thesis.

Again, thank you for contacting SAE for this permission.

Best regards,

Terri Kelly

Intellectual Property Rights Administrator

SAE International | 400 Commonwealth Drive | Warrendale, PA 15096-0001 | USA

Office: $+01 \underline{\text { 724-772-4095 }}$ | Fax: +01 724-776-9765 terri@sae.org | www.sae.org 